Water-Quality Data and Descriptions of Biota for Selected Watersheds of the Limited Use Area, Vernon Ranger District, Kisatchie National Forest, Louisiana, September 1996 through March 1997

By Roland W. Tollett and Robert B. Fendick, Jr.

U.S. GEOLOGICAL SURVEY

Open-File Report 98-163

Prepared in cooperation with the U.S. ARMY JOINT READINESS TRAINING CENTER AND FORT POLK 


\section{U.S. DEPARTMENT OF THE INTERIOR \\ BRUCE BABBITT, Secretary}

U.S. GEOLOGICAL SURVEY

Thomas J. Casadevall, Acting Director

The use of trade, product, industry, or firm names in this report is for descriptive or location purposes only and does not constitute endorsement of products by the U.S. Government nor impute responsibility for any present or potential effects on the natural resources.

For additional information contact:

District Chief

U.S. Geological Survey 3535 S. Sherwood Forest Blvd., Suite 120

Baton Rouge, LA 70816

E-mail: dc_la@usgs.gov

Telephone: (504) 389-0281

Fax: (504) 389-0706
Copies of this report can be purchased from:

U.S. Geological Survey

Branch of Information Services

Box 25286

Federal Center

Denver, CO 80225-0286 


\section{CONTENTS}

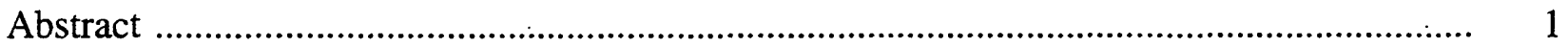

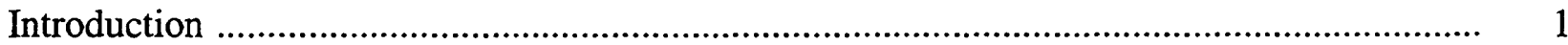

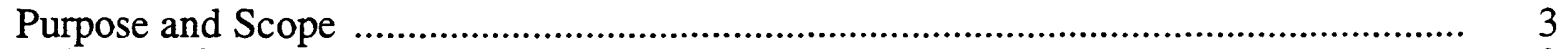

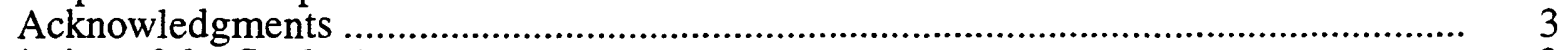

Description of the Study Area ........................................................................................

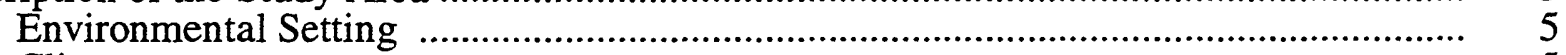

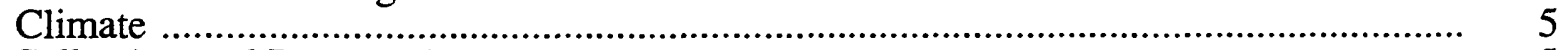

Data Collection and Presentation .................................................................................... 5

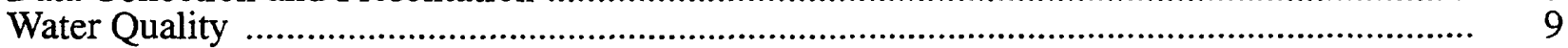

Reaches of Louisiana Scenic Rivers .........................................................................

Areal Stream Coverage .......................................................................................... 13

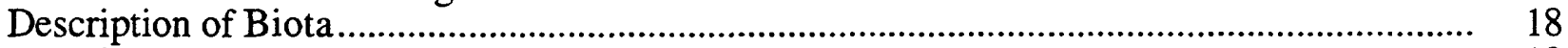

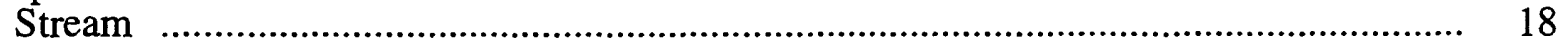

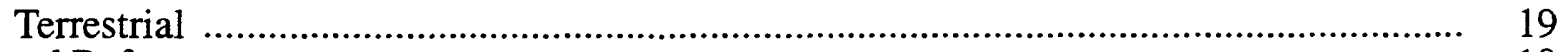

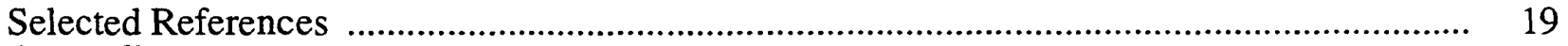

Appendices:

Appendix A: Periphyton analyses for samples collected from sites in the Limited Use

Area, Vernon Ranger District, Kisatchie National Forest, Louisiana, by Fred Bryan ........

Appendix B: Analyses of freshwater mussels in the Limited Use Area, Vernon Ranger

District, Kisatchie National Forest, Louisiana, by Malcolm F. Vidrine..

Appendix C: Botanical summary of the Limited Use Area, Vernon Ranger District,

Kisatchie National Forest, Louisiana, by Charles M. Allen

\section{FIGURES}

1. Map showing Fort Polk Military Reservation and the Limited Use Area of the Kisatchie National Forest, Vernon Ranger District, Vernon Parish,

Louisiana.

2. Map showing location of the study area, basin divides, sampling sites, and bogs within the Fort Polk Military Reservation and Limited Use Area boundaries, Vernon Parish, Louisiana

3. Map showing updip limits of hydrogeologic units of Miocene age and younger deposits in Vernon Parish and the Limited Use Area, Vernon Ranger District, Kisatchie National Forest, Louisiana

4. Diagram showing stratigraphic and hydrogeologic units outcropping in Vernon Parish, Louisiana, and the study area

5. Graph showing specific conductance values and rainfall, November 5, 1996 February 18, 1997, for the daily sampling sites in the Limited Use Area,

Vernon Ranger District, Kisatchie National Forest, Louisiana

6. Graph showing values for $\mathrm{pH}$ and rainfall, November 5, 1996 - February 18, 1997, for the daily sampling sites in the Limited Use Area, Vernon Ranger District, Kisatchie National Forest, Louisiana.

7. Graph showing temperatures and rainfall, November 5, 1996 - February 18, 1997, for the daily sampling sites in the Limited Use Area, Vernon Ranger District, Kisatchie National Forest, Louisiana.

8. Graph showing calcium data for the daily sampling sites in the Limited Use Area, Vernon Ranger District, Kisatchie National Forest, Louisiana.

Graph showing magnesium data for the daily sampling sites in the Limited

Use Area, Vernon Ranger District, Kisatchie National Forest, Louisiana. 
10. Piper diagram plotting major ion data for the daily sampling sites in the Limited Use Area, Vernon Ranger District, Kisatchie National Forest,

Louisiana, October 22, 1996

11. Piper diagram plotting major ion data for the daily sampling sites in the

Limited Use Area, Vernon Ranger District, Kisatchie National Forest,

Louisiana, November 5, 1996.

12-25. Stream characterization forms:

12. Site 1 in the Limited Use Area, Vernon Ranger District, Kisatchie National Forest, Louisiana

13. Site 2 in the Limited Use Area, Vernon Ranger District, Kisatchie National Forest, Louisiana

14. Site 3 in the Limited Use Area, Vernon Ranger District, Kisatchie National Forest, Louisiana

15. Site 4 in the Limited Use Area, Vernon Ranger District, Kisatchie National Forest, Louisiana

16. Site 5 in the Limited Use Area, Vernon Ranger District, Kisatchie National Forest, Louisiana

17. Site 6 in the Limited Use Area, Vernon Ranger District, Kisatchie National Forest, Louisiana

18. Site 7 in the Limited Use Area, Vernon Ranger District, Kisatchie National Forest, Louisiana

19. Site 8 in the Limited Use Area, Vernon Ranger District, Kisatchie National Forest, Louisiana

20. Site 9 in the Limited Use Area, Vernon Ranger District, Kisatchie National Forest, Louisiana

21. Site 10 in the Limited Use Area, Vernon Ranger District, Kisatchie National Forest, Louisiana

22. Site 11 in the Limited Use Area, Vernon Ranger District, Kisatchie National Forest, Louisiana

23. Site 12 in the Limited Use Area, Vernon Ranger District, Kisatchie National Forest, Louisiana

24. Site 13 in the Limited Use Area, Vernon Ranger District, Kisatchie National Forest, Louisiana

25. Site 14 in the Limited Use Area, Vernon Ranger District, Kisatchie National Forest, Louisiana

\section{TABLES}

1. Reference list of sampling site number, latitude and longitude, and location, Vernon Parish, Louisiana

2. Basin areas, lengths, elevations, and gradients for Bundick Creek, Drakes Creek, Whiskey Chitto Creek, Birds Creek, Little Sixmile Creek, and West and East Fork of Sixmile Creek in the Vernon Ranger District, Kisatchie National Forest, Louisiana

3. Map symbol, name, and description of soils within the Limited Use Area, Vernon Ranger District, Kisatchie National Forest, Louisiana

4. Soil types within watersheds of streams north of the southern boundary of the Limited Use Area, Vernon Ranger District, Kisatchie National Forest, Louisiana 
5. Whiskey Chitto Creek (site 6) in the Limited Use Area, Vernon Ranger District, Kisatchie National Forest, Louisiana,

A. daily specific conductance data, November 1996 to February 1997 ................. 73

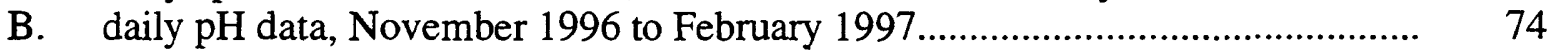

C. daily water temperature data, November 1996 to February 1997 ..................... 75

6. Birds Creek (site 9) in the Limited Use Area, Vernon Ranger District,

Kisatchie National Forest, Louisiana,

A. daily specific conductance data, November 1996 to February $1997 \ldots \ldots \ldots \ldots \ldots . . . . . . . . . .76$

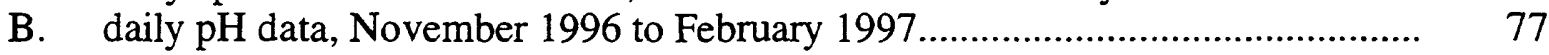

C. daily water temperature data, November 1996 to February 1997 ..................... 78

7. Whiskey Chitto Creek (site 7) in the Limited Use Area, Vernon Ranger

District, Kisatchie National Forest, Louisiana,

A. daily specific conductance data, November 1996 to February 1997 ................. 79

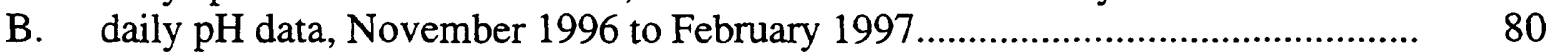

C. daily water temperature data, November 1996 to February 1997 .................... 81

8. West Fork of Sixmile Creek (site 11) in the Limited Use Area, Vernon

Ranger District, Kisatchie National Forest, Louisiana,

A. daily specific conductance data, November 1996 to February 1997 ................. 82

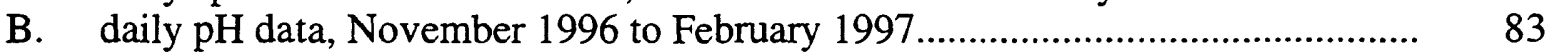

C. daily water temperature data, November 1996 to February 1997 .................... 84

9. East Fork of Sixmile Creek (site 13) in the Limited Use Area, Vernon

Ranger District, Kisatchie National Forest, Louisiana,

A. daily specific conductance data, November 1996 to February 1997 ................. 85

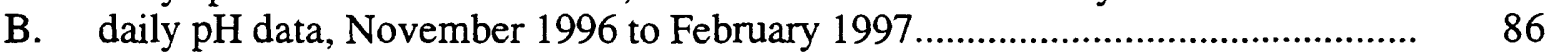

C. daily water temperature data, November 1996 to February 1997 ....................... 87

10. Sixmile Creek (site 15) south of the Limited Use Area, Vernon Ranger

District, Kisatchie National Forest, Louisiana,

A. daily specific conductance data, November 1996 to February 1997 ...................

B. daily pH data, November 1996 to February 1997.

C. daily water temperature data, November 1996 to February 1997

11. Calcium concentrations, in milligrams per liter $(\mathrm{mg} / \mathrm{L})$, for daily sampling sites in the Limited Use Area, Vernon Ranger District, Kisatchie National

Forest, Louisiana

12. Magnesium concentrations, in milligrams per liter ( $\mathrm{mg} / \mathrm{L})$, for daily sampling sites in the Limited Use Area, Vernon Ranger District, Kisatchie National Forest, Louisiana

13. Major inorganic ion data for daily sampling sites in the Limited Use Area, Vernon Ranger District, Kisatchie National Forest, Louisiana

14. Percent silt, sand, and gravel of sediments collected from sampling sites in the Limited Use Area, Vernon Ranger District, Kisatchie National

Forest, Louisiana

15. Concentrations of trace metals and major cations in bottom material from sampling sites in the Limited Use Area, Vernon Ranger District, Kisatchie National Forest, Louisiana.

16. Analyses of explosive compounds in bed materials collected from sampling sites in the Limited Use Area, Vernon Ranger District, Kisatchie National Forest, Louisiana

17. Major ion and nutrient data for surface-water samples collected from sampling sites in the Limited Use Area, Vernon Ranger District, Kisatchie National Forest, Louisiana 
18. Percent difference of cation/anion balance values for water samples collected from sampling sites in the Limited Use Area, Vernon Ranger District,

Kisatchie National Forest, Louisiana.

19. Analyses of bacteria in surface-water samples collected from sampling sites in the Limited Use Area, Vernon Ranger District, Kisatchie National Forest, Louisiana

CONVERSION FACTORS, VERTICAL DATUM, AND ABBREVIATED WATER-QUALITY UNITS

\begin{tabular}{rll}
\hline Multiply & By & To obtain \\
\hline inch $(\mathrm{in})$. & 25.4 & millimeter \\
foot $(\mathrm{ft})$ & 0.3048 & meter \\
mile $(\mathrm{mi})$ & 1.609 & kilometer \\
foot per mile $(\mathrm{ft} / \mathrm{mi})$ & 0.1894 & meter per kilometer \\
inches per year $(\mathrm{in} / \mathrm{yr})$ & 2.54 & centimeter per year \\
square foot $\left(\mathrm{ft}^{2}\right)$ & 0.09290 & square meter \\
square mile $\left(\mathrm{mi}^{2}\right)$ & 2.590 & square kilometer \\
\hline
\end{tabular}

Sea level: In this report, "sea level" refers to the National Geodetic Vertical Datum of 1929--a geodetic datum derived from a general adjustment of the first-order level nets of both the United States and Canada, formerly called Sea Level Datum of 1929.

Temperature in degrees Fahrenheit $\left({ }^{\circ} \mathrm{F}\right)$ can be converted to degrees Celsius $\left({ }^{\circ} \mathrm{C}\right)$ as follows: ${ }^{\circ} \mathrm{C}=\left({ }^{\circ} \mathrm{F}-32\right) / 1.8$.
Abbreviated water-quality units:
milligrams per liter (mg/L)
microsiemens per centimeter at 25 degrees Celsius $(\mu \mathrm{S} / \mathrm{cm})$
micrograms per gram $(\mu \mathrm{g} / \mathrm{g})$
milliequivalents per liter (meq/L)
micrograms per kilogram $(\mu \mathrm{g} / \mathrm{kg})$
millimoles per liter $(\mathrm{mmol} / \mathrm{L})$
micrometer $(\mu \mathrm{m})$
micrograms per liter $(\mu \mathrm{g} / \mathrm{L})$ 


\title{
Water-Quality Data and Descriptions of Biota for Selected Watersheds of the Limited Use Area, Vernon Ranger District, Kisatchie National Forest, Louisiana, September 1996 through March 1997
}

\author{
By Roland W. Tollett and Robert B. Fendick, Jr.
}

\begin{abstract}
The U.S. Army Joint Readiness Training Center and Fort Polk is studying the potential impacts of conducting increased training exercises on approximately 45,000 acres of the Kisatchie National Forest. The area being considered for increased use is known locally as the Limited Use Area (LUA) of the Vernon Ranger District, Kisatchie National Forest, and is located south of the Fort Polk Military Reservation. The proposed land use would involve increased types and frequencies of training activities. The increased use could affect the water quality of streams in the watersheds of the LUA, including the downstream reaches of Whiskey Chitto Creek and Sixmile Creek. These reaches are a part of the Louisiana Natural and Scenic Rivers System.

Water-quality data are presented for 14 stream sites situated in the LUA and one additional site south of the LUA. Specific conductance, in microsiemens per centimeter at 25 degrees celsius $(\mu \mathrm{S} / \mathrm{cm})$, and $\mathrm{pH}$ values are lowest ( $7 \mu \mathrm{S} / \mathrm{cm}$ and 4.95 , respectively) in the eastern part of the LUA, and the values increase $(226 \mu \mathrm{S} / \mathrm{cm}$ and 7.35 , respectively) in the western part of the LUA. Daily calcium and magnesium data for the six sites are presented in tables. Calcium values ranged from less than $1 \mathrm{mg} / \mathrm{L}$ (milligram per liter) in Sixmile Creek to greater than $15 \mathrm{mg} / \mathrm{L}$ in Whiskey Chitto Creek . Magnesium values ranged from $1.3 \mathrm{mg} / \mathrm{L}$ in Whiskey Chitto Creek to less than $0.6 \mathrm{mg} / \mathrm{L}$ in Sixmile Creek. Some trace metal concentrations are above detection limits but below background levels for the area. Concentrations of explosive compounds in bed material are below detection limits at the 14 sites sampled. Periphyton algal community samples collected at the sites within the LUA are representative of communities found in mineral-poor waters, low in alkaline earths and in buffering capacity, as described in other localities in the United States. Freshwater mussel populations are lowest in the headwaters of the Sixmile Creek system. Descriptions of terrestrial biota, including plant species, vegetation type, and rare and endangered species, indicate that the LUA has a high level of diversity of both plants and animals.
\end{abstract}

\section{INTRODUCTION}

The U.S. Army Joint Readiness Training Center and Fort Polk is studying the potential effects of conducting increased training exercises on approximately 45,000 acres of the Kisatchie National Forest. The area being considered for increased use is known as the Limited Use Area (LUA) of the Vernon Ranger District, Kisatchie National Forest, and is located south of the Fort Polk Military Reservation (hereinafter referred to as the Reservation) (fig. 1). The proposed land use would involve increased types and frequencies of training activities. 

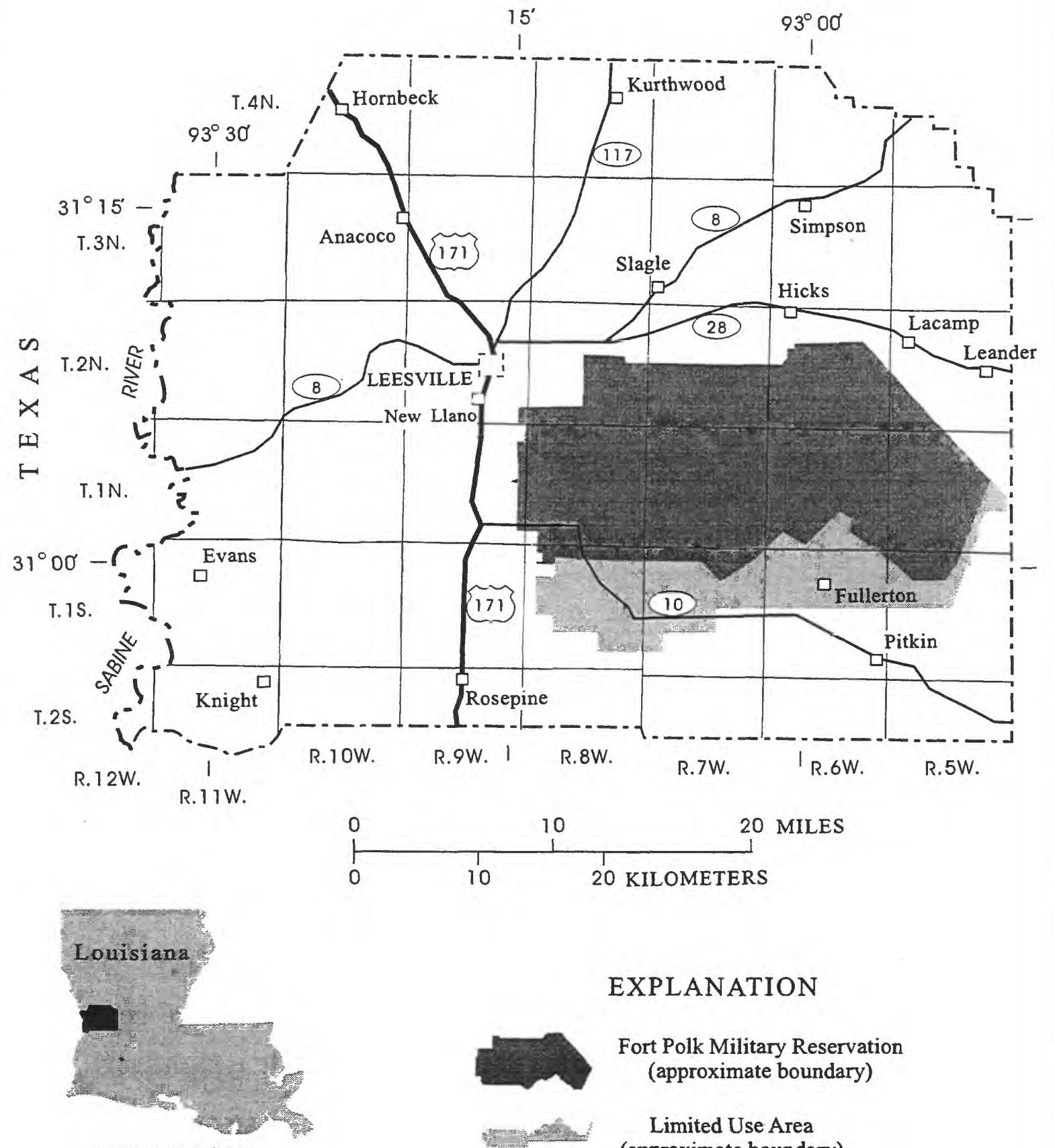

INDEX MAP

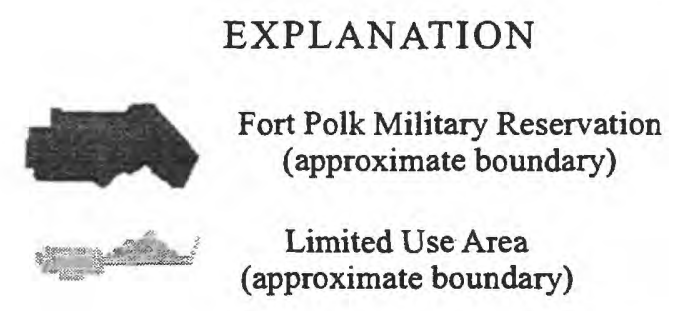

Figure 1. Fort Polk Military Reservation and the Limited Use Area of the Kisatchie National Forest, Vernon Ranger District, Vernon Parish, Louisiana. 
The expanded use could affect the water quality of streams in the watersheds. Background information and data are needed to describe the water quality (defined as the fitness of water for use, being affected by physical, chemical, and biological factors) of streams located in the LUA. In September 1996, the U.S. Geological Survey (USGS), in cooperation with the U.S. Forest Service (USFS) and the U.S. Army, began a study designed to collect and document the water-quality data and biota for perennial creeks and associated watersheds draining the LUA, with additional emphasis on the scenic rivers.

The southern reaches of two streams, Whiskey Chitto and Sixmile Creek, located within the LUA are included in the Louisiana Natural and Scenic Rivers System. These reaches are a part of approximately 1,400 miles of Louisiana streams that are protected through a State law enacted in 1970. A natural and scenic river is defined as a free-flowing river, stream, or bayou that has not been altered by mankind in the last 25 years, has no or few man-made structures on its banks, and has native vegetation covering its shoreline (Cormier and others, 1990, p. 58).

\section{Purpose and Scope}

This report presents water-quality data and descriptions of biota for selected watersheds in the LUA. Descriptive information and data on watersheds and streams are included. Field and laboratory methods used in the collection of water-quality data by the USGS are described, and all data collected are presented in tables.

Water-quality data are presented for five sites within the LUA and one south of the LUA along the scenic streams. Data presented for six sampling sites include daily minimum, median, and maximum values for specific conductance, $\mathrm{pH}$, and water temperature; daily sample composites of calcium and magnesium concentrations; and major inorganic chemical data.

Additional data are presented for 14 sites, five sites (mentioned above) along the scenic streams as well as nine other sites located within the LUA. These data, which provide areal stream coverage, include physical properties and chemical constituents in surface water and chemical constituents in bottom material; bacteria; sediment grain size in bottom material; periphyton species identification; freshwater mussel identification and population counts; and terrestrial biota such as plant species, vegetation type, rare and endangered species, and bog locations.

Knowledge of current (1997) water-quality conditions of the streams within the LUA will aid the U.S. Forestry Service and the U.S. Army in assessing potential effects of expanded military training exercises. The water-quality data presented in this report will be included in an Environmental Assessment of the LUA.

\section{Acknowledgments}

The authors express appreciation to Charles H. Stagg, Chief of the Environmental and Natural Resources Management Division of the Directorate of Public Works for the U.S. Army Joint Readiness Training Center and Fort Polk, for assistance provided during the design and preparation of this report. The authors also extend their appreciation to Malcom F. Vidrine, professor of biology at Louisiana State University at Eunice, Louisiana, for conducting field work and providing and summarizing freshwater mussel data; Charles M. Allen, professor of biology at Northeast Louisiana University, for conducting field work and providing descriptions of biota; and Fred Bryan for conducting periphyton analyses.

\section{DESCRIPTION OF THE STUDY AREA}

The study area is located in the southern half of Vernon Parish, Louisiana, extending from southeast of Leesville to northwest of Pitkin, Louisiana. The relative locations and approximate boundaries of the Reservation and the LUA in Vernon Parish are shown in figures 1 and 2. Information on the environmental setting and climate is included to provide an overview of the LUA and surrounding areas. 


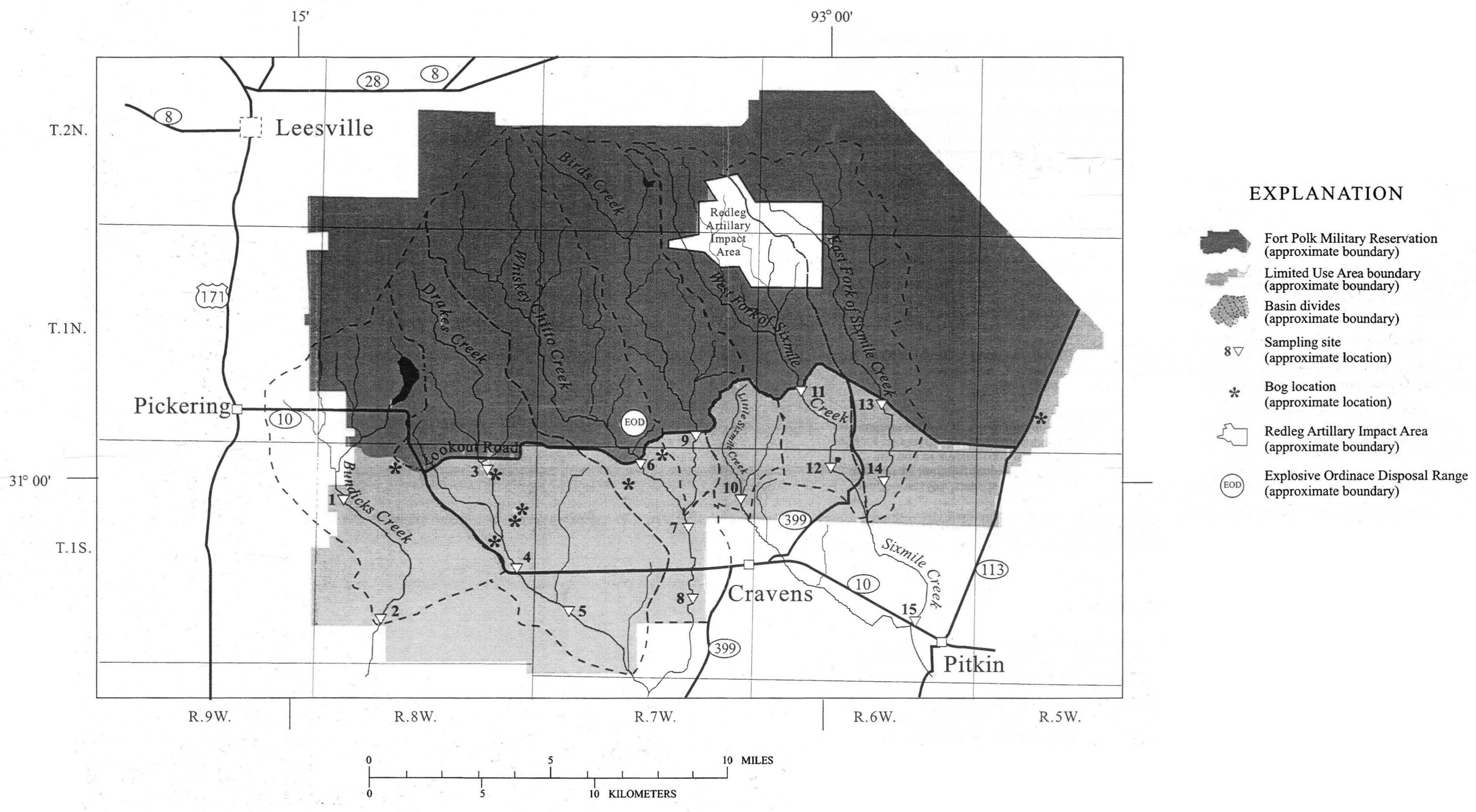

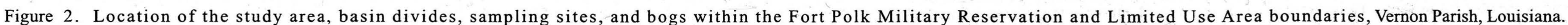




\section{Environmental Setting}

The study area is located on a topographic high and is near the headwaters of the Calcasieu River system. The headwaters of Whiskey Chitto Creek and West and East Fork of Sixmile Creek, and the two scenic rivers originating on the Reservation, flow through the LUA (fig. 2) are of particular concern to the U.S. Army. Whiskey Chitto Creek drains the land containing the Explosive Ordnance Disposal (EOD) Range, while West and East Fork of Sixmile Creek drain the Redleg 1 Artillery Impact Area (fig. 2). Downstream, south of the Reservation, the reaches of Whiskey Chitto Creek and Sixmile Creek are a part of the Louisiana Natural and Scenic Rivers System. Other streams of concern in the study area are Birds (a tributary to Whiskey Chitto Creek) Bundick, Drakes, and Little Sixmile Creeks.

The streams in the study area are first, second, and third order streams that drain hilly, dense piney uplands lacking intensive agricultural and/or urban use. The altitude of the drainage divides north of the study area range from 400 to 450 feet above sea level, with the outlets of the drainage basins at the southern boundary of the LUA ranging from 150 to 200 feet above sea level. The drainage basins are characterized by loamy soils, high runoff and infiltration, and rapid changes in creek stages during heavy rainfall. The primary land uses within the study area are recreation, logging, and limited military training activities.

Unconsolidated sedimentary deposits, ranging in age from Miocene to Pleistocene, crop out in Vernon Parish and the LUA. Only sediments of the Castor Creek and Blounts Creek Members (Evangeline aquifer) of the Fleming Formation and Pleistocene deposits are present at the surface in the LUA (fig. 3). Stratigraphic units and hydrogeologic units are shown in figure 4.

\section{Climate}

The climate is humid subtropical. The average annual rainfall for the 5-year period 1992-96 was 58.3 inches at the Fort Polk Airfield. During 1992-96, annual rainfall ranged from 48.03 inches in 1992 to 74.52 inches in 1995. The drier months are during late summer (August) through early fall (October) (Lieutenant Patricia Vollmer, Fort Polk Airfield Weather Station, written commun., 1997). In 1996, the average temperature for the study area was $65.3^{\circ} \mathrm{F}$, a -0.1 departure from normal; the high temperature was $98^{\circ} \mathrm{F}$ on July 13; and the low temperature was $12^{\circ} \mathrm{F}$ on February 4 . The coldest months are December through February, with a average temperature of $48.7^{\circ} \mathrm{F}$. The hottest months are June through August, with a average temperature of $78.5^{\circ} \mathrm{F}$ (National Oceanic and Atmospheric Administration, 1996).

\section{DATA COLLECTION AND PRESENTATION}

Methods used to collect descriptive information and data on watersheds and streams, water-quality, and biota are discussed in this section. Brief discussions of the data that were collected and analyzed are included. The data and corresponding figures are presented at the back of the report.

Data were collected at 15 sites (fig. 2 and table 1): 2 on Bundick Creek, 3 on Drakes Creek, 3 on Whiskey Chitto Creek, 1 on Birds Creek, 1 on Little Sixmile Creek, and 2 each on West and East Fork of Sixmile Creek within the LUA; 1 was on Sixmile Creek south of the LUA. Most of the data for the study was collected in the fall of 1996 . No historical water-quality data in the LUA were available for the two scenic rivers.

Drainage areas for watersheds encompassing the LUA were calculated using the horizontal plane enclosed by the topographic divide where direct surface runoff drains into the stream from a specific point along the stream (Sloss, 1971). Drainage areas were measured using an Altek AC40 digitizer and the Fort Polk Military Installation Map, 1976 edition. Basin gradients were calculated using the "85-10" slope factor as described by Singh (1992).

Stream habitats were characterized at the basin, segment, and reach levels, using protocols outlined by the USGS (Meador and others, 1993). Stream habitat characterization includes physical, chemical, and biological data that represent major natural and human factors, such as ecoregion, stream size, riparian habitat, hydrology, and geology. Field surveys were conducted at the 14 sampling sites in the LUA, and 


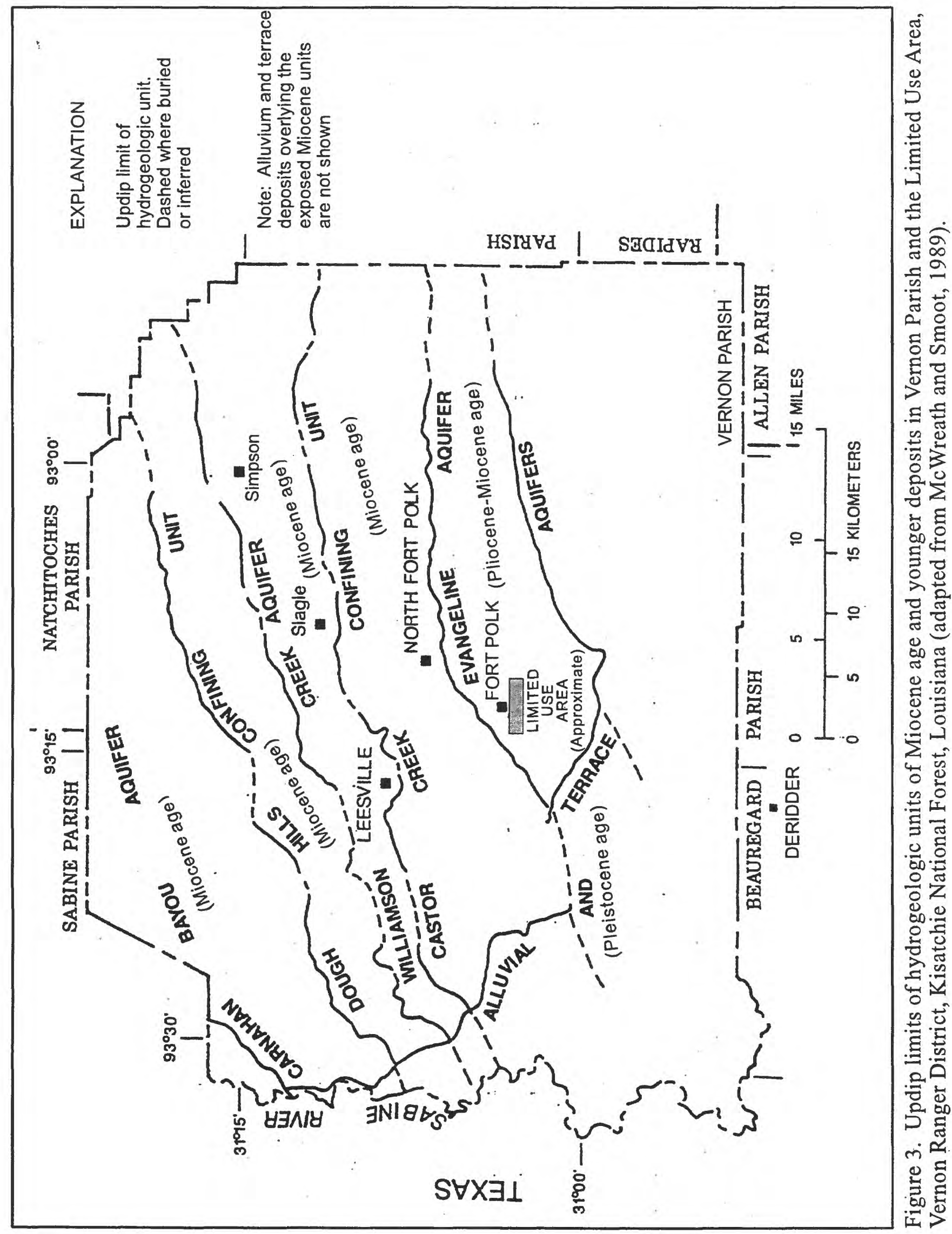




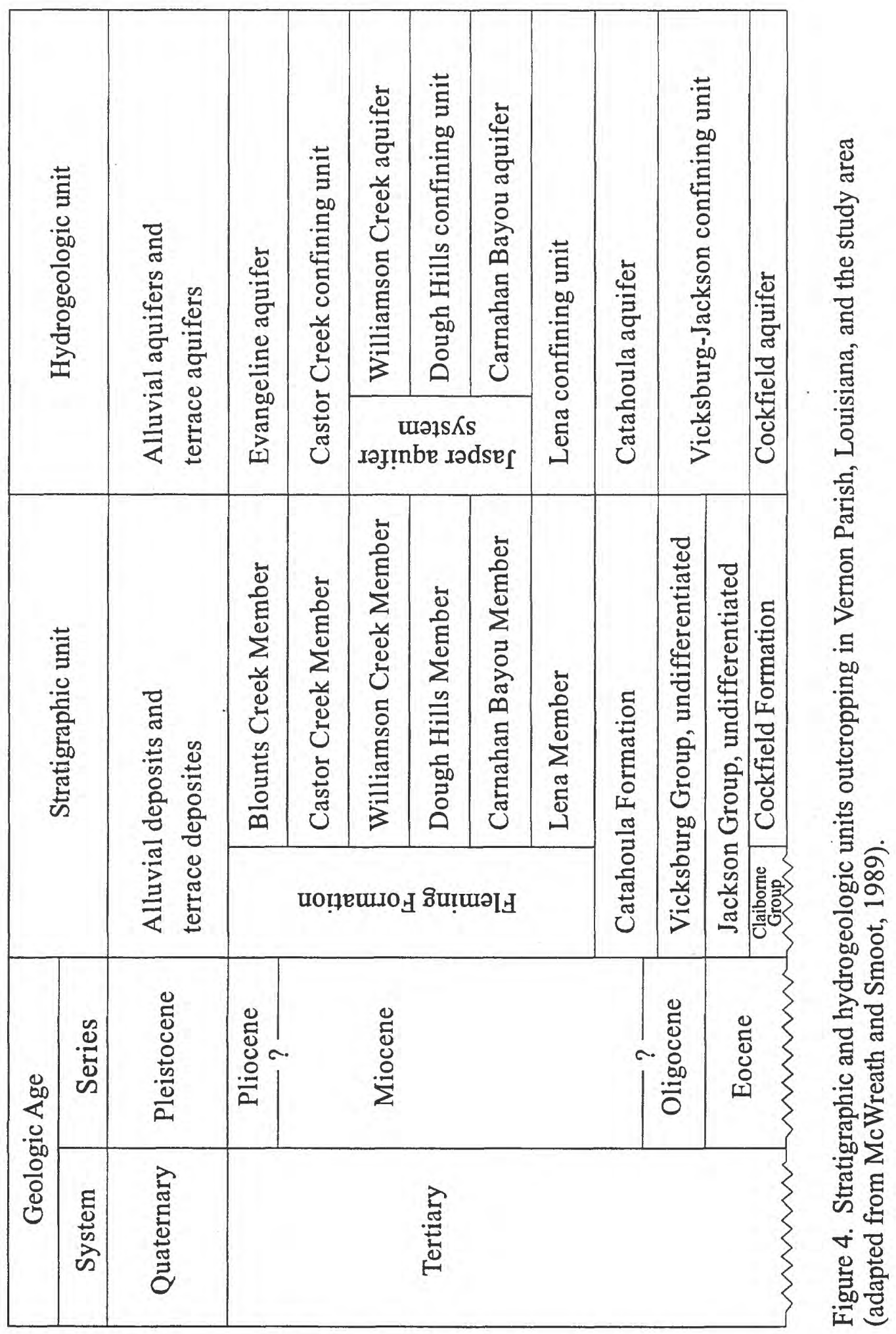




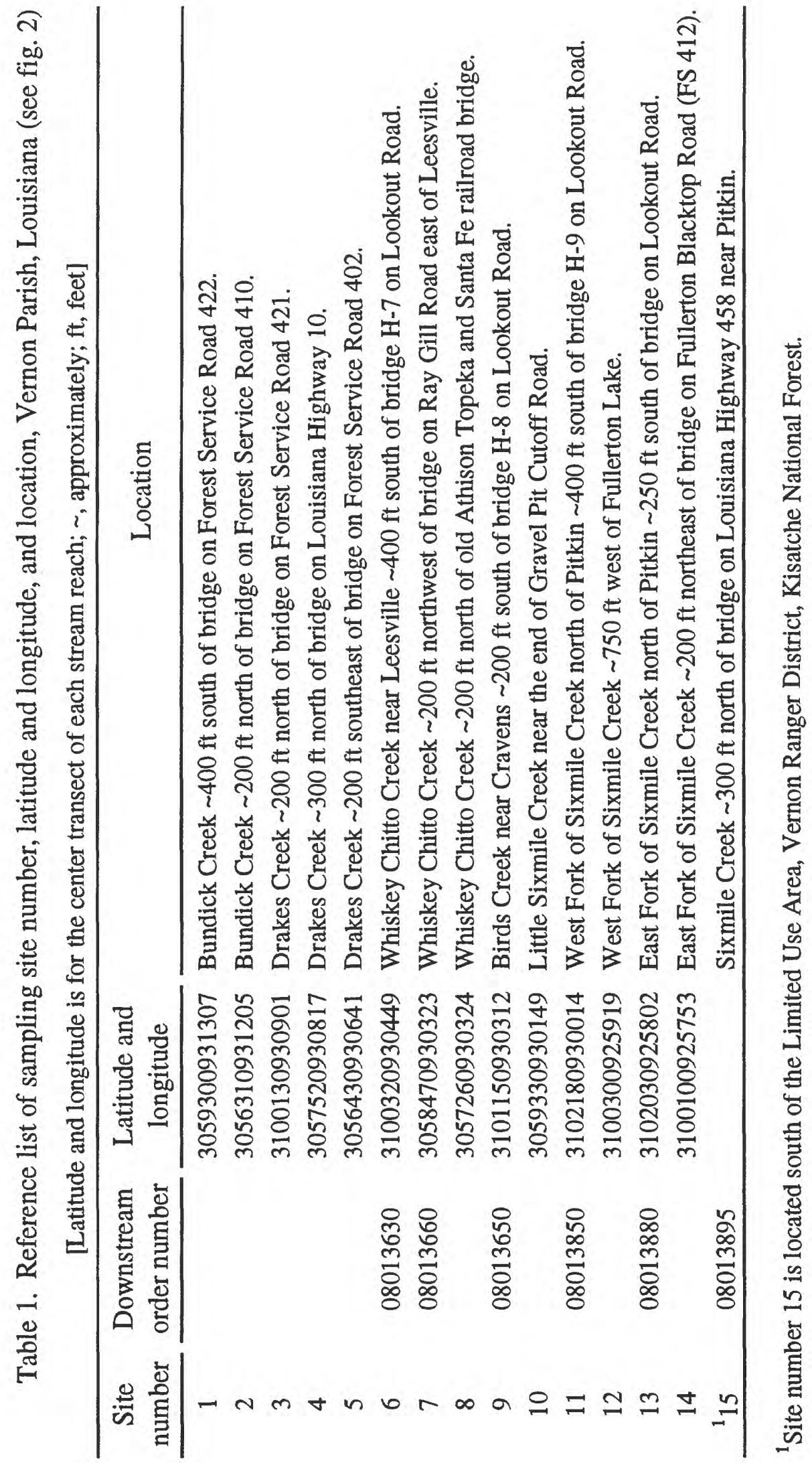


data were entered into the reach characterization section of the stream habitat assessment. A wading rod, a Price AA flow meter, and a digitizer were used to collect velocity measurements. A Brunton compass and Suunto clinometer were used to measure downstream flow direction, canopy angles, and bank angles. A secchi disk was used to measure light penetration.

Stream habitat characterization forms are presented in figures 12-25. The stream characterization form is divided into three sections: basin, stream segment, and a first-level reach. A site map corresponding to each of the 14 stream reach characterization forms is included in the first-level reach section (figures 12-25, at back).

Information on basin area, length, and gradient is listed in table 2 (at back). Additional area calculations were performed to document the extent of public land within the LUA, net acreage of the Kisatchie National Forest Land within the LUA, and drainage area for each sampling site outlet. The Whiskey Chitto system, which includes Birds Creek, has the largest drainage area, followed closely by the Sixmile Creek drainage area, which consists of East Fork and West Fork Creek. Stream length, change in elevation, and basin gradient for each sampling site also are presented. Little Sixmile Creek has the steepest basin gradient, approximately 31 feet per mile and Whiskey Chitto Creek had the lowest basin gradient, approximately 12 feet per mile.

Brief descriptions of the surface soils in the LUA are listed in table 3 (at back) (Herbert McDaniel, U.S. Department of Agriculture-Natural Resources Conservation Service, written commun., 1997). The surface soils of the upland areas of the LUA tend to be well drained with low natural fertility, and the surface soils in lower areas tend to be acidic and poorly drained. Table 4 (at back) lists the location of these soils in the LUA based on slope and position within the watershed.

\section{WATER QUALITY}

Water-quality sampling for the two scenic rivers included collecting physical and chemical data. Physical properties data included average daily specific conductance, $\mathrm{pH}$, and temperature; chemical data included major inorganic ions and daily calcium and magnesium concentrations.

\section{Reaches of Louisiana Scenic Rivers}

Daily water-quality data were collected from November 1996 to February 1997 for six sites on the two Louisiana Natural and Scenic Rivers in the LUA. Results for physical properties and chemical data for the two scenic rivers are presented in the following discussions.

Physical properties were determined hourly with on-site multiparameter water-quality data recorders from November 5,1996, to February 18,1997, at sites 6 and 7 along Whiskey Chitto Creek, site 9 along Birds Creek, site 11 along West Fork Creek, site 13 along East Fork Creek, and site 15 along Sixmile Creek (fig. 2). These water-quality data recorders were placed on the stream bottom for collection of data to determine physical properties, including specific conductance, $\mathrm{pH}$, and temperature.

Daily minimum, maximum, and median values for specific conductance, $\mathrm{pH}$, and temperature are presented in tables $5 \mathrm{~A}$ to $10 \mathrm{C}$ (at back) for sites $6,7,9,11,13$, and 15 . Plots representing the daily median values are presented in figures 5 to 7 . Some data values were missed when the water-quality recorders were removed from the field for monthly cleaning and calibration checks. Additional data were omitted due to probe fouling and burial by sediments and debris. Specific conductance and $\mathrm{pH}$ values are lowest ( $7 \mu \mathrm{S} / \mathrm{cm}$ and 4.95 , respectively) in the eastern part of the LUA (Sixmile Creek), and increase ( $226 \mu \mathrm{S} / \mathrm{cm}$ and 7.35 , respectively) towards the western part the LUA.

To determine chemical constituents, water samples were collected from sites $6,7,9,11,13$, and 15 using an automatic ISCO water sampler and by dipping. ISCO samplers were set to collect 1 liter of water daily from sites 11,13 , and 15 . For consistency, dipping samples were collected daily, with the exception of weekends, from sites 6, 7, and 9. Daily samples were filtered through a 142 millimeter (mm) diameter 0.45 micron cellulose nitrate membrane filter. The samples were then treated with nitric acid and shipped 


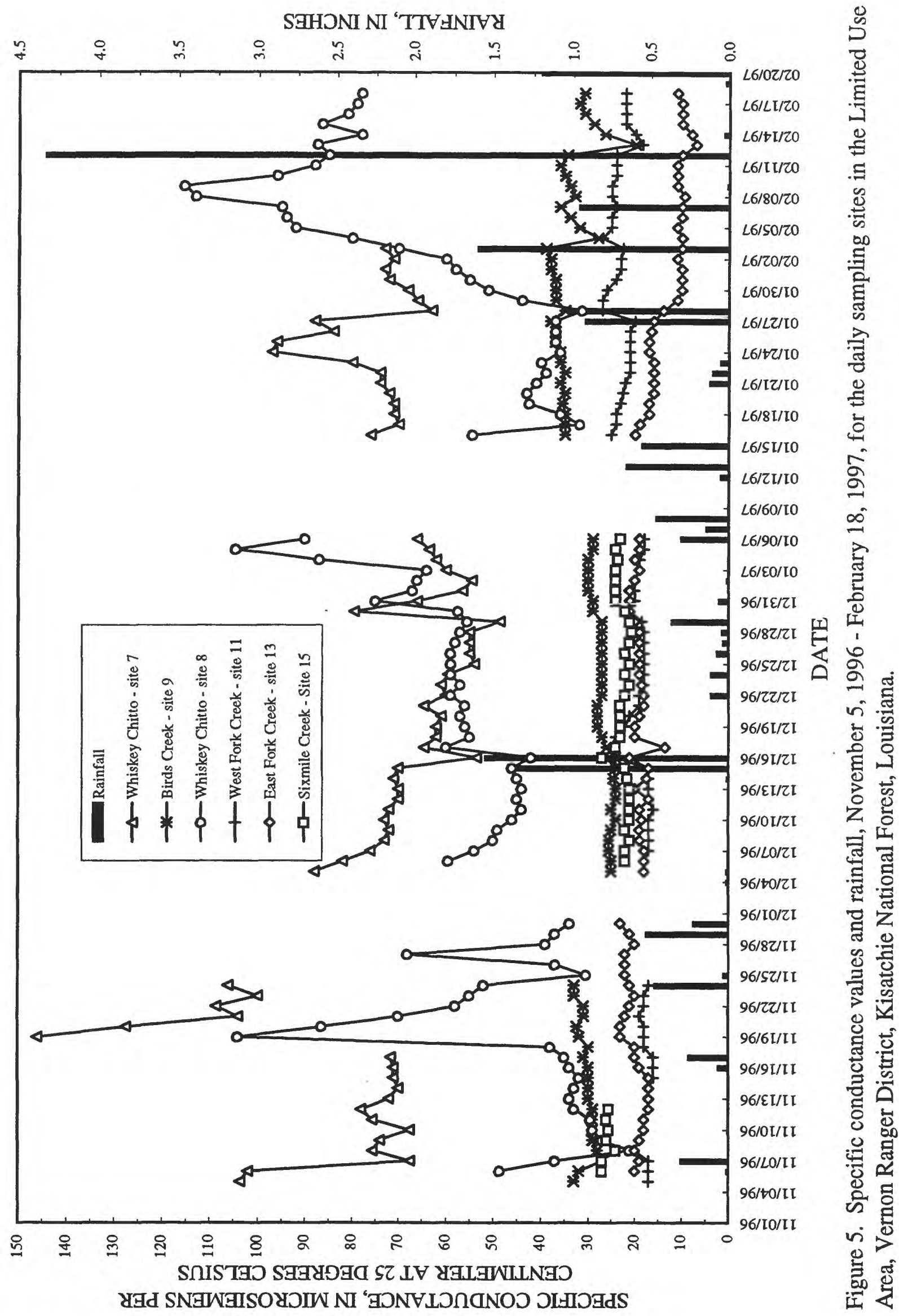




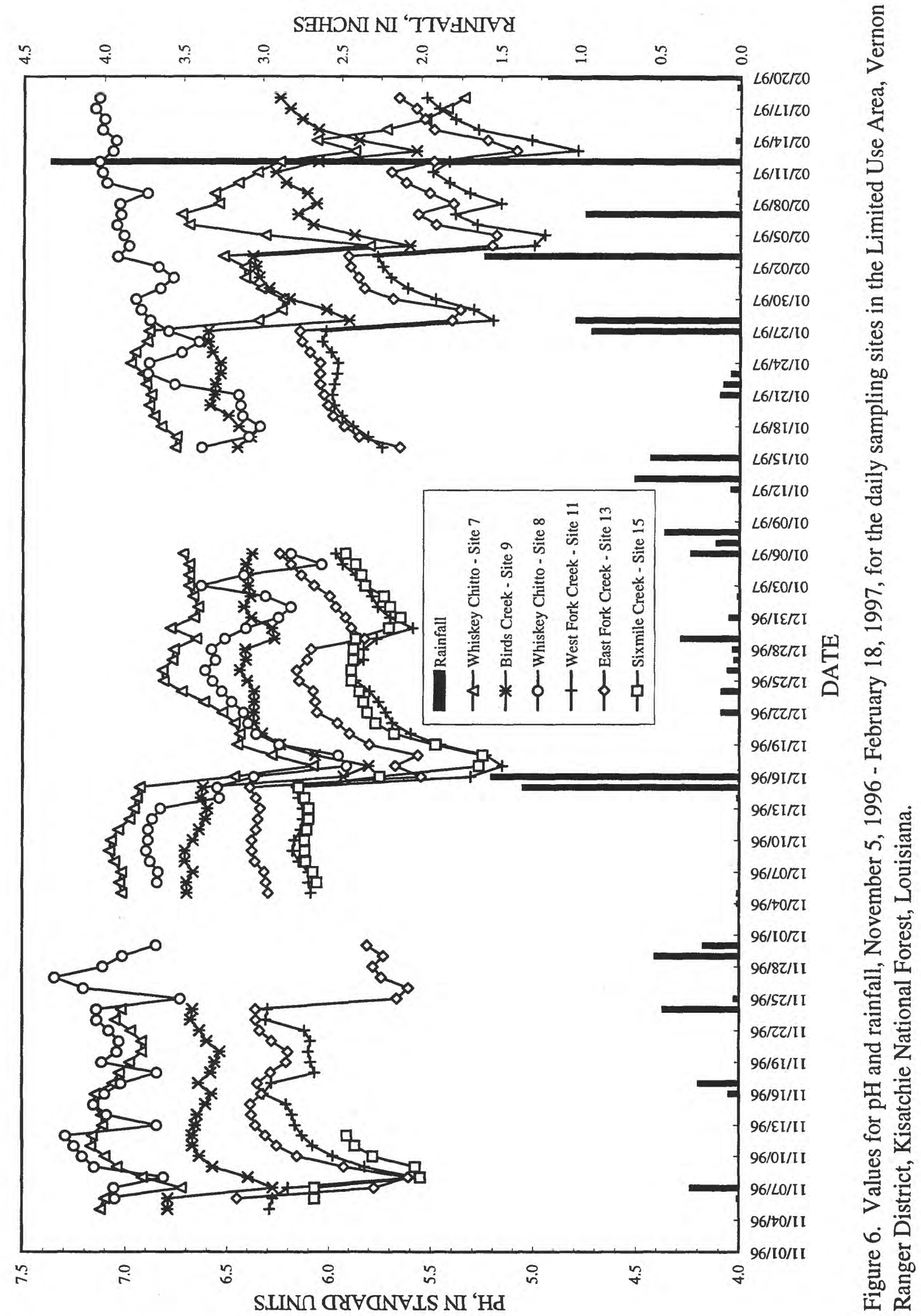




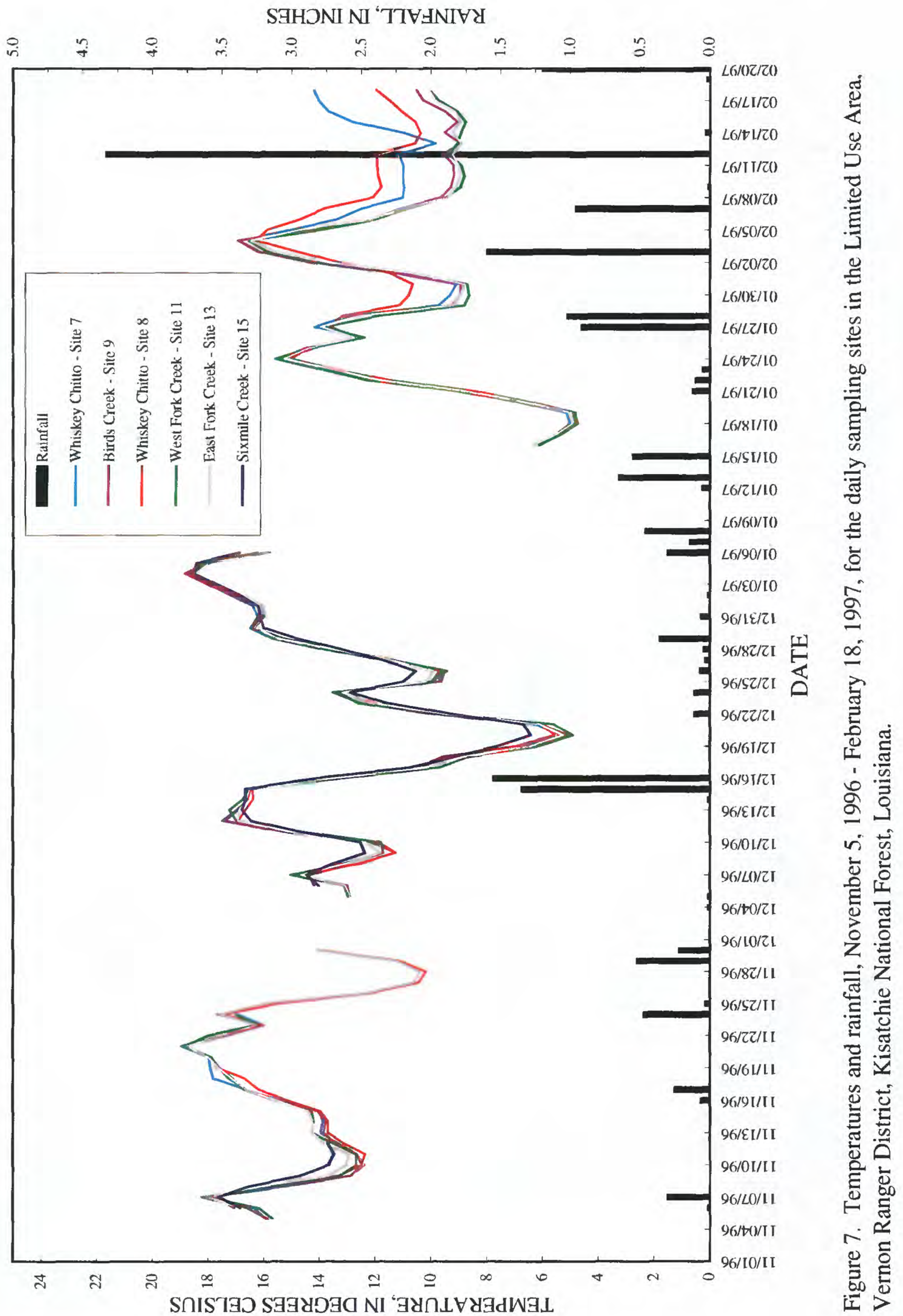


to a USGS laboratory for analysis. Samples were analyzed for calcium and magnesium, with additional cations and anions measured every 10th sample. Approximately $10 \%$ of the samples analyzed were field duplicates or deionized water blanks (Horowitz and others, 1994).

Daily calcium and magnesium data for the six sites are presented in tables 11 and 12 (at back). Calcium values ranged from less than $1 \mathrm{mg} / \mathrm{L}$ in Sixmile Creek to greater than $15 \mathrm{mg} / \mathrm{L}$ in Whiskey Chitto Creek. Magnesium values ranged from $1.3 \mathrm{mg} / \mathrm{L}$ in Whiskey Chitto Creek to less than $0.6 \mathrm{mg} / \mathrm{L}$ in Sixmile Creek. Graphical representations of calcium and magnesium data are presented in figures 8 and 9 , respectively. Major inorganic ion data for the six sites are presented in table 13 (at back). Again, the Whiskey Chitto system showed higher ion concentrations than Sixmile Creek. Piper diagrams, based on chemical ion percentages, are presented to indicate water type (figs. 10 and 11) (Hem, 1985). Alkalinity was used to calculate bicarbonate concentrations. Values for $\mathrm{pH}$ ranged from 4.95 to 7.35 ; therefore, only the bicarbonate species was considered as a contributor to alkalinity (Hem, 1985).

\section{Areal Stream Coverage}

Water-quality data were collected at 14 sampling sites in the LUA from December 5 through 11, 1996 (fig. 2). Water-quality sampling at the sites included collecting bed material, physical properties, chemical constituents, and biological data. Bed material analyses included sediment grain-sizes, explosive compounds, and trace metal concentrations. Chemical constituents included nutrients and major inorganic ion analyses. Biological data included bacteria and periphyton analyses. Data for the sites are presented in the following discussions.

Bed-material samples were collected using a stainless-steel petite ponar. Standing downstream of the ponar, the sampler was lowered onto the creek bed and the collected material was placed in a clean plastic pan. This procedure was repeated until enough material was collected for sediment grain-sizes, explosives, and trace metals analyses. The material was mixed thoroughly with a plastic spoon and scooped into appropriate containers. Chemical constituents analyses were performed by a USGS laboratory using methods described by Matthes (1992). Explosives were analyzed using U.S. Environmental Protection Agency (USEPA) method 8338.

Bed material samples were collected from the center transect of sites 1 through 14 . Results of the grain-size sediment analyses are presented in table 14 (at back). Grain-size sediment analyses indicate the bed material in the creeks sampled in the LUA is predominantly sand and gravel. Trace metal analyses and explosives analyses for bed-material samples collected at sites 1 through 14 are presented in tables 15 and 16 (at back). Concentrations of all explosives analyzed were below detection limits. Some trace metal concentrations were above detection limits but below background levels for the region.

Chemical constituents were determined from water samples collected from creeks by dipping samples, because the creeks were shallow at most of the sampling sites. Samples were collected by standing downstream and dipping the appropriate bottle just below the surface of the water. The mouth of the bottle was pointed upstream, as near the center of flow as possible without disturbing the bottom sediments. The samples were analyzed for major inorganic ions and nutrients by the USGS using methods described by Fishman and Friedman (1989).

Water samples were collected from the center transect of sites 1 through 14 . Water-quality analyses are presented in table 17 (at back). Cation and anion balances and percent differences for the 14 sampling sites are listed in table 18 (at back). Cation and anion balances are used as a laboratory quality-control check.

Water samples were collected from the center transect of sites 1 through 14 for bacteria analyses. Water samples for analysis of fecal coliform and fecal streptococcus bacteria were collected by dipping, using a sterilized glass bottle. Bacteria samples were analyzed in the field using the multiple plate method (Britton and Greeson, 1989). Bacteria analyses by the USGS are presented in table 19 (at back). 


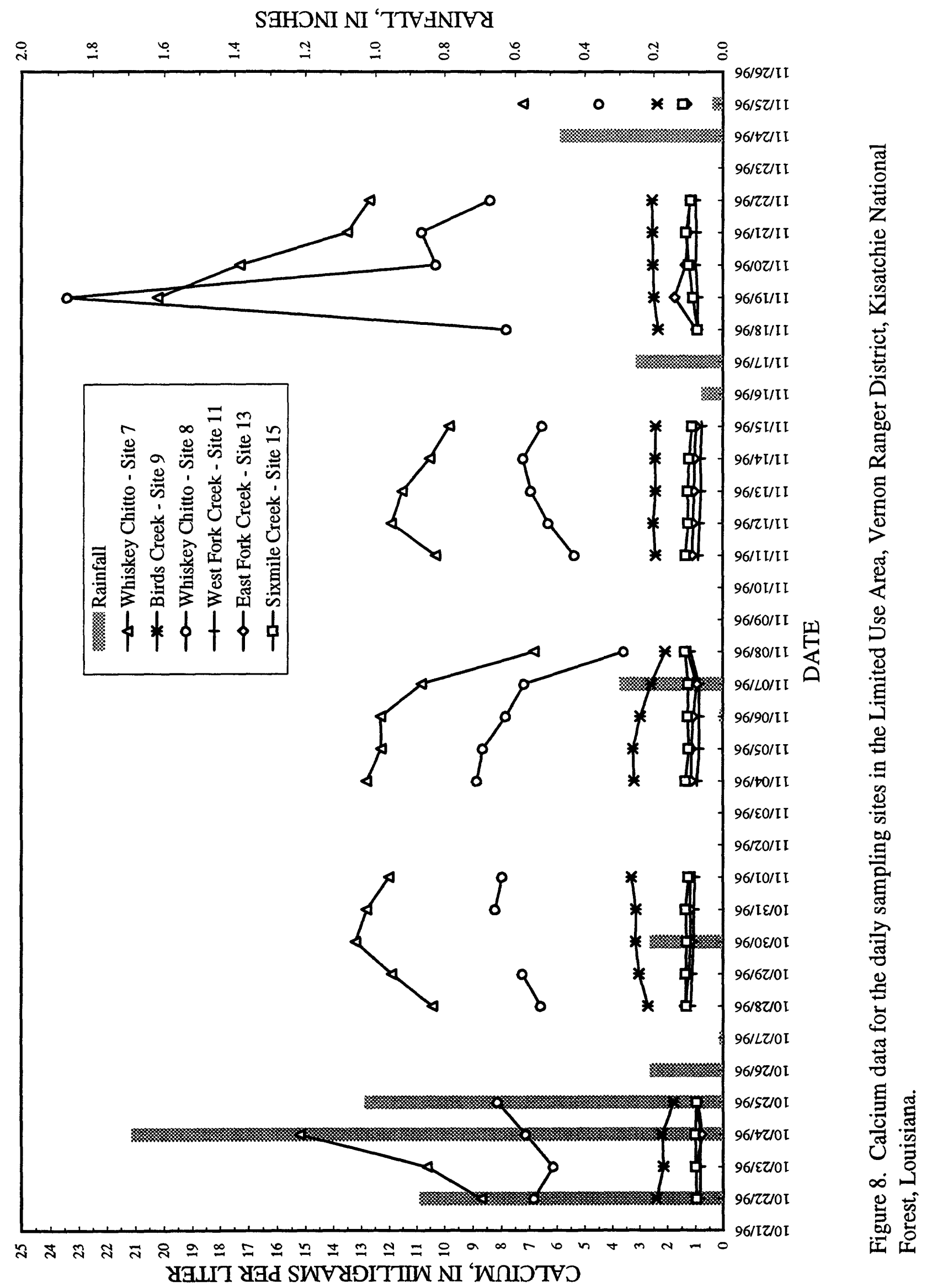


SAHDNI NI 'TTVANIVY

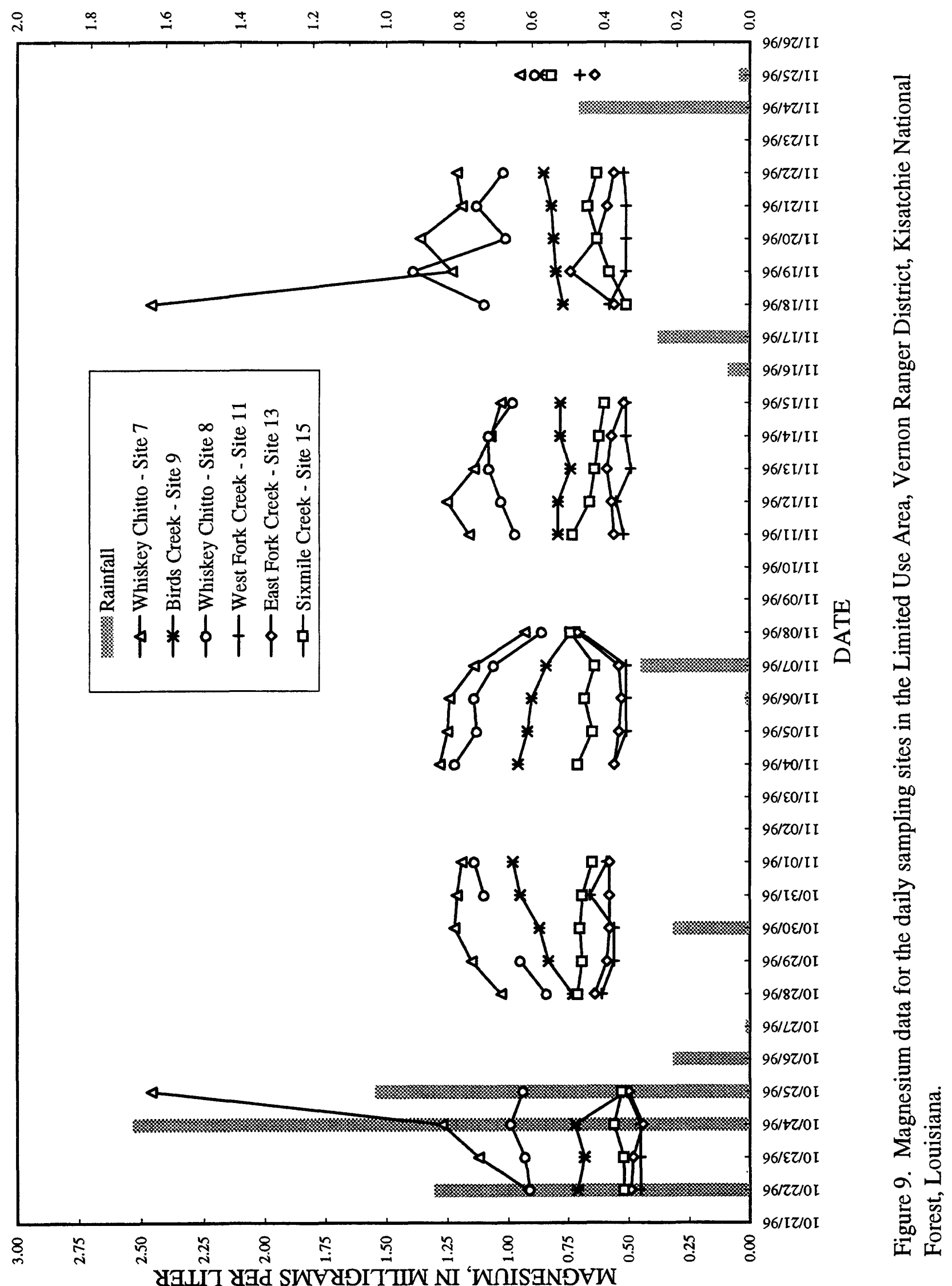




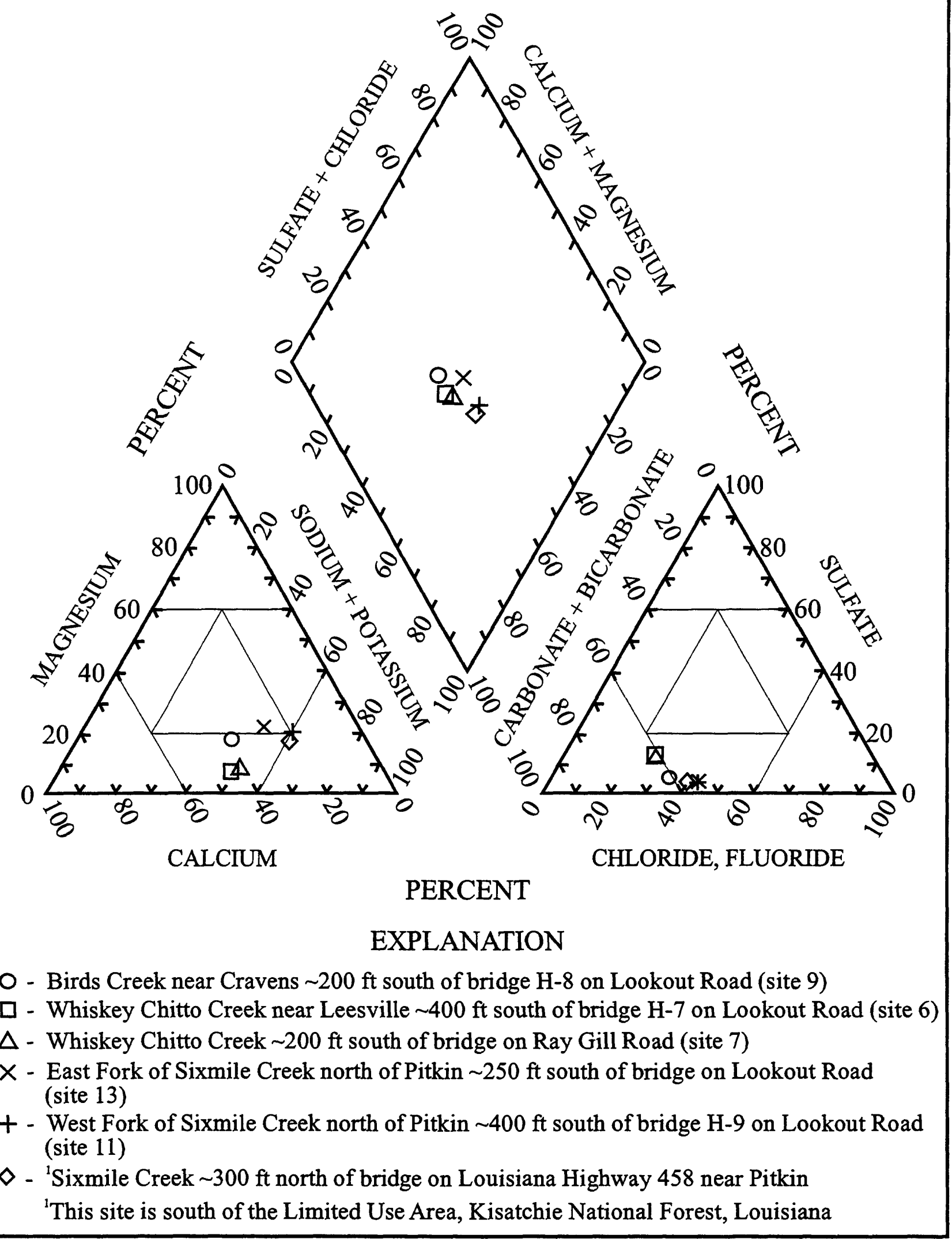

Figure 10. Piper diagram plotting major ion data for the daily sampling sites in the Limited Use Area, Vernon Ranger District, Kisatchie National Forest, Louisiana, October 22, 1996. 


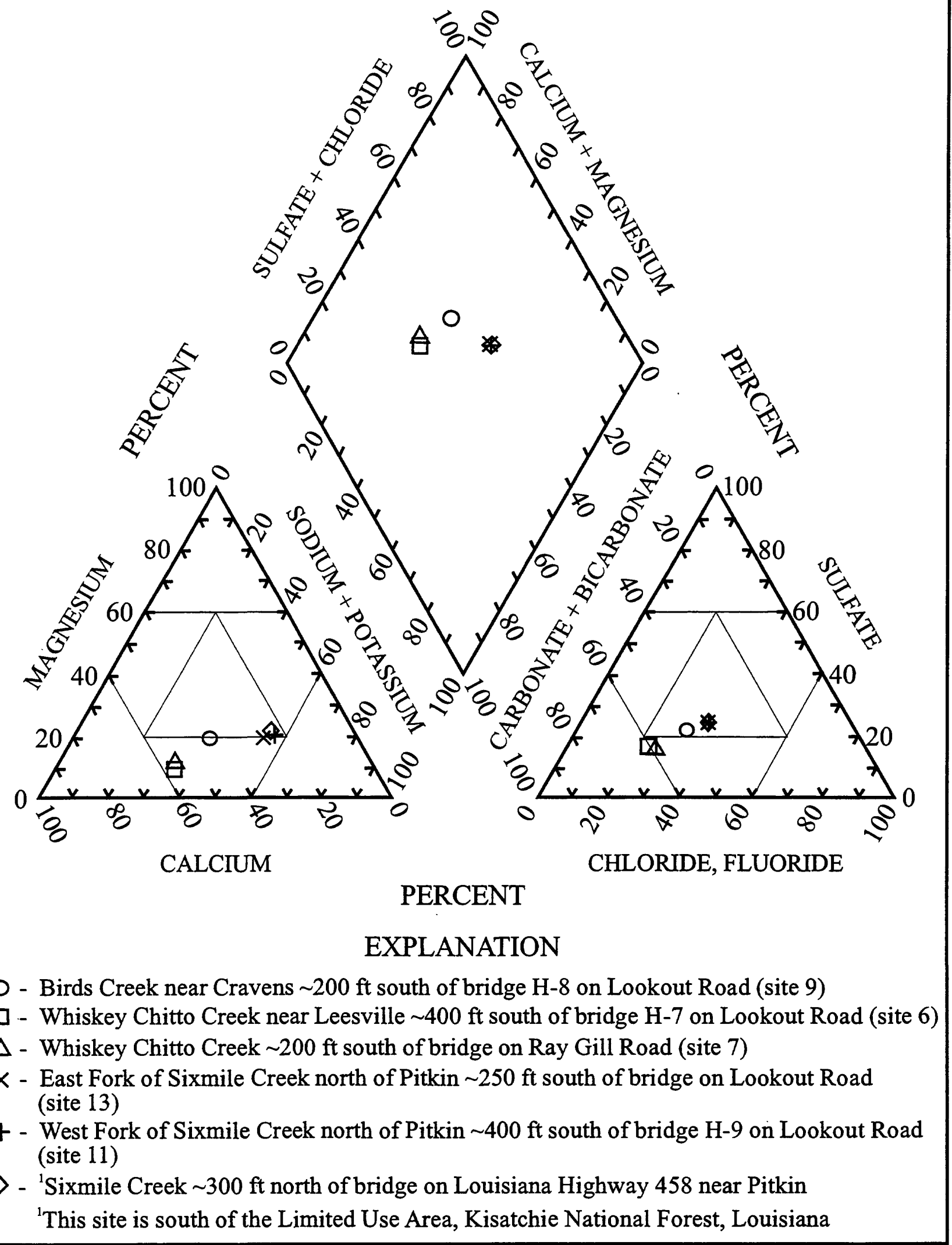

Figure 11. Piper diagram plotting major ion data for the daily sampling sites in the Limited Use Area, Vernon Ranger District, Kisatchie National Forest, Louisiana, November 5, 1996. 


\section{DESCRIPTION OF BIOTA}

Description of biota includes information and data on stream and terrestrial biota within the LUA. Stream biota include periphyton and freshwater mussel data; terrestrial biota include identifications of plant species, vegetation type, and rare and endangered species.

\section{Stream}

Stream biota include periphyton and freshwater mussel data collected at each stream reach. Periphyton communities and mussel populations are sensitive to a variety of environmental factors, such as temperature, oxygen, $\mathrm{pH}$, hardness, acidity, spates (flash floods), and food availability, and thus are good indicators of water quality (Hynes, 1970).

Periphyton samples were collected using a stainless steel knife blade to scrape a $2.5 \mathrm{~cm}$ (centimeter) by $5.0 \mathrm{~cm}$ area from submerged woody debris. This material was placed in a $250 \mathrm{~mL}$ (milliliter) plastic bottle, filled with stream water, treated with $12.5 \mathrm{ml}$ of formaldehyde, and shipped to a USGS laboratory for further analyses using the Utermohl (1958) method for the inverted microscope. The periphyton sample was diluted to $1 \mathrm{~L}$ (liter) and thoroughly mixed. Next, a 10-ml aliquot was transferred to a plankton sedimentation chamber (known area) and allowed to settle for approximately 24 hours. The periphyton sample was then placed on an inverted microscope (a Wild M40, equipped with a Plan-APO oil immersion objective -- 1000X). The dispersed algal cells seen upon examining one transect (one Whipple disc wide) were enumerated across the entire chamber; or simply, all algal cells were counted in approximately 290 fields. For colonies or filaments with large numbers of cells, the cells were counted in the entire colony. If cell counts within colonies were too large, cells were counted in a known area of the Whipple grid, then multiplied by the number of grids occupied by the colony.

Algal cell identifications for periphyton analyses of samples collected from 14 sampling sites in the LUA are listed in Appendix A, table A1 (F. Bryan, written commun., 1997). Raw counts of algal cells reflect the relative abundance of each taxon in the periphyton communities at each stream site. Cell counts can be expanded to numbers per $\mathrm{cm}^{2}$ of surface area of the substrate that was scraped at each site. Periphyton counts for replicate samples collected from sampling sites in the LUA are listed in Appendix A, table 2. Replicate sample counts do not match original counts: however, replicate sample counts provide a good measure to confirm major taxa in biological communities (F. Bryan, written commun., 1997). Periphyton algal community samples collected at the sites within the LUA are representative of communities found in mineral-poor waters, low in alkaline earths and in buffering capacity, as described in other localities in the United States.

Identification and population counts of freshwater mussels were performed by Louisiana State University at Eunice, Louisiana (M.F. Vidrine, written commun., 1997). The sampling consisted of nondestructive, visual identification and examination of each mussel from the stream bottom for a distance of 50 feet upstream and 50 feet downstream of the center transect of each site. In addition, notes were compiled based on habitat preferences of the individual freshwater mussel species.

Freshwater mussel data are presented in Appendix B (M.F. Vidrine, written commun., 1997). Freshwater mussel sampling sites correspond to the center transect of the 14 sampling sites. A list of freshwater mussels located at each sampling site is presented in Appendix B, table B2. A list of mussels, exotic clams, and snails of Louisiana is presented in Appendix B, table B1. A list of freshwater mussels from headwater creeks originating from Fort Polk, Peason Ridge, and the Kisatchie National Forest is presented in Appendix B, table B3. An additional list of other species that occur in headwater creek and larger creeks of the Kisatchie National Forest is presented in Appendix B, table B4. A list of the distribution of mussels in Louisiana streams in regards to provinces as they commonly occur in headwater streams is presented in Appendix B, table B5. Series of tables were extracted from Vidrine (1996c) referring to mussels collected from Fort Polk, Kisatchie National Forest, and the Calcasieu drainage downstream from the LUA and are presented in Appendix B, table B6. Freshwater mussel populations are lowest in the headwaters of the Sixmile Creek system. 


\section{Terrestrial}

Descriptions of terrestrial biota such as plant species, vegetation type, and rare and endangered species are presented in Appendix C (C.M. Allen, written commun., 1997). Vegetation descriptions of riparian zones and adjoining upland pine forests are described to species level. Vegetation types were categorized as bog, baygall, savannah, sandy, riparian, mixed and longleaf, disturbed areas, swamp, and water habitats. Bog locations selected for vegetation descriptions are shown in figure 2. Plant species and common names are presented in Appendix C, table $\mathrm{C}$. Plant species by vegetation types are presented in Appendix C, table C2. A list of rare and endangered species with State and Global Ranking from the Kisatchie National Forest Limited Use and Vicinity at either Fort Polk or Vernon Parish is presented in Appendix C, table C3. A list of plant species reported from only riparian habitats along the scenic streams in the LUA is presented in Appendix C, table C4. Descriptions of terrestrial biota indicate that the LUA has a high level of diversity of plants and animals (C.M. Allen, written commun., 1997).

\section{SELECTED REFERENCES}

Abington, O.D., Bullamore, H.W., and Johnson, D.C., 1993, Louisiana: A Geography (2d ed.): Lafayette, Louisiana, University of Southwestern Louisiana, Department of Geography/Urban and Regional Planning, $183 \mathrm{p}$.

Britton, L.J., and Greeson P.E., eds., 1989, Methods for collection and analysis of aquatic biological and microbiological samples: U.S. Geological Survey Techniques of Water Resources Investigations, book 5, chapter A4, 363 p.

Cormier, E.S., Andrus, Matthew, and Peterson, Briant, 1990, Water quality inventory in State of Louisiana Water Quality Management Plan, v. 5: Baton Rouge, Louisiana, Louisiana Department of Environmental Quality, Office of Water Resources, Water Quality Management Division, [100] p.

Defense Mapping Agency, 1976, Fort Polk Military Installation Map, edition 1-DMA, series V7855, sheet Special: Washington, D. C., Hydrographic/Topographic Center, scale 1:50,000.

Douglas, N.H., 1974, Freshwater Fishes of Louisiana: Louisiana Wild Life and Fisheries Commission and Claitor's Publishing Division, 443 p.

Fishman, M.J., and Friedman, L.C., eds., 1989, Methods for determination of inorganic substances in water and fluvial sediments: U.S. Geological Survey Techniques of Water-Resources Investigations, book 5, chap. A1, $545 \mathrm{p}$.

Fisk, H.N., 1940, Geology of Avoyelles and Rapides Parishes, Louisiana: Louisiana Department of Conservation Geological Bulletin 18, 240 p.

Guy, H.P., 1969, Laboratory theory and methods for sediment analysis: U.S. Geological Survey Techniques of Water-Resources Investigations, book 5, chap. C1, $58 \mathrm{p}$.

Harrelson, C.C., Rawlins, C.L., and Potyondy, J.P., 1994, Stream channel reference sites: an illustrated guide to field technique: General Technical Report RM-245, Fort Collins, Co., U.S. Department of Agriculture, Forest Service, Rocky Mountain Forest and Range Experiment Station, 61 p.

Hem, J.D., 1985, Study and interpretation of the chemical characteristics of natural water: U.S. Geological Survey Water-Supply Paper 2254, 225 p.

Horowitz, A.J., Demas, C.R., Fitzgerald, K.K., Miller, T.L., and Rickert, D.A., 1994, U.S. Geological Survey protocol for the collection and processing of surface-water samples for the subsequent determination of inorganic constituents in filtered water: U.S. Geological Survey Open-File Report 94-539, $57 \mathrm{p}$.

Hynes, H.B.N., 1970, The ecology of running waters: University of Toronto Press, 555 p.

Klug, M.L., 1956, Memorandum on the ground-water resources of the Leesville area, Vernon Parish, Louisiana: U.S. Geological Survey Open-File Report, 25 p. 
Maher, J.C., 1940, Ground-water resources of Rapides Parish, Louisiana: Louisiana Department of Conservation Geological Bulletin 17, 100 p.

Matthes, W. J., Jr., Sholar, C. J., and George, J. R., 1992, Quality-assurance plan for the analysis of fluvial sediment by laboratories of the U.S. Geological Survey: Open-File Report 91-467, 31 p.

McWreath, H.C., and Smoot, C.W., 1989, Geohydrology and development of ground water at Fort Polk, Louisiana: U.S. Geological Survey Water-Resources Investigations Report 88-4088, 53 p.

Meador, M.R., Hupp, C.R., Cuffney, T.F., and Gurtz, M.E., 1993, Methods for characterizing stream habitat as part of the National Water-Quality Assessment program: U.S. Geological Survey Open-File Report 93-408, 48 p.

Newbury, R.W., and Gaboury, M.N., 1993, Stream analysis and fish habitat design - a field manual: second printing 1994, $262 \mathrm{p}$.

Omernick, J.M., 1987, Ecoregions of the conterminous United States: Annals of the Association of American Geographers, v. 77, p. 118-125.

Rogers, J.E., and Calandro, A.J., 1965, Water resources of Vernon Parish, Louisiana: Department of Conservation, Louisiana Geological Survey, and Louisiana Department of Public Works Water Resources Bulletin no. 6, 104 p.

Rose, Arthur, Hawkes, Herbert, and Webb, John, 1979, Geochemistry in Mineral Exploration (2d ed.): Academic Press, [200] p.

Singh, V.P., 1992, Elementary Hydrology: New Jersey, Prentice-Hall, Inc., Englewood Cliffs, 973 p.

Sloss, Raymond, 1971, Drainage area of Louisiana streams: Louisiana Department of Public Works Basic Records Report no. 6, 117 p.

Sylvester, M.A., Kister, L.R., and Garrett, W.B., eds., 1990, Guidelines for the collection, treatment, and analysis of water samples--U.S. Geological Survey western region field manual: U.S. Geological Survey, $144 \mathrm{p}$.

Welch, R.N., 1942, Geology of Vernon Parish: Department of Conservation, Louisiana Geological Survey, Geological Bulletin No. 22, 90 p.

Whitfield, M.S., Jr., 1975, Geohydrology of the Evangeline and Jasper aquifers of southwestern Louisiana: Department of Conservation, Louisiana Geological Survey, and Louisiana Department of Public Works Water Resources Bulletin no. 20, 72 p. 


\section{Stream Characterization Forms}

Figures 12-25

\section{Explanation (adapted from Meador and others, 1993)}

[mm, millimeters; m, meters; cm, centimeters; sq km, square kilometers; sq mi, square miles; km, kilometers; $\mathrm{mi}$, miles; ft, feet; ft/sec, feet per second; in/yr, inches per year; , approximately]

\begin{tabular}{ll}
\hline ACPN & $\begin{array}{l}\text { Atchafalaya/Pontchartrain study unit } \\
\text { (nearest National Quality Water Assessment, or NAQWA, code to study area) }\end{array}$ \\
F.S. & Forest Service \\
Qth & Quaternary deposits, Pleistocene: High terraces \\
Mfb & Miocene deposits: Fleming Formation, Blounts Creek Member \\
LB & left bank \\
RB & right bank \\
CL & clay, generally less than $0.004 ;$ determined in field by feel and taste \\
SI & silt, generally fine material $0.004-0.06$ mm in diameter; determined in field by feel and taste \\
SA & sand, gritty material $0.06-2.0$ mm in diameter; determined in field by feel and ruler \\
SA/GR & mostly sand, with some gravel \\
SA/SI & mostly sand, with some silt \\
SI/SA & mostly silt, with some sand \\
GR & gravel, coarse material $2-64$ mm in diameter; determined in field with ruler \\
WD & woody debris and snags \\
OV & overhanging vegetation (terrestrial) \\
UB & undercut banks \\
ME & macrophytes-emergent (rooted to the bottom with parts extending above surface) \\
MA & macrophytes-submerged (grow under water, and depend on water column for support) \\
CC & bank description, concave upwards \\
CV & bank description, convex upwards \\
LN & bank description, linear bank \\
SCB & slightly cut bank scalloping \\
MCB & moderately cut bank scalloping \\
hd & hardwood trees, at least 2 m high and diameter at breast height of at least 3 cm \\
p & pine trees, at least $2 \mathrm{~m}$ high and diameter at breast height of at least $3 \mathrm{~cm}$ \\
sh & shrubs \\
\hline
\end{tabular}

\footnotetext{
${ }^{1}$ The bank's woody vegetation is listed in the reach characterization of the stream characterization form
} in order of relative abundance. 


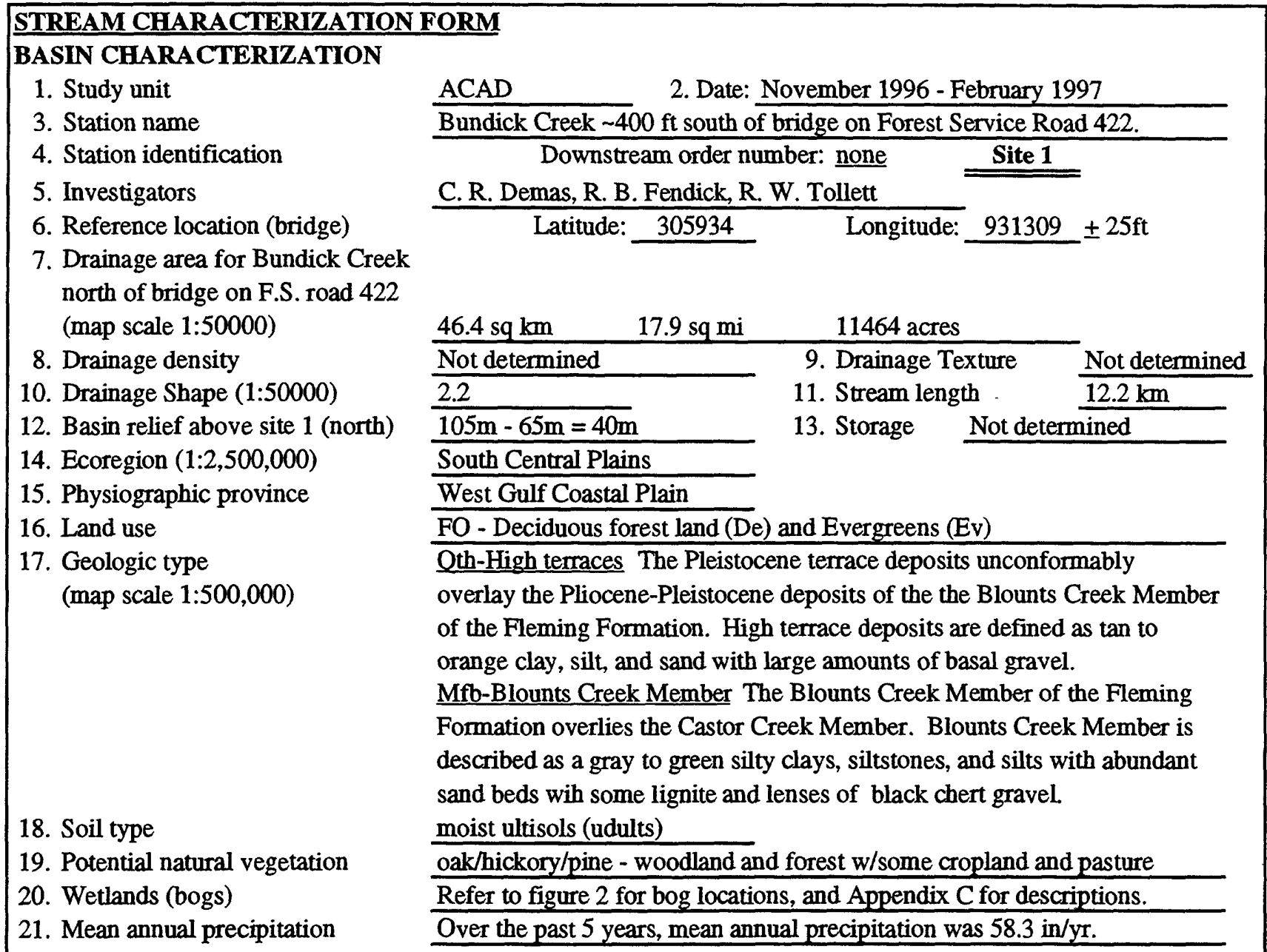

\section{SEGMENT CHARACTERIZATION}

1. Study unit

3. Station name

4. Station identification

5. Investigators

6. Reference location (bridge)

7. State

9. Township

11. Section

12. Quadrangle

13. Segment code

14. Segment length (1:50000)

15. Elevation of reference location

16. Sideslope gradient

17. Segment gradient

18. Channel sinuosity (1:50000)

19. Stream order

21. Water management feature
ACAD

Bundick Creek $\sim 400 \mathrm{ft}$ south of bridge on Forest Service Road 422. Downstream order number: none

C. R. Demas, R. B. Fendick, R. W. Tollett

Latitude: $305934 \quad$ Longitude: $931309 \pm 25 \mathrm{ft}$

Louisiana

$$
\text { 8. Parish Vernon }
$$

T.1S 10. Range R.8W

NE $1 / 4$, SE $1 / 4$, section 7

HURRICANE BRANCH QUADRANGLE - 7.5 Minute Series (Topographic) Not determined

Stream length above site 1 is $\sim 12.2 \mathrm{~km}$.

$217 \mathrm{ft}$ or $66 \mathrm{~m}$ (land surface elevation at bridge)

Not determined

0.0033

$\frac{1.7}{\text { None }}$

20. Downstream link 3

Figure 12. Stream characterization form for site 1 in the Limited Use Area, Vernon Ranger

District, Kisatchie National Forest, Louisiana. 


\section{FIRST-LEVEL REACH CHARACTERIZATION}

1. Study unit

3. Station name

4. Station identification

5. Investigators

6. Reference location (bridge)

7. Reference location description

8. Upstream reach boundary (T1) nearest to reference location

9. Channel width at center transect

10. Geomorphic channel units

12. Stream type
$\mathrm{ACAD}$

2. Date:

Wed, March 12, 1997

Bundick Creek $\sim 400 \mathrm{ft}$ south of bridge on Forest Service Road 422. Downstream order number: none Site 1

R. B. Fendick/R. W. Tollett

\begin{tabular}{|c|c|c|c|}
\hline Latitude: & 305934 & Longitude: & 931309 \\
\hline $\begin{array}{r}\text { Weather Conditions: } \\
\text { Stage: }\end{array}$ & $\begin{array}{l}\text { light rain } \\
\text { stable }\end{array}$ & Time: & 0730 \\
\hline
\end{tabular}

middle bridge of three on Forest Service Road 422

about $325 \mathrm{ft}$ downstream from the reference location

\begin{tabular}{|c|c|c|}
\hline none & 11. Reach length: & $150 \mathrm{ft}$ \\
\hline
\end{tabular}

Transects

13. Distance from center of reach $(\mathrm{ft}) 75$

Upstream - T1

14. Channel width (ft)

15. Bank width (ft)

no data

Center - T2

\begin{tabular}{l}
$\frac{\text { Center }-\mathrm{T}}{0}$ \\
\hline no data \\
\hline $\mathrm{LB}>50 \mathrm{~m}, \mathrm{RB}>50 \mathrm{~m}$
\end{tabular}

Downstream - T3

16. Flood-plain width

Center Transect - T2 Latitude 305930 Longitude $931307 \pm 40 \mathrm{ft}$

Distances from left bank edge.

17. Depth (feet)

18. Velocity $(\mathrm{ft} / \mathrm{s})$

19. Bed substrate

20. Embeddedness

$\frac{\frac{\mathrm{LB}}{0} \frac{3.5}{\frac{0}{\mathrm{SA}}} \frac{2.8}{0.952}}{\frac{\mathrm{SA}}{0 \text { (none) }}}$

\begin{tabular}{|c|c|c|}
\hline 7.0 & $\overline{10.5}$ & $\overline{\mathrm{RB}}$ \\
\hline 2.9 & 1.0 & $\overline{0}$ \\
\hline 0.864 & 0.750 & $\overline{0}$ \\
\hline SA & $\overline{S A}$ & $\overline{S A}$ \\
\hline 0 (none) & 0 (none) & 0 (none) \\
\hline
\end{tabular}

Transects

21. Canopy angle (degrees)

22. Aspect (azimuth - 360 degrees)

23. Habitat features

24. Bar/shelf/island

LB-left bank/RB-right bank

25. Bank angle (degrees)

26. Bank height ( $\mathrm{ft}$ )

27. Bank vegetation stability

28. Bank shape

29. Bank erosion

30. Bank substrate

31. Woody vegetation

Upstream - T1

150

WD, OV, UB, ME

none

\begin{tabular}{l|l}
\hline $\mathrm{LB}$ & $\mathrm{RB}$ \\
$\frac{115}{5.5}$ & $\frac{105}{5.5}$ \\
$\frac{3}{\mathrm{CC}}$ & $\frac{3}{\mathrm{CC}}$ \\
$\frac{\mathrm{SCB}}{\mathrm{SA} / \mathrm{SI}}$ & $\frac{\mathrm{SCB}}{\mathrm{hd} / \mathrm{sh}}$ \\
$\frac{\mathrm{SASI}}{\mathrm{hd} / \mathrm{sh}}$
\end{tabular}

Center - T2

Downstream - T3

10

190

WD, UB, MA

none

$\frac{\mathrm{LB}}{105}$

$\frac{105}{6.0}$

$\frac{6.0}{3}$

3

$\mathrm{MCB}$

SAS

75

16

no data

32. Photodocumentation

(center transect)

33. Diagrammatic map

none

refer to following page

$\frac{\frac{\text { Downstream - T3 }}{<5}}{\frac{165}{\mathrm{WD}, \mathrm{OV}, \mathrm{UB}}}$
$\frac{\mathrm{none}}{\mathrm{LB}}$
$\frac{155}{6.0} \frac{\mathrm{RB}}{\frac{105}{5}} \frac{5.5}{3}$
$\frac{\mathrm{LN}}{\mathrm{Lone}} \frac{\mathrm{CC}}{\mathrm{MCB}}$
$\frac{\text { SA/SI }}{\mathrm{hd}} \frac{\mathrm{SA} / \mathrm{SI}}{\mathrm{sh} / \mathrm{hd}}$

34. Aquatic and riparian vegetation species - Refer to Appendicies B and C.

35. Comments

abundance of cypress trees/bamboo common on banks

secchi disk (light penetration) $=2.8 \mathrm{ft}$

\section{SECOND-LEVEL REACH CHARACTERIZATION}

Microhabitat characterization

Benthic invertabrate communities Refer to work in Appendix B by Dr. Vidrine.

Fish communities Refer to previous work.

Figure 12. Stream characterization form for site 1 in the Limited Use Area, Vernon Ranger

District, Kisatchie National Forest, Louisiana--Continued. 


\section{SITE SKETCH}

Site 1. Bundick Creek $\sim 400 \mathrm{ft}$ south of bridge on Forest Service Road 422.

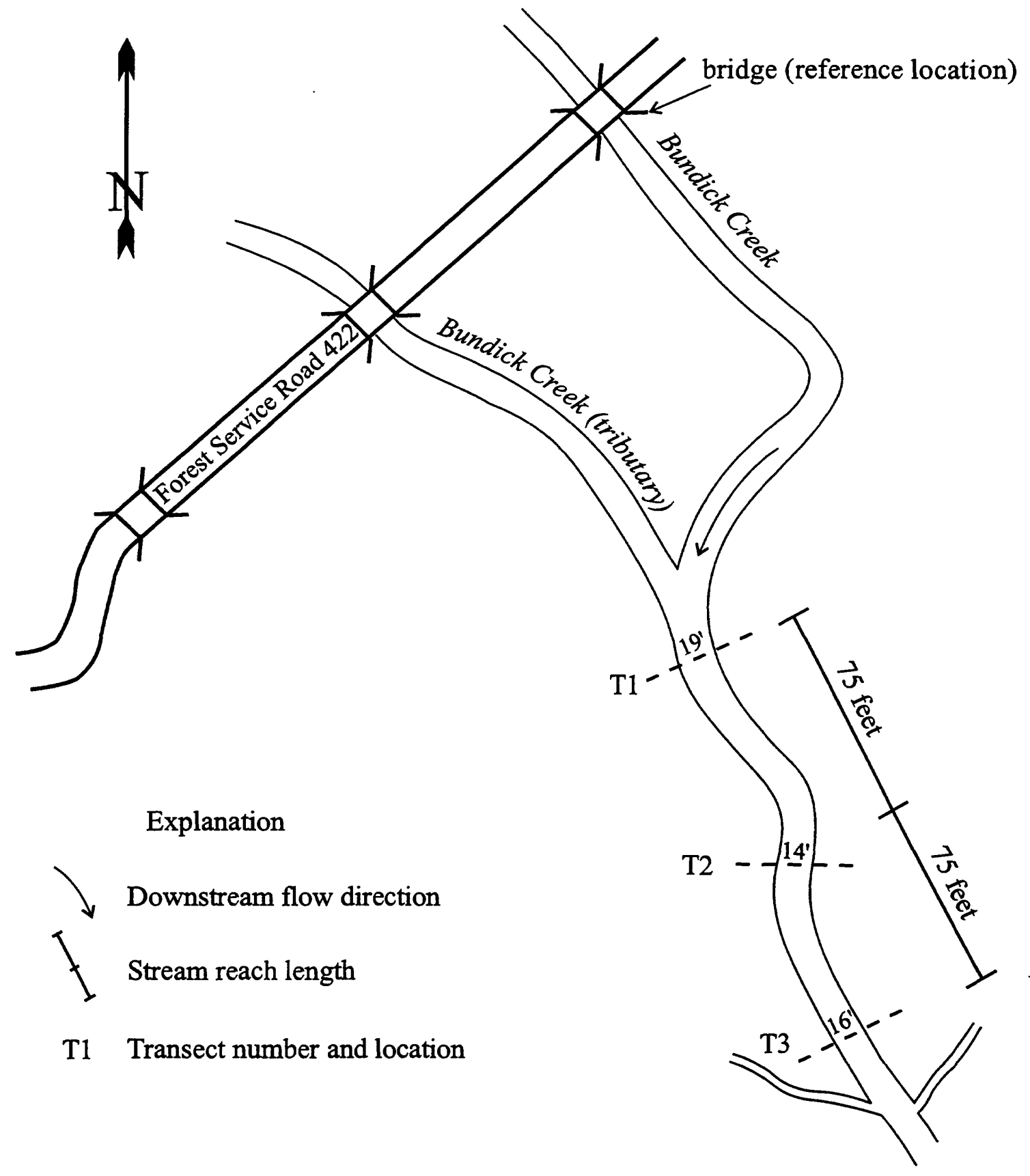

NOT DRAWN TO SCALE

Figure 12. Stream characterization form for site 1 in the Limited Use Area, Vernon Ranger District, Kisatchie National Forest, Louisiana--Continued. 


\section{STREAM CHARACTERIZATION FORM}

\section{BASIN CHARACTERIZATION}

1. Study unit

3. Station name

4. Station identification

5. Investigators

6. Reference location (bridge)

7. Drainage area for Bundick Creek north of bridge on F.S. road 410

(map scale 1:50000)

8. Drainage density

10. Drainage Shape (1:50000)

12. Basin relief above site 2 (north)

14. Ecoregion $(1: 2,500,000)$

15. Physiographic province

16. Land use

17. Geologic type

(map scale 1:500,000)

18. Soil type

19. Potential natural vegetation

20. Wetlands (bogs)

21. Mean annual precipitation
ACAD

2. Date: November 1996 - February 1997

Bundick Creek $200 \mathrm{ft}$ north of bridge on Forest Service Road 410.

Downstream order number: none

C. R. Demas, R. B. Fendick, R. W. Tollett

Site 2

Latitude: 305630

Longitude: $931208 \pm 20 \mathrm{ft}$

$77.3 \mathrm{sq} \mathrm{km} \quad 29.8 \mathrm{sq} \mathrm{mi}$ 19094 acres

Not determined
$\frac{7.0}{105 \mathrm{~m}-55 \mathrm{~m}=50 \mathrm{~m}}$
South Central Plains

9. Drainage Texture Not determined

11. Stream length $20.1 \mathrm{~km}$

13. Storage Not determined

West Gulf Coastal Plain

FO - Deciduous forest land (De) and Evergreens (Ev)

Qth-High terraces The Pleistocene terrace deposits unconformably overlay the Pliocene-Pleistocene deposits of the the Blounts Creek Member of the Fleming Formation. High terrace deposits are defined as tan to orange clay, silt, and sand with large amounts of basal gravel.

Mfb-Blounts Creek Member The Blounts Creek Member of the Fleming

Formation overlies the Castor Creek Member. Blounts Creek Member is described as a gray to green silty clays, siltstones, and silts with abundant sand beds wih some lignite and lenses of black chert gravel.

moist ultisols (udults)

oak/hickory/pine - woodland and forest w/some cropland and pasture

Refer to figure 2 for bog locations, and Appendix $\mathrm{C}$ for descriptions.

Over the past 5 years, mean annual precipitation was 58.3 in/yr.

\section{SEGMENT CHARACTERIZATION}

1. Study unit

3. Station name

4. Station identification

5. Investigators

6. Reference location (bridge)

7. State

9. Township

11. Section

12. Quadrangle

13. Segment code

14. Segment length (1:50000)

15. Elevation of reference location

16. Sideslope gradient

17. Segment gradient

18. Channel sinuosity (1:50000)

19. Stream order

21. Water management feature
$\mathrm{ACAD}$

2. Date: November 1996 - February 1997

Bundick Creek $200 \mathrm{ft}$ north of bridge on Forest Service Road 410. Downstream order number: none

C. R. Demas, R. B. Fendick, R. W. Tollett

Latitude: $\frac{305630}{8}$ Longitude: $931208 \pm 20 \mathrm{ft}$

Louisiana 8. Parish Vemon

T.1S 10. Range R.8W

SE $1 / 4$, SE $1 / 4$, section 29

HURRICANE BRANCH QUADRANGLE - 7.5 Minute Series (Topographic)

Not determined

Stream length above site 2 is $\sim 20.0 \mathrm{~km}$.

$178 \mathrm{ft}$ or $54 \mathrm{~m}$ (land surface elevation at bridge)

Not determined

0.0025

1.6

20. Downstream link 3

None

Figure 13. Stream characterization form for site 2 in the Limited Use Area, Vernon Ranger District, Kisatchie National Forest, Louisiana. 


\section{FIRST-LEVEL REACH CHARACTERIZATION}

1. Study unit

3. Station name

4. Station identification

5. Investigators

6. Reference location (bridge)

7. Reference location description

8. Downstream reach boundary
ACAD 2. Date: Tues, March 11, 1997

Bundick Creek $\sim 200 \mathrm{ft}$ north of bridge on Forest Service Road 410

Downstream order number: none

R. B. Fendick/R. W. Tollett

Latitude: $\frac{305630}{\text { congitude: } \quad 931208} \pm 20 \mathrm{ft}$

Weather Conditions: $\frac{30 u d y}{12 \text { cloud }} 1500$

Stage: $1 / 2$ bank full, cresting

concrete bridge on partial blacktop road

(T3) nearest to reference location about 100ft upstream from the reference location

9. Channel width at center transect $15 \mathrm{ft} \times 10(20$ recommended $)=$ reach length

10. Geomorphic channel units

12. Stream type

none 11. Reach length: $150 \mathrm{ft}$
meandering/actively cutting banks

Transects

Upstream - T1

13. Distance from center of reach $(\mathrm{ft})$

14. Channel width (ft)

15. Bank width ( $\mathrm{ft}$ )

no data

16. Flood-plain width

Center Transect - T2 Latitude 305631 Longitude $931205 \pm 41 \mathrm{ft}$

Distances from left bank edge.

17. Depth (feet)

18. Velocity $(\mathrm{ft} / \mathrm{s})$

19. Bed substrate

20. Embeddedness
Center - T2

0

15

no data

$\mathrm{LB}>50 \mathrm{~m}, \mathrm{RB}>50 \mathrm{~m}$

$\begin{array}{lll}7.5 & 1125 & \text { RB }\end{array}$

Downstream - T3

17

no data

\begin{tabular}{|c|c|}
\hline LB & 3.75 \\
\hline 0 & 2.3 \\
\hline$\overline{0}$ & 1.419 \\
\hline$\overline{\mathrm{SA}}$ & $\overline{\mathrm{SA}}$ \\
\hline 0 (none) & 0 (none) \\
\hline
\end{tabular}

$\frac{\frac{2.2}{1.186}}{\frac{\text { coarse SA }}{0 \text { (none) }}}$

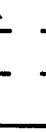

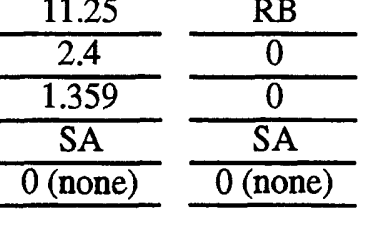

Transects

Upstream - T1

75

21. Canopy angle (degrees)

22. Aspect (azimuth - 360 degrees)

23. Habitat features

24. Bar/shelf/island

LB-left bank/RB-right bank

25. Bank angle (degrees)

26. Bank height ( $\mathrm{ft}$ )

27. Bank vegetation stability

28. Bank shape

29. Bank erosion

30. Bank substrate

31. Woody vegetation

32. Photodocumentation

(center transect)

33. Diagrammatic map

Center - T2

Downstream - T3

180

0

WD, OV

LB - bar

LB

160

6.0

2

$\mathrm{CC}$

none

SA/SI

p/hd/grass

RB

115

6.5

2

$\mathrm{CV}$

195

15

WD

none

LB

120

7.0

3

$\mathrm{CV}$

$\mathrm{MCB}$

MCB

SA/SI

SA

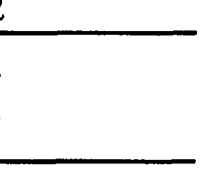

210

WD

none

LB

$\frac{\mathrm{RB}}{140}$

$\frac{140}{7.0}$

2

LN

$\frac{\mathrm{LB}}{150}$

6.0

3

CV

none

none

hd/grass

SA

hd

hd/sh

none

refer to following page

34. Aquatic and riparian vegetation species - Refer to Appendicies B and C.

35. Comments

abundance of cypress trees and cypress knees along banks

secchi disk (light penetration) $=2.7 \mathrm{ft}$

\section{SECOND-LEVEL REACH CHARACTERIZATION}

Microhabitat characterization

Benthic invertabrate communities Refer to work in Appendix B by Dr. Vidrine.

Fish communities

Refer to previous work.

Figure 13. Stream characterization form for site 2 in the Limited Use Area, Vernon Ranger

District, Kisatchie National Forest, Louisiana--Continued. 


\section{SITE SKETCH}

Site 2. Bundick Creek $\sim 200 \mathrm{ft}$ north of bridge on Forest Service Road 410.

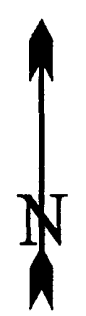

Explanation

$\searrow$ Downstream flow direction

f Stream reach length

T1 Transect number and location

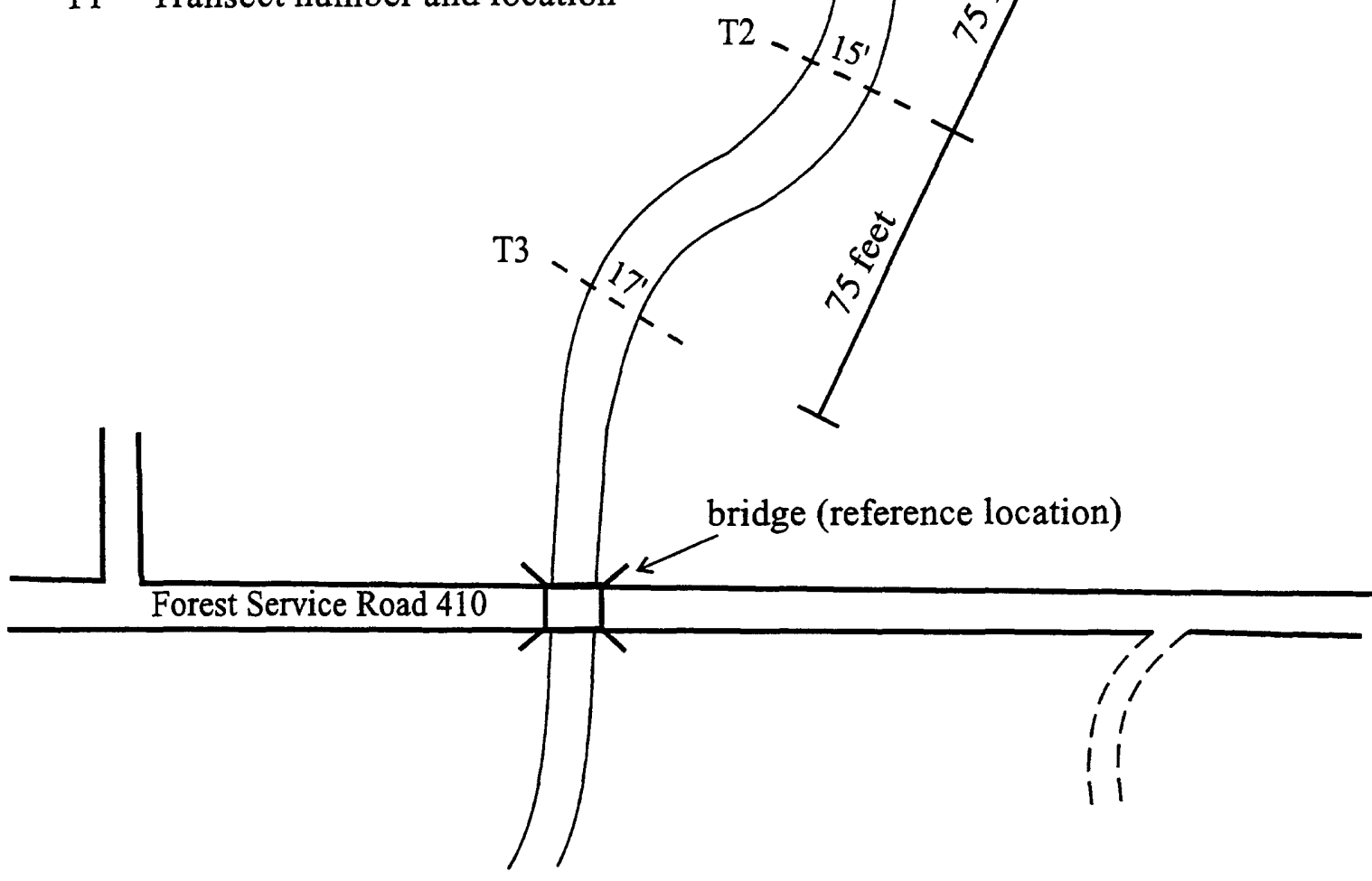

NOT DRAWN TO SCALE

Figure 13. Stream characterization form for site 2 in the Limited Use Area, Vernon Ranger District, Kisatchie National Forest, Louisiana--Continued. 


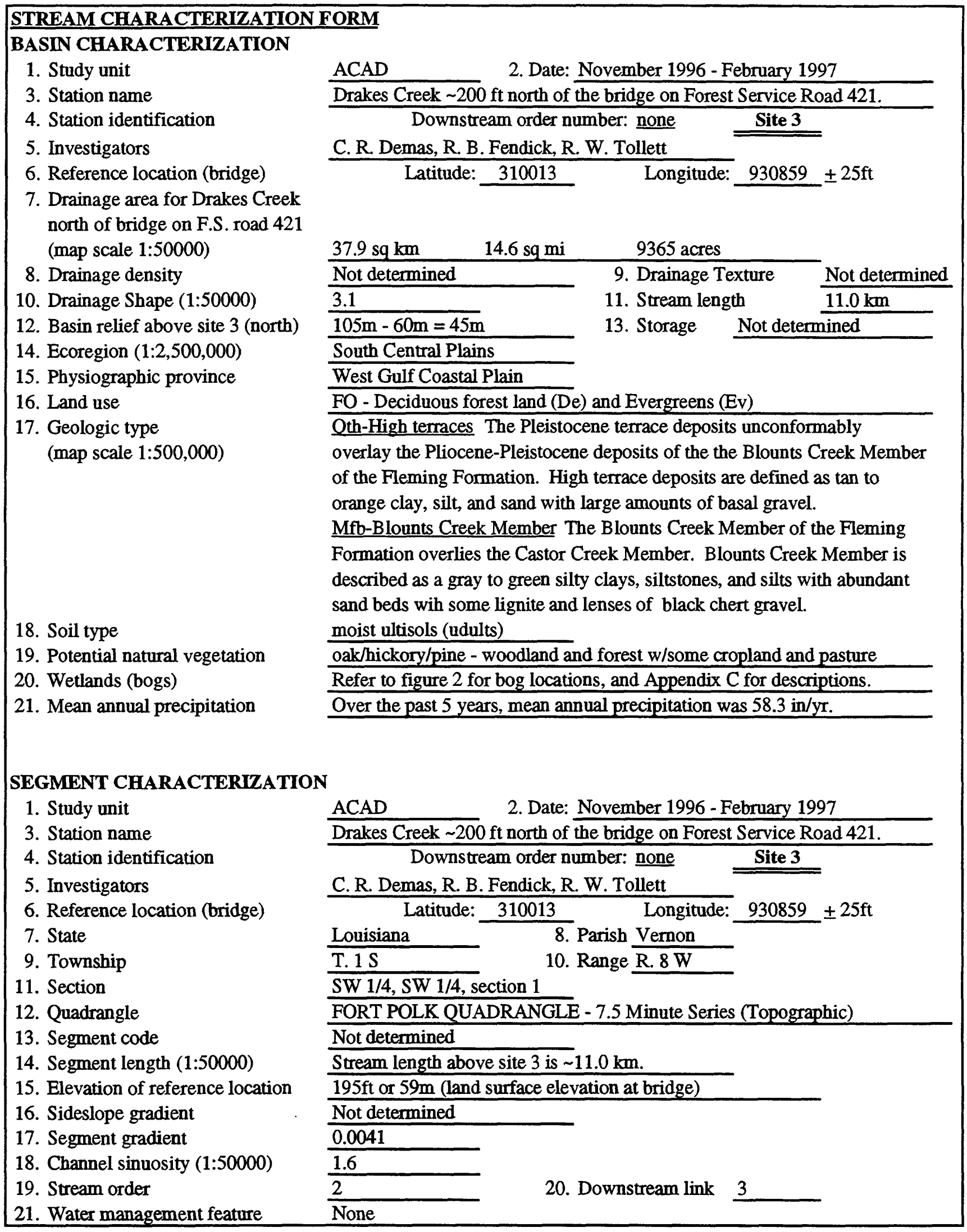

Figure 14. Stream characterization form for site 3 in the Limited Use Area, Vernon Ranger District, Kisatchie National Forest, Louisiana. 


\section{FIRST-LEVEL REACH CHARACTERIZATION}

1. Study unit

3. Station name

4. Station identification

5. Investigators

6. Reference location (bridge)

7. Reference location description

8. Downstream reach boundary
$\mathrm{ACAD}$

2. Date:

Wed, March 12, 1997

Drakes Creek $200 \mathrm{ft}$ north of the bridge on Forest Service Road 421.

Downstream order number: none

Site 3

R. B. Fendick/R. W. Tollett

Latitude: $\quad 310013$ Longitude: $\frac{930859}{1230} \pm 25 \mathrm{ft}$

Weather Conditions: light rain $\quad$ Time: 1230

Stage: $1 / 3$ bank full, stable

concrete bridge on unimproved road, F.S. Road 421

(T3) nearest to reference location about $100 \mathrm{ft}$ upstream from the reference location

9. Channel width at center transect $20 \mathrm{ft} \times 10(20$ recommended $)=$ reach length

10. Geomorphic channel units

none

11. Reach length: $200 \mathrm{ft}$

12. Stream type

meandering/actively cutting banks

Transects

13. Distance from center of reach ( $\mathrm{ft}$ )

Upstream - T1

14. Channel width (ft)

15. Bank width (ft)

15

16. Flood-plain width

\section{Center - T2}

0

20

no data

$\mathrm{LB}>50 \mathrm{~m}, \mathrm{RB}>50 \mathrm{~m}$
Downstream - T3

100

21

no data

Latitude 310013 Longitude $930901 \pm 21 \mathrm{ft}$

Center Transect - T2

Distances from left bank edge.

17. Depth (feet)

18. Velocity $(\mathrm{ft} / \mathrm{s})$

19. Bed substrate

20. Embeddedness

$\frac{\frac{\mathrm{LB}}{0} \frac{5.0}{\frac{0}{\mathrm{SA}}} \frac{1.2}{\frac{1.068}{\mathrm{SA}}}}{\frac{0 \text { (none) }}{0 \text { (none) }}}$

\begin{tabular}{|c|c|c|}
\hline 10.0 & 15.0 & $\overline{\mathrm{RB}}$ \\
\hline 0.8 & $\overline{0.9}$ & $\overline{0}$ \\
\hline 0.979 & 0.887 & $\overline{0}$ \\
\hline$\overline{\mathrm{SA}}$ & $\overline{\mathrm{SA}}$ & $\overline{\mathrm{SA}}$ \\
\hline 0 (none) & 0 (none) & 0 (none) \\
\hline
\end{tabular}

21. Canopy angle (degrees)

22. Aspect (azimuth - 360 degrees)

23. Habitat features

24. Bar/shelf/island

LB-left bank/RB-right bank

25. Bank angle (degrees)

26. Bank height ( $\mathrm{ft}$ )

27. Bank vegetation stability

28. Bank shape

29. Bank erosion

30. Bank substrate

31. Woody vegetation

32. Photodocumentation

(center transect)

33. Diagrammatic map

0

115

OV, WD, UB, ME

none

LB

155

8.0

3

LN

none

SI/CL/SA

$\mathrm{hd} / \mathrm{sh} \quad \frac{\mathrm{hd} / \mathrm{sh} / \mathrm{p}}{\mathrm{S}}$

Center - T2

0

100

OV, WD, UB

none

LB

100

5.5

$\frac{90}{8.5}$

8.5

3

LN

MCB

SI/SA

3

$\mathrm{CV}$

$\mathrm{SCB}$

SI/CL/SA

$\mathrm{hd} / \mathrm{p} / \mathrm{sh}$

\begin{tabular}{|c|c|}
\hline Downstrean & $1-\mathrm{T} 3$ \\
\hline 0 & \\
\hline 110 & \\
\hline$\overline{\mathrm{OV}, \mathrm{WD}, \mathrm{U}}$ & \\
\hline none & \\
\hline$\overline{\mathrm{LB}}$ & $\mathrm{RB}$ \\
\hline 110 & 135 \\
\hline 6.0 & 6.5 \\
\hline 3 & 3 \\
\hline $\mathrm{CC}$ & $\overline{\mathrm{CC}}$ \\
\hline$\overline{\mathrm{MCB}}$ & none \\
\hline SI/CL/SA & $\overline{\mathrm{SI} / \mathrm{CL} / \mathrm{SA}}$ \\
\hline $\mathrm{hd} / \mathrm{sh}$ & $h d / s h$ \\
\hline
\end{tabular}

34. Aquatic and riparian vegetation species - Refer to Appendicies B and C.

35. Comments

none

refer to following page

numerous mussels found on bottom of stream at all 3 transects

secchi disk (light penetration) $=>2.0 \mathrm{ft}$

\section{SECOND-LEVEL REACH CHARACTERIZATION}

Microhabitat characterization

Benthic invertabrate communities Refer to work in Appendix B by Dr. Vidrine.

Fish communities Refer to previous work.

Figure 14. Stream characterization form for site 3 in the Limited Use Area, Vernon Ranger

District, Kisatchie National Forest, Louisiana--Continued. 


\section{SITE SKETCH}

Site 3. Drakes Creek $200 \mathrm{ft}$ north of bridge on Forest Service Road 421.
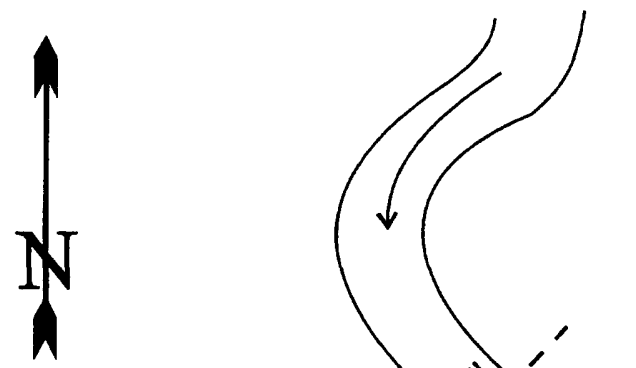

\section{Explanation}

Downstream flow direction

Stream reach length

T1 Transect number and location

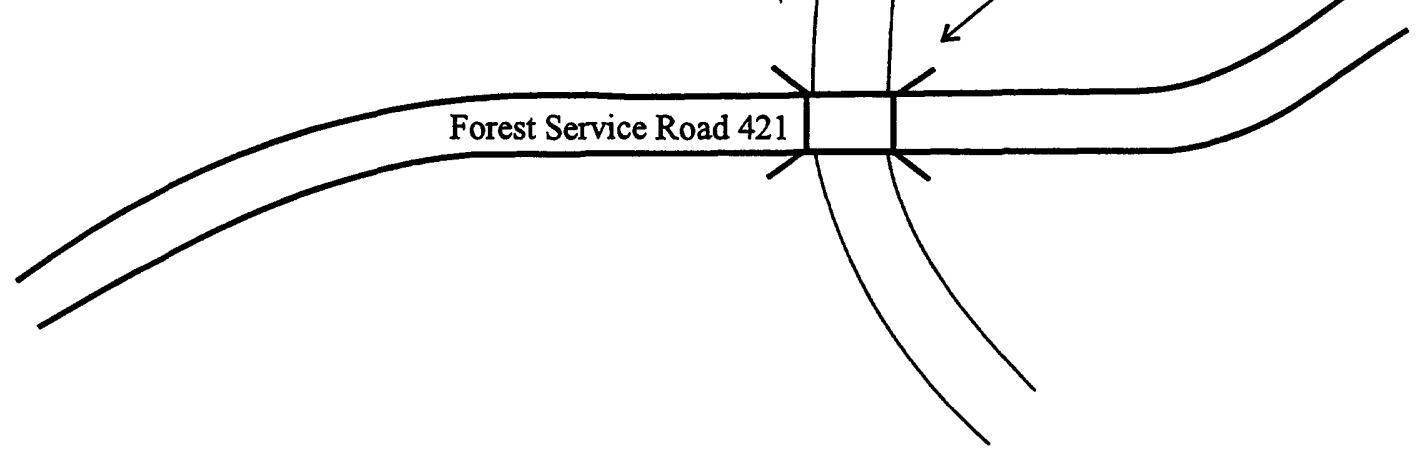

NOT DRAWN TO SCALE

Figure 14. Stream characterization form for site 3 in the Limited Use Area, Vernon Ranger District, Kisatchie National Forest, Louisiana--Continued. 


\section{STREAM CHARACTERIZATION FORM}

\section{BASIN CHARACTERIZATION}

1. Study unit

3. Station name

4. Station identification

5. Investigators

6. Reference location (bridge)

7. Drainage area for Drakes Creek north of bridge on LA hwy 10 (map scale 1:50000)

8. Drainage density

10. Drainage Shape (1:50000)

12. Basin relief above site 4 (north)

14. Ecoregion $(1: 2,500,000)$

15. Physiographic province

16. Land use

17. Geologic type (map scale 1:500,000)

18. Soil type

19. Potential natural vegetation

20. Wetlands (bogs)

21. Mean annual precipitation
$\mathrm{ACAD}$

2. Date: November 1996 - February 1997

Drakes Creek $\sim 400 \mathrm{ft}$ north of the bridge on Louisiana Highway 10 . Downstream order number: none Site 4

C. R. Demas, R. B. Fendick, R. W. Tollett

$930818 \pm 39 \mathrm{ft}$

\begin{tabular}{|c|c|c|}
\hline \multirow{2}{*}{$\begin{array}{l}55.5 \mathrm{sq} \mathrm{km} \\
\text { Not determined }\end{array}$} & 13707 acres & \\
\hline & 9. Drainage Texture & Not determine \\
\hline 4.3 & \multicolumn{2}{|l|}{ 11. Stream length . } \\
\hline $105 \mathrm{~m}-55 \mathrm{~m}=50 \mathrm{~m}$ & 13. Storage Not d & Not determined \\
\hline \multicolumn{3}{|l|}{ South Central Plains } \\
\hline \multicolumn{3}{|l|}{ West Gulf Coastal Plain } \\
\hline \multicolumn{3}{|c|}{ FO - Deciduous forest land (De) and Evergreens (Ev) } \\
\hline \multicolumn{3}{|c|}{$\begin{array}{l}\text { Qth-High terraces The Pleistocene terrace deposits unconformably } \\
\text { overlay the Pliocene-Pleistocene deposits of the the Blounts Creek Member } \\
\text { of the Fleming Formation. High terrace deposits are defined as tan to } \\
\text { orange clay, silt, and sand with large amounts of basal gravel. } \\
\text { Mfb-Blounts Creek Member The Blounts Creek Member of the Fleming }\end{array}$} \\
\hline \multicolumn{3}{|c|}{$\begin{array}{l}\text { Formation overlies the Castor Creek Member. Blounts Creek Member is } \\
\text { described as a gray to green silty clays, siltstones, and silts with abundant } \\
\text { sand beds wih some lignite and lenses of black chert gravel. } \\
\text { moist ultisols (udults) } \\
\text { oak/hickory/pine - woodland and forest w/some cropland and pasture }\end{array}$} \\
\hline fer to figure 2 for bog locati & & \\
\hline
\end{tabular}

Latitude: $305748 \quad$ Longitude: $930818 \pm 39 \mathrm{ft}$

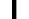

\section{SEGMENT CHARACTERIZATION}

1. Study unit

3. Station name

4. Station identification

5. Investigators

6. Reference location (bridge)

7. State

9. Township

11. Section

12. Quadrangle

13. Segment code

14. Segment length (1:50000)

15. Elevation of reference location

16. Sideslope gradient

17. Segment gradient

18. Channel sinuosity (1:50000)

19. Stream order

21. Water management feature

Figure 15. Stream characterization form for site 4 in the Limited Use Area, Vernon Ranger District, Kisatchie National Forest, Louisiana. 
FIRST-LEVEL REACH CHARACTERIZATION
1. Study unit
3. Station name
4. Station identification
5. Investigators
6. Reference location (bridge)

7. Reference location description

8. Downstream reach boundary
$\mathrm{ACAD}$

2. Date: Tues, March 11, 1997

Drakes Creek $\sim 400 \mathrm{ft}$ north of the bridge on Louisiana Highway 10. Downstream order number: none

R. B. Fendick/R. W. Tollett

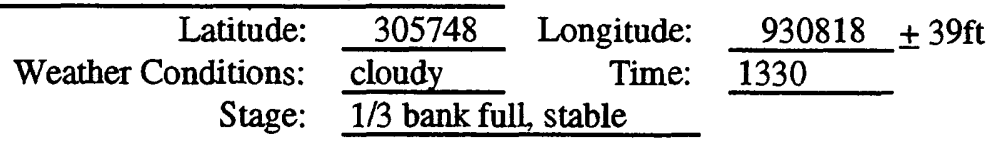

concrete bridge on LA. Highway 10

Site 4

(T3) nearest to reference location about $300 \mathrm{ft}$ upstream from the reference location

9. Channel width at center transect $20 \mathrm{ft} \times 10(20$ recommended $)=$ reach length

10. Geomorphic channel units

12. Stream type

\begin{tabular}{ll}
\hline none 11. Reach length: $200 \mathrm{ft}$ \\
meandering/actively cutting banks
\end{tabular}

Transects

13. Distance from center of reach $(\mathrm{ft})$

14. Channel width (ft)

15. Bank width (ft)

16. Flood-plain width

\begin{tabular}{l}
\hline Distances from left bank edge. \\
17. Depth (feet) \\
18. Velocity $(\mathrm{ft} / \mathrm{s})$ \\
19. Bed substrate \\
20. Embeddedness
\end{tabular}

21. Canopy angle (degrees)

22. Aspect (azimuth - 360 degrees)

23. Habitat features

24. Bar/shelf/island

LB-left bank/RB-right bank

25. Bank angle (degrees)

26. Bank height ( $\mathrm{ft}$ )

27. Bank vegetation stability

28. Bank shape

29. Bank erosion

30. Bank substrate

31. Woody vegetation

32. Photodocumentation

(center transect)

33. Diagrammatic map
Upstream - T1

Center - T2

100

no data

0

18

no data

$\mathrm{LB}>50 \mathrm{~m}, \mathrm{RB}>50 \mathrm{~m}$

Center Transect - T2 Latitude 305752 Longitude $930817 \pm 30 \mathrm{ft}$

\begin{tabular}{|c|c|}
\hline$\overline{\mathrm{LB}}$ & 4.5 \\
\hline$\overline{0}$ & 2.0 \\
\hline$\overline{0}$ & 0.835 \\
\hline$\overline{\mathrm{SA}}$ & $\overline{\mathrm{SA}}$ \\
\hline 0 (none) & 0 (none) \\
\hline
\end{tabular}

\begin{tabular}{|c|c|}
\hline 9.0 & 13.5 \\
\hline 1.8 & 1.5 \\
\hline 1.305 & 1.099 \\
\hline$\overline{\mathrm{SA}}$ & $\overline{\mathrm{SA}}$ \\
\hline 0 (none) & 0 (none) \\
\hline
\end{tabular}

$\frac{\mathrm{RB}}{\frac{0}{0}}$

Downstream - T3

100

22

no data

Center - T2

Upstream - T1

65

140

OV, UB, ME

LB - point bar

LB

$\underline{135}-140$

$\frac{135}{3.0}-\frac{140}{3.5}$

$\frac{6}{3}-\frac{7}{3}$

$\overline{\mathrm{CV}} \mathrm{CC}$

SCB

SA/SI

$\mathrm{SCB}$

$\mathrm{hd} / \mathrm{sh} / \mathrm{p}$

SA/SI

35

170

OV, WD

none

LB

6.0

LN

SCB

SA/SI

$\mathrm{hd} / \mathrm{sh} / \mathrm{p}$

Downstream - T3

30

270

OV, WD, UB

$\mathrm{RB}$ - point bar

LB RB

$120 \quad 145$

7.0

3

3

LN

none

SA/SI

$\mathrm{hd} / \mathrm{sh} / \mathrm{p}$ 6.0

3

$\mathrm{CV}$

SCB

3

$\mathrm{CC}$

SA/SI none hd/p/sh hd/sh SA/SI

34. Aquatic and riparian vegetation species - Refer to Appendicies B and C.

35. Comments

none

refer to following page

bamboo on banks of center transects

secchi disk (light penetration) $=2.4 \mathrm{ft}$

\section{SECOND-LEVEL REACH CHARACTERIZATION}

Microhabitat characterization

Benthic invertabrate communities Refer to work in Appendix B by Dr. Vidrine.

Fish communities

Refer to previous work.

Figure 15. Stream characterization form for site 4 in the Limited Use Area, Vernon Ranger

District, Kisatchie National Forest, Louisiana--Continued. 


\section{SITE SKETCH}

Site 4. Drakes Creek $300 \mathrm{ft}$ north of bridge on Louisiana Highway 10.

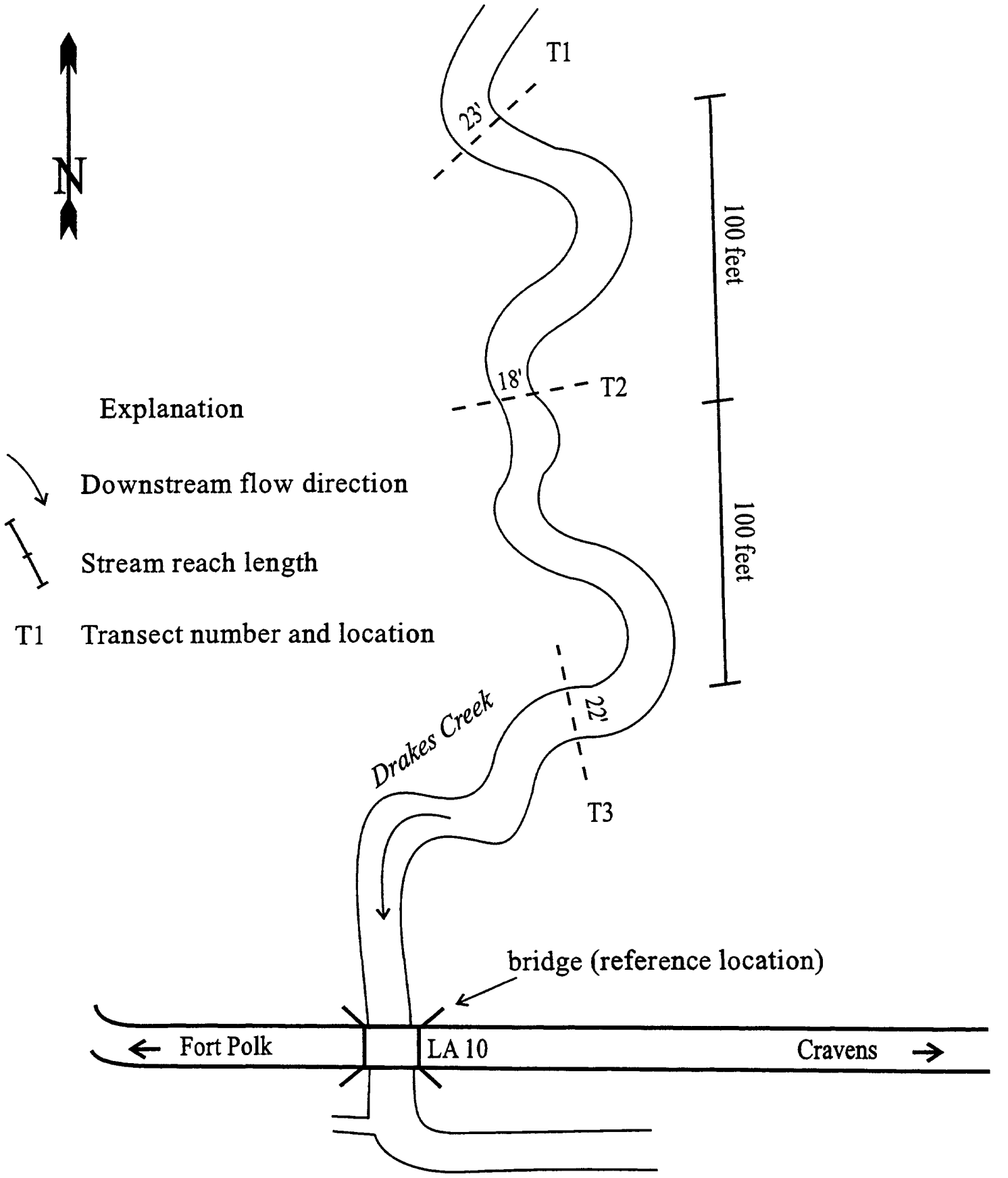

NOT DRAWN TO SCALE

Figure 15. Stream characterization form for site 4 in the Limited Use Area, Vernon Ranger District, Kisatchie National Forest, Louisiana--Continued. 


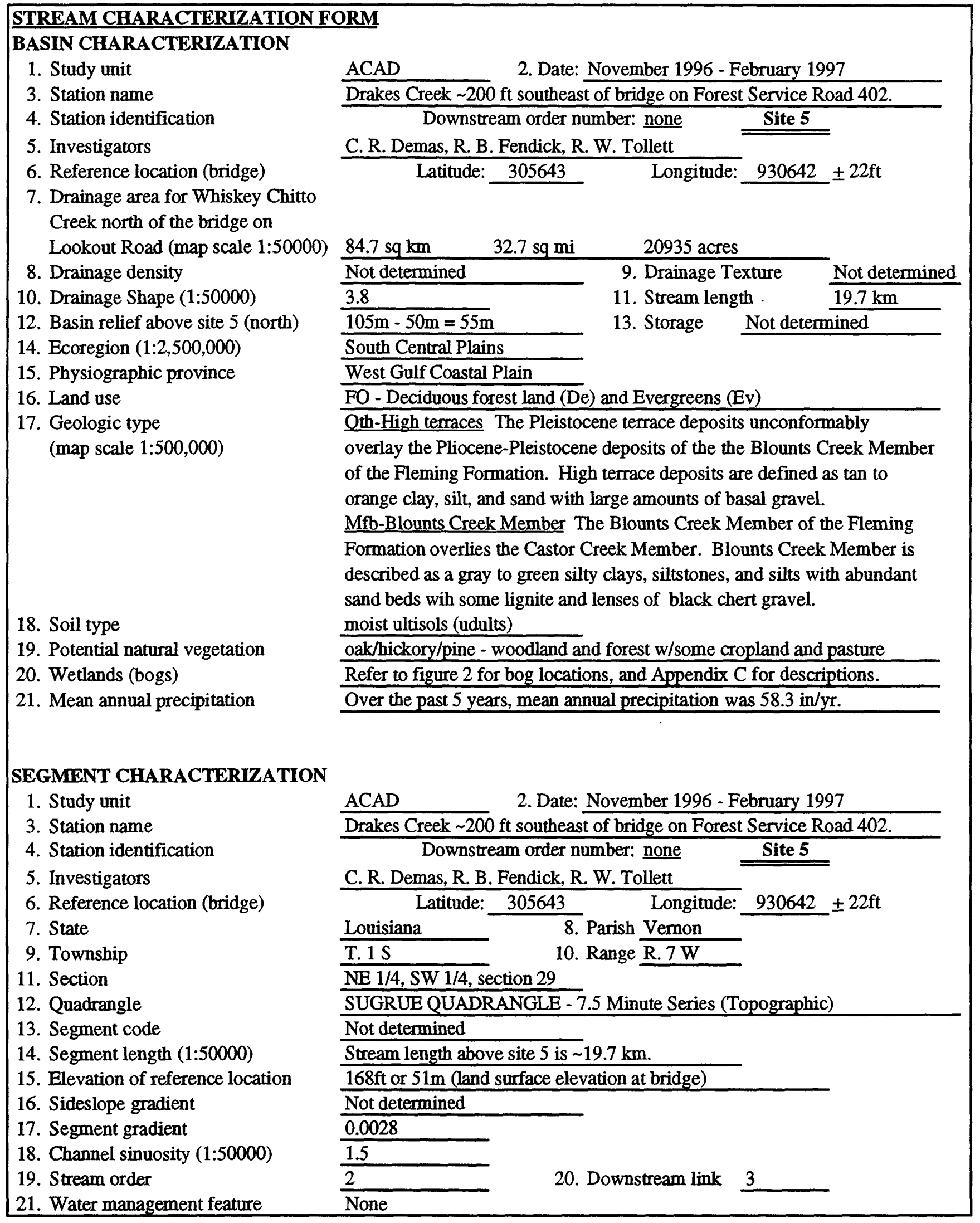

Figure 16. Stream characterization form for site 5 in the Limited Use Area, Vernon Ranger District, Kisatchie National Forest, Louisiana. 


\section{FIRST-LEVEL REACH CHARACTERIZATION}

1. Study unit

3. Station name

4. Station identification

5. Investigators

6. Reference location (bridge)

7. Reference location description

8. Upstream reach boundary (T1) nearest to reference location

9. Channel width at center transect

10. Geomorphic channel units

12. Stream type
2. Date: Tues, March 11, 1997

Drakes Creek $\sim 200 \mathrm{ft}$ southeast of bridge on Forest Service Road 402.

Downstream order number: none

Site 5

R. B. Fendick/R. W. Tollett

Latitude: $\underline{305643}$ Longitude: $\underline{930642} \pm 22 \mathrm{ft}$

Weather Conditions: cloudy Time: 1200

Stage: $1 / 2$ bank full, rising

concrete bridge off unimproved road, F.S. Road 402

about $100 \mathrm{ft}$ downstream from the reference location

$15 \mathrm{ft} \times 10$ (20 recommended $)=$ reach length

none 11 . Reach length: $150 \mathrm{ft}$
meandering/actively cutting banks

Transects

Upstream - T1 Center - T2

13. Distance from center of reach $(\mathrm{ft})$

14. Channel width $(\mathrm{ft})$

15. Bank width (ft)

16. Flood-plain width

$\frac{0}{15} \frac{1}{\text { no data }}$

Downstream - T3

75

15

no data $\frac{75}{14}$

Center Transect - T2 Latitude 305643 Longitude $930641 \pm 22 \mathrm{ft}$

17. Depth (feet)

18. Velocity $(\mathrm{ft} / \mathrm{s})$

19. Bed substrate

20. Embeddedness

\begin{tabular}{|c|c|c|c|c|}
\hline$\overline{\mathrm{LB}}$ & 3.75 & 7.5 & 11.25 & $\overline{R B}$ \\
\hline$\overline{0}$ & 3.8 & 3.5 & 2.6 & $\overline{0}$ \\
\hline 0 & 1.181 & 1.052 & 0.932 & 0 \\
\hline$\overline{\mathrm{SA}}$ & SA/GR & $\overline{\mathrm{GR}}$ & SA/GR & $\overline{\mathrm{SA}}$ \\
\hline 0 (none) & $2(75 \%)$ & $4(10 \%)$ & $2(75 \%)$ & 0 (none) \\
\hline
\end{tabular}

21. Canopy angle (degrees)

22. Aspect (azimuth - 360 degrees)

23. Habitat features

24. Bar/shelf/island

LB-left bank/RB-right bank

25. Bank angle (degrees)

26. Bank height ( $\mathrm{ft})$

27. Bank vegetation stability

28. Bank shape

29. Bank erosion

30. Bank substrate

31. Woody vegetation

$\frac{\text { Upstream - T1 }}{15}$
$\frac{\frac{90}{\text { WD/OV/UB }}}{\text { none }}$
$\frac{\text { LB }}{\frac{95}{7.5}} \frac{\text { RB }}{\frac{135}{6.5}}$
$\frac{3}{\frac{\mathrm{LN}}{\mathrm{MCB}}} \frac{\frac{\mathrm{LN}}{\text { none }}}{\mathrm{SA}}$
$\frac{\mathrm{pA} / \mathrm{hd} / \mathrm{sh}}{\mathrm{hd} / \mathrm{sh}}$

Center - T2

Downstream - T3

0

20

32. Photodocumentation

(center transect)

33. Diagrammatic map

none

refer to following page

140

WD, OV, UB

none

LB

$\frac{115}{3}-\frac{145}{6.5}$

3

LN

$\mathrm{MCB}$

SA

90

UB,WD,OV

LB - point bar

LB

145

6.5

$\frac{6.5}{3} \frac{6.5}{3}$

CV

none

SA

$\mathrm{p} / \mathrm{hd} / \mathrm{sh}$
RB

100

7.5

3

$\mathrm{LN}$

$\mathrm{MCB}$

SA/SI

hd/sh

34. Aquatic and riparian vegetation species - Refer to Appendicies B and C.

35. Comments

center transect $(\mathrm{RB})$ has abundant cypress trees and knees

secchi disk (light penetration) $=2.1 \mathrm{ft}$

\section{SECOND-LEVEL REACH CHARACTERIZATION}

Microhabitat characterization

Benthic invertabrate communities Refer to work in Appendix B by Dr. Vidrine.

Fish communities

Refer to previous work.

Figure 16. Stream characterization form for site 5 in the Limited Use Area, Vernon Ranger

District, Kisatchie National Forest, Louisiana--Continued. 


\section{SITE SKETCH}

Site 5. Drakes Creek 200 ft southeast of bridge on Forest Service Road 402.

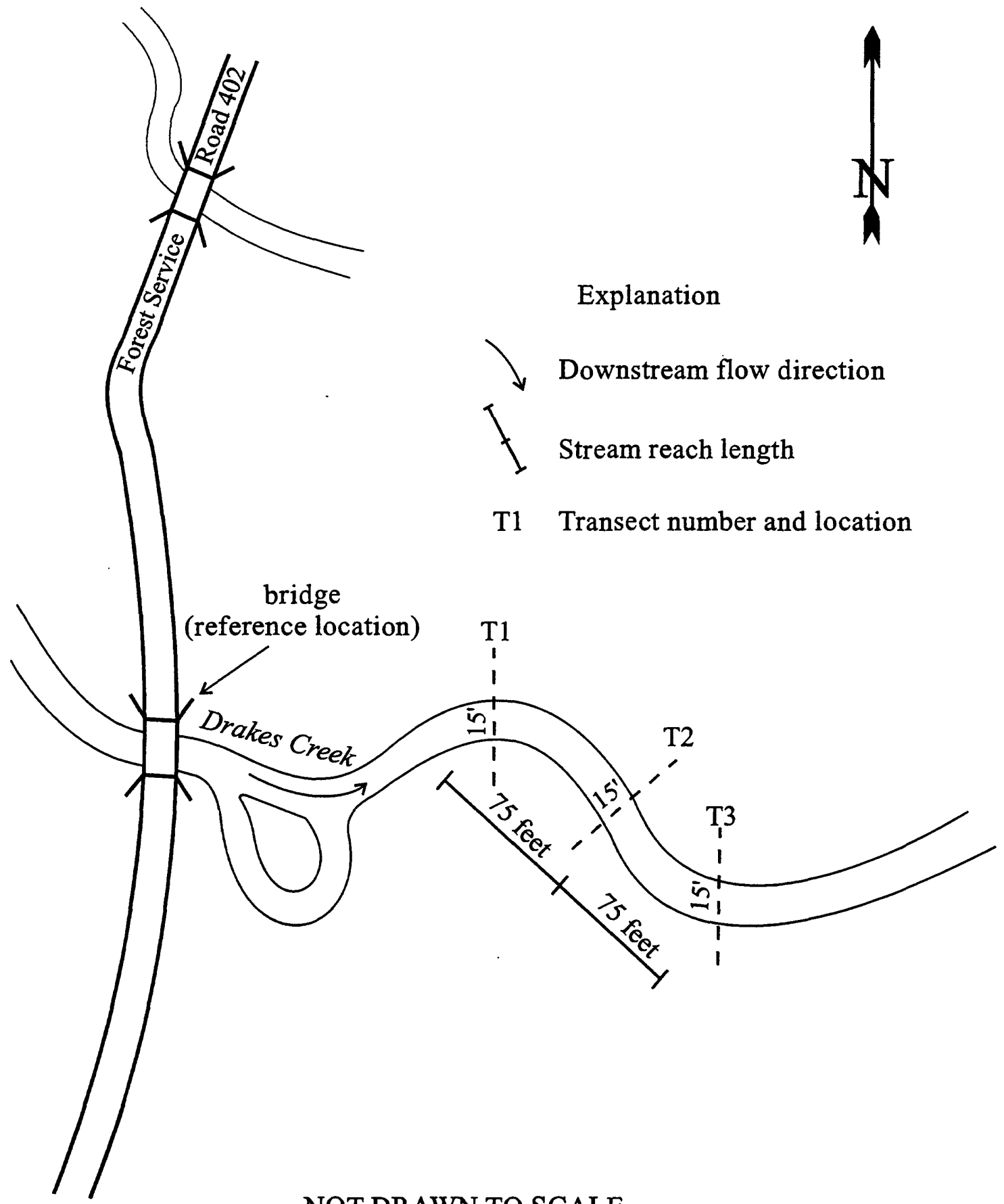

NOT DRAWN TO SCALE

Figure 16. Stream characterization form for site 5 in the Limited Use Area, Vernon Ranger District, Kisatchie National Forest, Louisiana--Continued. 


\section{STREAM CHARACTERIZATION FORM}

\section{BASIN CHARACTERIZATION}

1. Study unit

3. Station name

4. Station identification

5. Investigators

6. Reference location (bridge $\mathrm{H}-7$ )

7. Drainage area for Whiskey Chitto Creek north of the bridge on Lookout Road (map scale 1:50000)

8. Drainage density

10. Drainage Shape (1:50000)

12. Basin relief above site 6 (north)

14. Ecoregion $(1: 2,500,000)$

15. Physiographic province

16. Land use

17. Geologic type (map scale 1:500,000)

18. Soil type

19. Potential natural vegetation

20. Wetlands (bogs)

21. Mean annual precipitation
$\mathrm{ACAD}$

2. Date: November 1996 - February 1997

Whiskey Chitto Creek near Leesville $\sim 400 \mathrm{ft}$ south of bridge H-7 on Lookout Road. Downstream order number: $\underline{08013630}$ Site 6

C. R. Demas, R. B. Fendick, R. W. Tollett

Latitude: $310034 \quad$ Longitude: $930451 \pm 26 \mathrm{ft}$

$74.2 \mathrm{sq} \mathrm{km} \quad 28.7 \mathrm{sg} \mathrm{mi} \quad 18341$ acres

Not determined

3.5

$115 \mathrm{~m}-59 \mathrm{~m}=56 \mathrm{~m}$

9. Drainage Texture Not determined

11. Stream length $20.6 \mathrm{~km}$

13. Storage Not determined

South Central Plains

West Gulf Coastal Plain

FO - Deciduous forest land (De) and Evergreens (Ev)

Qth-High terraces The Pleistocene terrace deposits unconformably overlay the Pliocene-Pleistocene deposits of the the Blounts Creek Member of the Fleming Formation. High terrace deposits are defined as tan to orange clay, silt, and sand with large amounts of basal gravel.

Mfb-Blounts Creek Member The Blounts Creek Member of the Fleming Formation overlies the Castor Creek Member. Blounts Creek Member is described as a gray to green silty clays, siltstones, and silts with abundant sand beds wih some lignite and lenses of black chert gravel.

moist ultisols (udults)

oak/hickory/pine - woodland and forest w/some cropland and pasture Refer to figure 2 for bog locations, and Appendix $\mathrm{C}$ for descriptions. Over the past 5 years, mean annual precipitation was $58.3 \mathrm{in} / \mathrm{yr}$.

\section{SEGMENT CHARACTERIZATION}

1. Study unit

3. Station name

4. Station identification

5. Investigators

6. Reference location (bridge $\mathrm{H}-7$ )

7. State

9. Township

11. Section

12. Quadrangle

13. Segment code

14. Segment length (1:50000)

15. Elevation of reference location

16. Sideslope gradient

17. Segment gradient

18. Channel sinuosity

19. Stream order

21. Water management feature
$\mathrm{ACAD}$

2. Date: November 1996 - February 1997

Whiskey Chitto Creek near Leesville $-400 \mathrm{ft}$ south of bridge H-7 on Lookout Road. Downstream order number: $\underline{8013630}$ Site 6

C. R. Demas, R. B. Fendick, R. W. Tollett

Latitude: $310034 \quad$ Longitude: $930451 \pm 26 \mathrm{ft}$

Louisiana 8. Parish Vernon

T.1S 10. Range R.7 W

SW $1 / 4$, NW $1 / 4$, section 3

BIRDS CREEK QUADRANGLE - 7.5 Minute Series (Topographic)

Not determined

Stream length above site 6 is $20.6 \mathrm{~km}$.

$190 \mathrm{ft}$ or $59 \mathrm{~m}$ (land surface elevation at bridge $\mathrm{H}-7$ )

Not determined

0.0027

$\frac{1.5}{2}$

20. Downstream link 3

Figure 17. Stream characterization form for site 6 in the Limited Use Area, Vernon Ranger District, Kisatchie National Forest, Louisiana. 


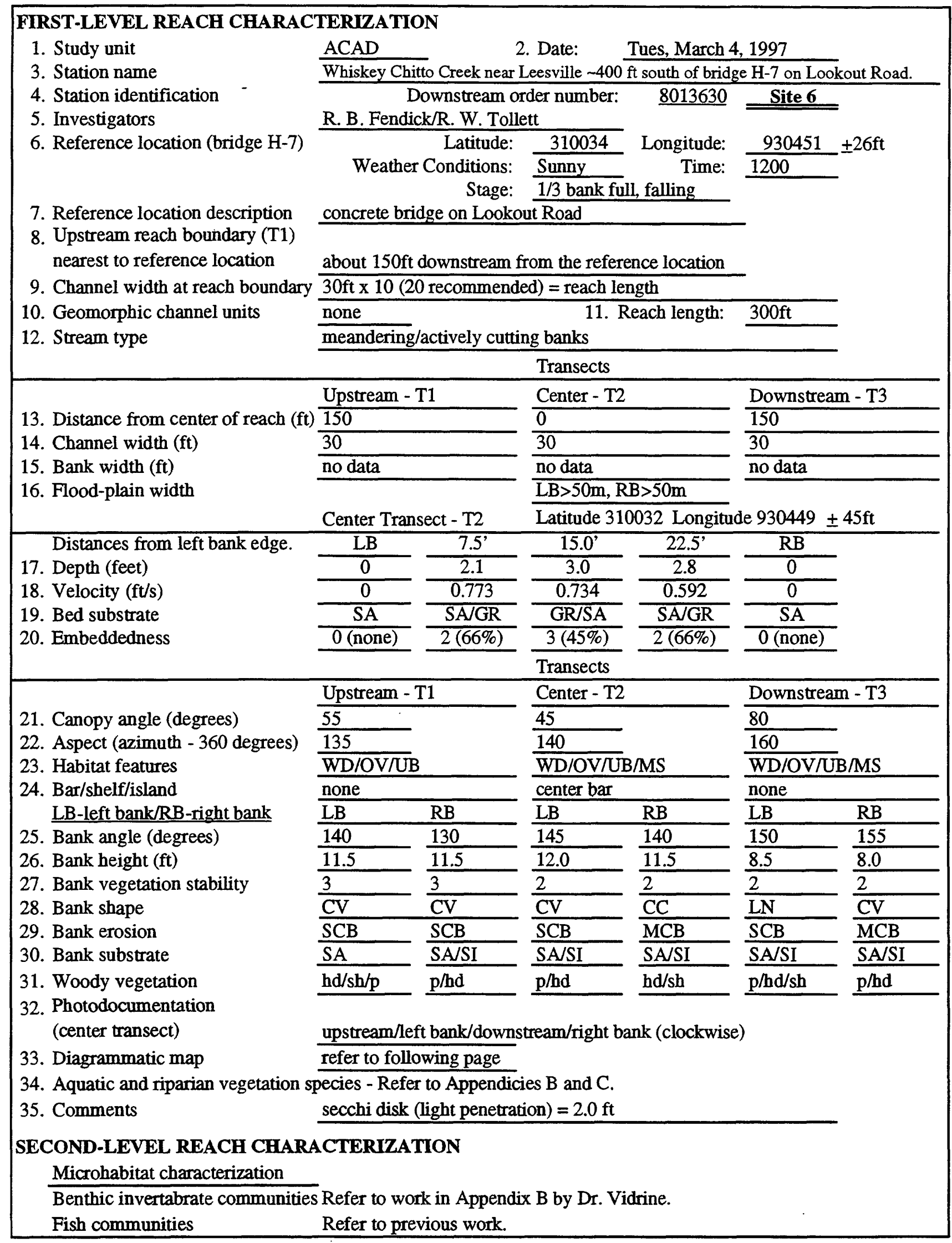

Figure 17. Stream characterization form for site 6 in the Limited Use Area, Vernon Ranger

District, Kisatchie National Forest, Louisiana--Continued. 


\section{SITE SKETCH}

Site 6. Whiskey Chitto Creek near Leesville $\sim 400 \mathrm{ft}$ south of bridge H-7 on Lookout Road.

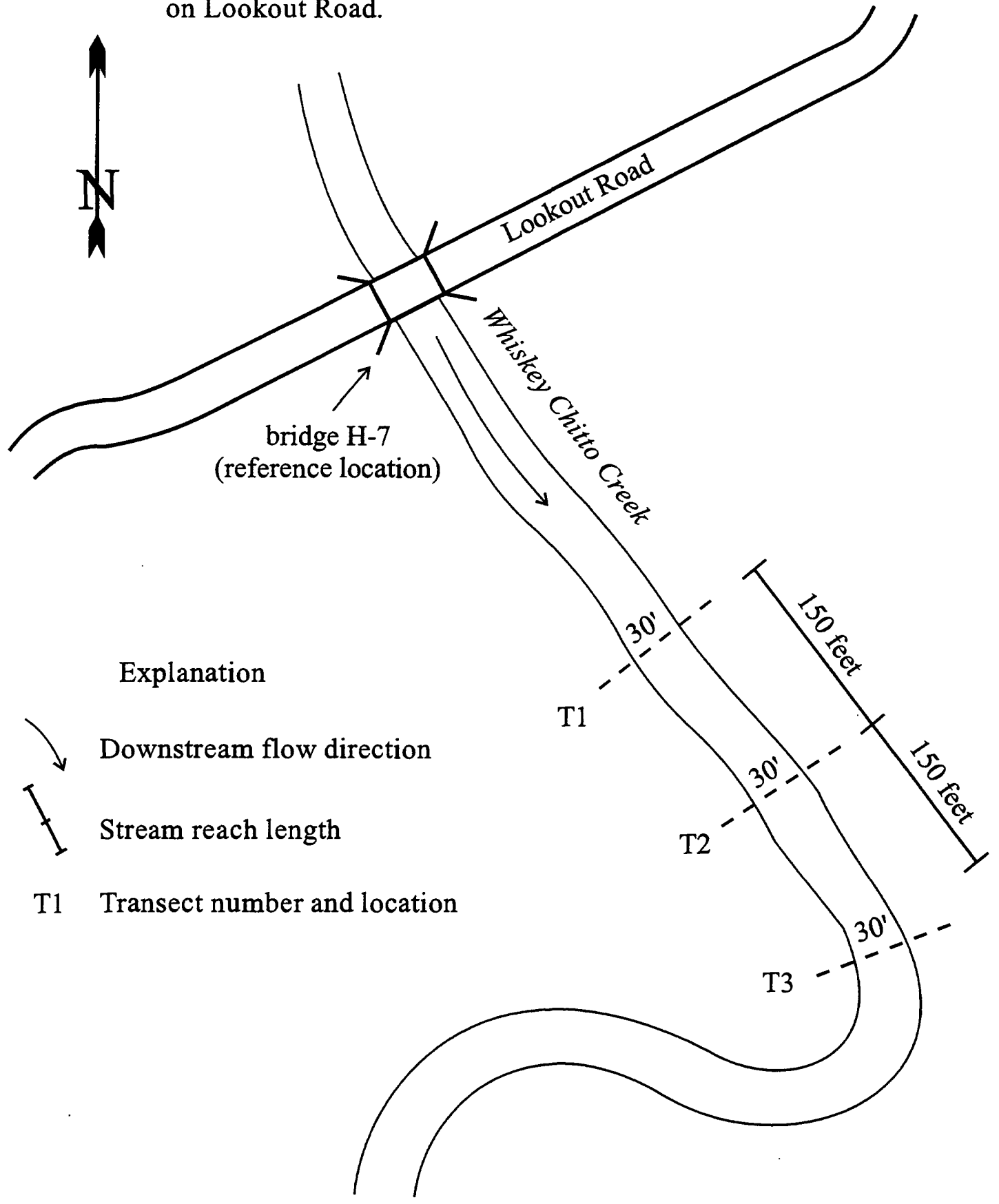

NOT DRAWN TO SCALE

Figure 17. Stream characterization form for site 6 in the Limited Use Area, Vernon Ranger District, Kisatchie National Forest, Louisiana--Continued. 


\section{STREAM CHARACTERIZATION FORM}

BASIN CHARACTERIZATION
1. Study unit
ACAD
2. Date: November 1996 - February 1997
3. Station name
4. Station identification
Whiskey Chitto Creek $-200 \mathrm{ft}$ north of bridge on Ray Gill Road east of Leesville. Downstream order number: $\underline{08013660}$ Site 7
5. Investigators
6. Reference location (bridge)
C. R. Demas, R. B. Fendick, R. W. Tollett
7. Drainage area for Whiskey Chitto Latitude: 305847
Longitude: $930320 \pm 25 \mathrm{ft}$ Creek north of the bridge on Ray Gill Road (map scale 1:50000)
8. Drainage density
10. Drainage Shape (1:50000)
12. Basin relief above site 7 (north)
14. Ecoregion $(1: 2,500,000)$
15. Physiographic province
16. Land use
17. Geologic type
(map scale 1:500,000)

\begin{tabular}{|c|c|c|c|}
\hline $145.3 \mathrm{sq} \mathrm{km}$ & $56.1 \mathrm{sg} \mathrm{mi}$ & 35901 acres & \\
\hline Not determined & & 9. Drainage Texture & Not determined \\
\hline 2.7 & & 11. Stream length & $25.6 \mathrm{~km}$ \\
\hline
\end{tabular}
$115 \mathrm{~m}-56 \mathrm{~m}=59 \mathrm{~m}$
13. Storage Not determined
South Central Plains
West Gulf Coastal Plain
FO - Deciduous forest land (De) and Evergreens (Ev)
Qth-High terraces The Pleistocene terrace deposits unconformably overlay the Pliocene-Pleistocene deposits of the the Blounts Creek Member of the Fleming Formation. High terrace deposits are defined as tan to orange clay, silt, and sand with large amounts of basal gravel.
Mfb-Blounts Creek Member The Blounts Creek Member of the Fleming Formation overlies the Castor Creek Member. Blounts Creek Member is described as a gray to green silty clays, siltstones, and silts with abundant sand beds wih some lignite and lenses of black chert gravel.
18. Soil type
19. Potential natural vegetation moist ultisols (udults)
oak/hickory/pine - woodland and forest w/some cropland and pasture
20. Wetlands (bogs)
21. Mean annual precipitation
Refer to figure 2 for bog locations, and Appendix $\mathrm{C}$ for descriptions.
Over the past 5 years, mean annual precipitation was 58.3 in/yr.

\section{SEGMENT CHARACTERIZATION}

1. Study unit

3. Station name

4. Station identification

5. Investigators

6. Reference location (bridge)

7. State

9. Township

11. Section

12. Quadrangle

13. Segment code

14. Segment length (1:50000)

15. Elevation of reference location

16. Sideslope gradient

17. Segment gradient

18. Channel sinuosity

19. Stream order

21. Water management feature
ACAD

2. Date: November 1996 - February 1997

Whiskey Chitto Creek $200 \mathrm{ft}$ north of bridge on Ray Gill Road east of Leesville.

$$
\text { Downstream order number: } \quad \underline{8013660} \quad \text { Site } 7
$$

C. R. Demas, R. B. Fendick, R. W. Tollett

Latitude: $305847 \quad$ Longitude: $930320 \pm 25 \mathrm{ft}$

Louisiana

8. Parish Vernon

T. $1 \mathrm{~S}$

10. Range R. $7 \mathrm{~W}$

SW 1/4, NE 1/4, section 14

SUGRUE QUADRANGLE - 7.5 Minute Series (Topographic)

Not determined

Stream length above site 7 is $-25.6 \mathrm{~km}$.

$179 \mathrm{ft}$ or $56 \mathrm{~m}$ (land surface elevation at bridge)

Not determined

0.0023

1.5

3

None
20. Downstream link 4

Figure 18. Stream characterization form for site 7 in the Limited Use Area, Vernon Ranger District, Kisatchie National Forest, Louisiana. 


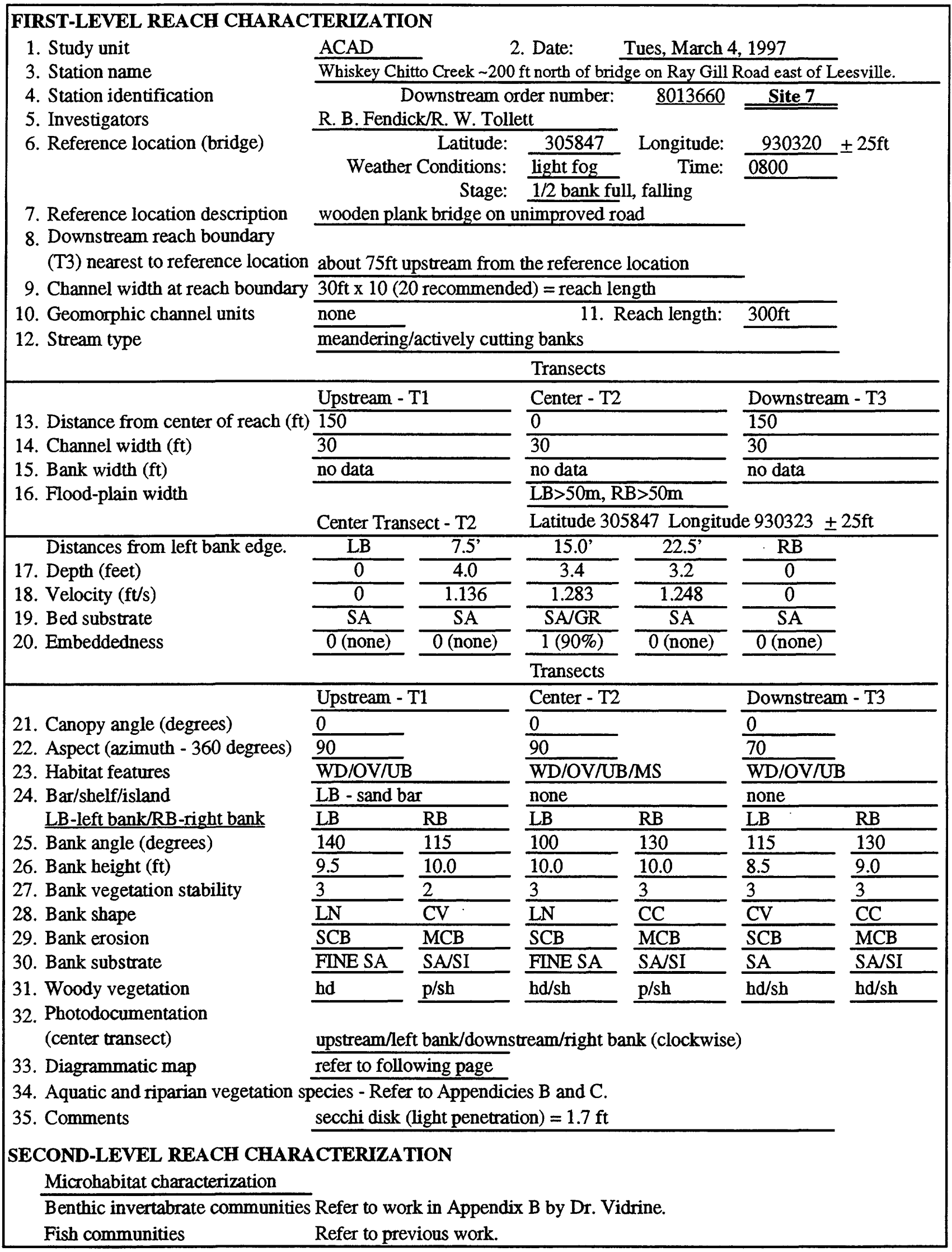

Figure 18. Stream characterization form for site 7 in the Limited Use Area, Vernon Ranger

District, Kisatchie National Forest, Louisiana--Continued. 


\section{SITE SKETCH}

Site 7. Whiskey Chitto Creek $200 \mathrm{ft}$ northwest of bridge on Ray Gill Road east of Leesville.
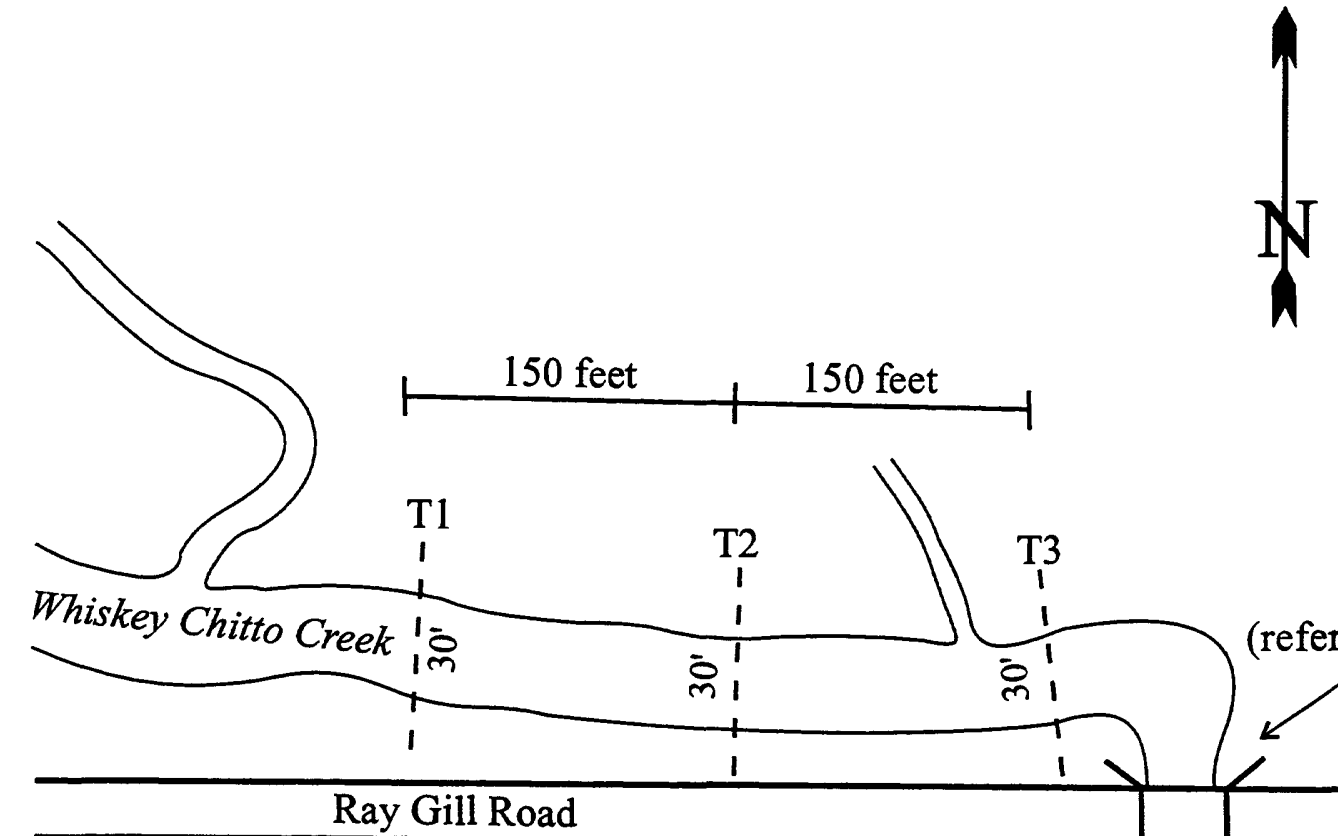

Explanation

$\searrow$ Downstream flow direction

$£$ Stream reach length

T1 Transect number and location

NOT DRAWN TO SCALE

Figure 18. Stream characterization form for site 7 in the Limited Use Area, Vernon Ranger District, Kisatchie National Forest, Louisiana--Continued. 


\section{STREAM CHARACTERIZATION FORM}

\section{BASIN CHARACTERIZATION}

1. Study unit

3. Station name

4. Station identification

5. Investigators

6. Reference location (bridge)

7. Drainage area for Whiskey Chitto Creek north of the old railroad bridge (map scale 1:50000)

8. Drainage density

10. Drainage Shape (1:50000)

12. Basin relief above site 8 (north)

14. Ecoregion $(1: 2,500,000)$

15. Physiographic province

16. Land use

17. Geologic type (map scale 1:500,000)

18. Soil type

19. Potential natural vegetation

20. Wetlands (bogs)

21. Mean annual precipitation
$\mathrm{ACAD}$

2. Date: November 1996 - February 1997

Whiskey Chitto Creek $-200 \mathrm{ft}$ north of old Athison Topeka and Santa Fe railroad bridge. Downstream order number: none Site 8

C. R. Demas, R. B. Fendick, R. W. Tollett

Latitude: $305723 \quad$ Longitude: $\underline{930322} \pm 40 \mathrm{ft}$

$150.8 \mathrm{sq} \mathrm{km} \quad 58.12 \mathrm{sq} \mathrm{mi} \quad 37253$ acres

Not determined

3.3

$115 \mathrm{~m}-51 \mathrm{~m}=62 \mathrm{~m}$

9. Drainage Texture Not determined

11. Stream length

13. Storage Not determined

South Central Plains

West Gulf Coastal Plain

FO - Deciduous forest land (De) and Evergreens (Ev)

Qth-High terraces The Pleistocene terrace deposits unconformably

overlay the Pliocene-Pleistocene deposits of the the Blounts Creek Member of the Fleming Formation. High terrace deposits are defined as tan to orange clay, silt, and sand with large amounts of basal gravel.

Mfb-Blounts Creek Member The Blounts Creek Member of the Fleming Formation overlies the Castor Creek Member. Blounts Creek Member is described as a gray to green silty clays, siltstones, and silts with abundant sand beds wih some lignite and lenses of black chert gravel.

moist ultisols (udults)

oak/hickory/pine - woodland and forest w/some cropland and pasture

Refer to figure 2 for bog locations, and Appendix $\mathrm{C}$ for descriptions.

Over the past 5 years, mean annual precipitation was 58.3 in/yr.

\section{SEGMENT CHARACTERIZATION}

1. Study unit

3. Station name

4. Station identification

5. Investigators

6. Reference location (bridge)

7. State

9. Township

11. Section

12. Quadrangle

13. Segment code

14. Segment length (1:50000)

15. Elevation of reference location

16. Sideslope gradient

17. Segment gradient

18. Channel sinuosity

19. Stream order

21. Water management feature
$\mathrm{ACAD}$

2. Date: November 1996 - February 1997

Whiskey Chitto Creek $-200 \mathrm{ft}$ north of old Athison Topeka and Santa Fe railroad bridge. Downstream order number: none Site 8

C. R. Demas, R. B. Fendick, R. W. Tollett

$\frac{\text { Latitude: } 305723}{8} \quad$ Longitude: $930322 \pm 40 \mathrm{ft}$

Louisiana

T. $1 \mathrm{~S}$

8. Parish Vernon

SW $1 / 4$, SE $1 / 4$, section 23

SUGRUE QUADRANGLE - 7.5 Minute Series (Topographic)

Not determined

Stream length above site 8 is $\sim 26.3 \mathrm{~km}$.

$165 \mathrm{ft}$ or $51 \mathrm{~m}$ (land surface elevation at bridge)

Not determined

0.0024

$\frac{0.0024}{1.3}$

20. Downstream link 4

Figure 19. Stream characterization form for site 8 in the Limited Use Area, Vernon Ranger District, Kisatchie National Forest, Louisiana. 


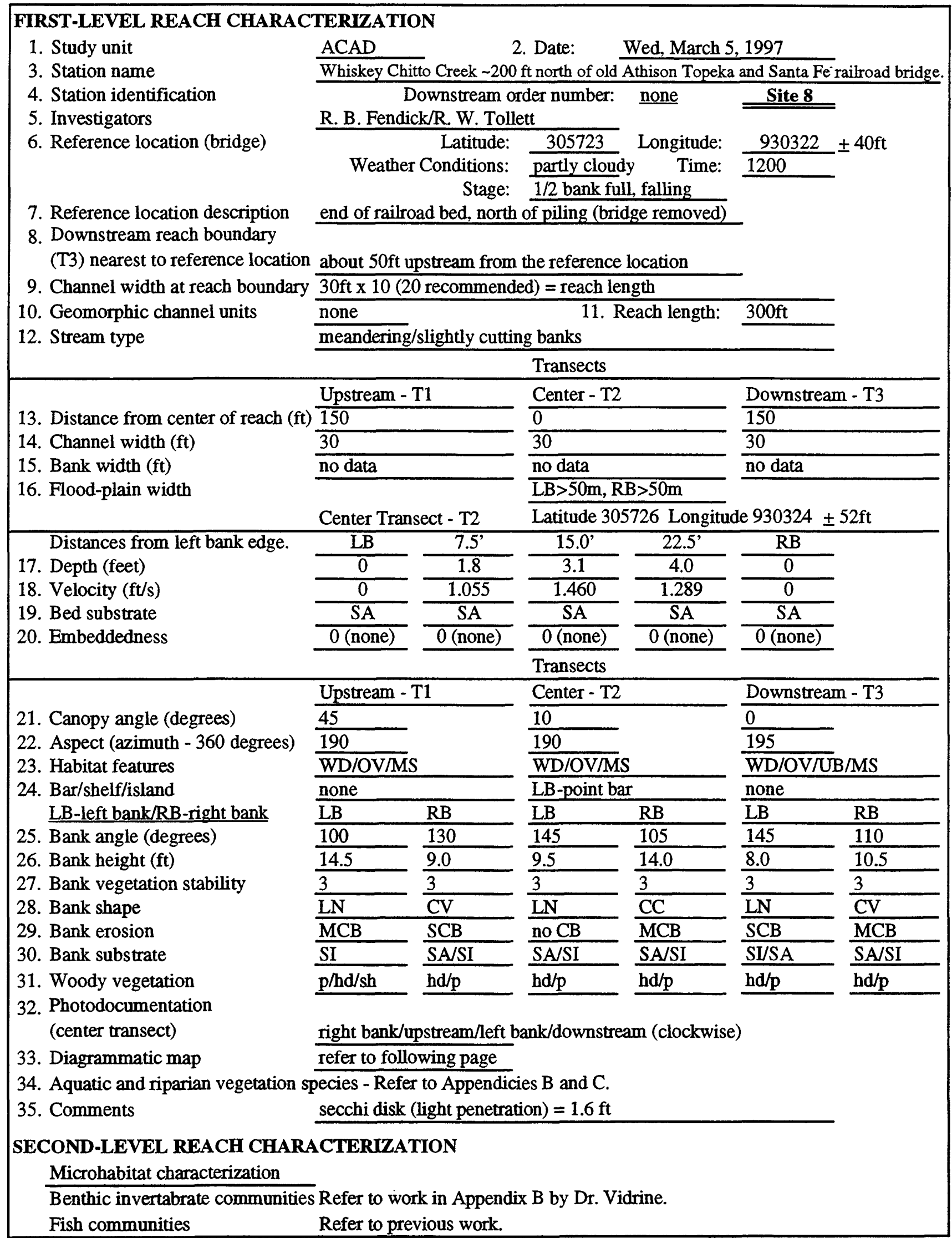

Figure 19. Stream characterization form for site 8 in the Limited Use Area, Vernon Ranger District, Kisatchie National Forest, Louisiana--Continued. 


\section{SITE SKETCH}

Site 8. Whiskey Chitto Creek $\sim 200 \mathrm{ft}$ north of old Athison Topeka and Santa Fe railroad bridge.
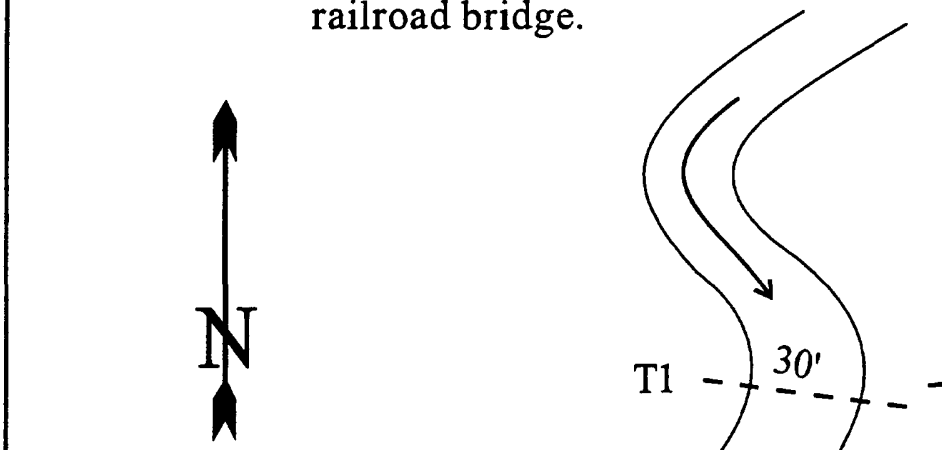
BASIN CHARACTERIZATION

1. Study unit

3. Station name

4. Station identification

5. Investigators

6. Reference location (bridge $\mathrm{H}-8$ )

7. Drainage area for Birds Creek north of the bridge on Lookout Road (map scale 1:50000)

8. Drainage density

10. Drainage Shape (1:50000)

12. Basin relief above site 9

14. Ecoregion $(1: 2,500,000)$

15. Physiographic province

16. Land use

17. Geologic type

(map scale 1:500,000)

18. Soil type

19. Potential natural vegetation

20. Wetlands (bogs)

21. Mean annual precipitation
$\mathrm{ACAD}$

2. Date: November 1996 - February 1997

Birds Creek near Cravens $200 \mathrm{ft}$ south of bridge H-8 on Lookout Road Downstream order number: $\underline{08013650}$ Site 9

C. R. Demas, R. B. Fendick, R. W. Tollett

Latitude: $310116 \quad$ Longitude: $930313 \pm 32 \mathrm{ft}$

$56.5 \mathrm{sq} \mathrm{km} \quad 21.8 \mathrm{sq} \mathrm{mi} \quad 13955$ acres

Not determined

4.3

9. Drainage Texture

11. Stream length

Not determined

$137 \mathrm{~m}-60 \mathrm{~m}=77 \mathrm{~m}$

13. Storage

$18.4 \mathrm{~km}$

South Central Plains

West Gulf Coastal Plain

FO - Deciduous forest land (De) and Evergreens (Ev)

Qth-High terraces The Pleistocene terrace deposits unconformably overlay the Pliocene-Pleistocene deposits of the the Blounts Creek Member of the Fleming Formation. High terrace deposits are defined as tan to orange clay, silt, and sand with large amounts of basal gravel.

Mfb-Blounts Creek Member The Blounts Creek Member of the Fleming Formation overlies the Castor Creek Member. Blounts Creek Member is described as a gray to green silty clays, siltstones, and silts with abundant sand beds wih some lignite and lenses of black chert gravel. moist ultisols (udults) oak/hickory/pine - woodland and forest w/some cropland and pasture Refer to figure 2 for bog locations, and Appendix $\mathrm{C}$ for descriptions. Over the past 5 years, mean annual precipitation was 58.3 in/yr.

\section{SEGMENT CHARACTERIZATION}

1. Study unit

3. Station name

4. Station identification

5. Investigators

6. Reference location (bridge $\mathrm{H}-8$ )

7. State

9. Township

11. Section

12. Quadrangle

13. Segment code

14. Segment length (1:50000)

15. Elevation of reference location

16. Sideslope gradient

17. Segment gradient

18. Channel sinuosity

19. Stream order

21. Water management feature
$\mathrm{ACAD}$

2. Date: November 1996 - February 1997

Birds Creek near Cravens $\sim 200 \mathrm{ft}$ south of bridge H-8 on Lookout Road. Downstream order number: $\underline{08013650 \quad \text { Site } 9}$

C. R. Demas, R. B. Fendick, R. W. Tollett

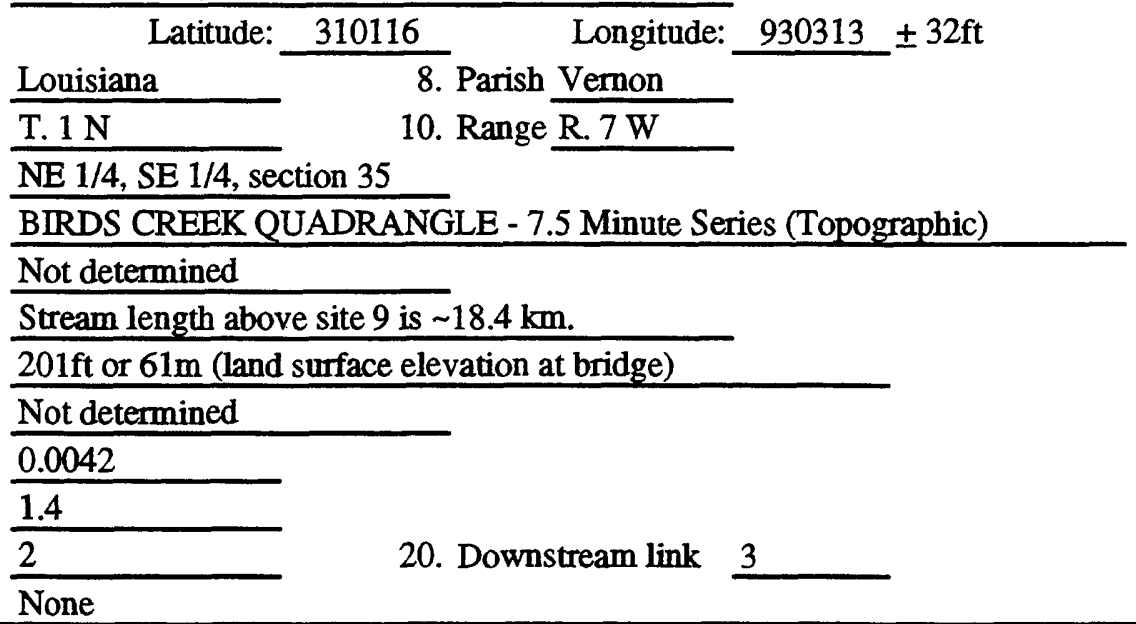

Figure 20. Stream characterization form for site 9 in the Limited Use Area, Vernon Ranger District, Kisatchie National Forest, Louisiana. 


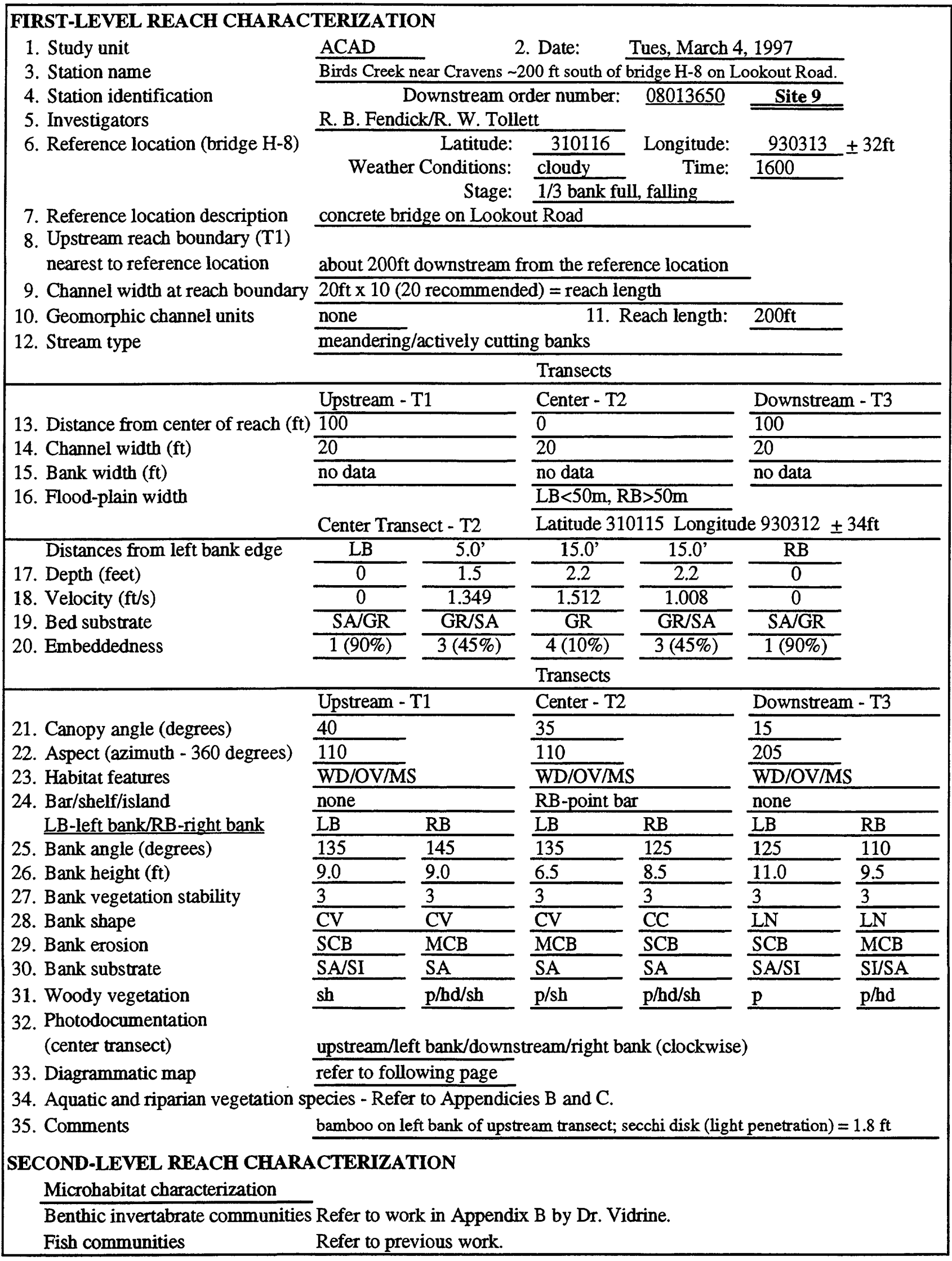

Figure 20. Stream characterization form for site 9 in the Limited Use Area, Vernon Ranger District, Kisatchie National Forest, Louisiana--Continued. 


\section{SITE SKETCH}

Site 9. Birds Creek near Cravens $\sim 200 \mathrm{ft}$ south of bridge H-8 on Lookout Road.

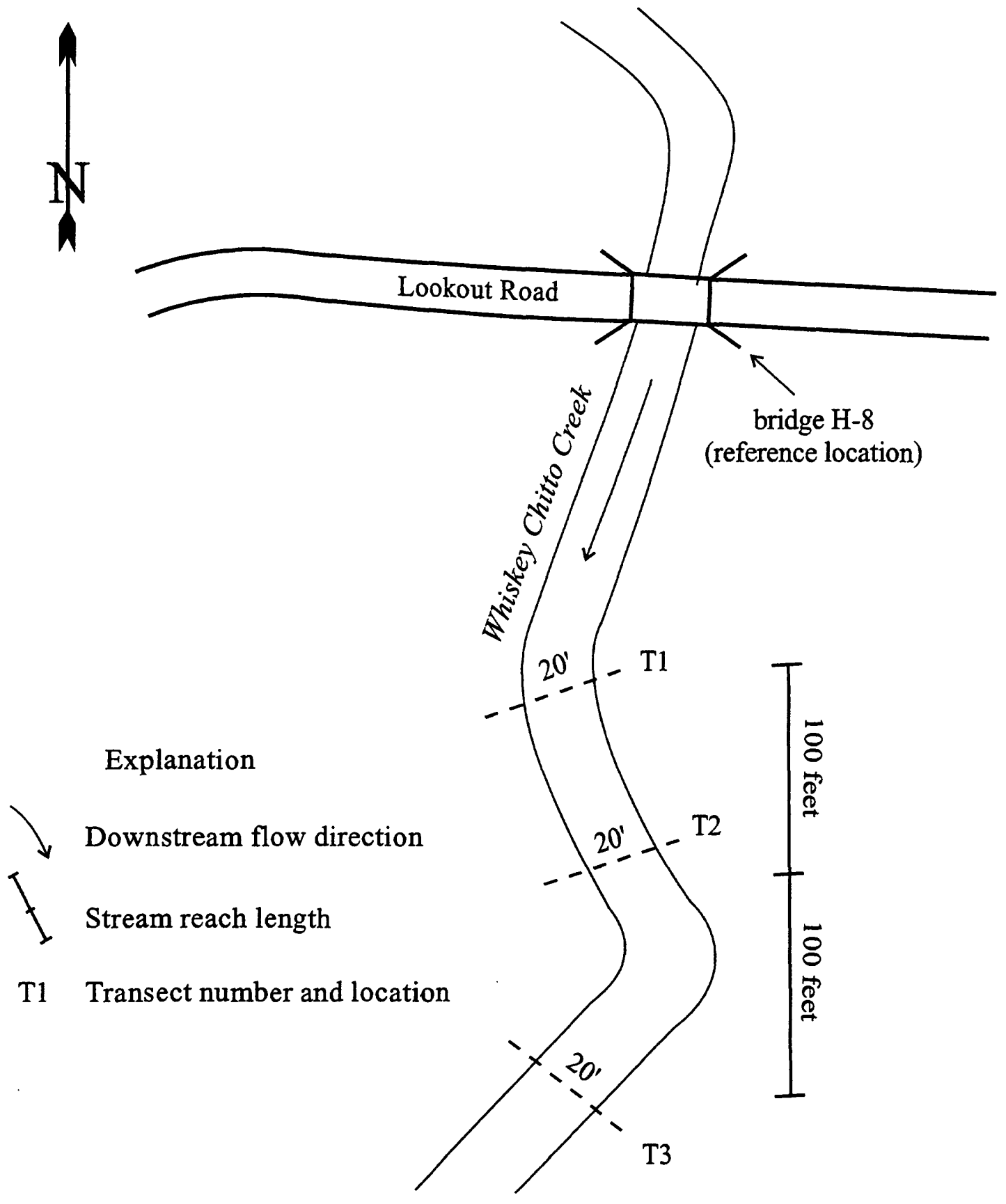

NOT DRAWN TO SCALE

Figure 20. Stream characterization form for site 9 in the Limited Use Area, Vernon Ranger District, Kisatchie National Forest, Louisiana--Continued. 


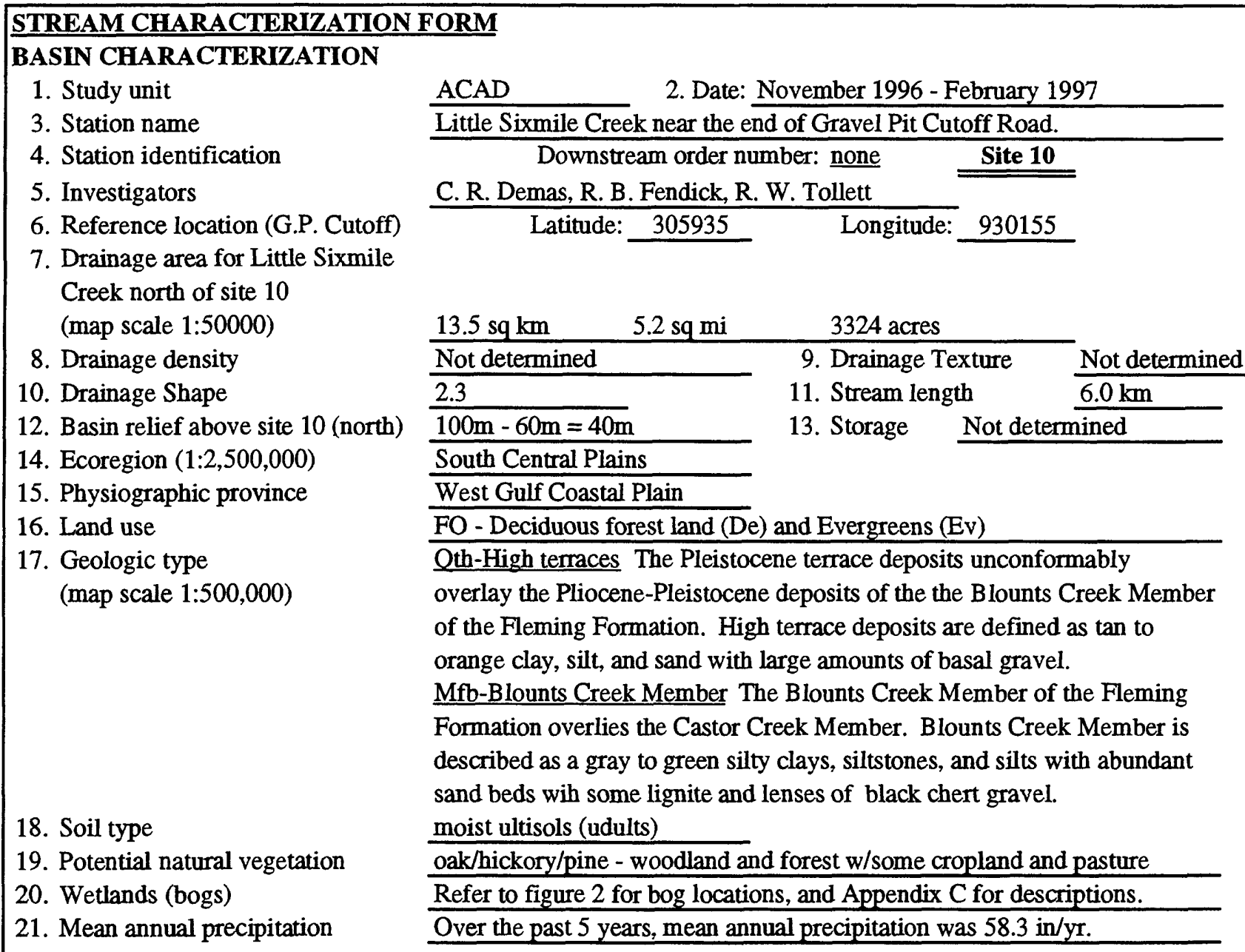

\section{SEGMENT CHARACTERIZATION}

1. Study unit

3. Station name

4. Station identification

5. Investigators

6. Reference location (G.P. Cutoff)

7. State

9. Township

11. Section

12. Quadrangle

13. Segment code

14. Segment length (1:50000)

15. Elevation of reference location

16. Sideslope gradient

17. Segment gradient

18. Channel sinuosity (1:50000)

19. Stream order

21. Water management feature
$\mathrm{ACAD}$

2. Date: November 1996 - February 1997

Little Sixmile Creek near the end of Gravel Pit Cutoff Road.

Downstream order number: none

C. R. Demas, R. B. Fendick, R. W. Tollett

Latitude: $305935 \quad$ Longitude: 930155

Louisiana

8. Parish Vernon

T. $1 \mathrm{~S}$

10. Range R. $6 \mathrm{~W}$

SW $1 / 4$, NW1/4, section 7

SUGRUE QUADRANGLE - 7.5 Minute Series (Topographic)

Not determined

Stream length above site 10 is $6.0 \mathrm{~km}$.

$195 \mathrm{ft}$ or $59 \mathrm{~m}$ (land surface elevation of land near site 10)

Not determined

0.0066

2.0

1

None

20. Downstream link 2

Figure 21. Stream characterization form for site 10 in the Limited Use Area, Vernon Ranger

District, Kisatchie National Forest, Louisiana. 


\section{FIRST-LEVEL REACH CHARACTERIZATION}

1. Study unit

3. Station name

4. Station identification

5. Investigators

6. Reference location

Reference location description

8. Upstream reach boundary (T1)

nearest to reference location

9. Channel width at reach boundary

10. Geomorphic channel units

12. Stream type
$\mathrm{ACAD}$

2. Date:

Wed, March 5, 1997

Little Sixmile Creek near the end of Gravel Pit Cutoff Road.

Downstream order number: none

Site 10

Rob Fendick/Roland W. Tollett

$$
\text { Latitude: } \frac{305935}{\text { Larty }} \text { Longitude: } \quad 930155 \pm 30
$$

Weather Conditions: Partly sunny Time: 1300

Stage: $1 / 2$ bank full/falling

intersection of Gravel Pit Cutoff Road and a pipeline

about $300 \mathrm{ft}$ east of the reference location

$10 \mathrm{ft} \times 10$ (20 recommended $)=$ reach length

none 11. Reach length: $100 \mathrm{ft}$
meandering/actively cutting banks

Transects

Upstream - T1 Center - T2

13. Distance from center of reach $(\mathrm{ft})$

14. Channel width (ft)

15. Bank width (ft)

16. Flood-plain width $\frac{0}{10}$

LB $<50 \mathrm{~m}, \mathrm{RB} \sim 50 \mathrm{~m}$
Downstream - T3

Distances from left bank edge.

17. Depth (feet)

18. Velocity $(\mathrm{ft} / \mathrm{s})$

19. Bed substrate

20. Embeddedness

$\frac{\frac{50}{12}}{\text { no data }}$

Center Transect - T2 Latitude 305933 Longitude $930149 \pm 34 \mathrm{ft}$

21. Canopy angle (degrees)

22. Aspect (azimuth - 360 degrees)

23. Habitat features

24. Bar/shelf/island

LB-left bank/RB-right bank

25. Bank angle (degrees)

26. Bank height ( $\mathrm{ft}$ )

27. Bank vegetation stability

28. Bank shape

29. Bank erosion

30. Bank substrate

31. Woody vegetation

32. Photodocumentation

(center transect)

33. Diagrammatic map

$\frac{\frac{\mathrm{LB}}{0} \frac{2.5}{\frac{1.0}{0}} \frac{1.118}{\frac{\mathrm{SA} / \mathrm{GR}}{1(90 \%)}} \frac{\mathrm{GR} / \mathrm{SA}}{2(75 \%)}}{1}$

\begin{tabular}{c}
$\frac{5.0^{\prime}}{0.9}$ \\
$\frac{1.280}{\mathrm{GR}}$ \\
\hline$\frac{3(45 \%)}{\text { Transects }}$
\end{tabular}

\begin{tabular}{ccc}
$\frac{7.5}{0.8}$ & $\frac{\mathrm{RB}}{0}$ \\
$\frac{0.885}{\mathrm{GR} / \mathrm{SA}}$ & $\frac{0}{\mathrm{SA} / \mathrm{GR}}$ \\
\hline $2(75 \%)$ & $\frac{1(90 \%)}{1(90}$
\end{tabular}

Upstream - T

20

180

$\overline{\mathrm{WD} / \mathrm{OV} / \mathrm{UB}}$

gravel bar - RB

LB

145

3.0

3

3

SCB

SA/SI

$\mathrm{hd} / \mathrm{sh}$

RB

155

2.5

$\frac{2.5}{3}$

$\frac{3}{\mathrm{LN}}$

none

SA/GR

$\mathrm{p} / \mathrm{hd} / \mathrm{sh}$

upstream/left bank (clockwise) - end of roll

refer to following page

34. Aquatic and riparian vegetation species - Refer to Appendicies B and C.

35. Comments

secchi disk (light penetration) $=$ to depth

\section{SECOND-LEVEL REACH CHARACTERIZATION}

Microhabitat characterization

Benthic invertabrate communities Refer to work in Appendix C by Dr. Vidrine.

Fish communities

Refer to previous work.

Figure 21. Stream characterization form for site 10 in the Limited Use Area, Vernon Ranger

District, Kisatchie National Forest, Louisiana--Continued. 


\section{SITE SKETCH}

Site 10. Little Sixmile Creek near the end of Gravel Pit Cutoff Road.
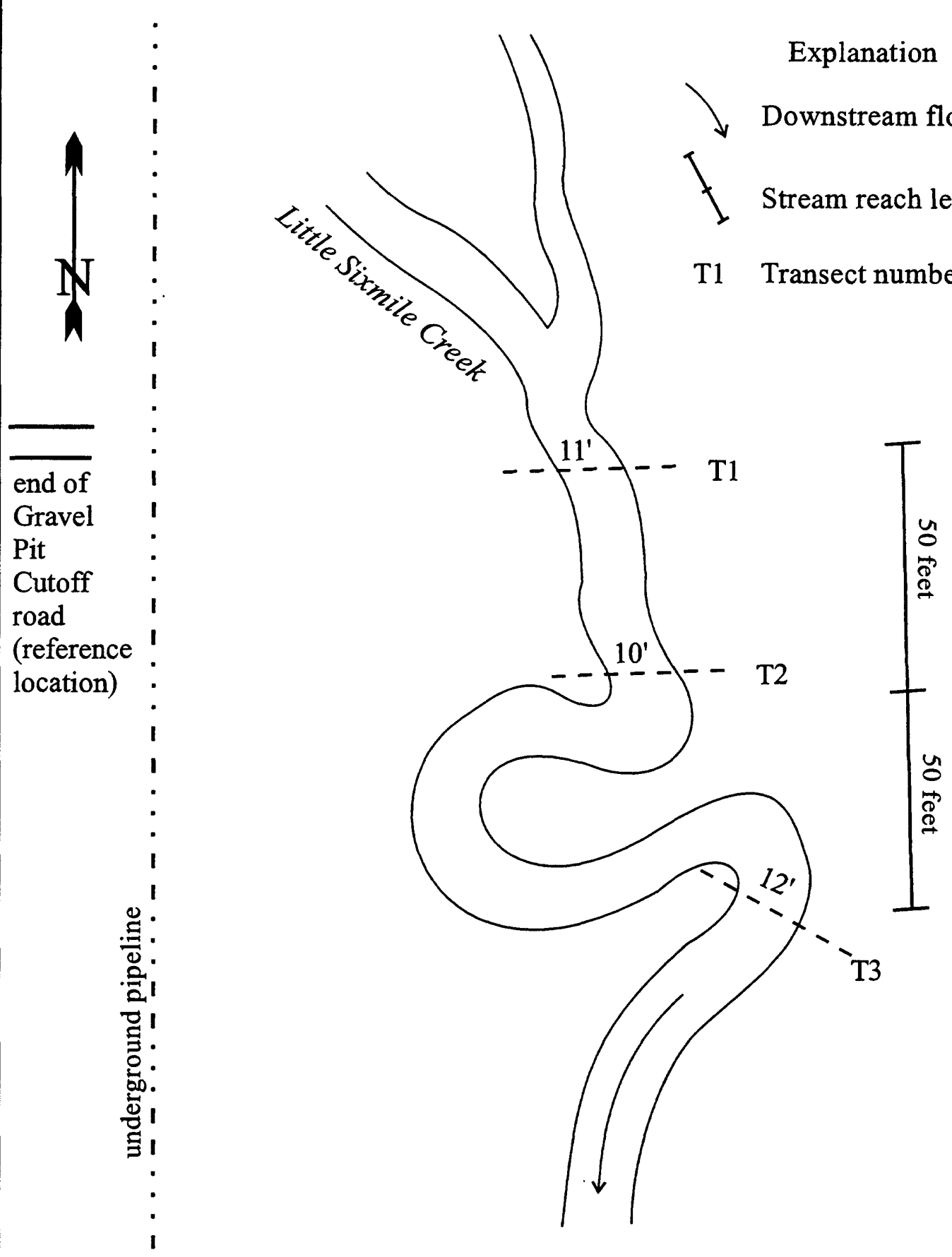

NOT DRAWN TO SCALE

Figure 21. Stream characterization form for site 10 in the Limited Use Area, Vernon Ranger District, Kisatchie National Forest, Louisiana--Continued. 


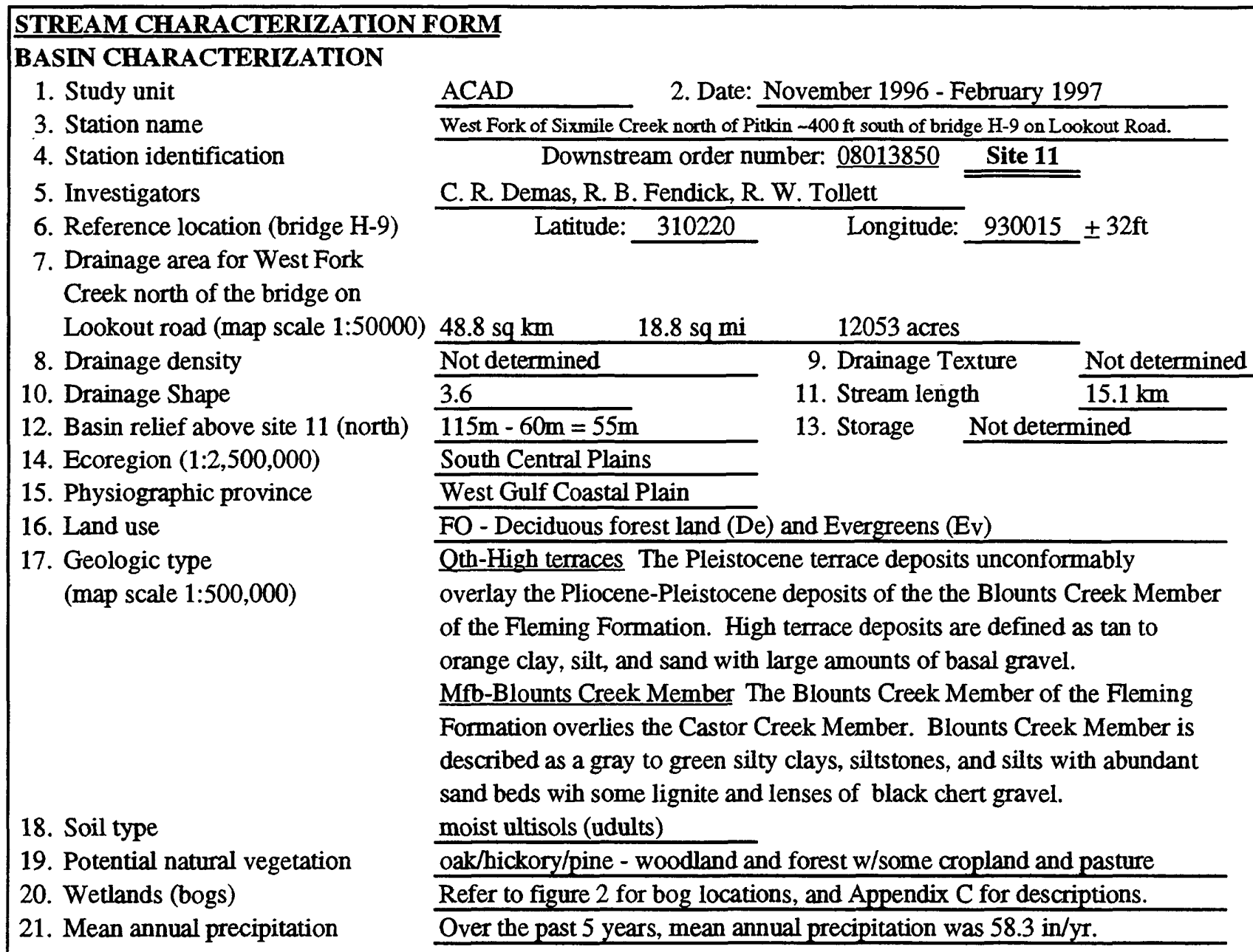

\section{SEGMENT CHARACTERIZATION}

1. Study unit

3. Station name

4. Station identification

5. Investigators

6. Reference location (bridge H-9)

7. State

9. Township

11. Section

12. Quadrangle

13. Segment code

14. Segment length (1:50000)

15. Elevation of reference location

16. Sideslope gradient

17. Segment gradient

18. Channel sinuosity (1:50000)

19. Stream order

21. Water management feature
$\mathrm{ACAD}$

2. Date: November 1996 - February 1997

West Fork of Sixmile Creek north of Pitkin $-400 \mathrm{ft}$ south of bridge H-9 on Lookout Road. Downstream order number: $\underline{08013850}$ Site 11

C. R. Demas, R. B. Fendick, R. W. Tollett

Latitude: $310220 \quad$ Longitude: $930015 \pm 32 \mathrm{ft}$

Louisiana 8. Parish Vernon

T.1 N 10 . Range R.6 W

SE $1 / 4$, NE1/4, section 29

BIRDS CREEK QUADRANGLE - 7.5 Minute Series (Topographic)

Not determined

Stream length above site 11 is $15.1 \mathrm{~km}$.

$200 \mathrm{ft}$ or $60 \mathrm{~m}$ (land surface elevation at bridge $\mathrm{H}-9$ )

Not determined

0.0036

1.5

2

None
20. Downstream link 3

Figure 22. Stream characterization form for site 11 in the Limited Use Area, Vernon Ranger

District, Kisatchie National Forest, Louisiana. 


\section{FIRST-LEVEL REACH CHARACTERIZATION}

1. Study unit

3. Station name

4. Station identification

5. Investigators

6. Reference location (bridge $\mathrm{H}-9$ )

7. Reference location description

8. Upstream reach boundary (T1) nearest to reference location

9. Channel width at reach boundary

10. Geomorphic channel units

12. Stream type
$\mathrm{ACAD}$

2. Date:

Tues, March 4, 1997

West Fork of Sixmile Creek north of Pitkin $-400 \mathrm{ft}$ south of bridge H-9 on Lookout Road.

Downstream order number: $\underline{08013850} \underline{\text { Site } 11}$

Rob Fendick/Roland W. Tollett

Latitude: $\frac{310220}{1400}$ Longitude: $\quad 930015 \pm 32 \mathrm{ft}$

Weather Conditions: Partly cloudy Time: 1400

Stage: $2 / 3$ bank full, falling

concrete bridge on Lookout Road

$-300 \mathrm{ft}$ downstream of the reference location

$15 \mathrm{ft} \times 10$ (20 recommended) $=$ reach length

none 11. Reach length: $150 \mathrm{ft}$
meandering/slightly cutting banks

Transects

13. Distance from center of reach $(\mathrm{ft}) \overline{75}$

Upstream - T1

14. Channel width $(\mathrm{ft})$

15. Bank width (ft)

16. Flood-plain width
Center - T2

$\frac{0}{15} \frac{0}{\text { no data }}$

Downstream - T3

75

15 no data

Center Transect - T2 Latitude 310218 Longitude $930014 \pm 30 \mathrm{ft}$

Distances from left bank edge.

17. Depth (feet)

18. Velocity ( $\mathrm{ft} / \mathrm{s})$

19. Bed substrate

20. Embeddedness

\begin{tabular}{|c|c|}
\hline$\overline{\mathrm{LB}}$ & $3.75^{\prime}$ \\
\hline 0 & 2.4 \\
\hline$\overline{0}$ & 1.201 \\
\hline SI/SA & SI/SA \\
\hline none & none \\
\hline
\end{tabular}

\begin{tabular}{c}
\hline 7.5 \\
\hline 2.8 \\
\hline 1.501 \\
\hline SI/SA \\
\hline none \\
\hline Transects
\end{tabular}

\begin{tabular}{c}
$\frac{11.25}{2.9}$ \\
\hline 1.480 \\
\hline SI/SA \\
\hline none
\end{tabular}

\begin{tabular}{|c|}
\hline$\overline{\mathrm{RB}}$ \\
\hline$\overline{0}$ \\
\hline$\overline{0}$ \\
\hline SI/SA \\
\hline none \\
\hline
\end{tabular}

21. Canopy angle (degrees)

$\frac{\text { Upstream - T1 }}{10}$

22. Aspect (azimuth - 360 degrees)

23. Habitat features

24. Bar/shelf/island

LB-left bank/RB-right bank

25. Bank angle (degrees)

26. Bank height ( $\mathrm{ft}$ )

27. Bank vegetation stability

28. Bank shape

29. Bank erosion

30. Bank substrate

31. Woody vegetation

30

WD/OV/UB/MS

none

LB

150

5.5

Center - T2

Downstream - T3

0

4.5

3

SCB

180

10

$\underline{\text { SI/SA }} \frac{\text { SI/SA }}{\text { heB }}$

WD/OV/UB/MS

110

WD/OV/UB/MS

none

$\mathrm{hd} / \mathrm{sh}$

$\mathrm{hd} / \mathrm{sh}$

$\frac{\mathrm{LB}}{145}$
$\frac{5.5}{3}$
$\frac{\mathrm{CV}}{\mathrm{SCB}}$
$\frac{\mathrm{SA}}{\mathrm{hd} / \mathrm{sh}}$

RB

135

7.0

3

CV

SA

$\mathrm{hd} / \mathrm{sh}$

\begin{tabular}{|c|c|}
\hline none & \\
\hline$\overline{L B}$ & RB \\
\hline 125 & 135 \\
\hline 5.0 & 6.0 \\
\hline 3 & 3 \\
\hline$\overline{\mathrm{CV}}$ & $\overline{\mathrm{CV}}$ \\
\hline SCB & $\overline{\mathrm{SCB}}$ \\
\hline SA/SI & SA/SI \\
\hline $\mathrm{hd} / \mathrm{sh}$ & $\mathrm{hd} / \mathrm{sh}$ \\
\hline
\end{tabular}

32. Photodocumentation

(center transect)

33. Diagrammatic map

upstream/left bank/downstream/right bank (clockwise)

refer to following page

34. Aquatic and riparian vegetation species - Refer to Appendicies B and C.

35. Comments

secchi disk (light penetration) $=1.8 \mathrm{ft}$

\section{SECOND-LEVEL REACH CHARACTERIZATION}

Microhabitat characterization

Benthic invertabrate communities Refer to work in Appendix C by Dr. Vidrine.

Fish communities

Refer to previous work.

Figure 22. Stream characterization form for site 11 in the Limited Use Area, Vernon Ranger

District, Kisatchie National Forest, Louisiana--Continued. 


\section{SITE SKETCH}

Site 11. West Fork of Sixmile Creek north of Pitkin $400 \mathrm{ft}$ south of bridge H-9 on Lookout Road.

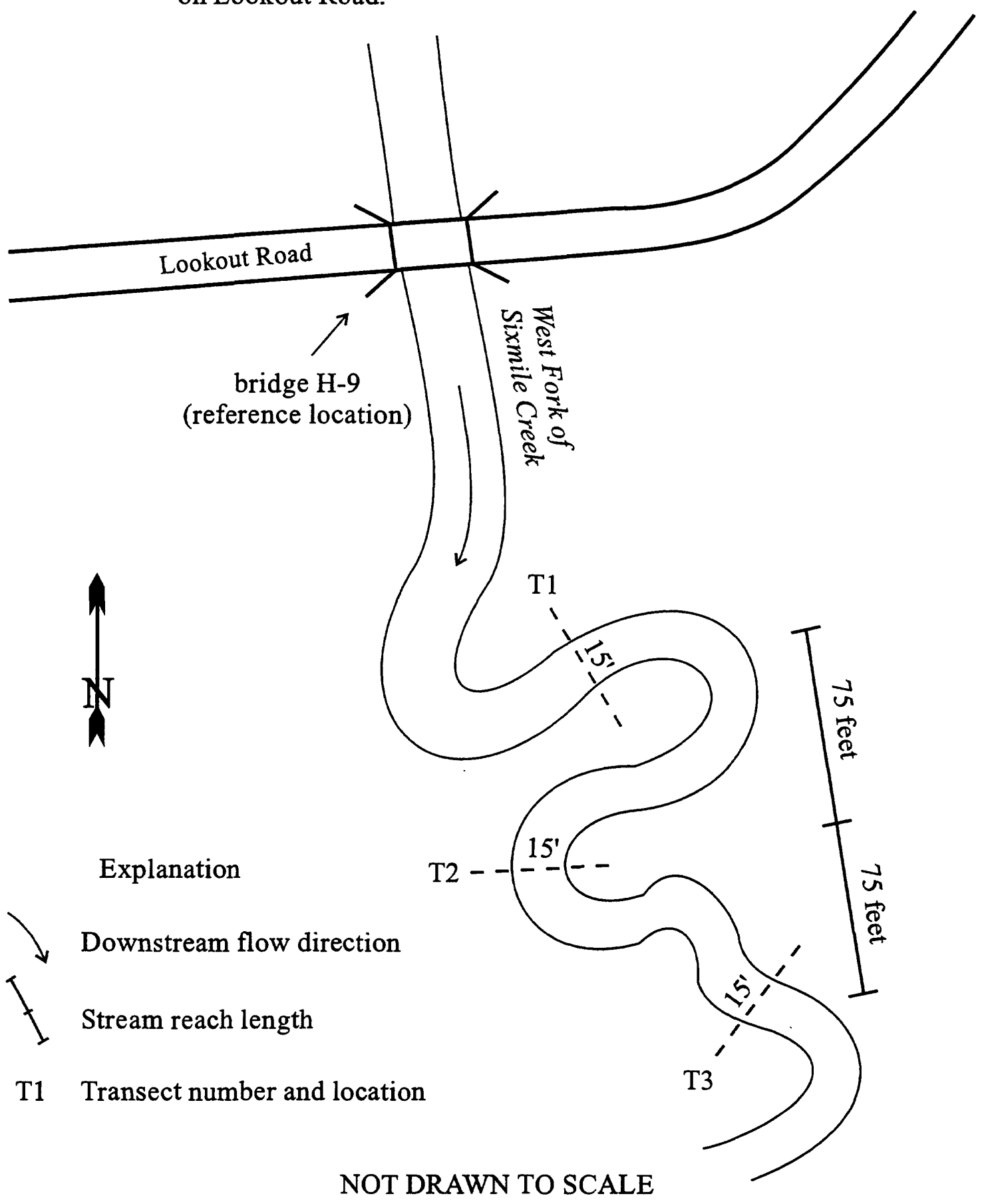

Figure 22. Stream characterization form for site 11 in the Limited Use Area, Vernon Ranger District, Kisatchie National Forest, Louisiana--Continued. 


\section{STREAM CHARACTERIZATION FORM}

\section{BASIN CHARACTERIZATION}

1. Study unit

3. Station name

4. Station identification

5. Investigators

6. Reference location (Fullerton Lake)

7. Drainage area for West Fork Creek

north of site 12

(map scale 1:50000)

8. Drainage density

10. Drainage Shape

12. Basin relief above site 10 (north)

14. Ecoregion $(1: 2,500,000)$

15. Physiographic province

16. Land use

17. Geologic type

(map scale 1:500,000)

18. Soil type

19. Potential natural vegetation

20. Wetlands (bogs)

21. Mean annual precipitation
$\mathrm{ACAD}$

2. Date: November 1996 - February 1997

West Fork of Sixmile Creek $750 \mathrm{ft}$ west of Fullerton Lake.

Downstream order number: none

C. R. Demas, R. B. Fendick, R. W. Tollett

Latitude: $310100 \quad$ Longitude: 925900

$62.8 \mathrm{sg} \mathrm{km}$ $24.2 \mathrm{sq} \mathrm{mi}$ 15512 acres

\begin{tabular}{l} 
Not determined \\
\hline .7 \\
\hline South Central Plains \\
\hline West Gulf Coastal Plain
\end{tabular}

9. Drainage Texture Not determined

11. Stream length

13. Storage

Not determined $19.9 \mathrm{~km}$

West Gulf Coastal Plain

FO - Deciduous forest land (De) and Evergreens (Ev)

Qth-High terraces The Pleistocene terrace deposits unconformably overlay the Pliocene-Pleistocene deposits of the the Blounts Creek Member of the Fleming Formation. High terrace deposits are defined as tan to orange clay, silt, and sand with large amounts of basal gravel.

Mfb-Blounts Creek Member The Blounts Creek Member of the Fleming Formation overlies the Castor Creek Member. Blounts Creek Member is described as a gray to green silty clays, siltstones, and silts with abundant sand beds wih some lignite and lenses of black chert gravel.

moist ultisols (udults)

oak/hickory/pine - woodland and forest w/some cropland and pasture

Refer to figure 2 for bog locations, and Appendix C for descriptions. Over the past 5 years, mean annual precipitation was $58.3 \mathrm{in} / \mathrm{yr}$.

\section{SEGMENT CHARACTERIZATION}

1. Study unit

3. Station name

4. Station identification

5. Investigators

6. Reference location (Fullerton Lake)

7. State

9. Township

11. Section

12. Quadrangle

13. Segment code

14. Segment length (1:50000)

15. Elevation of site 12

16. Sideslope gradient

17. Segment gradient

18. Channel sinuosity (1:50000)

19. Stream order

21. Water management feature
ACAD

2. Date: November 1996 - February 1997

West Fork of Sixmile Creek $\sim 750 \mathrm{ft}$ west of Fullerton Lake.

Downstream order number: none

C. R. Demas, R. B. Fendick, R. W. Tollett

Latitude: $310100 \quad$ Longitude: 925900

Louisiana
8. Parish Vernon
10. Range

T. $1 \mathrm{~S}$

SE $1 / 4$, NW1/4, section 4

FULLERTON LAKE QUADRANGLE - 7.5 Minute Series (Topographic)

Not determined

Stream length above site 12 is $19.9 \mathrm{~km}$.

$181 \mathrm{ft}$ or $55 \mathrm{~m}$ (elevation of land near site 12)

Not determined

0.003

1.4

2

None

20. Downstream link 3

Figure 23. Stream characterization form for site 12 in the Limited Use Area, Vernon Ranger

District, Kisatchie National Forest, Louisiana. 


\section{FIRST-LEVEL REACH CHARACTERIZATION}

1. Study unit

3. Station name

4. Station identification

5. Investigators

6. Reference location

7. Reference location description

8. Upstream reach boundary (T1) nearest to reference location

9. Channel width at reach boundary

10. Geomorphic channel units

12. Stream type
$\mathrm{ACAD}$

2. Date:

Wed, March 5, 1997

West Fork of Sixmile Creek $~ 750 \mathrm{ft}$ west of Fullerton Lake.

Downstream order number: none

Site 12

Rob Fendick/Roland W. Tollett

$$
\text { Latitude: } \frac{310100}{100} \text { Longitude: } 925900
$$

Weather Conditions: Partly cloudy Time: 1000

Stage: $2 / 3$ bank full/falling

$\mathrm{N}-\mathrm{S}$ trending levee on the west bank of Fullerton Lake

about $750 \mathrm{ft}$ west of the reference location

$20 \mathrm{ft} \times 10(20$ recommended $)=$ reach length

\begin{tabular}{l} 
none 11. Reach length: $200 \mathrm{ft}$ \\
\hline meandering/slightly cutting banks
\end{tabular}

Transects

13. Distance from center of reach (ft) 100

Upstream - T1

Center - T2

no data

0

$\frac{19}{\text { no data }}$

Downstream - T3

14. Channel width (ft)

15. Bank width ( $\mathrm{ft}$ )

16. Flood-plain width

$\mathrm{LB}>50 \mathrm{~m}, \mathrm{RB}>50 \mathrm{~m}$

100

15

no data

Center Transect - T2 Latitude 310030 Longitude $925919 \pm 24 \mathrm{ft}$

Distances from left bank edge.

17. Depth (feet)

18. Velocity $(\mathrm{ft} / \mathrm{s})$

19. Bed substrate

20. Embeddedness

$\frac{\frac{\mathrm{LB}}{0}}{\frac{0}{\frac{\text { SA/SI }}{\text { none }}} \frac{5.0^{\prime}}{\frac{1.8}{0.769}} \frac{\text { SA }}{\text { none }}}$

\begin{tabular}{|c|c|c|}
\hline $10.0^{\prime}$ & $15.0^{\prime}$ & $\overline{\mathrm{RB}}$ \\
\hline 4.0 & 4.5 & 0 \\
\hline 1.170 & 0.941 & $\overline{0}$ \\
\hline SA & $\overline{S A}$ & SA/SI \\
\hline none & none & none \\
\hline
\end{tabular}

21. Canopy angle (degrees)

22. Aspect (azimuth - 360 degrees)

23. Habitat features

24. Bar/shelf/island

LB-left bank/RB-right bank

25. Bank angle (degrees)

26. Bank height $(\mathrm{ft})$

27. Bank vegetation stability

28. Bank shape

29. Bank erosion

30. Bank substrate

31. Woody vegetation

32. Photodocumentation

(center transect)

33. Diagrammatic map

$\frac{\text { Upstream - T1 }}{\frac{30}{25}}$

Center - T2

\begin{tabular}{|c|c|}
\hline Downs & $-\mathrm{T} 3$ \\
\hline 0 & \\
\hline 70 & \\
\hline $\mathrm{WD} / \mathrm{O}$ & MS \\
\hline none & \\
\hline $\mathrm{LB}$ & $\mathrm{RB}$ \\
\hline 150 & 135 \\
\hline 5.5 & 6.0 \\
\hline 3 & 3 \\
\hline $\mathrm{CV}$ & CV \\
\hline SCB & SCB \\
\hline SI/SA & SU/SA \\
\hline $\mathrm{hd} / \mathrm{sh}$ & $\mathrm{hd} / \mathrm{sh}$ \\
\hline
\end{tabular}

34. Aquatic and riparian vegetation species - Refer to Appendicies B and C.

35. Comments

secchi disk (light penetration) $=2.6 \mathrm{ft}$

\section{SECOND-LEVEL REACH CHARACTERIZATION}

Microhabitat characterization

Benthic invertabrate communities Refer to work in Appendix C by Dr. Vidrine.

Fish communities

Refer to previous work.

Figure 23. Stream characterization form for site 12 in the Limited Use Area, Vernon Ranger

District, Kisatchie National Forest, Louisiana--Continued. 


\section{SITE SKETCH}

Site 12. West Fork of Sixmile Creek $\sim 750 \mathrm{ft}$ west of Fullerton Lake.
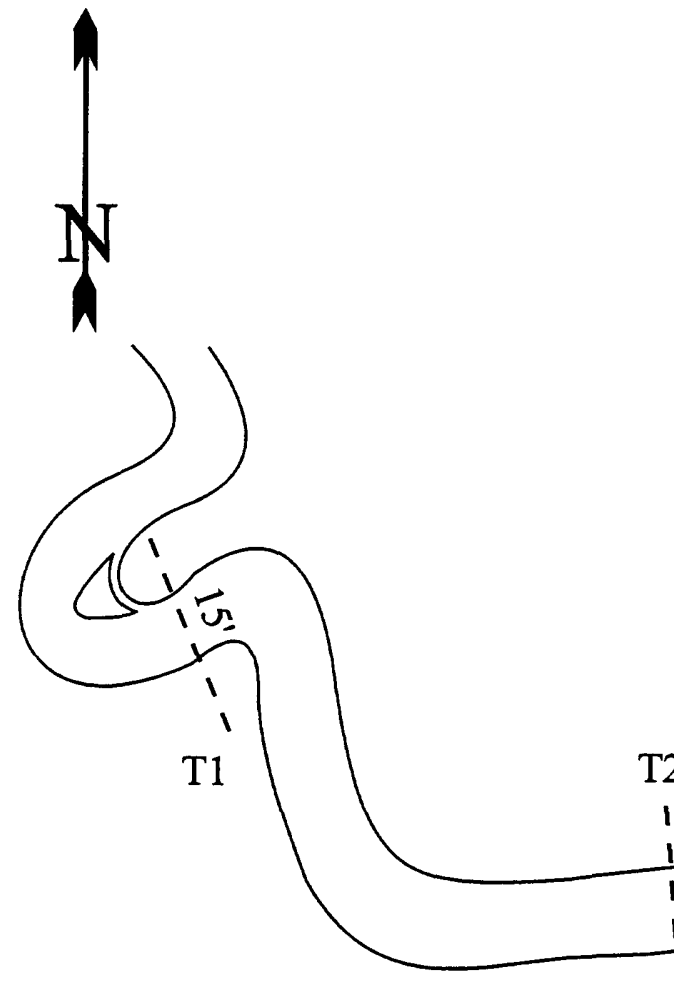

$\sim 750 \mathrm{ft}$ to Fullerton Lake (reference location)

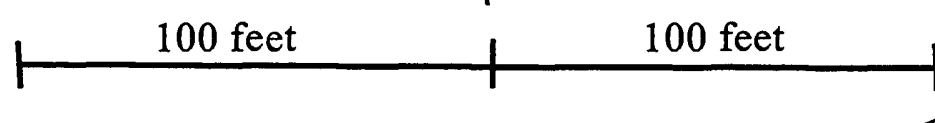

Explanation

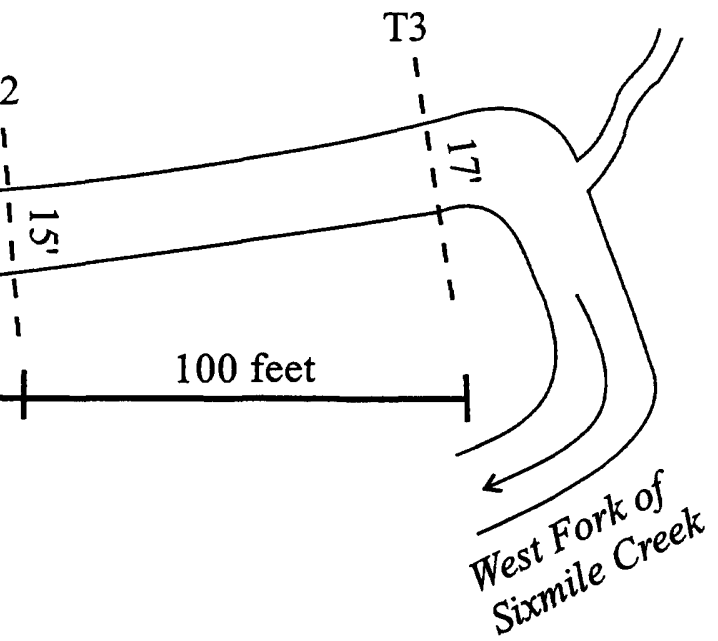

$\searrow$ Downstream flow direction

Stream reach length

T1 Transect number and location

NOT DRAWN TO SCALE

Figure 23. Stream characterization form for site 12 in the Limited Use Area, Vernon Ranger District, Kisatchie National Forest, Louisiana--Continued. 
1. Study unit

3. Station name

4. Station identification

5. Investigators

6. Reference location (bridge)

7. Drainage area for East Fork Creek north of bridge on Lookout road (map scale 1:50000)

8. Drainage density

10. Drainage Shape

12. Basin relief above site 10 (north)

14. Ecoregion $(1: 2,500,000)$

15. Physiographic province

16. Land use

17. Geologic type (map scale 1:500,000)

18. Soil type

19. Potential natural vegetation

20. Wetlands (bogs)

21. Mean annual precipitation
$\mathrm{ACAD}$

2. Date: November 1996 - February 1997

East Fork of Sixmile Creek north of Pitkin $~ 250 \mathrm{ft}$ south of bridge on Lookout Road. Downstream order number: $\underline{08013880}$ Site 13

C. R. Demas, R. B. Fendick, R. W. Tollett

Latitude: $310204 \quad$ Longitude: $925801 \pm 33 \mathrm{ft}$

$51.4 \mathrm{sq} \mathrm{km}$

$19.8 \mathrm{sg} \mathrm{mi}$

12700 acres

Not determined

3.1

9. Drainage Texture

11. Stream length

13. Storage

Not determined

$115 \mathrm{~m}-60 \mathrm{~m}=55 \mathrm{~m}$

South Central Plains

West Gulf Coastal Plain

FO - Deciduous forest land (De) and Evergreens (Ev)

Qth-High terraces The Pleistocene terrace deposits unconformably overlay the Pliocene-Pleistocene deposits of the the Blounts Creek Member of the Fleming Formation. High terrace deposits are defined as tan to orange clay, silt, and sand with large amounts of basal gravel.

Mfb-Blounts Creek Member The Blounts Creek Member of the Fleming Formation overlies the Castor Creek Member. Blounts Creek Member is described as a gray to green silty clays, siltstones, and silts with abundant sand beds wih some lignite and lenses of black chert gravel.

moist ultisols (udults)

oak/hickory/pine - woodland and forest w/some cropland and pasture

Refer to figure 2 for bog locations, and Appendix $\mathrm{C}$ for descriptions.

Over the past 5 years, mean annual precipitation was $58.3 \mathrm{in} / \mathrm{yr}$.

\section{SEGMENT CHARACTERIZATION}

1. Study unit

3. Station name

4. Station identification

5. Investigators

6. Reference location (bridge)

7. State

9. Township

11. Section

12. Quadrangle

13. Segment code

14. Segment length $(1: 50000)$

15. Elevation of reference location

16. Sideslope gradient

17. Segment gradient

18. Channel sinuosity (1:50000)

19. Stream order

21. Water management feature
$\mathrm{ACAD}$

2. Date: November 1996 - February 1997

East Fork of Sixmile Creek north of Pitkin $\sim 250 \mathrm{ft}$ south of bridge on Lookout Road. Downstream order number: $\underline{08013880}$ Site 13

C. R. Demas, R. B. Fendick, R. W. Tollett

Latitude: $310204 \quad$ Longitude: $925801 \pm 33 \mathrm{ft}$

Louisiana 8. Parish Vernon

T. $1 \mathrm{~N}$

NE 1/4, SE1/4, section 27

FULLERTON LAKE QUADRANGLE - 7.5 Minute Series (Topographic)

Not determined

Stream length above site 13 is $14.7 \mathrm{~km}$.

$195 \mathrm{ft}$ or $59 \mathrm{~m}$ (land surface elevation at bridge)

Not determined

0.0044

1.3

2

None

Figure 24. Stream characterization form for site 13 in the Limited Use Area, Vernon Ranger District, Kisatchie National Forest, Louisiana. 


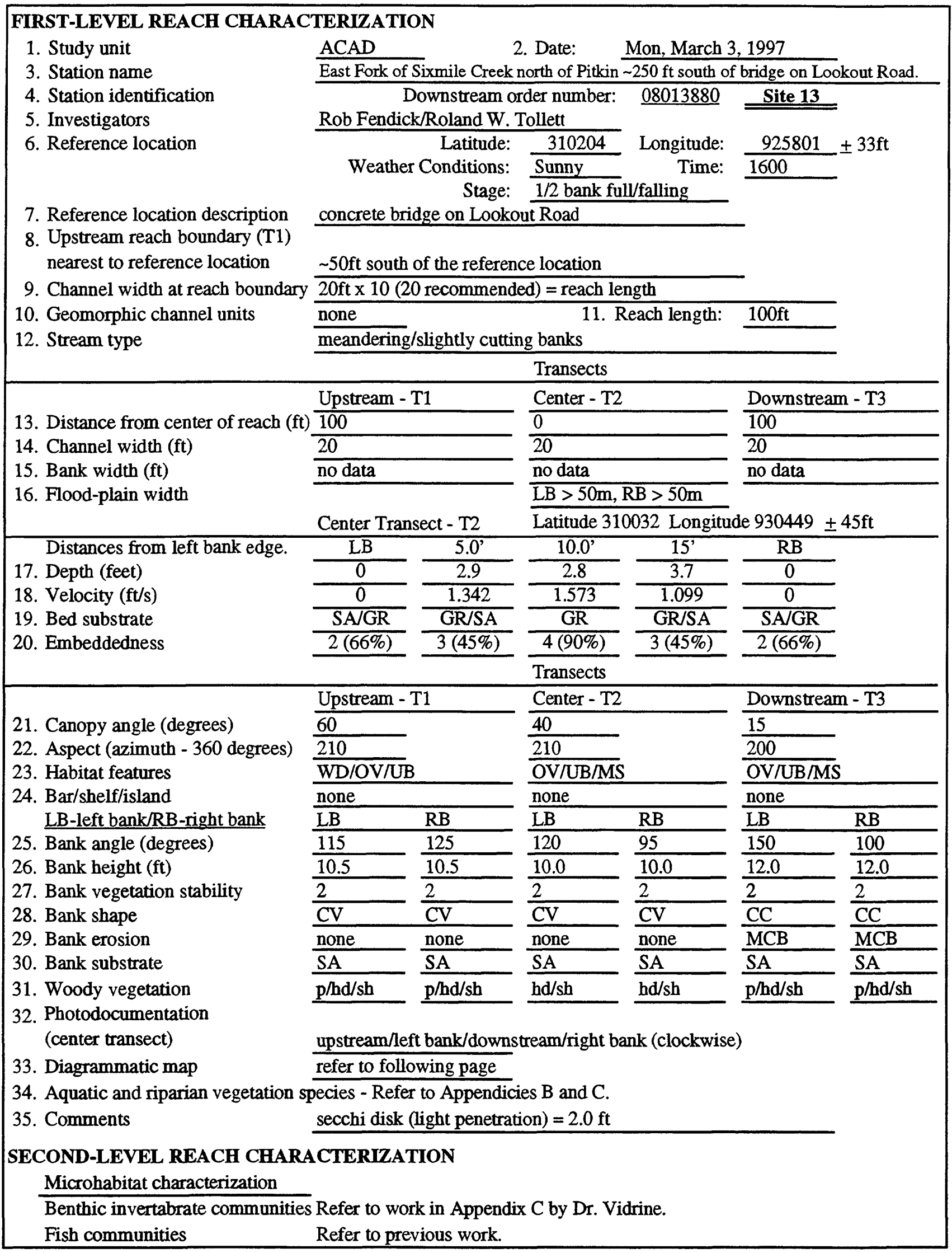

Figure 24. Stream characterization form for site 13 in the Limited Use Area, Vernon Ranger District, Kisatchie National Forest, Louisiana--Continued. 


\section{SITE SKETCH}

Site 13. East Fork of Sixmile Creek north of Pitkin $\sim 250 \mathrm{ft}$ south of bridge on Lookout Road.
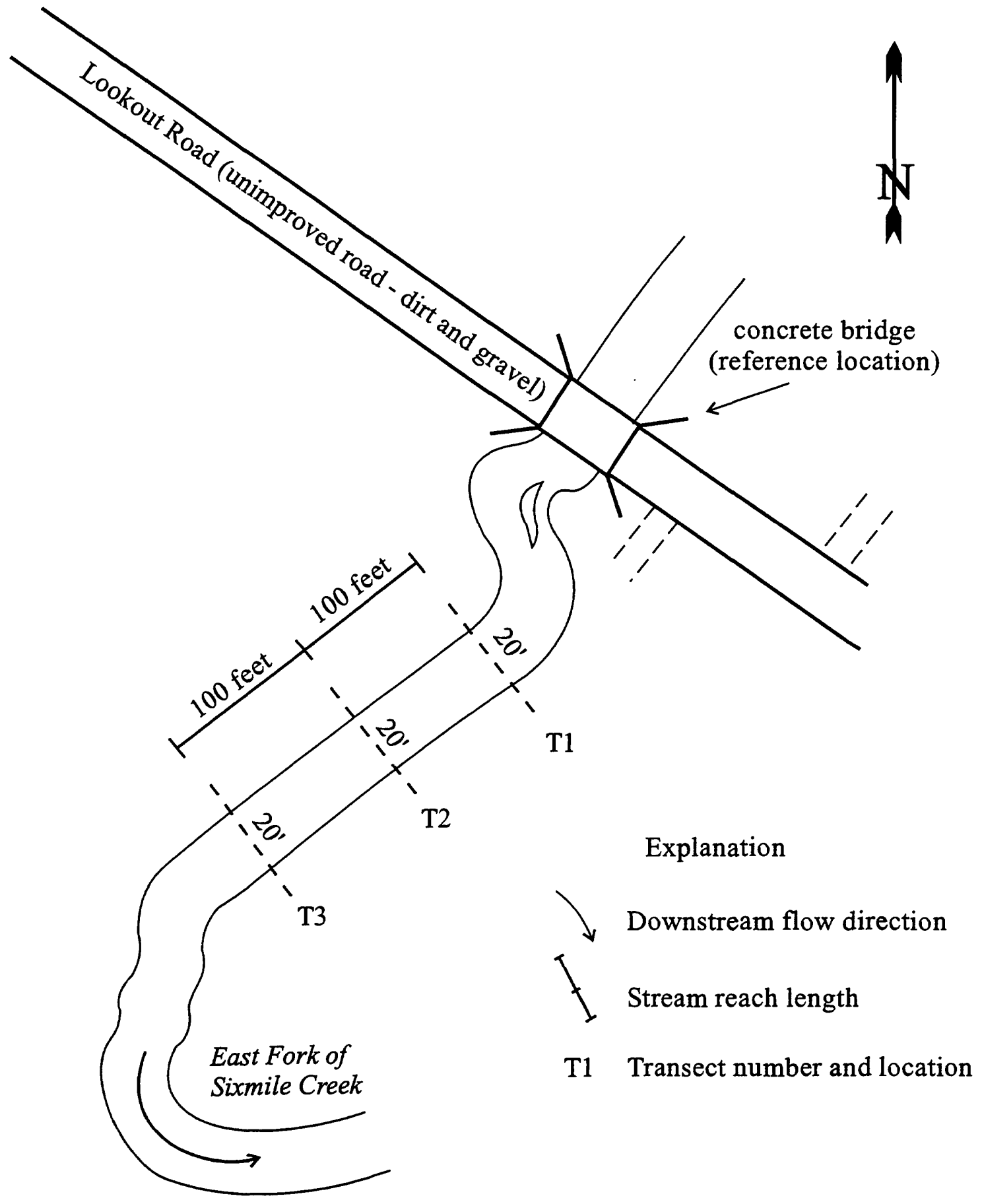

NOT DRAWN TO SCALE

Figure 24. Stream characterization form for site 13 in the Limited Use Area, Vernon Ranger District, Kisatchie National Forest, Louisiana--Continued. 


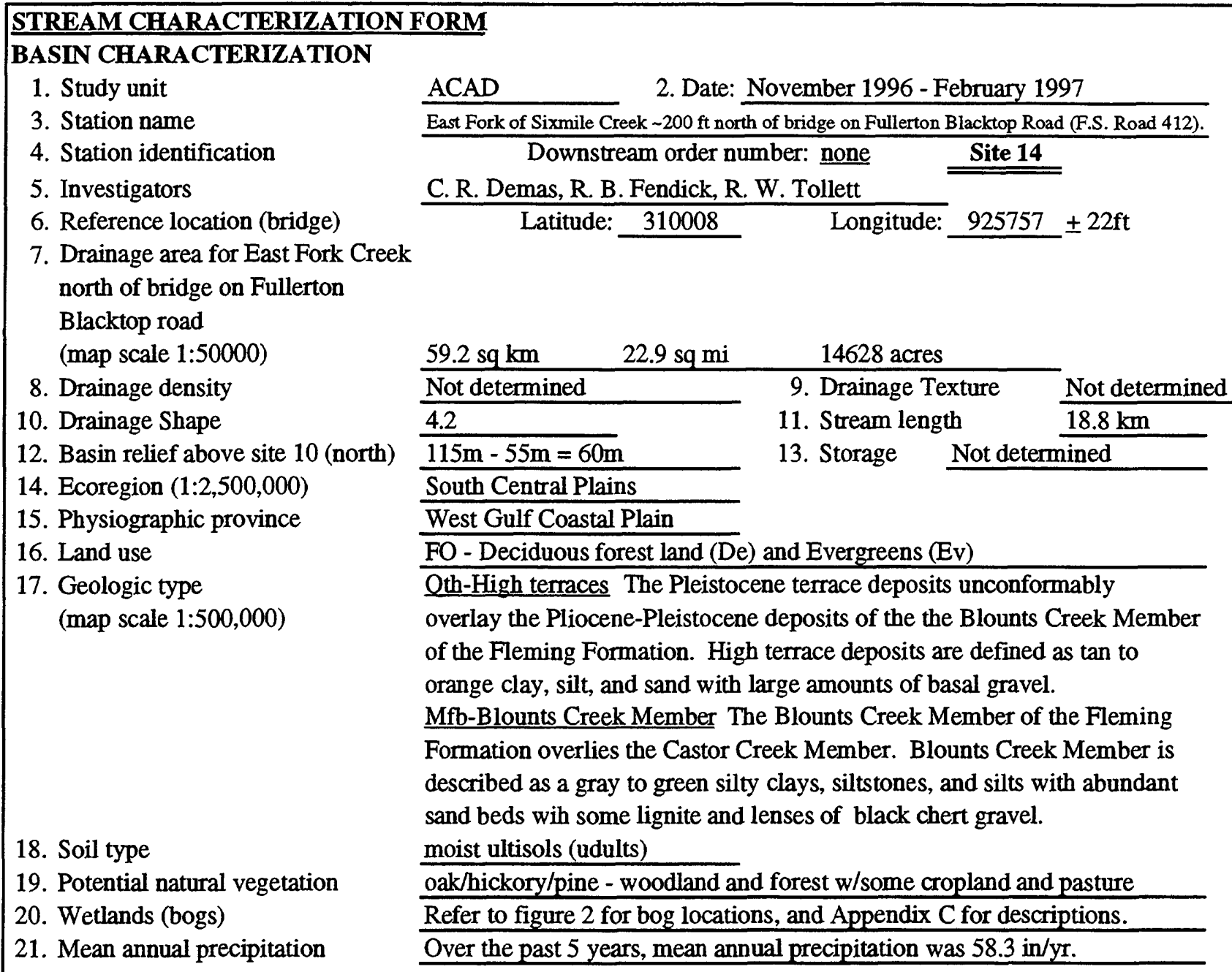

\section{SEGMENT CHARACTERIZATION}

1. Study unit

3. Station name

4. Station identification

5. Investigators

6. Reference location (bridge)

7. State

9. Township

11. Section

12. Quadrangle

13. Segment code

14. Segment length (1:50000)

15. Elevation of reference location

16. Sideslope gradient

17. Segment gradient

18. Channel sinuosity (1:50000)

19. Stream order

21. Water management feature
ACAD

2. Date: November 1996 - February 1997

East Fork of Sixmile Creek $200 \mathrm{ft}$ north of bridge on Fullerton Blacktop Road (F.S. Road 412). Downstream order number: none $\quad$ Site 14

C. R. Demas, R. B. Fendick, R. W. Tollett

Latitude: $310008 \quad$ Longitude: $925757 \pm 22 \mathrm{ft}$

Louisiana 8. Parish Vernon

T.1S 10. Range R.6W

NE $1 / 4$, SE1/4, section 3

FULLERTON LAKE QUADRANGLE - 7.5 Minute Series (Topographic)

Not determined

Stream length above site 14 is $18.8 \mathrm{~km}$.

$195 \mathrm{ft}$ or $59 \mathrm{~m}$ (land surface elevation at bridge)

Not determined

0.0038

$\frac{1.3}{2}$

20. Downstream link 3

Figure 25. Stream characterization form for site 14 in the Limited Use Area, Vernon Ranger

District, Kisatchie National Forest, Louisiana. 


\section{FIRST-LEVEL REACH CHARACTERIZATION}

1. Study unit

3. Station name

4. Station identification

5. Investigators

6. Reference location

7. Reference location description

8. Downstream reach boundary
ACAD 2. Date: $\quad$ Mon, March 3, 1997

East Fork of Sixmile Creek $\sim 200 \mathrm{ft}$ north of bridge on Fullerton Blacktop Road (F.S. Road 412). Downstream order number: none

Rob Fendick/Roland W. Tollett Latitude: $\frac{310008}{1300}$ Longitude: $\underline{925757} \pm 22 \mathrm{ft}$

Weather Conditions: Sunny Time: 1300

Stage: $1 / 2$ bank full/falling

concrete bridge on unimproved road

(T3) nearest to reference location about $200 \mathrm{ft}$ east of the reference location

9. Channel width at reach boundary $10 \mathrm{ft} \times 10(20$ recommended $)=$ reach length

10. Geomorphic channel units

12. Stream type

mone 11 . Reach length: $200 \mathrm{ft}$

Transects

13. Distance from center of reach $(\mathrm{ft})$

Upstream - T1

14. Channel width (ft)

15. Bank width (ft)

20

16. Flood-plain width

\section{Center - T2}

0

20

no data

LB > 50m, RB > 50m
Downstream - T3

100

25 no data

Center Transect - T2 Latitude 310010 Longitude $925753 \pm 30 \mathrm{ft}$

Distances from left bank edge.

17. Depth (feet)

18. Velocity ( $\mathrm{ft} / \mathrm{s}$ )

19. Bed substrate

20. Embeddedness

$\frac{\frac{\mathrm{LB}}{0} \frac{5.0^{\prime}}{\frac{4.5}{\mathrm{SA}}} \frac{1.047}{\mathrm{SA}}}{\frac{\mathrm{SA}}{\text { none }}}$

$\begin{array}{lll}10.0^{\prime} & 15.0^{\prime} & \mathrm{RB}\end{array}$

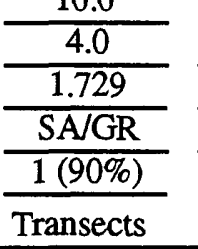

$\frac{\frac{15.0}{3.5}}{\frac{1.050}{\mathrm{SA}}}$

\begin{tabular}{c}
$\frac{\mathrm{RB}}{0}$ \\
\hline 0 \\
\hline SA \\
\hline none \\
\hline
\end{tabular}

21. Canopy angle (degrees)

22. Aspect (azimuth - 360 degrees)

23. Habitat features

24. Bar/shelf/island

LB-left bank/RB-right bank

25. Bank angle (degrees)

26. Bank height ( $\mathrm{ft}$ )

27. Bank vegetation stability

28. Bank shape

29. Bank erosion

30. Bank substrate

31. Woody vegetation

32. Photodocumentation (center transect)

33. Diagrammatic map

Upstream - T1

25

215

WD/OV/UB/MS

gravel bar - LB

LB

RB

$130-110$

7.0

3

Center - T2

Downstream - T3

0

235

WD/OV/UB/MS

none

LB

110

$\frac{110}{7.5}$

$\mathrm{CC}$

3

$\mathrm{MCB}$

$\mathrm{CV}$

SA

$\mathrm{p} / \mathrm{hd} / \mathrm{sh}$

SCB

SA

7.5

$\frac{3}{\mathrm{CC}}$

$\mathrm{CC}$

50

240

WD/OV/UB/MS

none

LB

$\mathrm{RB}$

130

7.0

3

$\mathrm{CV}$

MCB

SCB

$\mathrm{SA} / \mathrm{hd} / \mathrm{sh}$

SA

$\mathrm{p} / \mathrm{hd} / \mathrm{sh}$

$\mathrm{p} / \mathrm{hd} / \mathrm{sh}$

$\frac{\mathrm{LB}}{150}$

$\frac{150}{7.0}$

3

CV

SCB

SA/GR

$\mathrm{p} / \mathrm{hd} / \mathrm{sh}$

$\frac{\mathrm{RB}}{135}$
$\frac{7.0}{3}$
$\frac{\mathrm{CV}}{\mathrm{SCB}}$
$\frac{\mathrm{SA} / \mathrm{GR}}{\mathrm{p} / \mathrm{hd} / \mathrm{sh}}$

upstream/upstream/downstream at downstream transect (T3)

refer to following page

34. Aquatic and riparian vegetation species - Refer to Appendicies B and C.

35. Comments

secchi disk (light penetration $)=$ to depth $(2.3 \mathrm{ft})$

\section{SECOND-LEVEL REACH CHARACTERIZATION}

Microhabitat characterization

Benthic invertabrate communities Refer to work in Appendix C by Dr. Vidrine.

Fish communities

Refer to previous work.

Figure 25. Stream characterization form for site 14 in the Limited Use Area, Vernon Ranger

District, Kisatchie National Forest, Louisiana--Continued. 


\section{SITE SKETCH}

Site 14. East Fork of Sixmile Creek $\sim 300 \mathrm{ft}$ northeast of bridge on Fullerton Blacktop Road east of Leesville.
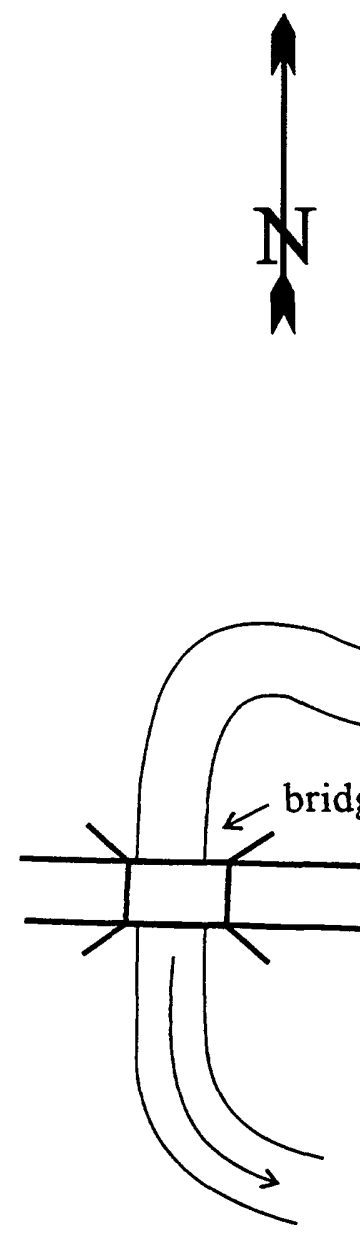

East Fork of Sixmile Creek

ridge (reference location)

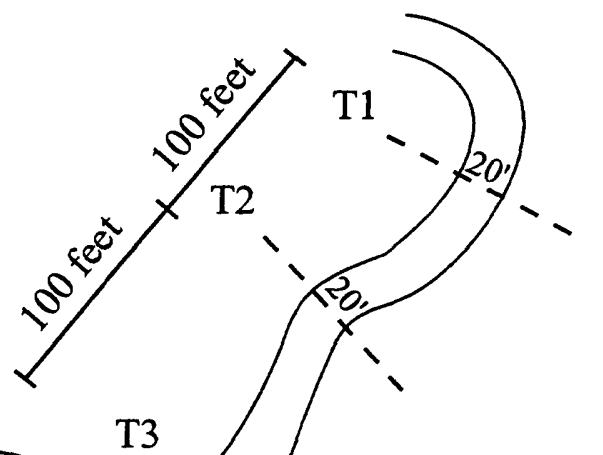

Explanation

$\searrow$ Downstream flow direction

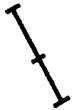

Stream reach length

T1 Transect number and location

NOT DRAWN TO SCALE

Figure 25. Stream characterization form for site 14 in the Limited Use Area, Vernon Ranger District, Kisatchie National Forest, Louisiana--Continued. 
TABLES 2-19 
Table 2. Basin areas, lengths, elevations, and gradients for Bundick Creek, Drakes Creek, Whiskey Chitto Creek, Birds Creek, Little Sixmile Creek, and West and East Fork of Sixmile Creek in the Vernon Ranger District, Kisatchie National Forest, Louisiana

[sq km, square kilometers; sq mi, square miles; km, kilometers; mi, miles; LUA, Limited Use Area; EOD, explosive ordinance disposal range]

\begin{tabular}{|c|c|c|c|c|c|c|}
\hline \multirow[b]{2}{*}{ Basin } & \multicolumn{3}{|c|}{ Area } & \multirow{2}{*}{\multicolumn{2}{|c|}{$\begin{array}{l}\text { Basin length Elevation } \\
\text { along creek difference } \\
(\mathrm{km}) \\
\text { (mi) }\end{array}$}} & \multirow[t]{2}{*}{$\begin{array}{c}\text { Basin } \\
\text { gradient }\end{array}$} \\
\hline & $\mathrm{sq} \mathrm{km}$ & sq mi & acres & & & \\
\hline \multicolumn{7}{|l|}{ Bundick Creek } \\
\hline Southern LUA boundary: & 77.3 & 29.8 & 19094 & 20.1 & 50 & 0.0025 \\
\hline North of outlet at site 1 : & 46.4 & 17.9 & 11464 & 12.2 & 40 & 0.0033 \\
\hline North of outlet at site 2 : & 77.3 & 29.8 & 19094 & 20.1 & 50 & 0.0025 \\
\hline North of Lookout road: & 44.3 & 17.1 & 10945 & & & \\
\hline Limited Use Area: & 31.4 & 12.1 & 7748 & & & \\
\hline Privately owned land within Limited Use Area: & 5.7 & 2.2 & 1406 & & & \\
\hline Net Limited Use Area: & 25.7 & 9.9 & 6342 & & & \\
\hline \multicolumn{7}{|l|}{ Drakes Creek } \\
\hline North of southern LUA boundary: & 127.9 & 49.4 & 31606 & 24.9 & 60 & 0.0024 \\
\hline North of outlet at site 3: & 37.9 & 14.6 & 9365 & 11.0 & 45 & 0.0041 \\
\hline North of outlet at site 4: & 55.5 & 21.4 & 13707 & 16.0 & 50 & 0.0031 \\
\hline North of outlet at site $5:$ & 84.7 & 32.7 & 20935 & 19.7 & 55 & 0.0028 \\
\hline North of Lookout road: & 39.0 & 15.0 & 9629 & & & \\
\hline Limited Use Area: & 89.0 & 34.3 & 21980 & & & \\
\hline Privately owned land within Limited Use Area: & 15.5 & 6.0 & 3827 & & & \\
\hline Net Limited Use Area: & 73.5 & 28.4 & 18153 & & & \\
\hline \multicolumn{7}{|l|}{ Whiskey Chitto Creek } \\
\hline North of southern LUA boundary: & 157.7 & 60.9 & 38963 & 28.4 & 65 & 0.0023 \\
\hline North of outlet at site $6:$ & 74.2 & 28.7 & 18341 & 20.6 & 56 & 0.0027 \\
\hline North of outlet at site 7 : & 145.3 & 56.1 & 35901 & 25.6 & 59 & 0.0023 \\
\hline North of outlet at site 8: & 150.8 & 58.2 & 37253 & 26.3 & 62 & 0.0024 \\
\hline North of Lookout road: & 73.6 & 28.4 & 18177 & & & \\
\hline EOD Range: & 0.8 & 0.3 & 188 & & & \\
\hline Limited Use Area: & 21.8 & 8.4 & 5378 & & & \\
\hline Privately owned land within Limited Use Area: & 8.3 & 3.2 & 2050 & & & \\
\hline Net Limited Use Area: & 13.5 & 5.2 & 3327 & & & \\
\hline \multicolumn{7}{|l|}{ Birds Creek } \\
\hline North of southern LUA boundary: & 61.5 & 23.7 & 15195 & 20.0 & 80 & 0.0040 \\
\hline North of outlet at site $9:$ & 56.5 & 21.8 & 13955 & 18.4 & 77 & 0.0042 \\
\hline North of Lookout road: & 56.5 & 21.8 & 13961 & & & \\
\hline Limited Use Area: & 5.6 & 2.2 & 1391 & & & \\
\hline Privately owned land within Limited Use Area: & 0.9 & 0.3 & 212 & & & \\
\hline Net Limited Use Area: & 4.8 & 1.8 & 1180 & & & \\
\hline \multicolumn{7}{|l|}{ Little Sixmile Creek } \\
\hline North of southern LUA boundary: & 20.7 & 8.0 & 5109 & 7.1 & 42 & 0.0059 \\
\hline North of outlet at site 10 : & 13.5 & 5.2 & 3324 & 6.0 & 40 & 0.0066 \\
\hline Limited Use Area: & 20.7 & 8.0 & 5115 & & & \\
\hline Privately owned land within Limited Use Area: & 1.2 & 0.5 & 297 & & & \\
\hline Net Limited Use Area: & 19.5 & 7.5 & 4818 & & & \\
\hline
\end{tabular}


Table 2. Basin areas, lengths, elevations, and gradients for Bundick Creek, Drakes Creek, Whiskey Chitto Creek, Birds Creek, Little Sixmile Creek, and West and East Fork of Sixmile Creek in the Vernon Ranger District, Kisatchie National Forest, Louisiana--Continued

\begin{tabular}{|c|c|c|c|c|c|c|}
\hline \multirow[b]{2}{*}{ Basin } & \multicolumn{3}{|c|}{ Area } & \multirow{2}{*}{\multicolumn{2}{|c|}{$\begin{array}{l}\text { Basin length Elevation } \\
\text { along creek difference } \\
(\mathrm{km})\end{array}$}} & \multirow{2}{*}{$\begin{array}{c}\text { Basin } \\
\text { gradient }\end{array}$} \\
\hline & $\mathrm{sq} \mathrm{km}$ & sq mi & acres & & & \\
\hline \multicolumn{7}{|l|}{ Sixmile Creek (including Little Sixmile Creek) } \\
\hline Total area from southern LUA boundary: & 152.8 & 59.0 & 37750 & & & \\
\hline \multicolumn{7}{|l|}{ West Fork of Sixmile Creek } \\
\hline North of southern LUA boundary: & 68.4 & 26.4 & 16909 & 23.5 & 63 & 0.0027 \\
\hline North of outlet at site 11: & 48.8 & 18.8 & 12053 & 15.1 & 55 & 0.0036 \\
\hline North of outlet at site 12 : & 62.8 & 24.2 & 15512 & 19.9 & 60 & 0.0030 \\
\hline North of Lookout road: & 47.9 & 18.5 & 11834 & & & \\
\hline Limited Use Area: & 22.0 & 8.5 & 5439 & & & \\
\hline Privately owned land within Limited Use Area: & 4.7 & 1.8 & 1157 & & & \\
\hline Net Limited Use Area: & 17.3 & 6.7 & 4281 & & & \\
\hline \multicolumn{7}{|l|}{ East Fork of Sixmile Creek } \\
\hline North of southern LUA boundary: & 60.3 & 23.3 & 14903 & 16.9 & 63 & 0.0037 \\
\hline North of outlet at site 13: & 51.4 & 19.8 & 12700 & 12.6 & 55 & 0.0044 \\
\hline North of outlet at site 14 : & 59.2 & 22.9 & 14628 & 15.8 & 60 & 0.0038 \\
\hline Area north of Lookout road: & 51.3 & 19.8 & 12677 & & & \\
\hline Limited Use Area: & 8.7 & 3.4 & 2146 & & & \\
\hline Privately owned land within Limited Use Area: & 1.4 & 0.5 & 346 & & & \\
\hline Net Limited Use Area: & 7.3 & 2.8 & 1800 & & & \\
\hline \multicolumn{7}{|c|}{ Southeast corner of the Limited Use Area not covered by sampling grid } \\
\hline Limited Use Area: & 22.5 & 8.7 & 5553 & & & \\
\hline Privately owned land within Limited Use Area: & 2.3 & 0.9 & 562 & & & \\
\hline Net Limited Use Area: & 19.1 & 7.4 & 4732 & & & \\
\hline \multicolumn{7}{|c|}{ Southwest corner of the Limited Use Area not covered by sampling grid } \\
\hline Limited Use Area: & 6.5 & 2.5 & 1602 & & & \\
\hline Privately owned land within Limited Use Area: & 3.3 & 1.3 & 821 & & & \\
\hline Net Limited Use Area: & 3.2 & 1.2 & 781 & & & \\
\hline
\end{tabular}

Summary:

Total area represented by the sampling grid

in the Environmental Assessment sampling: 133575 acres

Total Area represented by the sampling grid above

Lookout Road (Fort Polk Military Reservation): 77224 acres

Total area represented by sampling grid

within the Limited Use Area: 56351 acres

Privately owned land within Limited Use Area: 10679 acres

Net Limited Use Area available to Fort Polk: 45414 acres 
Table 3. Map symbol, name, and description of soils within the Limited Use Area, Vernon Ranger District, Kisatchie National Forest, Louisiana

\begin{tabular}{|c|c|}
\hline $\begin{array}{c}\text { Map } \\
\text { symbol }\end{array}$ & Soil name and description \\
\hline $\mathrm{BaB}$ & $\begin{array}{l}\text { Beauregard fine sandy loam, } 1 \text { to } 3 \text { percent slopes } \\
\text { This moderately well drained, very gently sloping soil is on broad areas on uplands. It is loamy } \\
\text { throughout. Runoff is slow, and water and air move slowly through the subsoil. The soil is wet for } \\
\text { long periods because of slow runoff and a seasonal high water table. }\end{array}$ \\
\hline $\mathrm{BaC}$ & $\begin{array}{l}\text { Beauregard fine sandy loam, } 3 \text { to } 5 \text { percent slopes } \\
\text { This moderately well drained, very gently sloping to gently sloping soil is on uplands. It is loamy } \\
\text { throughout and has plinthite in the lower part of the subsoil. Natural fertility is low. Runoff is medium, } \\
\text { and water and air move moderately slowly through the soil. }\end{array}$ \\
\hline BEE & $\begin{array}{l}\text { Betis loamy fine sand, } 5 \text { to } 12 \text { percent slopes } \\
\text { This somewhat excessively drained, strongly sloping to steep, sandy soil is on uplands. It has a very } \\
\text { low available water capacity and very low natural fertility. Runoff is slow. Water moves rapidly } \\
\text { through the soil. }\end{array}$ \\
\hline $\mathrm{BeC}$ & $\begin{array}{l}\text { Betis loamy fine sand, } 1 \text { to } 5 \text { percent slopes } \\
\text { This somewhat excessively drained, very gently sloping or gently sloping, sandy soil is on uplands. } \\
\text { It has a very low available water capacity and very low natural fertility. Runoff is slow. Water moves } \\
\text { rapidly through the soil. }\end{array}$ \\
\hline BoB & $\begin{array}{l}\text { Boykin loamy fine sand, I to } 3 \text { percent slopes } \\
\text { This well drained, gently sloping soil is on uplands. It has thick sandy surface and subsurface layers } \\
\text { and a loamy subsoil. Natural fertility is low. Runoff is slow. Water and air move rapidly through } \\
\text { the sandy surface and subsurface layers, and they move at a moderate rate through the loamy subsoil. } \\
\text { The available water capacity is low. }\end{array}$ \\
\hline $\mathrm{BoD}$ & $\begin{array}{l}\text { Boykin loamy fine sand, } 3 \text { to } 8 \text { percent slopes } \\
\text { This is a well drained, strongly sloping to moderately steep soil on uplands. It has thick sandy surface } \\
\text { and subsurface layers and a loamy subsoil. The soil has low fertility and a low or moderate available } \\
\text { water capacity. Permeability is rapid in the upper part of the soil and moderate in the lower part. } \\
\text { Surface runoff is medium. }\end{array}$ \\
\hline BRE & $\begin{array}{l}\text { Briley loamy fine sand, } 5 \text { to } 12 \text { percent slopes } \\
\text { This is a well drained, strongly sloping to moderately steep soil on uplands. It has thick sandy surface } \\
\text { and subsurface layers and a loamy subsoil. The soil has low fertility and a low or moderate available } \\
\text { water capacity. Permeability is rapid in the upper part of the soil and moderate in the lower part. } \\
\text { Surface runoff is medium. }\end{array}$ \\
\hline
\end{tabular}


Table 3. Map symbol, name, and description of soils within the Limited Use Area, Vernon Ranger District, Kisatchie National Forest, Louisiana--Continued

\begin{tabular}{|c|c|}
\hline $\begin{array}{c}\text { Map } \\
\text { symbol }\end{array}$ & Soil name and description \\
\hline $\mathrm{BrC}$ & $\begin{array}{l}\text { Briley loamy fine sand, } 1 \text { to } 5 \text { percent slopes } \\
\text { This well drained, gently sloping soil is on uplands. It has thick sandy surface and subsurface layers } \\
\text { and a loamy subsoil. Natural fertility is low. Runoff is slow. Water and air move rapidly through } \\
\text { the sandy surface and subsurface layers, and they move at a moderate rate throughout the loamy } \\
\text { subsoil. The available water capacity is low. }\end{array}$ \\
\hline $\mathrm{CaA}$ & $\begin{array}{l}\text { Caddo silt loam, } 0 \text { to } 1 \text { percent slopes } \\
\text { This poorly drained, level soil is on low, broad flats on uplands. Runoff is slow, and water and air } \\
\text { move slowly through the soil. The soil is wet for long periods. A seasonal high water table is near } \\
\text { the surface in winter and spring. The soil is loamy throughout. It is acid throughout and has low } \\
\text { fertility. }\end{array}$ \\
\hline $\mathrm{ChB}$ & $\begin{array}{l}\text { Cahaba fine sandy loam, } 1 \text { to } 3 \text { percent slopes } \\
\text { This well drained, very gently sloping or gently sloping soil is on low stream terraces. It is loamy } \\
\text { throughout, or it has a sandy surface layer and a loamy subsoil. Runoff is medium. Water and air } \\
\text { move at a moderate rate through the subsoil. The soil dries quickly after rains. Plants are damaged } \\
\text { by a lack of moisture during dry periods in summer and fall. }\end{array}$ \\
\hline EAE & $\begin{array}{l}\text { Eastwood silt loam, } 5 \text { to } 12 \text { percent slopes } \\
\text { This moderately well drained, moderately sloping to strongly sloping soil is on side slopes on uplands. } \\
\text { It has a loamy surface layer and a clayey subsoil. Runoff is rapid. Water and air move slowly or } \\
\text { very slowly through the subsoil. The soil is acid throughout and has low fertility. The subsoil has a } \\
\text { high shrink-swell potential. In places, the soil is moderately eroded. }\end{array}$ \\
\hline $\mathrm{EaC}$ & $\begin{array}{l}\text { Eastwood silt loam, } 1 \text { to } 5 \text { percent slopes } \\
\text { This moderately well drained, gently sloping soil is on ridgetops on uplands. It has a loamy surface } \\
\text { layer and a clayey subsoil. Runoff is medium. Water and air move slowly or very slowly through } \\
\text { the subsoil. The soil is acid throughout and has low fertility. The soil has a high shrink-swell potential. } \\
\text { In places, the soil is moderately eroded. }\end{array}$ \\
\hline GOE & $\begin{array}{l}\text { Gore very fine sandy loam, } 5 \text { to } 12 \text { percent slopes } \\
\text { This moderately well drained, moderately sloping to strongly sloping soil is on side slopes on uplands. } \\
\text { It has a loamy surface layer and a clayey subsoil. The soil is acid throughout and has low fertility. } \\
\text { Runoff is rapid, and water moves very slowly through the subsoil. The subsoil has a very high shrink- } \\
\text { swell potential. In places, the soil is moderately eroded. }\end{array}$ \\
\hline
\end{tabular}


Table 3. Map symbol, name, and description of soils within the Limited Use Area, Vernon Ranger District, Kisatchie National Forest, Louisiana--Continued

\begin{tabular}{|c|c|}
\hline $\begin{array}{c}\text { Map } \\
\text { symbol }\end{array}$ & Soil name and description \\
\hline $\mathrm{GoC}$ & $\begin{array}{l}\text { Gore very fine sandy loam, } 1 \text { to } 5 \text { percent slopes } \\
\text { This moderately well drained, very gently sloping to gently sloping soil is on uplands. It has a loamy } \\
\text { surface layer and a clayey subsoil. The soil is acid throughout and has low fertility. Runoff is medium, } \\
\text { and water moves very slowly through the subsoil. The shrink-swell potential is high or very high in } \\
\text { the subsoil. In places, the soil is moderately eroded. }\end{array}$ \\
\hline $\mathrm{GuA}$ & $\begin{array}{l}\text { Guyton silt loam, occasionally flooded } \\
\text { This level, poorly drained soil is in depressional areas. It is occasionally flooded, ponded, or otherwise } \\
\text { saturated for long periods in winter and spring. The soil is acid and loamy throughout. Natural } \\
\text { fertility is low. Permeability is slow or very slow. Runoff is very slow to ponded. The shrink-swell } \\
\text { potential is low. }\end{array}$ \\
\hline GYA & $\begin{array}{l}\text { Guyton - Iuka complex, frequently flooded } \\
\text { These level soils are on narrow flood plains. They are subject to frequent flooding. The poorly } \\
\text { drained Guyton soil is in low areas. The moderately well drained Iuka soil is on ridges and natural } \\
\text { levees. The Guyton soil is loamy throughout. It has low permeability. The Iuda soil has a loamy } \\
\text { surface layer and a sandy and loamy underlying material. Both soils have a seasonal high water table } \\
\text { in winter and spring. Natural fertility is low. }\end{array}$ \\
\hline $\mathrm{HoC}$ & $\begin{array}{l}\text { Hornbeck clay, } 1 \text { to } 5 \text { percent slopes } \\
\text { This gently sloping, moderately well drained soil is on uplands. It has a black, loamy surface layer } \\
\text { and a clayey underlying material. The underlying material is alkaline and contains accumulations of } \\
\text { lime. Natural fertility is high. Surface runoff is medium. Permeability is very slow. The shrink- } \\
\text { swell potential is high. }\end{array}$ \\
\hline $\mathrm{HoD}$ & $\begin{array}{l}\text { Hornbeck clay, } 5 \text { to } 8 \text { percent slopes } \\
\text { This moderately sloping, moderately well drained soil is on side slopes on uplands. The soil is clayey } \\
\text { throughout. It has an alkaline subsoil that contains accumulations of lime. Natural fertility is high. } \\
\text { Water and air move through the soil at a very slow rate. Surface runoff is medium. The shrink-swell } \\
\text { potential in the subsoil is high. }\end{array}$ \\
\hline $\mathrm{KcB}$ & $\begin{array}{l}\text { Kirbyville - Niwana complex } \\
\text { This complex consists of areas of very gently sloping Kirbyville and Niwana soils on uplands. The } \\
\text { Kirbyville soil is on ridgetops and side slopes. It is somewhat poorly drained. The Niwana soil is } \\
\text { on circular mounds. It is moderately well drained. Both soils are loamy throughout. Natural fertility } \\
\text { is low. Permeability is moderate. The soils have a seasonal high water table in winter and spring. }\end{array}$ \\
\hline $\mathrm{MaB}$ & $\begin{array}{l}\text { Malbis fine sandy loam, } 1 \text { to } 3 \text { percent slopes } \\
\text { This moderately well drained, very gently sloping to gently sloping soil is on uplands. It is loamy } \\
\text { throughout and has plinthite in the lower part of the subsoil. Natural fertility is low. Runoff is medium, } \\
\text { and water and air move moderately slowly through the soil. }\end{array}$ \\
\hline
\end{tabular}


Table 3. Map symbol, name, and description of soils within the Limited Use Area, Vernon Ranger District, Kisatchie National Forest, Louisiana--Continued

\begin{tabular}{|c|c|}
\hline $\begin{array}{c}\text { Map } \\
\text { symbol }\end{array}$ & Soil name and description \\
\hline $\mathrm{MaC}$ & $\begin{array}{l}\text { Malbis fine sandy loam, } 3 \text { to } 5 \text { percent slopes } \\
\text { This moderately well drained, very gently sloping to gently sloping soil is on uplands. It is loamy } \\
\text { throughout and has plinthite in the lower part of the subsoil. Natural fertility is low. Runoff is medium, } \\
\text { and water and air move moderately slowly through the soil. }\end{array}$ \\
\hline OsB & $\begin{array}{l}\text { Osier loamy fine sand, } 0 \text { to } 2 \text { percent slopes } \\
\text { These poorly drained, nearly level to moderately sloping soils are on footslopes adjacent to } \\
\text { drainageways on uplands. They have a thick, sandy surface layer and a loamy subsoil, or they are } \\
\text { sandy throughout. The soils are acid throughout and have low fertility. Runoff is medium. Water } \\
\text { seeps to the surface most of the year. }\end{array}$ \\
\hline $\mathrm{Pg}$ & $\begin{array}{l}\text { Pits } \\
\text { This map unit consists of open excavations from which sand and gravel have been removed. The } \\
\text { areas range from gently sloping to steeply sloping. They generally are barren of vegetation. }\end{array}$ \\
\hline RuB & $\begin{array}{l}\text { Ruston fine sandy loam, } 1 \text { to } 3 \text { percent slopes } \\
\text { This well drained, very gently sloping to gently sloping soil is on uplands. It is loamy and acid } \\
\text { throughout. Natural fertility is low. Runoff is medium. Water and air move through the soil at a } \\
\text { moderate rate. Plant roots penetrate this soil easily. The soil dries quickly after rains. In places, the } \\
\text { soil is moderately eroded. }\end{array}$ \\
\hline $\mathrm{RuD}$ & $\begin{array}{l}\text { Ruston fine sandy loam, } 3 \text { to } 8 \text { percent slopes } \\
\text { This well drained, gently sloping to moderately sloping soil is on uplands. It is loamy and acid } \\
\text { throughout. Natural fertility is low. Runoff is rapid. Movement of air and water through the soil is } \\
\text { moderate. Plant roots penetrate this soil easily. In places, the soil is moderately eroded. }\end{array}$ \\
\hline $\mathrm{SeC}$ & $\begin{array}{l}\text { Sawyer very fine sandy loam, } 1 \text { to } 5 \text { percent slopes } \\
\text { This moderately well drained, very gently sloping or gently sloping soil is on terraces. It is loamy in } \\
\text { the upper part of the subsoil and clayey in the lower part. Natural fertility is low or moderately low. } \\
\text { Runoff is slow to medium. Water and air move slowly or very slowly through the clayey part of the } \\
\text { subsoil. A seasonal high water table is perched on the clayey subsoil for long periods in winter and } \\
\text { spring. In places, the soil is moderately eroded. }\end{array}$ \\
\hline $\mathrm{VaC}$ & $\begin{array}{l}\text { Vaiden loam, } 1 \text { to } 5 \text { percent slopes } \\
\text { This nearly level, somewhat poorly drained soil is on broad ridgetops on uplands. It has a loamy or } \\
\text { clayey surface layer and a clayey subsoil. The soil has low natural fertility. Permeability is very } \\
\text { slow. The soil has a seasonal high water table. Surface runoff is slow. The shrink-swell potential } \\
\text { is very high in the subsoil. }\end{array}$ \\
\hline
\end{tabular}




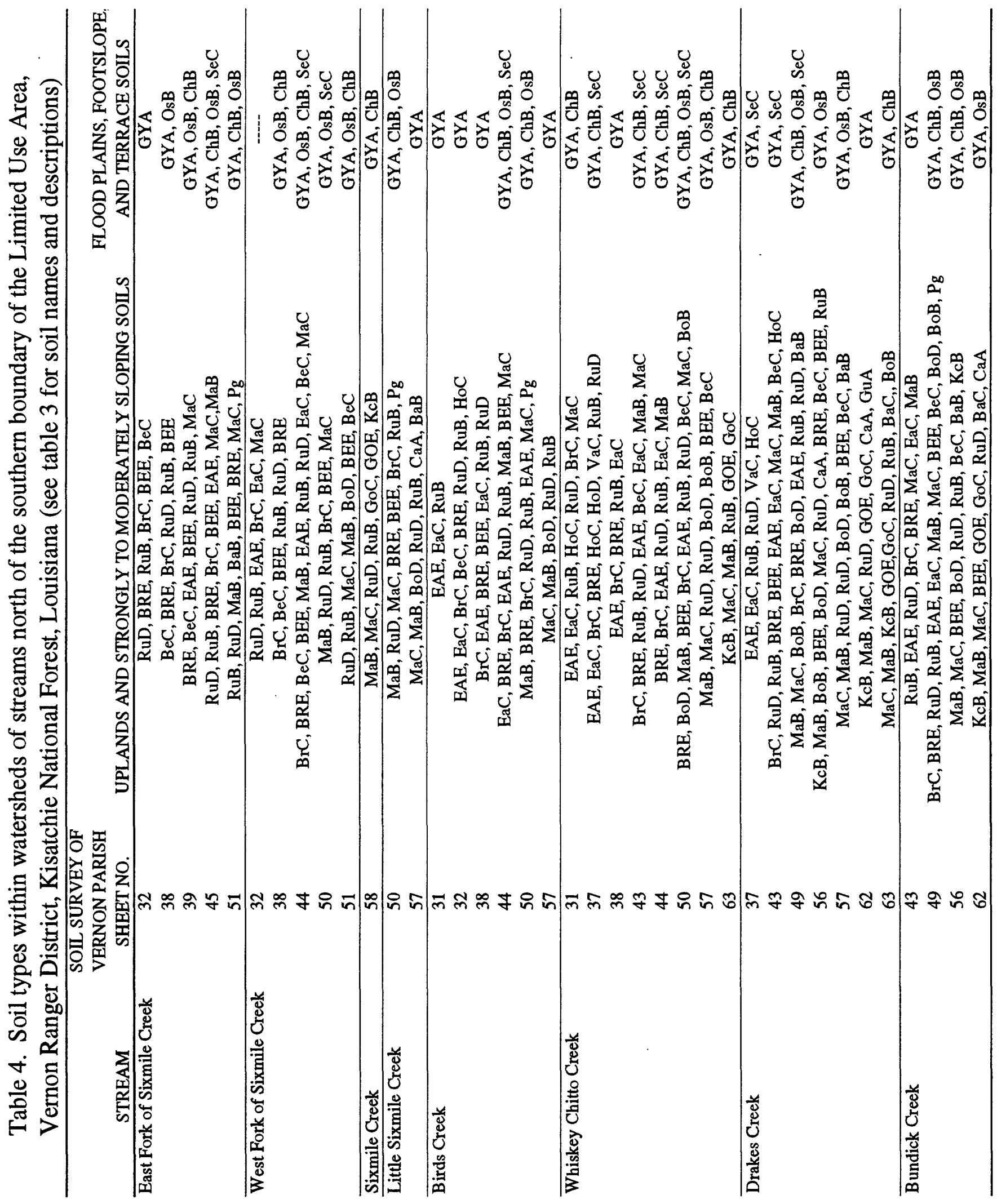




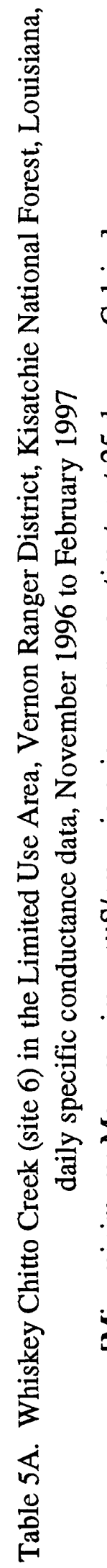

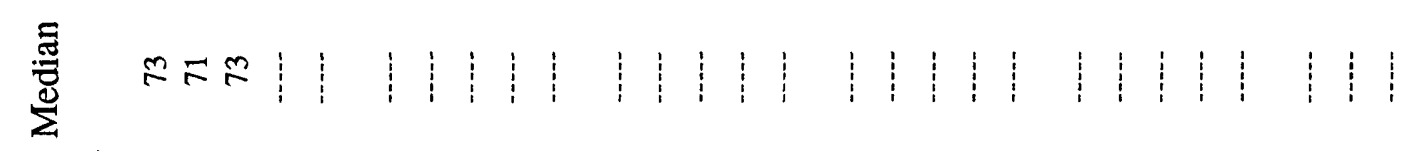

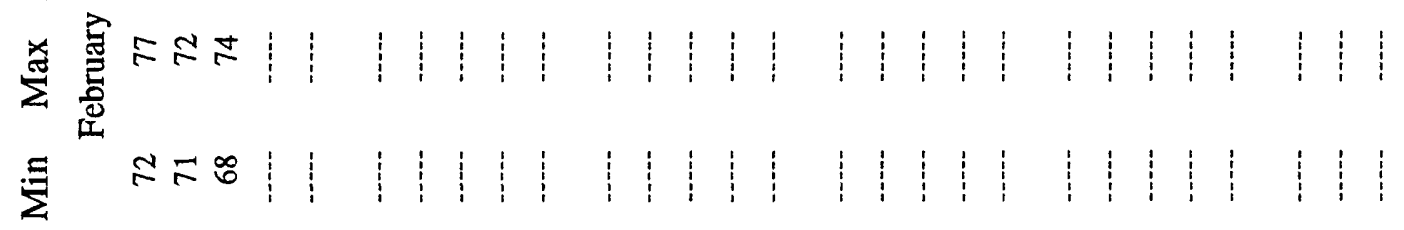

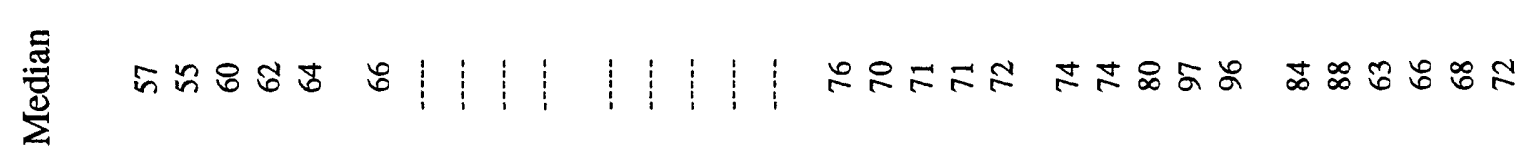

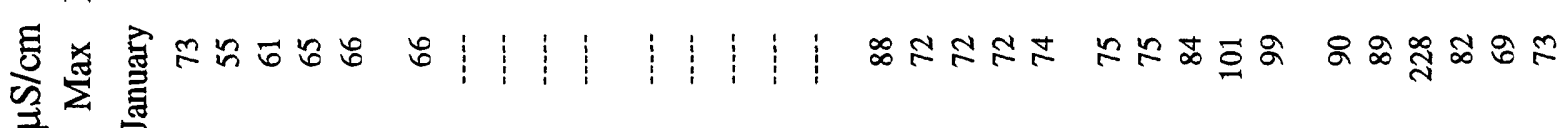

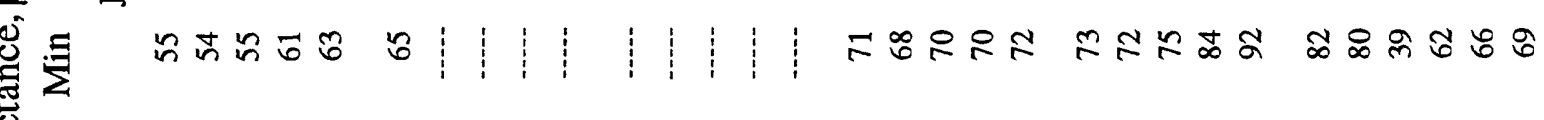
| 跑| 声 氶

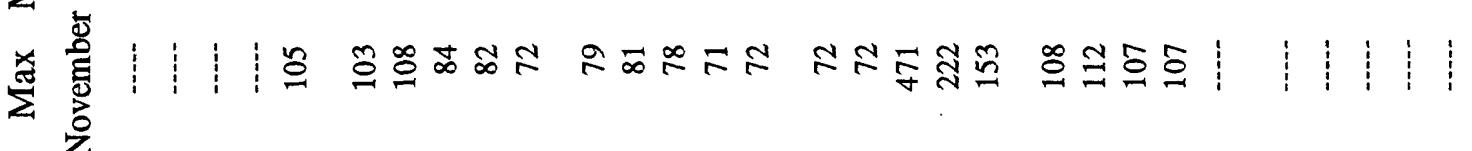
吉 |

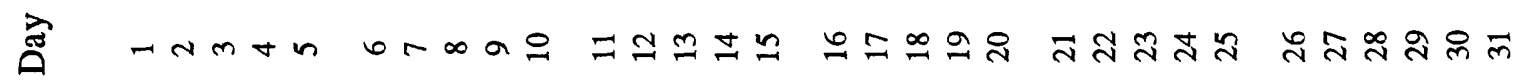




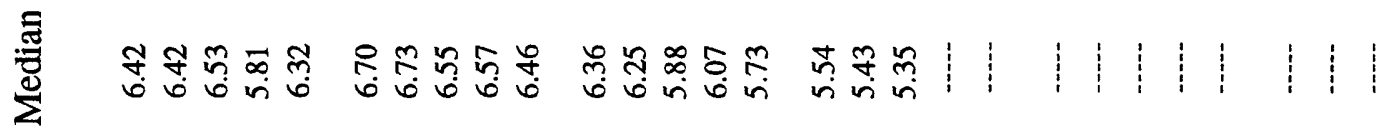

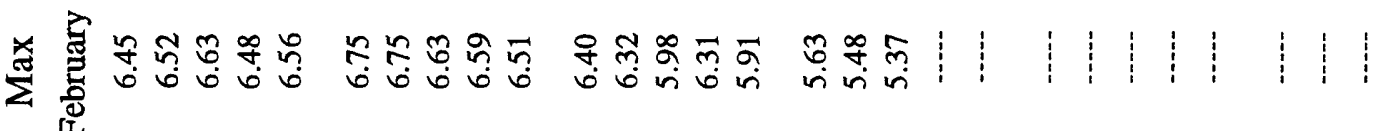

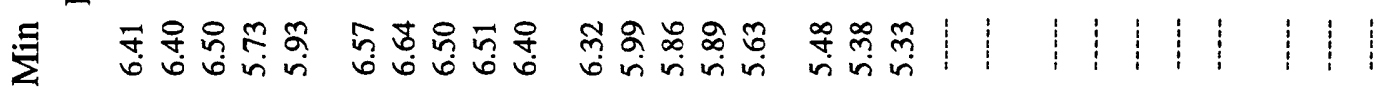

.

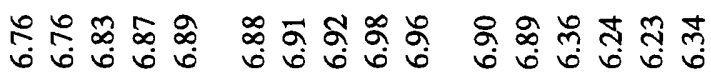

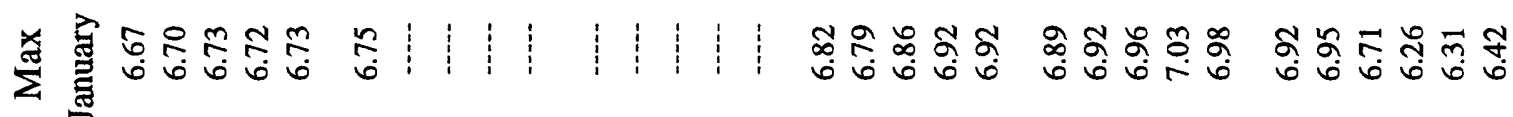

| |

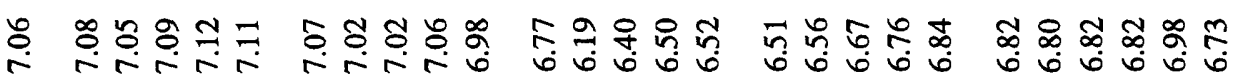

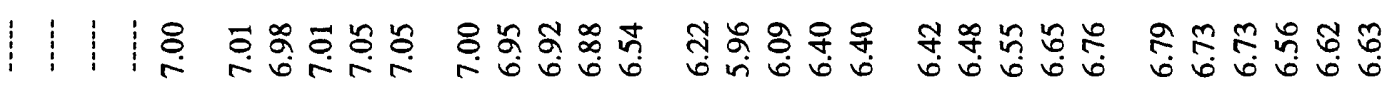

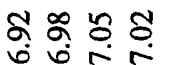

\section{$\pi=\frac{1}{4}$}

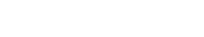

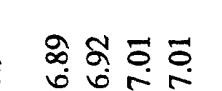

อิ
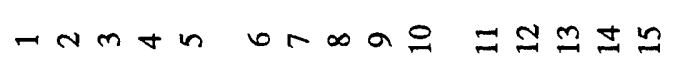

ニㅗำ ํㅜ สำ สำ

ติ

葷 


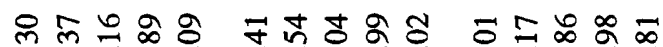

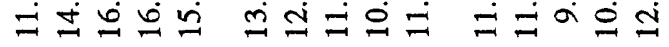

요뭔

远 害

$\sum$

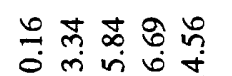

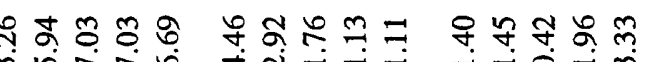

ำษ ชัต

nू̆

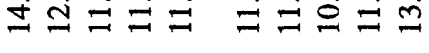

กั สั

웅중ㅇㅇㅇ

ลे

โ유유

$\ddot{m} \dot{2}$

도용

\section{$\infty$}

1

$1:$

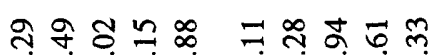

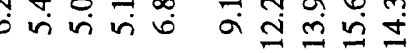

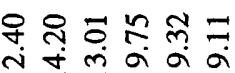

2둧

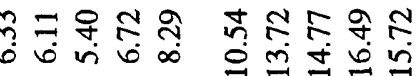

के चี $0 \pm 090$

洨

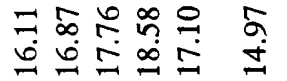

\begin{tabular}{l:l:|l}
$\tilde{a}$ & &
\end{tabular}

$+1:$

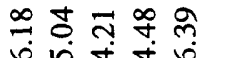

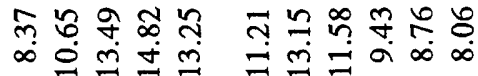

弟焉兽

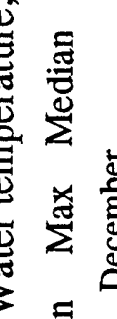

䒠

: : 융ำ

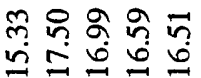

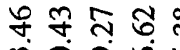

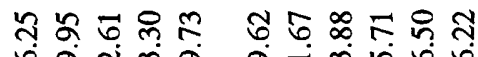

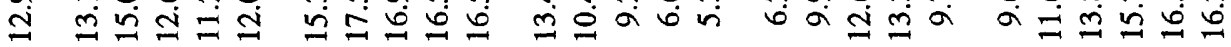
ڤ్

$:$

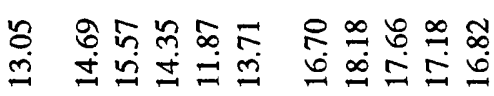

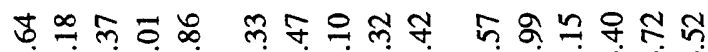

$n=0 \infty$

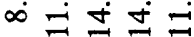

워는

$:: 8$

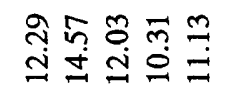

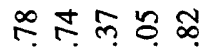

ปสำ

头 ํํㅇㅇㅛ

ิํㅇ휴유

.

6 零

|

ڤூ

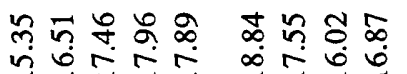

च

$\Sigma$

$z$

$1:$

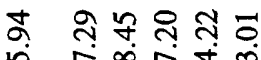

ले

ஸ்士 $\pm 寸$

สำ กิบ ำ

- -

$>$

$1: \infty$

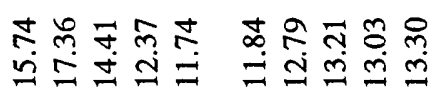

$\sim=\infty \stackrel{\infty}{\infty}$

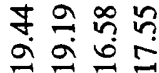

宅

ฉิ

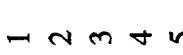

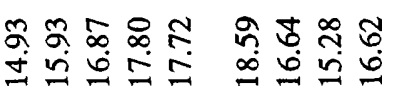

3

نํ.

䒿 


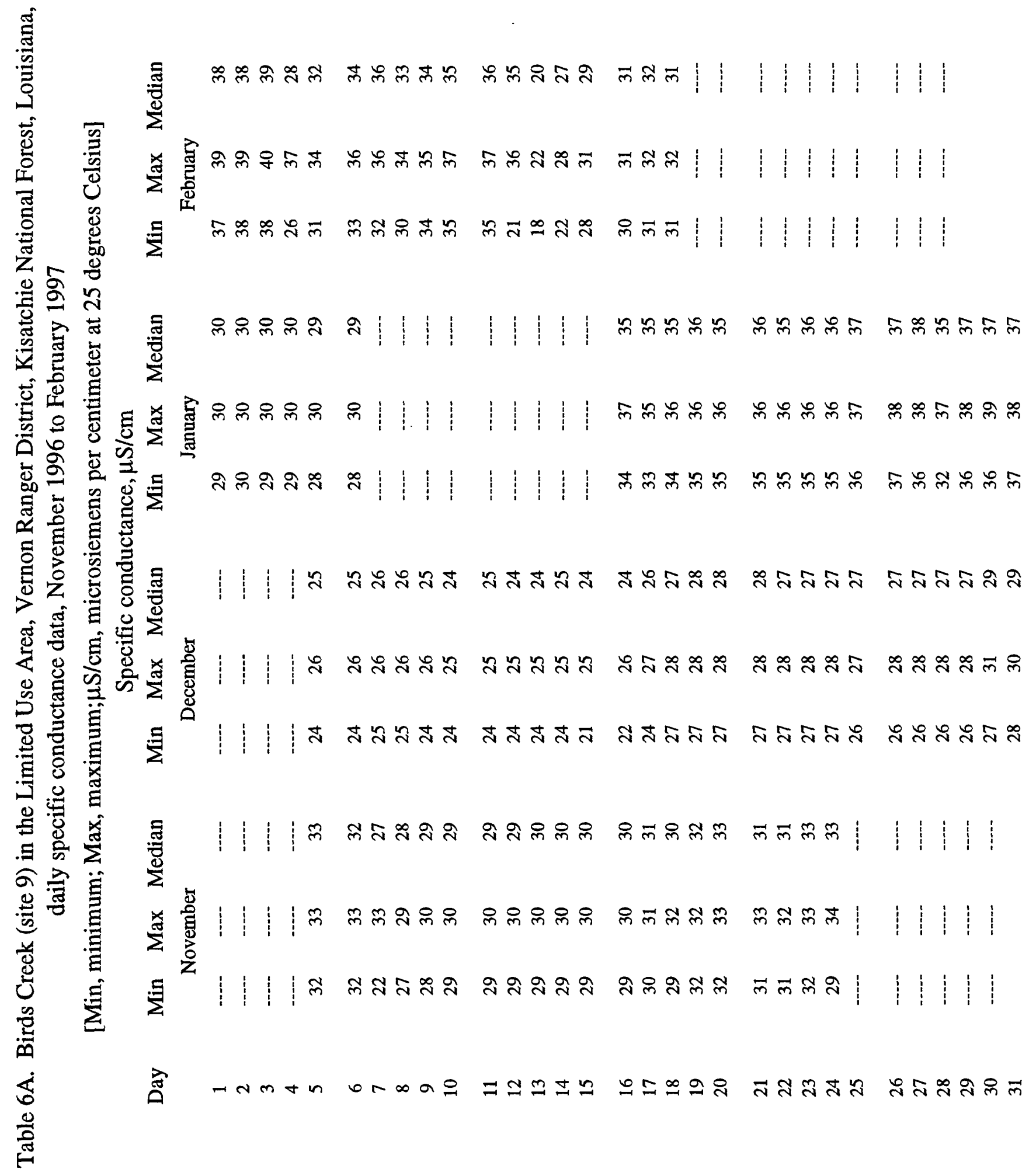




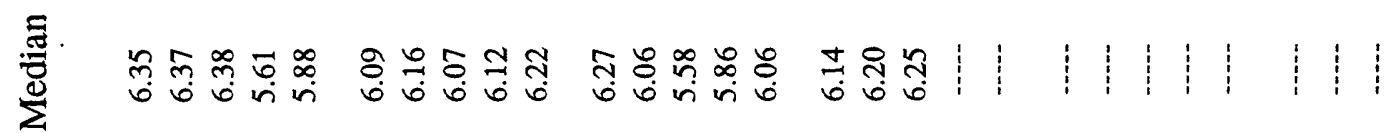

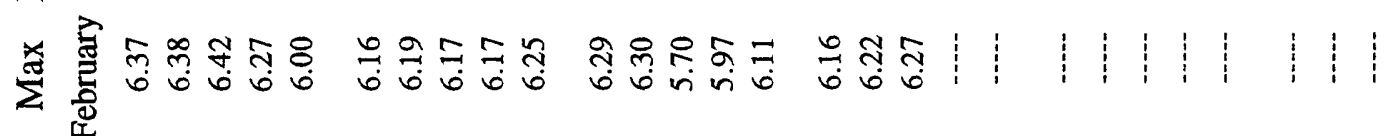

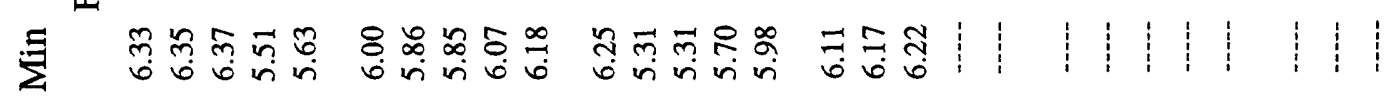

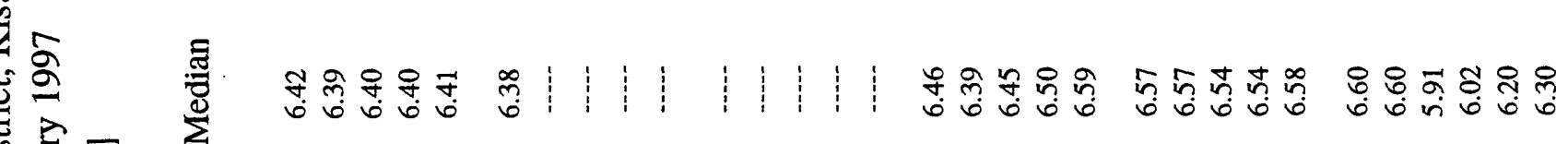

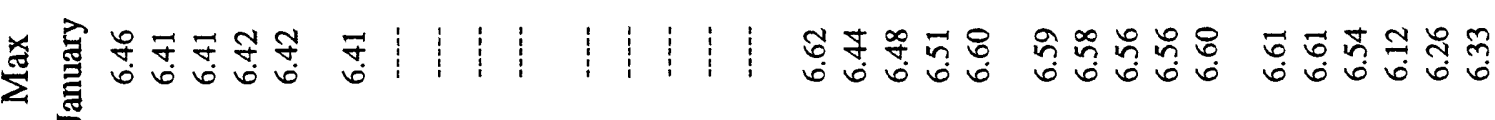

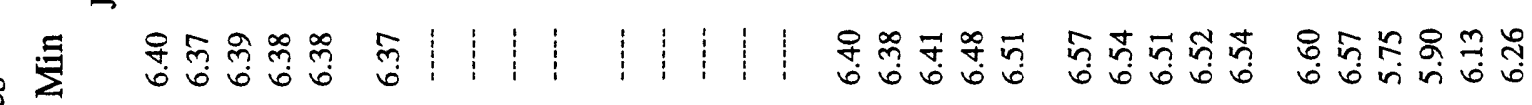

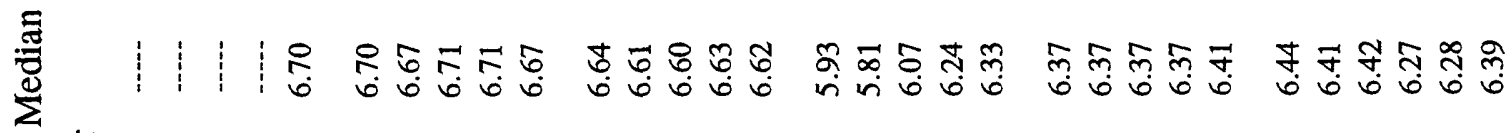
若 声 | |

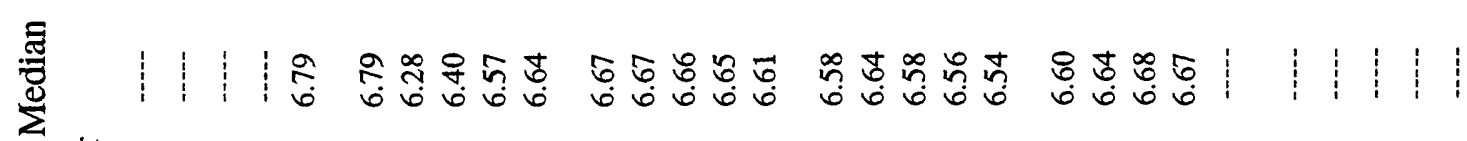
若

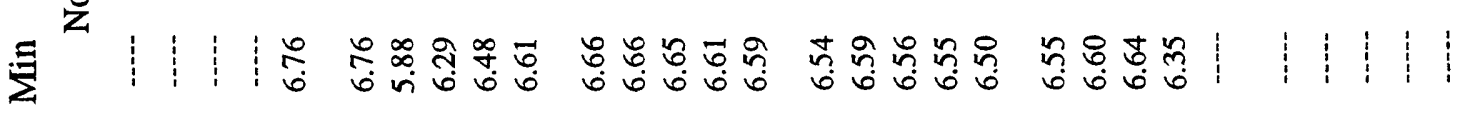

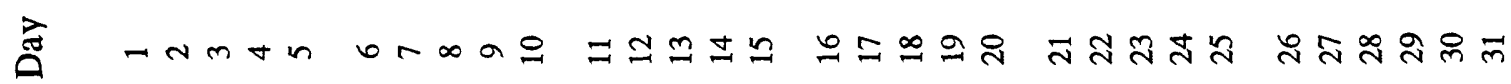




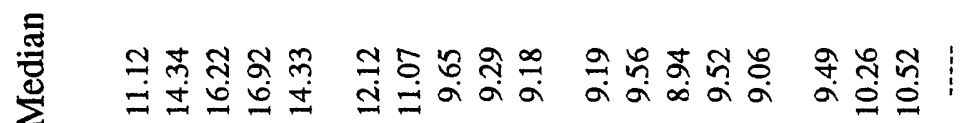

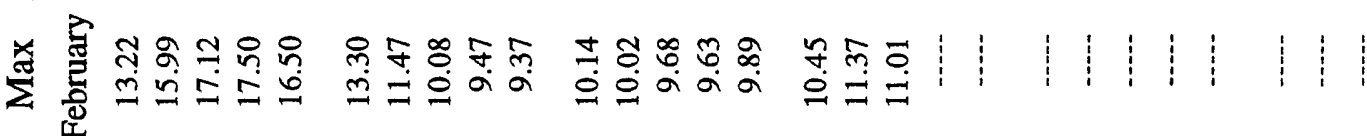

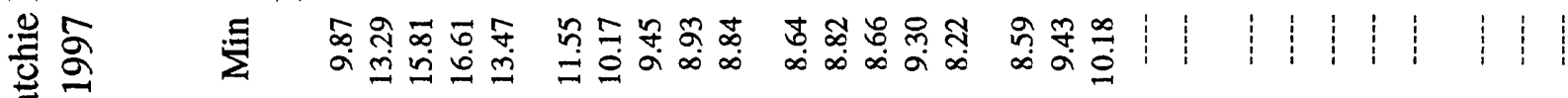

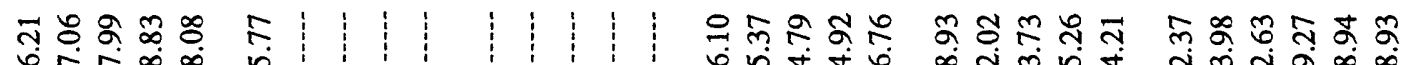
드욤

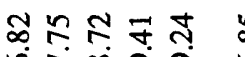

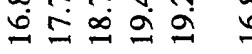

즌ํํำ

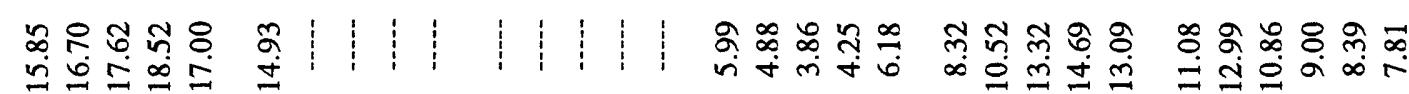

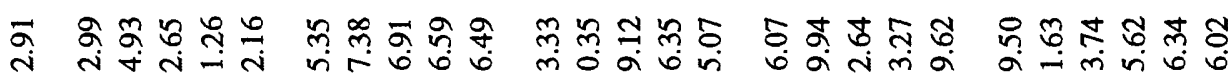
: :

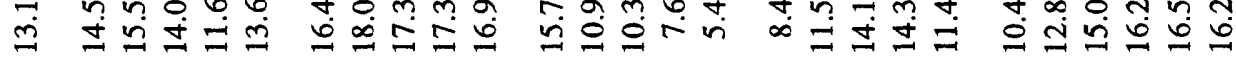

: $\quad$ 守

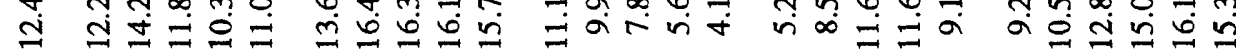




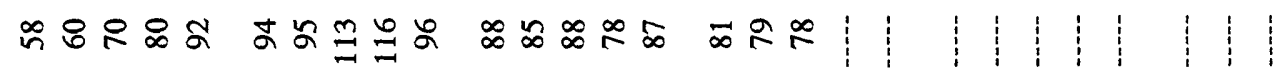

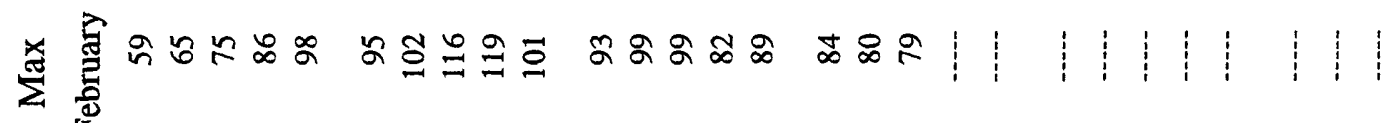

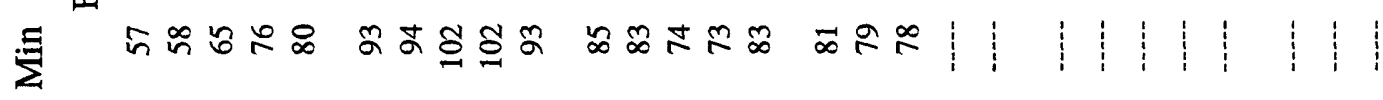

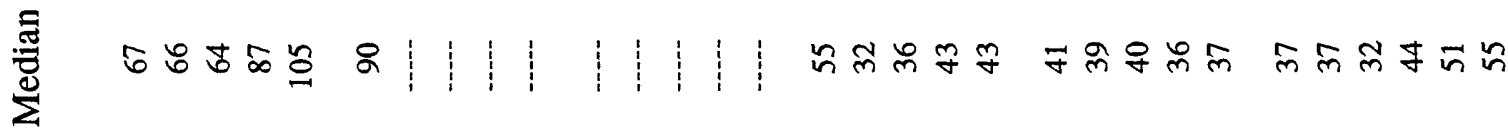

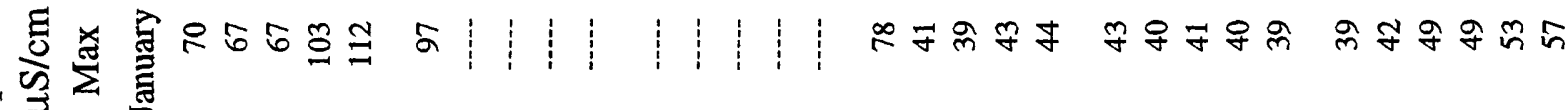

制

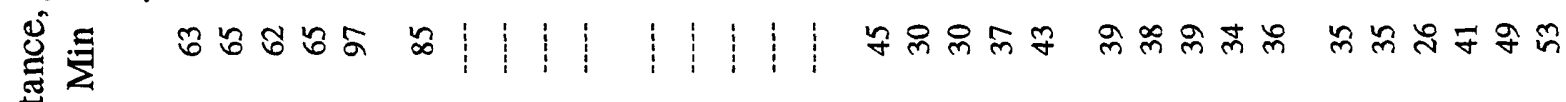

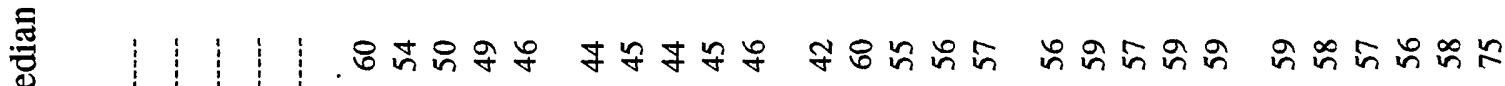

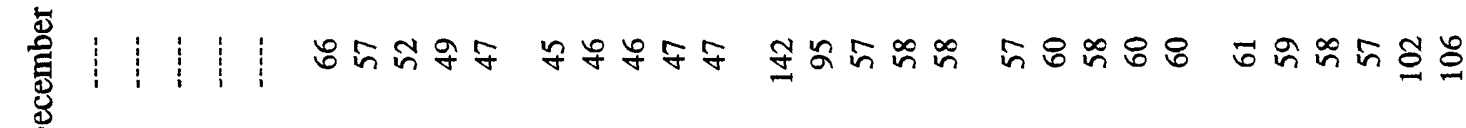
灵

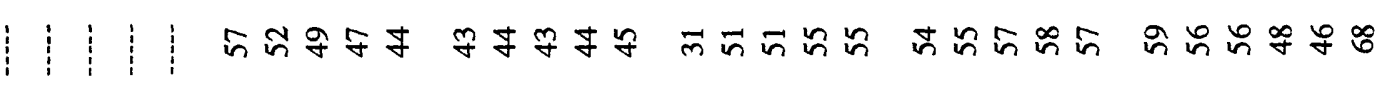

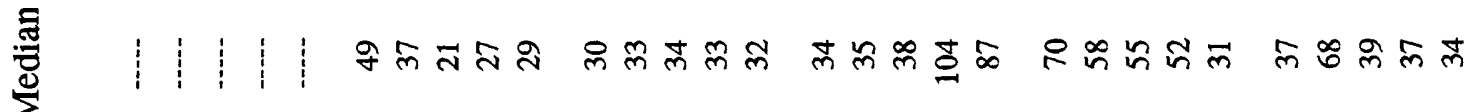




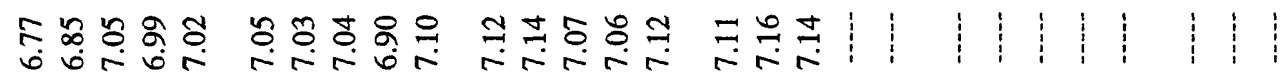

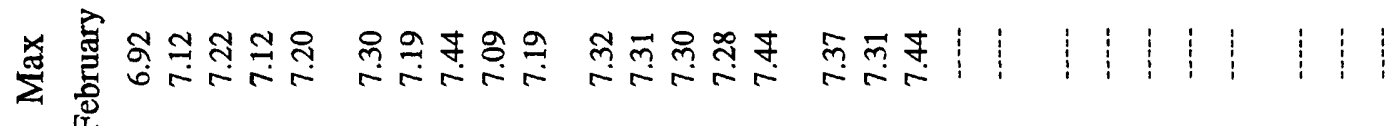

$\Xi$

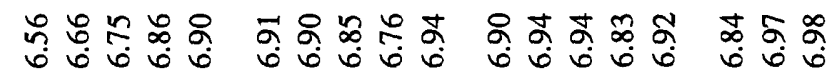

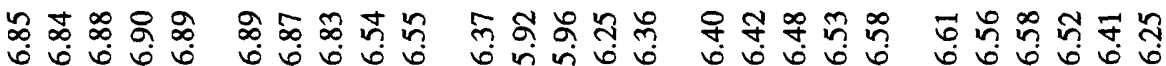

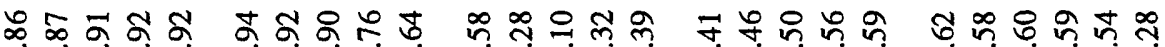

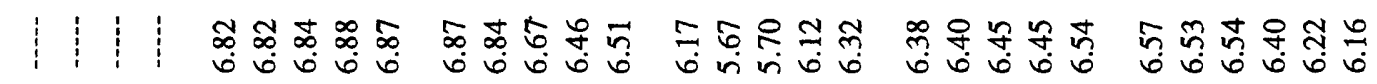

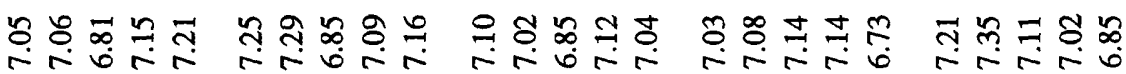
卷 | Z

| 


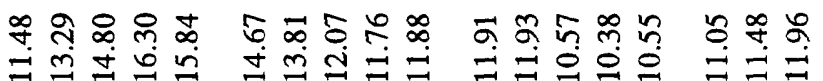

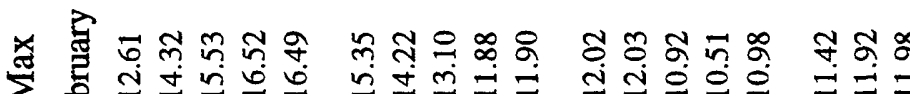

$\sum$

\section{0}

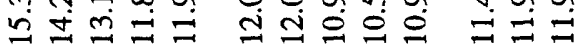

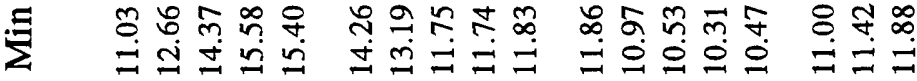

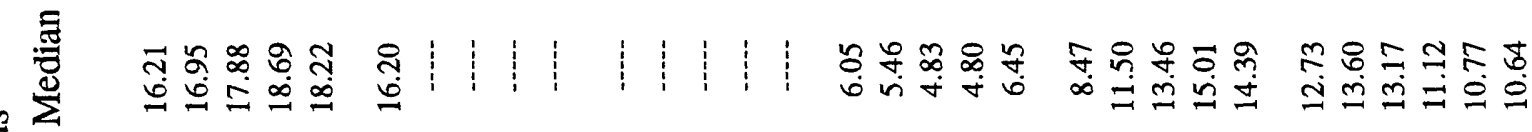

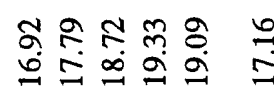

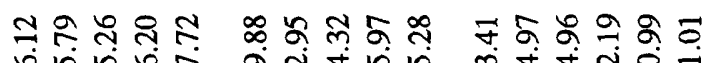

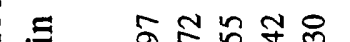

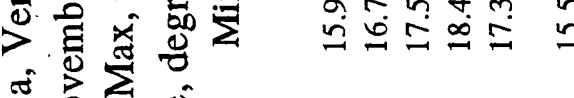

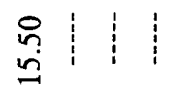

我电舟

=n

过蒠

m

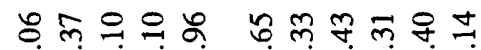

ㅇำ 웅ํำ

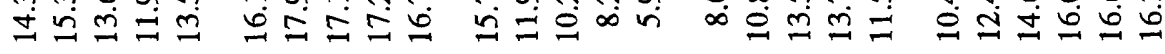

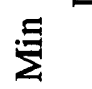

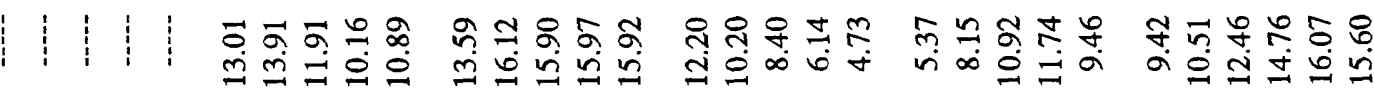

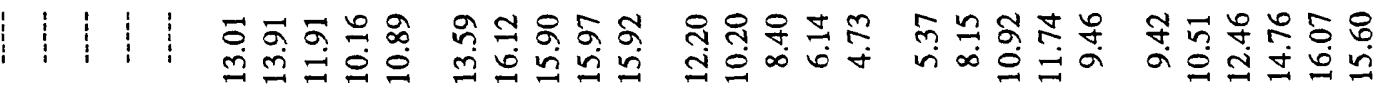

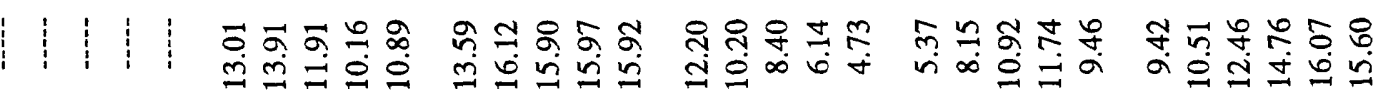

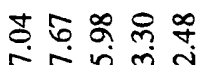

$\approx=8 \circ \circ=0$

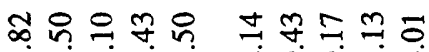

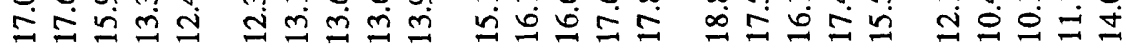

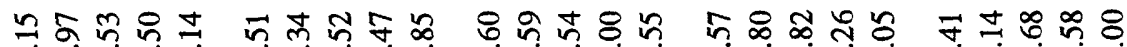
돓ำ

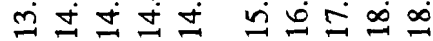

å에

灵

느유용ㅇㅇ

in

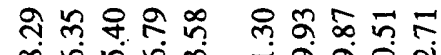

离

도폴

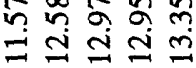
比兰空

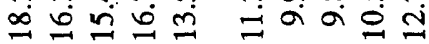

音 -

ن

尊 
章

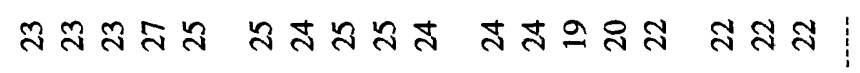

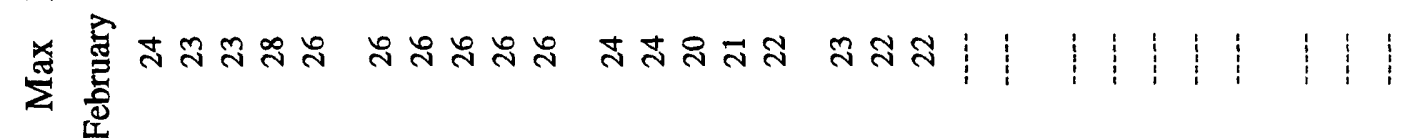

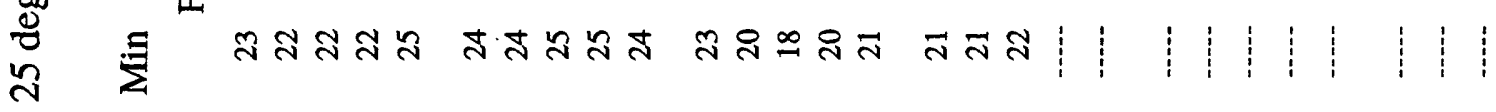

.0.를

\section{}

(1)

ํำง

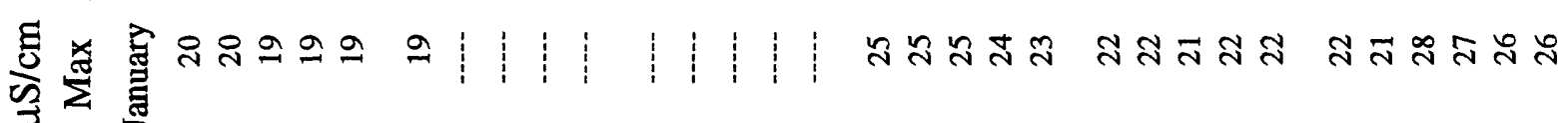

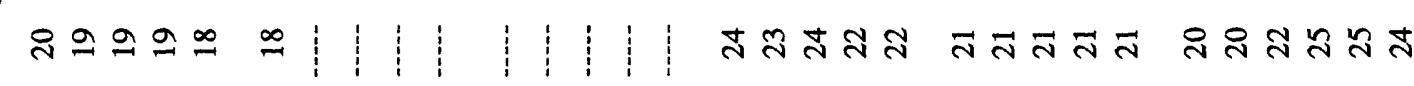

䔅

:

乙 : $\mid$ :

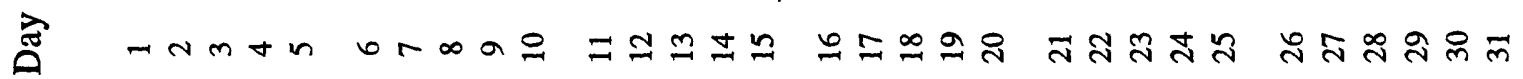




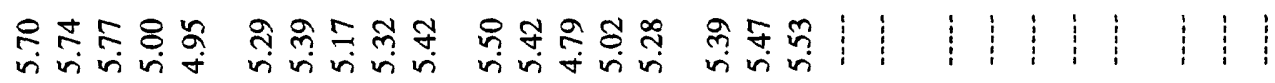

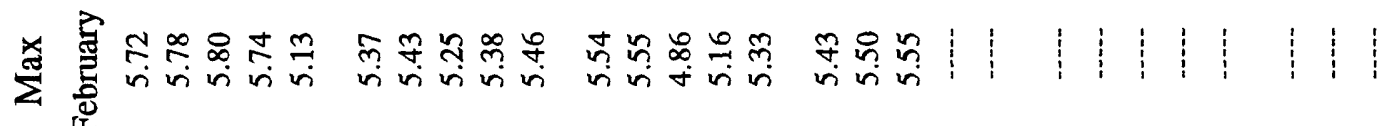

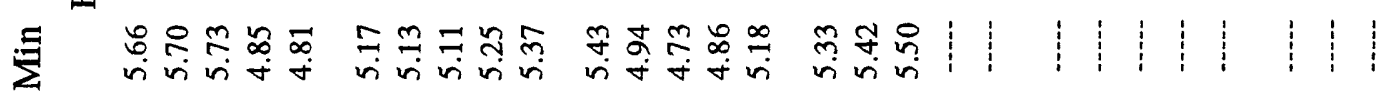

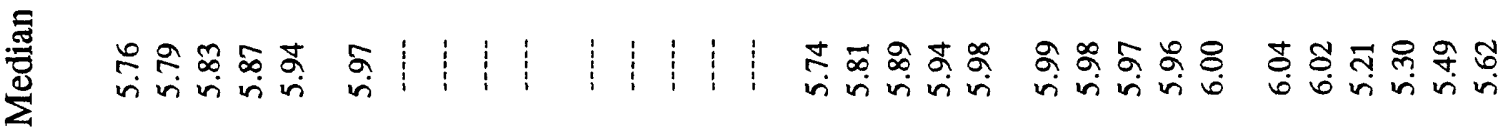

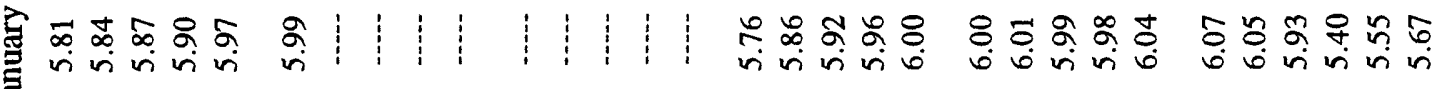

요요 $\infty$

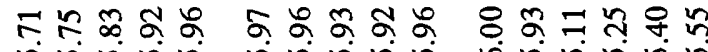

유유요 के 


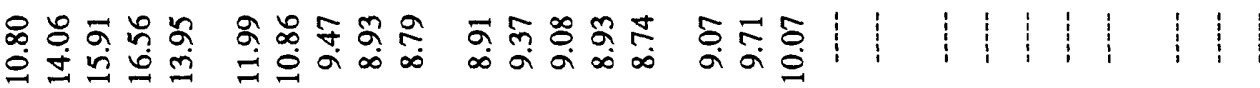

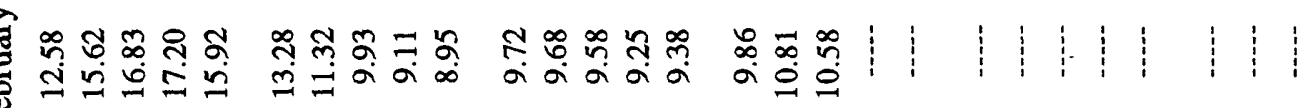

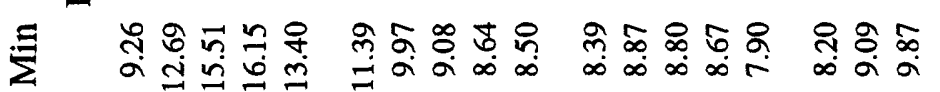

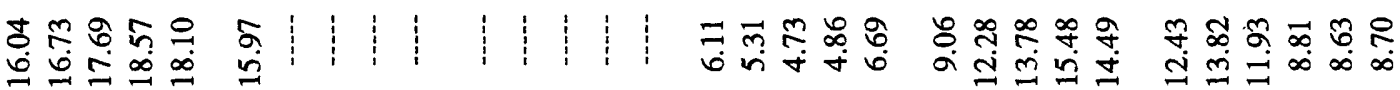

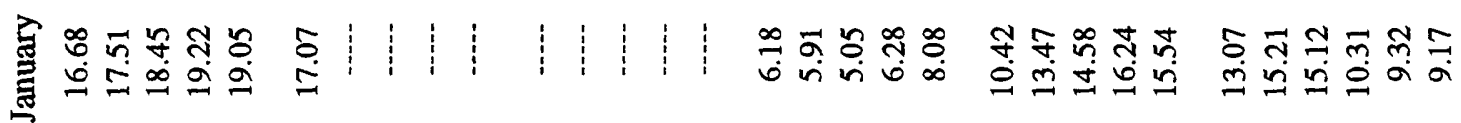
3

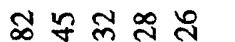

n்

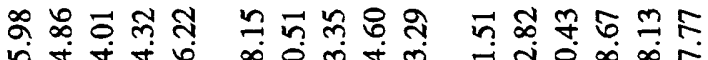

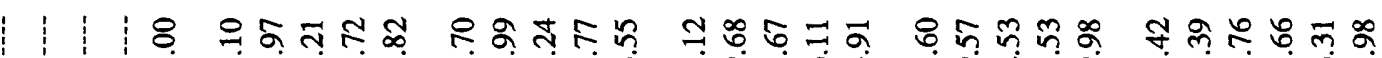

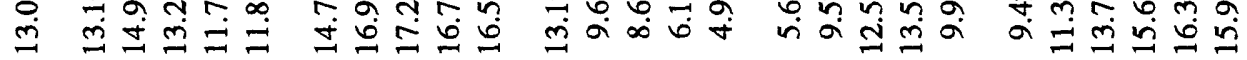

\section{2}

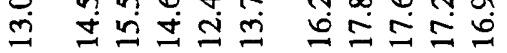

ำกำ ம்

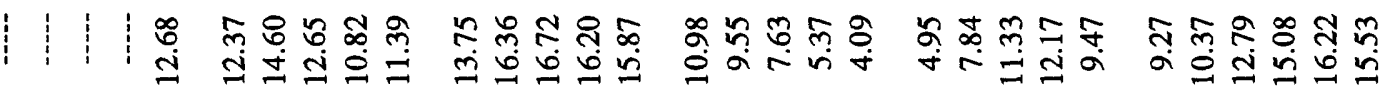

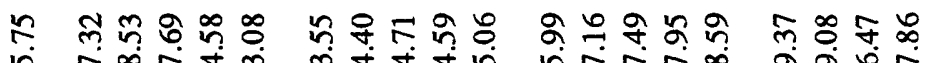

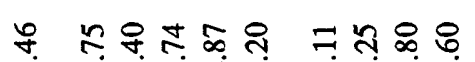

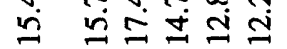

ㅍํ뵤

象

느돋

원두

흠

范

ฮึ

$-n m+n$

$b-\infty a$

으몬

느응

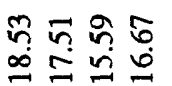

j

完 
恶

俤

吉

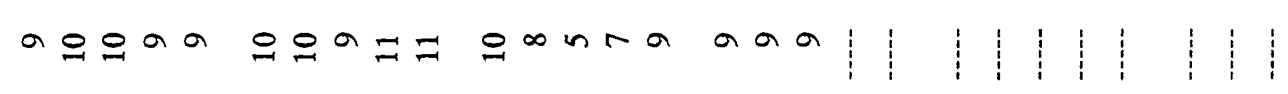

苞

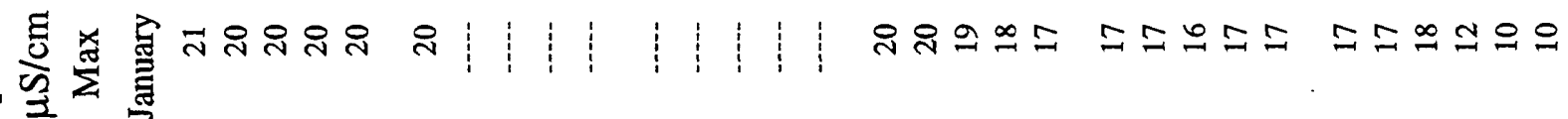

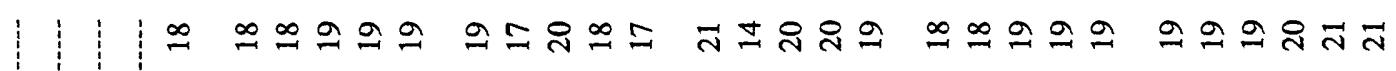
若: 吉 ค

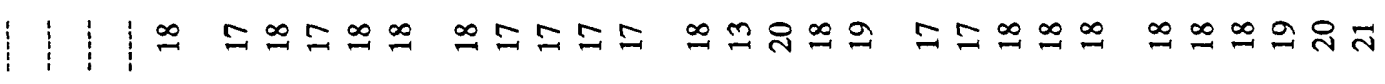

营 龸: $\Xi$

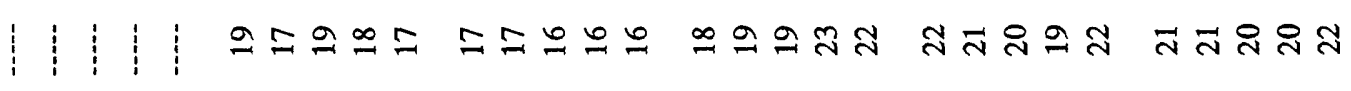




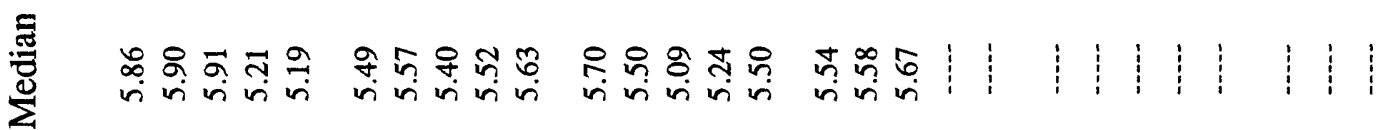

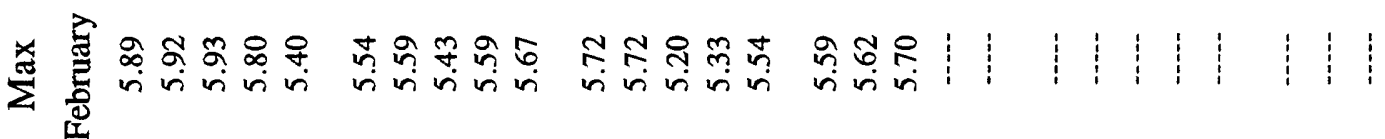

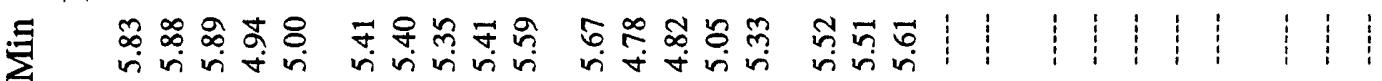

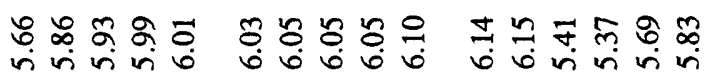
홀

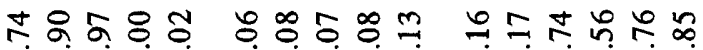

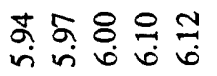

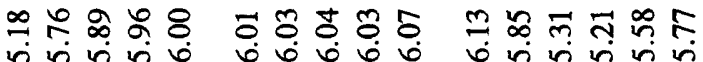

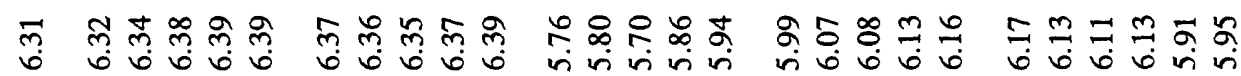
อั

言

|

ఛ

₹ 


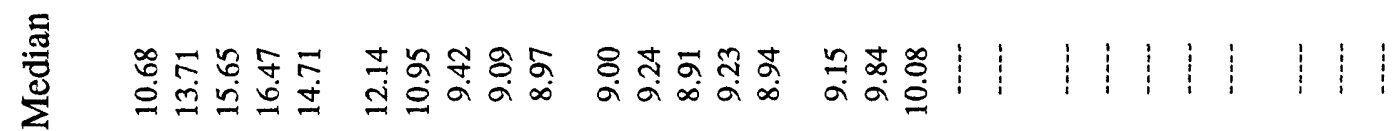

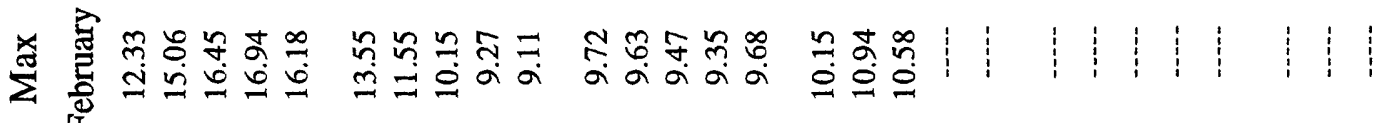

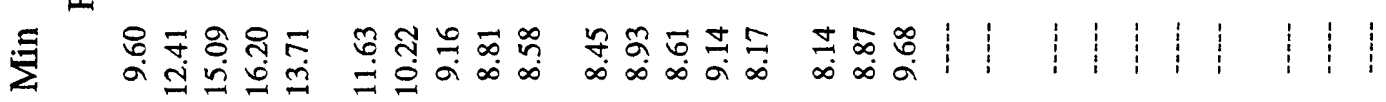

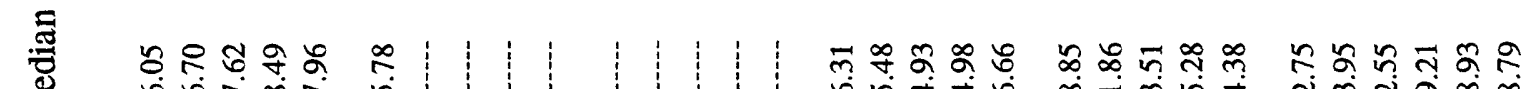

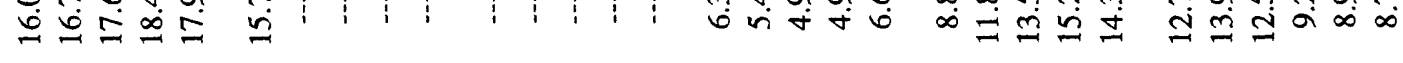
है กิ 는 $\stackrel{\infty}{\infty} \stackrel{\infty}{\infty}$

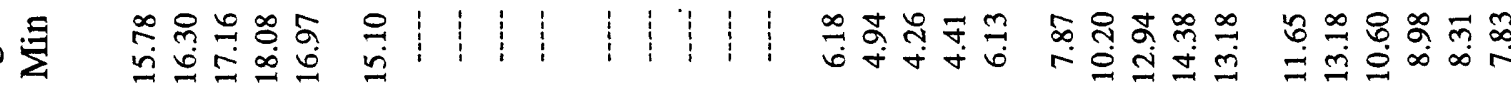

은등 2 市

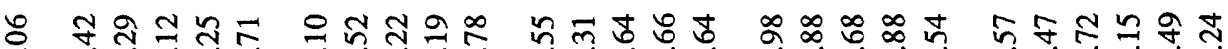

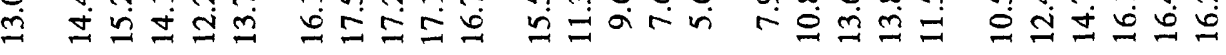

용ㅇㅇㅇㅇ ம்

ปે

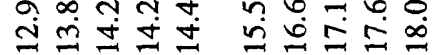

ร

$\infty \pm 0 \div$

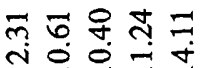

疦

를

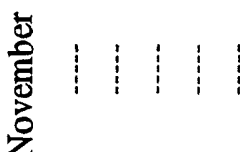

$\Xi$

$1: 1$

फै

홍

焉

ลี

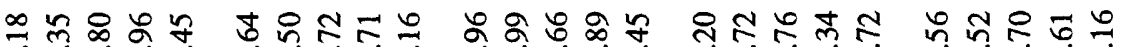
험

윰ำ

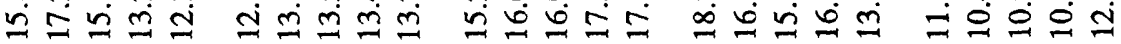

官 
牶

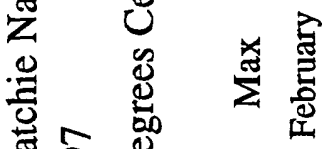

帘

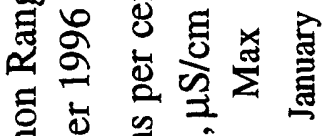

每

逮济

范! :

| $\mid$ |

I

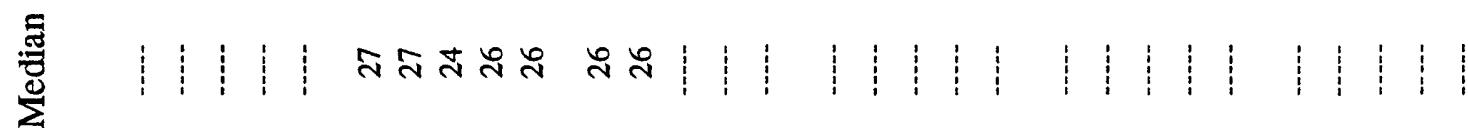




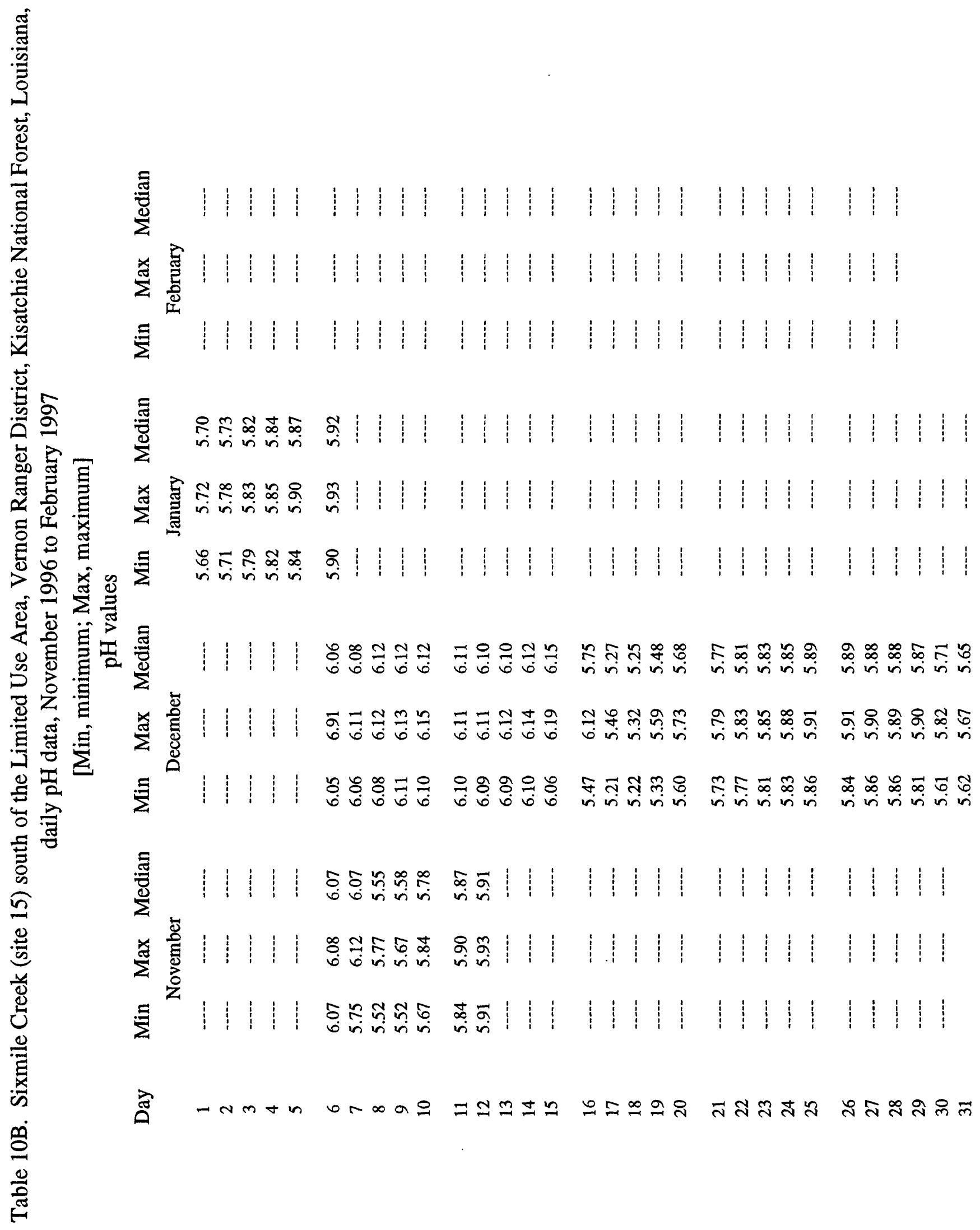


高
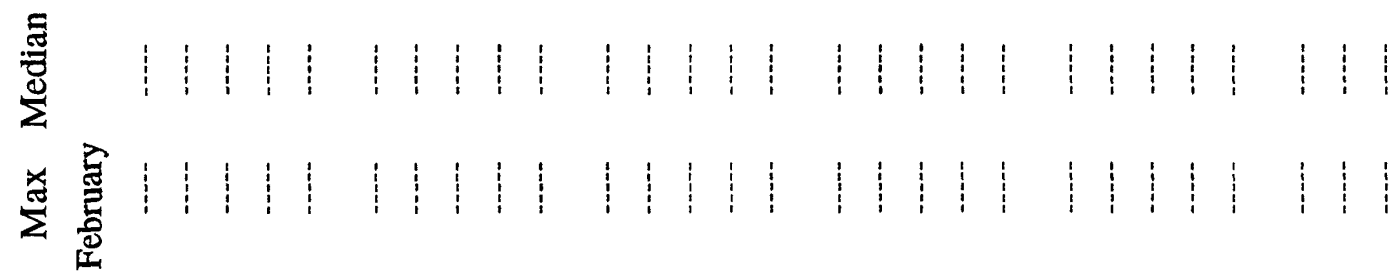

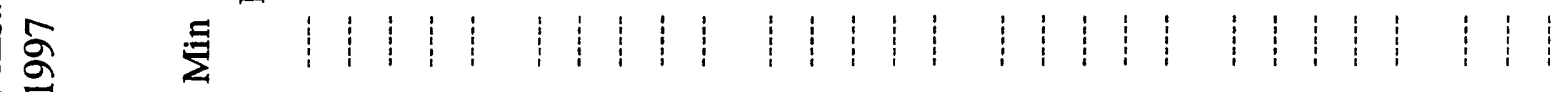

造

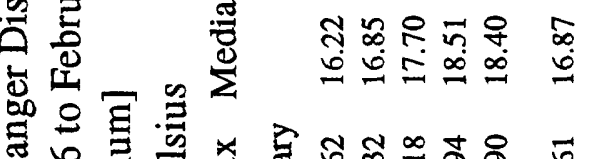

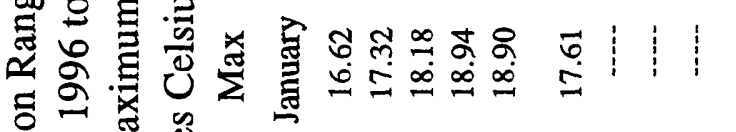

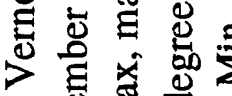

(5)

ङ $2 \sum$ व

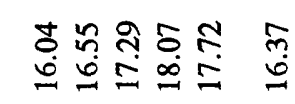

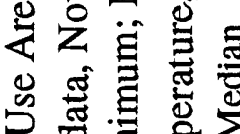

$1: 1:$

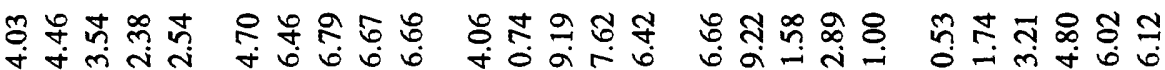

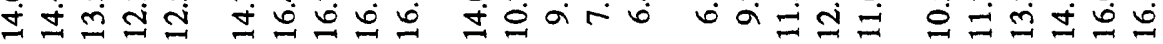

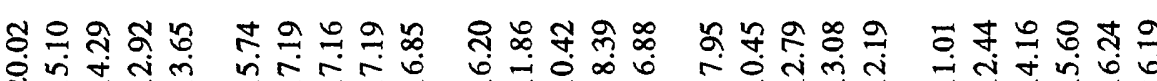
வ்

吾芳

$\stackrel{2}{2} \frac{2}{7}$

苞

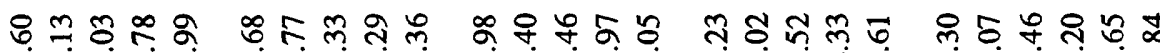
可岛

逮

远

$\equiv$

z

这

尝

is

ర̧⿻上丨

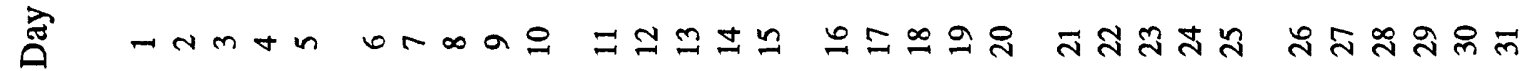

$\frac{0}{\text { है }}$ 
Table 11. Calcium concentrations, in milligrams per liter (mg/L), for daily sampling sites in the Limited Use Area, Vernon Ranger District, Kisatchie National Forest, Louisiana

\begin{tabular}{|c|c|c|c|c|c|c|c|}
\hline $\begin{array}{c}\text { Date } \\
\text { Collected }\end{array}$ & $\begin{array}{c}\text { Whiskey } \\
\text { Chitto, } \\
\text { Site } 7\end{array}$ & $\begin{array}{c}\text { Birds } \\
\text { Creek, } \\
\text { Site } 9 \\
\end{array}$ & $\begin{array}{l}\text { Whiskey } \\
\text { Chitto, } \\
\text { Site } 8\end{array}$ & $\begin{array}{c}\text { West Fork } \\
\text { Creek, } \\
\text { Site } 11\end{array}$ & $\begin{array}{c}\text { East Fork } \\
\text { Creek, } \\
\text { Site } 13\end{array}$ & $\begin{array}{l}\text { Sixmile } \\
\text { Creek, } \\
\text { Site } 15\end{array}$ & $\begin{array}{c}\text { Rainfall, } \\
\text { inches }\end{array}$ \\
\hline $10 / 21 / 96$ & NA & NA & NA & NA & NA & NA & 0.00 \\
\hline $10 / 22 / 96$ & 8.7 & 2.4 & 6.8 & 0.8 & 1.0 & 1.0 & 0.87 \\
\hline $10 / 23 / 96$ & 10.6 & 2.1 & 6.1 & 0.8 & 1.0 & 1.0 & 0.00 \\
\hline $10 / 24 / 96$ & 15.2 & 2.2 & 7.1 & 0.8 & 0.8 & 1.0 & 1.69 \\
\hline $10 / 25 / 96$ & NA & 1.8 & 8.1 & 0.9 & 0.9 & 1.0 & 1.03 \\
\hline $10 / 26 / 96$ & NA & NA & NA & NA & NA & NA & 0.21 \\
\hline $10 / 27 / 96$ & NA & NA & NA & NA & NA & NA & 0.01 \\
\hline $10 / 28 / 96$ & 10.4 & 2.7 & 6.6 & 1.2 & 1.4 & 1.3 & 0.00 \\
\hline $10 / 29 / 96$ & 11.9 & 3.0 & 7.2 & 1.1 & 1.2 & 1.4 & 0.00 \\
\hline $10 / 30 / 96$ & 13.2 & 3.2 & NA & 1.1 & 1.2 & 1.3 & 0.21 \\
\hline $10 / 31 / 96$ & 12.8 & 3.1 & 8.2 & 1.1 & 1.2 & 1.3 & 0.00 \\
\hline $11 / 01 / 96$ & 12.0 & 3.3 & 8.0 & 1.0 & 1.2 & 1.2 & 0.00 \\
\hline $11 / 02 / 96$ & NA & NA & NA & NA & NA & NA & 0.00 \\
\hline $11 / 03 / 96$ & NA & NA & NA & NA & NA & NA & 0.00 \\
\hline $11 / 04 / 96$ & 12.8 & 3.2 & 8.9 & 0.9 & 1.1 & 1.3 & 0.00 \\
\hline $11 / 05 / 96$ & 12.3 & 3.2 & 8.6 & 0.9 & 1.1 & 1.2 & 0.00 \\
\hline $11 / 06 / 96$ & 12.3 & 3.0 & 7.8 & 0.9 & 1.1 & 1.3 & 0.01 \\
\hline $11 / 07 / 96$ & 10.8 & 2.6 & 7.2 & 0.9 & 0.9 & 1.2 & 0.30 \\
\hline $11 / 08 / 96$ & 6.8 & 2.1 & 3.6 & 1.2 & 1.3 & 1.4 & 0.00 \\
\hline $11 / 09 / 96$ & NA & NA & NA & NA & NA & NA & 0.00 \\
\hline $11 / 10 / 96$ & NA & NA & NA & NA & NA & NA & 0.00 \\
\hline $11 / 11 / 96$ & 10.3 & 2.4 & 5.4 & 0.9 & 1.1 & 1.4 & 0.00 \\
\hline $11 / 12 / 96$ & 11.9 & 2.5 & 6.3 & 0.8 & 1.1 & 1.2 & 0.00 \\
\hline $11 / 13 / 96$ & 11.5 & 2.4 & 6.9 & 0.8 & 1.0 & 1.3 & 0.00 \\
\hline $11 / 14 / 96$ & 10.5 & 2.4 & 0.8 & 7.2 & 1.0 & 1.2 & 0.00 \\
\hline $11 / 15 / 96$ & 9.8 & 2.4 & 6.5 & 0.8 & 1.0 & 1.1 & 0.00 \\
\hline $11 / 16 / 96$ & NA & NA & NA & NA & NA & NA & 0.06 \\
\hline $11 / 17 / 96$ & NA & NA & NA & NA & NA & NA & 0.25 \\
\hline $11 / 18 / 96$ & NA & 2.3 & 7.8 & 0.9 & 1.0 & 0.9 & $\mathrm{~T}$ \\
\hline $11 / 19 / 96$ & 20.2 & 2.5 & 23.4 & 0.9 & 1.7 & 1.1 & $\mathrm{~T}$ \\
\hline $11 / 20 / 96$ & 17.3 & 2.5 & 10.3 & 1.0 & 1.3 & 1.2 & 0 \\
\hline $11 / 21 / 96$ & 13.5 & 2.5 & 10.8 & 1.0 & 1.3 & 1.3 & $\mathrm{~T}$ \\
\hline $11 / 22 / 96$ & 12.7 & 2.5 & 8.4 & 1.0 & 1.2 & 1.2 & 0 \\
\hline $11 / 23 / 96$ & NA & NA & NA & NA & NA & NA & 0 \\
\hline $11 / 24 / 96$ & NA & NA & NA & NA & $\mathrm{NA}$ & NA & 0.47 \\
\hline $11 / 25 / 96$ & 7.2 & 2.4 & 4.5 & 1.3 & 1.3 & 1.5 & 0.03 \\
\hline
\end{tabular}

NA - not available

$\mathrm{T}$ - trace amounts of rainfall 
Table 12. Magnesium concentrations, in milligrams per liter ( $\mathrm{mg} / \mathrm{L})$, for daily sampling sites in the Limited Use Area, Vernon Ranger District, Kisatchie National Forest, Louisiana

\begin{tabular}{|c|c|c|c|c|c|c|c|}
\hline $\begin{array}{c}\text { Date } \\
\text { Collected }\end{array}$ & $\begin{array}{c}\text { Whiskey } \\
\text { Chitto, } \\
\text { Site } 7 \\
\end{array}$ & $\begin{array}{c}\text { Birds } \\
\text { Creek, } \\
\text { Site } 9 \\
\end{array}$ & $\begin{array}{c}\text { Whiskey } \\
\text { Chitto, } \\
\text { Site } 8\end{array}$ & $\begin{array}{c}\text { West Fork } \\
\text { Creek, } \\
\text { Site } 11 \\
\end{array}$ & $\begin{array}{c}\text { East Fork } \\
\text { Creek, } \\
\text { Site } 13 \\
\end{array}$ & $\begin{array}{l}\text { Sixmile } \\
\text { Creek, } \\
\text { Site } 15 \\
\end{array}$ & $\begin{array}{c}\text { Rainfall, } \\
\text { inches }\end{array}$ \\
\hline $10 / 21 / 96$ & $\overline{\mathrm{NA}}$ & NA & $\overline{\mathrm{NA}}$ & NA & NA & $\overline{\mathrm{NA}}$ & $\overline{\mathrm{NA}}$ \\
\hline $10 / 22 / 96$ & 0.9 & 0.7 & 0.9 & 0.5 & 0.5 & 0.5 & 0.87 \\
\hline $10 / 23 / 96$ & 1.1 & 0.7 & 0.9 & 0.5 & 0.5 & 0.5 & 0.00 \\
\hline $10 / 24 / 96$ & 1.3 & 0.7 & 1.0 & 0.5 & 0.4 & 0.6 & 1.69 \\
\hline $10 / 25 / 96$ & NA & 0.5 & 0.9 & 0.5 & 0.5 & 0.5 & 1.03 \\
\hline $10 / 26 / 96$ & NA & NA & NA & NA & NA & NA & 0.21 \\
\hline $10 / 27 / 96$ & NA & NA & NA & NA & NA & NA & 0.01 \\
\hline $10 / 28 / 96$ & 1.0 & 0.7 & 0.8 & 0.6 & 0.6 & 0.7 & 0.00 \\
\hline $10 / 29 / 96$ & 1.2 & 0.8 & 1.0 & 0.6 & 0.6 & 0.7 & 0.00 \\
\hline $10 / 30 / 96$ & 1.2 & 0.9 & NA & 0.6 & 0.6 & 0.7 & 0.21 \\
\hline $10 / 31 / 96$ & 1.2 & 1.0 & 1.1 & 0.7 & 0.6 & 0.7 & 0.00 \\
\hline $11 / 01 / 96$ & 1.2 & 1.0 & 1.1 & 0.6 & 0.6 & 0.7 & 0.00 \\
\hline $11 / 02 / 96$ & NA & NA & NA & NA & NA & NA & 0.00 \\
\hline $11 / 03 / 96$ & NA & NA & NA & NA & NA & NA & 0.00 \\
\hline $11 / 04 / 96$ & 1.3 & 1.0 & 1.2 & 0.6 & 0.6 & 0.7 & 0.00 \\
\hline $11 / 05 / 96$ & 1.3 & 0.9 & 1.1 & 0.5 & 0.5 & 0.7 & 0.00 \\
\hline $11 / 06 / 96$ & 1.2 & 0.9 & 1.1 & 0.5 & 0.5 & 0.7 & 0.01 \\
\hline $11 / 07 / 96$ & 1.1 & 0.8 & 1.1 & 0.5 & 0.5 & 0.6 & 0.30 \\
\hline $11 / 08 / 96$ & 0.9 & 0.7 & 0.9 & 0.7 & 0.7 & 0.7 & 0.00 \\
\hline $11 / 09 / 96$ & NA & NA & $\mathrm{NA}$ & NA & NA & NA & 0.00 \\
\hline $11 / 10 / 96$ & NA & NA & NA & NA & NA & NA & 0.00 \\
\hline $11 / 11 / 96$ & 1.2 & 0.8 & 1.0 & 0.5 & 0.6 & 0.7 & 0.00 \\
\hline $11 / 12 / 96$ & 1.25 & 0.8 & 1.0 & 0.6 & 0.6 & 0.7 & 0.00 \\
\hline $11 / 13 / 96$ & 1.14 & 0.7 & 1.1 & 0.5 & 0.6 & 0.6 & 0.00 \\
\hline $11 / 14 / 96$ & 1.07 & 0.8 & 1.1 & 0.5 & 0.6 & 1.1 & 0.00 \\
\hline $11 / 15 / 96$ & 1.0 & 0.8 & 1.0 & 0.5 & 0.5 & 0.6 & 0.00 \\
\hline $11 / 16 / 96$ & NA & NA & NA & NA & NA & NA & 0.06 \\
\hline $11 / 17 / 96$ & NA & NA & NA & NA & NA & NA & 0.25 \\
\hline $11 / 18 / 96$ & NA & 0.8 & 1.1 & 0.6 & 0.6 & 0.5 & $\mathrm{~T}$ \\
\hline $11 / 19 / 96$ & 1.2 & 0.8 & 1.4 & 0.5 & 0.7 & 0.6 & $\mathrm{~T}$ \\
\hline $11 / 20 / 96$ & 1.4 & 0.8 & 1.0 & 0.5 & 0.6 & 0.6 & 0 \\
\hline $11 / 21 / 96$ & 1.2 & 0.8 & 1.1 & 0.5 & 0.6 & 0.7 & $\mathrm{~T}$ \\
\hline $11 / 22 / 96$ & 1.2 & 0.9 & 1.0 & 0.5 & 0.6 & 0.6 & 0 \\
\hline $11 / 23 / 96$ & NA & NA & NA & NA & NA & NA & 0 \\
\hline $11 / 24 / 96$ & NA & NA & NA & NA & NA & NA & 0.47 \\
\hline $11 / 25 / 96$ & 1.0 & 0.9 & 0.9 & 0.7 & 0.6 & 0.8 & 0.03 \\
\hline
\end{tabular}

NA - not available

$\mathrm{T}$ - trace amounts of rainfall 
Table 13. Major inorganic ion data for daily sampling sites in the Limited Use Area, Vernon Ranger District, Kisatchie National Forest, Louisiana

[mg/L, milligrams per liter; meq $/ \mathrm{L}$, milliequivalents per liter]

\begin{tabular}{|c|c|c|c|c|c|c|c|c|}
\hline \multicolumn{4}{|c|}{ Site Location: Whiskey Chitto Creek - site 6} & \multicolumn{3}{|c|}{ Date: October 22, 1996} & \multicolumn{2}{|c|}{ Time: $\underline{0900}$} \\
\hline Cations & $\mathrm{mg} / \mathrm{L}$ & $\mathrm{meq} / \mathrm{L}$ & percent & Anions & & $\mathrm{mg} / \mathrm{L}$ & $\mathrm{meq} / \mathrm{L}$ & percent \\
\hline Sodium $\mathrm{Na}$ & 10.0 & 0.435 & 43.53 & Chloride & $\mathrm{Cl}$ & 8.9 & 0.251 & 26.25 \\
\hline Potassium $\mathrm{K}$ & 2.2 & 0.056 & 5.63 & Fluoride & $\mathrm{F}$ & 0.1 & 0.005 & 0.55 \\
\hline Magnesium $\mathrm{Mg}$ & 0.9 & 0.074 & 7.41 & Sulfate & $\mathrm{SO}_{4}$ & 5.8 & 0.121 & 12.62 \\
\hline \multirow[t]{3}{*}{ Calcium $\mathrm{Ca}$} & 8.7 & 0.434 & 43.44 & *Bicarbonate & $\mathrm{HCO}_{3}$ & 35.4 & 0.579 & 60.58 \\
\hline & Totals: & 0.999 & & Carbonate & $\mathrm{CO}_{3}$ & 0.0 & 0.000 & 0.00 \\
\hline & & & & $\begin{array}{l}\text { Lab Alkalinity } \\
\text { * Bicarbonate c }\end{array}$ & from & $\begin{array}{l}\text { Totals: } \\
29.0 \\
\text { alkalinit }\end{array}$ & 0.956 & \\
\hline
\end{tabular}

\begin{tabular}{|c|c|c|c|c|c|c|c|c|}
\hline \multicolumn{4}{|c|}{ Site Location: Birds Creek - site 9} & \multicolumn{3}{|c|}{ Date: October 22,1996 } & \multicolumn{2}{|c|}{ Time: $\underline{0900}$} \\
\hline Cations & $\mathrm{mg} / \mathrm{L}$ & $\mathrm{meq} / \mathrm{L}$ & percent & Anions & & $\mathrm{mg} / \mathrm{L}$ & meq $/ \mathrm{L}$ & percen \\
\hline Sodium $\mathrm{Na}$ & 2.5 & 0.109 & 34.33 & Chloride & $\mathrm{Cl}$ & 3.7 & 0.104 & 32.57 \\
\hline Potassium $\mathrm{K}$ & 1.2 & 0.031 & 9.69 & Fluoride & $\mathrm{F}$ & 0.1 & 0.005 & 1.64 \\
\hline Magnesium $\mathrm{Mg}$ & 0.7 & 0.058 & 18.18 & Sulfate & $\mathrm{SO}_{4}$ & 0.8 & 0.017 & 5.33 \\
\hline \multirow[t]{5}{*}{ Calcium $\mathrm{Ca}$} & 2.4 & 0.120 & 37.81 & *Bicarbonate & $\mathrm{HCO}_{3}$ & 11.8 & 0.194 & 60.47 \\
\hline & Totals: & 0.317 & & Carbonate & $\mathrm{CO}_{3}$ & 0.0 & 0.000 & 0.00 \\
\hline & & & & & & Totals: & 0.321 & \\
\hline & & & & Lab Alkalinity & & 9.7 & & \\
\hline & & & & * Bicarbonate cc & ted from & lkalinit & & \\
\hline
\end{tabular}

\begin{tabular}{|c|c|c|c|c|c|c|c|c|}
\hline \multicolumn{4}{|c|}{ Site Location: Whiskey Chitto Creek - site 7} & \multicolumn{3}{|c|}{ Date: October 22,1996} & \multicolumn{2}{|c|}{ Time: $\underline{0900}$} \\
\hline Cations & $\mathrm{mg} / \mathrm{L}$ & $\mathrm{meq} / \mathrm{L}$ & percent & Anions & & $\mathrm{mg} / \mathrm{L}$ & $\mathrm{meq} / \mathrm{L}$ & percent \\
\hline Sodium $\mathrm{Na}$ & 8.6 & 0.374 & 44.88 & Chloride & $\mathrm{Cl}$ & 7.5 & 0.212 & 26.50 \\
\hline Potassium $\mathrm{K}$ & 1.8 & 0.046 & 5.52 & Fluoride & $\mathrm{F}$ & 0.1 & 0.005 & 0.66 \\
\hline Magnesium $\mathrm{Mg}$ & 0.9 & 0.074 & 8.88 & Sulfate & $\mathrm{SO}_{4}$ & 4.9 & 0.102 & 12.78 \\
\hline Calcium $\mathrm{Ca}$ & 6.8 & 0.339 & 40.71 & *Bicarbonate & $\mathrm{HCO}_{3}$ & 29.3 & 0.480 & 60.06 \\
\hline & Totals: & 0.833 & & Carbonate & $\mathrm{CO}_{3}$ & 0.0 & 0.000 & 0.00 \\
\hline & & & & $\begin{array}{l}\text { Lab Alkalinity } \\
* \text { Bicarbonate }\end{array}$ & fro & $\begin{array}{r}\text { Cotals: } \\
24.0\end{array}$ & 0.798 & \\
\hline
\end{tabular}

\begin{tabular}{|c|c|c|c|c|c|c|c|c|}
\hline \multicolumn{4}{|c|}{ Site Location: West Fork of Sixmile Creek - site 11} & \multicolumn{3}{|c|}{ Date: October 22, 1996} & \multicolumn{2}{|c|}{ Time: $\underline{0900}$} \\
\hline Cations & $\mathrm{mg} / \mathrm{L}$ & $\mathrm{meq} / \mathrm{L}$ & percent & Anions & & $\mathrm{mg} / \mathrm{L}$ & $\mathrm{meq} / \mathrm{L}$ & percent \\
\hline Sodium $\mathrm{Na}$ & 2.2 & 0.096 & 47.30 & Chloride & $\mathrm{Cl}$ & 3.0 & 0.085 & 40.76 \\
\hline Potassium $\mathrm{K}$ & 1.0 & 0.026 & 12.64 & Fluoride & F & 0.1 & 0.005 & 2.54 \\
\hline Magnesium $\mathrm{Mg}$ & 0.5 & 0.041 & 20.33 & Sulfate & $\mathrm{SO}_{4}$ & 0.3 & 0.006 & 2.81 \\
\hline \multirow[t]{3}{*}{ Calcium } & 0.8 & 0.040 & 19.73 & *Bicarbonate & $\mathrm{HCO}_{3}$ & 6.8 & 0.112 & 53.89 \\
\hline & Totals: & 0.202 & & Carbonate & $\mathrm{CO}_{3}$ & 0.0 & 0.000 & 0.00 \\
\hline & & & & $\begin{array}{l}\text { Lab Alkalinity } \\
\text { * Bicarbonate } \mathrm{co}\end{array}$ & fron & $\begin{array}{c}\text { Totals: } \\
5.6 \\
\text { lkalinit }\end{array}$ & 0.208 & \\
\hline
\end{tabular}


Table 13. Major inorganic ion data for daily sampling sites in the Limited Use Area, Vernon Ranger District, Kisatchie National Forest, Louisiana--Continued

\begin{tabular}{|c|c|c|c|c|c|c|c|c|}
\hline \multicolumn{4}{|c|}{ Site Location: East Fork of Sixmile Creek - site 13} & \multicolumn{3}{|c|}{ Date: October 22, 1996} & \multicolumn{2}{|c|}{ Time: $\underline{0900}$} \\
\hline Cations & $\mathrm{mg} / \mathrm{L}$ & $\mathrm{meq} / \mathrm{L}$ & percent & Anions & & $\mathrm{ng} / \mathrm{L}$ & $\mathrm{meq} / \mathrm{L}$ & percent \\
\hline Sodium $\mathrm{Na}$ & 1.6 & 0.070 & 37.38 & Chloride & $\mathrm{Cl}$ & 3.0 & 0.085 & 40.06 \\
\hline Potassium $\mathrm{K}$ & 1.0 & 0.026 & 13.73 & Fluoride & $\mathrm{F}$ & 0.1 & 0.005 & 2.49 \\
\hline Magnesium $\mathrm{Mg}$ & 0.5 & 0.041 & 22.09 & Sulfate & SO4 & 0.4 & 0.007 & 3.55 \\
\hline \multirow[t]{5}{*}{ Calcium $\mathrm{Ca}$} & 1.0 & 0.050 & 26.80 & *Bicarbonate & $\mathrm{HCO} 3$ & 6.9 & 0.114 & 3.90 \\
\hline & Totals: & 0.186 & & Carbonate & $\mathrm{CO} 3$ & 0.0 & 0.000 & 0.00 \\
\hline & & & & & & tals: & 0.211 & \\
\hline & & & & ab Alkalinity & & 5.7 & & \\
\hline & & & & * Bicarbonate c & ted fron & kalin & & \\
\hline
\end{tabular}

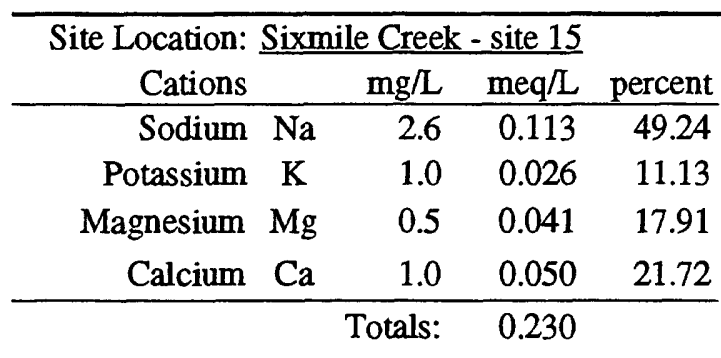

\begin{tabular}{rrrrr}
\multicolumn{2}{c}{ Date: } & October 22,1996 & \multicolumn{2}{c}{ Time: $\underline{0900}$} \\
Anions & & $\mathrm{mg} / \mathrm{L}$ & meq $/ \mathrm{L}$ & percent \\
\hline Chloride & $\mathrm{Cl}$ & 3.3 & 0.093 & 38.45 \\
Fluoride & $\mathrm{F}$ & 0.1 & 0.005 & 2.17 \\
Sulfate & $\mathrm{SO}_{4}$ & 0.4 & 0.008 & 3.27 \\
*Bicarbonate & $\mathrm{HCO}_{3}$ & 8.3 & 0.136 & 56.11 \\
Carbonate & $\mathrm{CO}_{3}$ & 0.0 & 0.000 & 0.00 \\
\hline \multicolumn{4}{c}{ Totals: } & 0.242 \\
Lab Alkalinity & 6.8 \\
* Bicarbonate computed from alkalinity
\end{tabular}

\begin{tabular}{|c|c|c|c|c|c|c|c|c|c|}
\hline \multicolumn{5}{|c|}{ Site Location: Whiskey Chitto Creek - site 6} & \multicolumn{3}{|c|}{ Date: November 5.1996} & \multicolumn{2}{|c|}{ Time: $\underline{0835}$} \\
\hline Cations & & $\mathrm{mg} / \mathrm{L}$ & $\mathrm{meq} / \mathrm{L}$ & percent & Anions & & $\mathrm{mg} / \mathrm{L}$ & $\mathrm{meq} / \mathrm{L}$ & percent \\
\hline Sodium & $\mathrm{Na}$ & 7.3 & 0.318 & 29.40 & Chloride & $\mathrm{Cl}$ & 7.5 & 0.212 & 22.79 \\
\hline Potassium & $\mathrm{K}$ & 1.8 & 0.047 & 4.33 & Fluoride & $\mathrm{F}$ & 0.1 & 0.005 & 0.57 \\
\hline Magnesium & $\mathrm{Mg}$ & 1.3 & 0.103 & 9.52 & Sulfate & $\mathrm{SO}_{4}$ & 7.5 & 0.156 & 16.82 \\
\hline Calcium & $\mathrm{Ca}$ & 12.3 & 0.613 & 56.74 & *Bicarbonate & $\mathrm{HCO}_{3}$ & 33.9 & 0.555 & 59.83 \\
\hline & & Totals: & 1.080 & & Carbonate & $\mathrm{CO}_{3}$ & 0.0 & 0.000 & 0.00 \\
\hline & & & & & & & Totals: & 0.928 & \\
\hline & & & & & Lab Alkalinity & & 27.8 & & \\
\hline & & & & & Bicarbonate $\mathrm{c}$ & d fro & kalir & & \\
\hline
\end{tabular}

\begin{tabular}{|c|c|c|c|c|c|c|c|c|c|}
\hline \multicolumn{5}{|c|}{ Site Location: Birds Creek - site 9} & \multicolumn{3}{|c|}{ Date: November 5.1996} & \multicolumn{2}{|c|}{ Time: 0840} \\
\hline Cations & & $\mathrm{mg} / \mathrm{L}$ & $\mathrm{meq} / \mathrm{L}$ & percent & Anions & & $\mathrm{mg} / \mathrm{L}$ & $\mathrm{meq} / \mathrm{L}$ & percent \\
\hline Sodium & $\mathrm{Na}$ & 2.6 & 0.113 & 29.28 & Chloride & $\mathrm{Cl}$ & 4.4 & 0.124 & 30.07 \\
\hline Potassium & $\mathrm{K}$ & 1.4 & 0.036 & 9.40 & Fluoride & $\mathrm{F}$ & 0.1 & 0.005 & 1.28 \\
\hline Magnesium & $\mathrm{Mg}$ & 0.9 & 0.076 & 19.59 & Sulfate & $\mathrm{SO}_{4}$ & 4.4 & 0.092 & 22.19 \\
\hline Calcium & $\mathrm{Ca}$ & 3.2 & 0.161 & 41.73 & *Bicarbonate & $\mathrm{HCO}_{3}$ & 11.7 & 0.192 & 46.46 \\
\hline & & Totals: & 0.386 & & Carbonate & $\mathrm{CO}_{3}$ & 0.0 & 0.000 & 0.00 \\
\hline & & & & & & & otals: & 0.413 & \\
\hline & & & & & Lab Alkalinity & & 9.6 & & \\
\hline & & & & & Bicarbonate $\mathrm{c}$ & fro & alkalir & & \\
\hline
\end{tabular}


Table 13. Major inorganic ion data for daily sampling sites in the Limited Use Area, Vernon Ranger District, Kisatchie National Forest, Louisiana--Continued

\begin{tabular}{|c|c|c|c|c|c|c|c|c|}
\hline \multicolumn{4}{|c|}{ Site Location: Whiskey Chitto Creek - site 7} & \multicolumn{3}{|c|}{ Date: November 5, 1996} & \multicolumn{2}{|c|}{ Time: $\underline{0850}$} \\
\hline Cations & $\mathrm{mg} / \mathrm{L}$ & $\mathrm{meq} / \mathrm{L}$ & percent & Anions & & $\mathrm{mg} / \mathrm{L}$ & $\mathrm{meq} / \mathrm{L}$ & percent \\
\hline Sodium $\mathrm{Na}$ & 5.0 & 0.218 & 28.01 & Chloride & $\mathrm{Cl}$ & 5.6 & 0.158 & 23.61 \\
\hline Potassium $\mathrm{K}$ & 1.4 & 0.035 & 4.51 & Fluoride & F & 0.1 & 0.005 & 0.79 \\
\hline Magnesium $\mathrm{Mg}$ & 1.1 & 0.093 & 11.97 & Sulfate & $\mathrm{SO}_{4}$ & 5.6 & 0.117 & 17.43 \\
\hline \multirow[t]{5}{*}{ Calcium $\mathrm{Ca}$} & 8.6 & 0.431 & 55.51 & *Bicarbonate & $\mathrm{HCO}_{3}$ & 23.7 & 0.389 & 58.17 \\
\hline & Totals: & 0.777 & & Carbonate & $\mathrm{CO}_{3}$ & 0.0 & 0.000 & 0.00 \\
\hline & & & & & & otals: & 0.669 & \\
\hline & & & & Lab Alkalinity & & 19.5 & & \\
\hline & & & & * Bicarbonate c & 2110 & alkalin & & \\
\hline
\end{tabular}

\begin{tabular}{|c|c|c|c|c|c|c|c|c|}
\hline \multicolumn{4}{|c|}{ Site Location: West Fork of Sixmile Creek - site 11} & \multicolumn{3}{|c|}{ Date: November 5,1996} & \multicolumn{2}{|c|}{ Time: $\underline{0900}$} \\
\hline Cations & $\mathrm{mg} / \mathrm{L}$ & $\mathrm{meq} / \mathrm{L}$ & percent & Anions & & $\mathrm{mg} / \mathrm{L}$ & $\mathrm{meq} / \mathrm{L}$ & percent \\
\hline Sodium $\mathrm{Na}$ & 1.9 & 0.083 & 43.86 & Chloride & $\mathrm{Cl}$ & 3.1 & 0.087 & 33.21 \\
\hline Potassium $\mathrm{K}$ & 0.8 & 0.021 & 11.34 & Fluoride & $\mathrm{F}$ & 0.1 & 0.005 & 2.00 \\
\hline Magnesium $\mathrm{Mg}$ & 0.5 & 0.042 & 22.15 & Sulfate & $\mathrm{SO}_{4}$ & 3.3 & 0.069 & 26.09 \\
\hline \multirow[t]{5}{*}{ Calcium $\mathrm{Ca}$} & 0.9 & 0.043 & 22.65 & *Bicarbonate & $\mathrm{HCO}_{3}$ & 6.2 & 0.102 & 38.70 \\
\hline & Totals: & 0.189 & & Carbonate & $\mathrm{CO}_{3}$ & 0.0 & 0.000 & 0.00 \\
\hline & & & & & & otals: & 0.263 & \\
\hline & & & & Lab Alkalinity & & 5.1 & & \\
\hline & & & & * Bicarbonate c & ed fro & alkalin & & \\
\hline
\end{tabular}

\begin{tabular}{|c|c|c|c|c|c|c|c|c|}
\hline \multicolumn{4}{|c|}{ Site Location: East Fork of Sixmile Creek - site 13} & \multicolumn{3}{|c|}{ Date: November 5.1996 } & \multicolumn{2}{|c|}{ Time: $\underline{0900}$} \\
\hline Cations & $\mathrm{mg} / \mathrm{L}$ & $\mathrm{meq} / \mathrm{L}$ & percent & \multicolumn{3}{|c|}{ Anions $\quad \mathrm{mg} / \mathrm{L}$} & $\mathrm{meq} / \mathrm{L}$ & percent \\
\hline Sodium $\mathrm{Na}$ & 2.0 & 0.087 & 42.23 & Chloride & $\mathrm{Cl}$ & 3.3 & 0.093 & 33.61 \\
\hline Potassium $\mathrm{K}$ & 0.9 & 0.023 & 11.17 & Fluoride & $\mathrm{F}$ & 0.1 & 0.005 & 1.90 \\
\hline Magnesium $\mathrm{Mg}$ & 0.5 & 0.041 & 19.96 & Sulfate & $\mathrm{SO}_{4}$ & 3.3 & 0.069 & 24.81 \\
\hline \multirow[t]{5}{*}{ Calcium $\mathrm{Ca}$} & 1.1 & 0.055 & 26.64 & *Bicarbonate & $\mathrm{HCO}_{3}$ & 6.7 & 0.110 & 39.68 \\
\hline & Totals: & 0.206 & & Carbonate & $\mathrm{CO}_{3}$ & 0.0 & 0.000 & 0.00 \\
\hline & & & & \multicolumn{3}{|c|}{ Totals: } & 0.277 & \\
\hline & & & \multirow{2}{*}{\multicolumn{6}{|c|}{ * Bicarbonate computed from alkalinity }} \\
\hline & & & & & & & & \\
\hline
\end{tabular}

\begin{tabular}{|c|c|c|c|c|c|c|c|c|}
\hline \multicolumn{4}{|c|}{ Site Location: Sixmile Creek - site 15} & \multicolumn{3}{|c|}{ Date: November 5,1996} & \multicolumn{2}{|c|}{ Time: $\underline{0900}$} \\
\hline Cations & $\mathrm{mg} / \mathrm{L}$ & $\mathrm{meq} / \mathrm{L}$ & percent & Anions & & $\mathrm{mg} / \mathrm{L}$ & $\mathrm{meq} / \mathrm{L}$ & percent \\
\hline Sodium $\mathrm{Na}$ & 2.6 & 0.113 & 44.16 & Chloride & $\mathrm{Cl}$ & 3.9 & 0.110 & 33.90 \\
\hline Potassium $\mathrm{K}$ & 1.0 & 0.026 & 9.98 & Fluoride & $\mathrm{F}$ & 0.1 & 0.005 & 1.62 \\
\hline Magnesium $\mathrm{Mg}$ & 0.7 & 0.058 & 22.48 & Sulfate & $\mathrm{SO} 4$ & 3.9 & 0.081 & 25.02 \\
\hline \multirow[t]{5}{*}{ Calcium $\mathrm{Ca}$} & 1.2 & 0.060 & 23.38 & *Bicarbonate & $\mathrm{HCO} 3$ & 7.8 & 0.128 & 39.46 \\
\hline & Totals: & 0.256 & & Carbonate & $\mathrm{CO} 3$ & 0.0 & 0.000 & 0.00 \\
\hline & & & & & & Totals: & 0.325 & \\
\hline & & & & Lab Alkalinity & & 6.4 & & \\
\hline & & & & * Bicarbonate $\mathrm{c}$ & ted fror & alkalin & & \\
\hline
\end{tabular}


Table 14. Percent silt, sand, and gravel of sediments collected from sampling sites in the Limited Use Area, Vernon Ranger District, Kisatchie National Forest, Louisiana

\begin{tabular}{|c|c|c|c|c|}
\hline $\begin{array}{c}\text { Site } \\
\text { number }\end{array}$ & $\begin{array}{c}\text { Station } \\
\text { Identification }\end{array}$ & Loca & & \\
\hline \multirow[t]{2}{*}{1} & 3059300931307 & \multicolumn{3}{|c|}{ Bundick Creek $\sim 400 \mathrm{ft}$ south of bridge on Forest Service Road 422.} \\
\hline & silt $\quad 2.2 \%$ & sand & $97.8 \%$ & -- \\
\hline \multirow[t]{2}{*}{2} & 3056310931205 & \multicolumn{3}{|c|}{ Bundick Creek $\sim 200 \mathrm{ft}$ north of bridge on Forest Service Road 410 . } \\
\hline & silt $\quad 0.4 \%$ & sand & $99.6 \%$ & -- \\
\hline \multirow[t]{2}{*}{3} & 3100130930901 & \\
\hline & silt $\quad 1.6 \%$ & \multicolumn{3}{|c|}{$\begin{array}{l}\text { Drakes Creek } \sim 200 \mathrm{ft} \text { north of bridge on Forest Service Road } 421 . \\
\text { sand } 98.4 \% \quad \text { gravel -- }\end{array}$} \\
\hline \multirow[t]{2}{*}{4} & 3057520930817 & \multicolumn{3}{|c|}{ Drakes Creek $\sim 300 \mathrm{ft}$ north of bridge on Louisiana Highway 10 . } \\
\hline & silt $\quad 0.6 \%$ & sand & $99.4 \%$ & -- \\
\hline \multirow[t]{2}{*}{5} & 3056430930641 & \multicolumn{3}{|c|}{ Drakes Creek $\sim 200 \mathrm{ft}$ southeast of bridge on Forest Service Road 402 . } \\
\hline & silt $\quad 0.4 \%$ & sand & $55.8 \%$ & $43.8 \%$ \\
\hline \multirow[t]{2}{*}{6} & 3100320930449 & \multicolumn{3}{|c|}{ Whiskey Chitto Creek near Leesville $\sim 400 \mathrm{ft}$ south of bridge $\mathrm{H}-7$ on Lookout Road. } \\
\hline & silt $\quad 0.7 \%$ & sand & $38.3 \%$ & $61 \%$ \\
\hline \multirow[t]{2}{*}{7} & 3058470930323 & \multicolumn{3}{|c|}{ Whiskey Chitto Creek $200 \mathrm{ft}$ northwest of bridge on Ray Gill Road east of Leesville. } \\
\hline & silt & sand & gravel & -- \\
\hline \multirow[t]{2}{*}{8} & 3057260930324 & \multicolumn{3}{|c|}{ Whiskey Chitto Creek $200 \mathrm{ft}$ north of old Athison Topeka and Santa Fe railroad bridge. } \\
\hline & $1.9 \%$ & sand & $98.1 \%$ & -- \\
\hline \multirow[t]{2}{*}{9} & 3101150930312 & \multicolumn{3}{|c|}{ Birds Creek near Cravens $\sim 200 \mathrm{ft}$ south of bridge H-8 on Lookout Road. } \\
\hline & $0.9 \%$ & sand & $39.1 \%$ & $60.0 \%$ \\
\hline 10 & 3059330930149 & Little & ixmile Creek near th & e end of Gravel Pit Cutoff Road. \\
\hline & $0.2 \%$ & sand & $37.3 \%$ & $62.5 \%$ \\
\hline 11 & 3102180930014 & West & ork of Sixmile Creel & north of Pitkin $\sim 400 \mathrm{ft}$ south of bridge H-9 on Lookout Road. \\
\hline & N/A & sand & gravel & N/A \\
\hline 12 & 3100300925919 & West & ork of Sixmile Cree & $\sim 750 \mathrm{ft}$ west of Fullerton Lake. \\
\hline & $0.6 \%$ & sand & $99.4 \%$ & -- \\
\hline 13 & 3102030925802 & East $\mathrm{F}$ & ork of Sixmile Creek & north of Pitkin $\sim 250 \mathrm{ft}$ south of bridge on Lookout Road. \\
\hline & $0.6 \%$ & sand & $72.1 \%$ & $27.3 \%$ \\
\hline 14 & 3100100925753 & East $\mathrm{F}$ & ork of Sixmile Creek & 200 ft northeast of bridge on Fullerton Blacktop Road (FS 412). \\
\hline & silt $\quad 0.2 \%$ & sand & $72.5 \%$ & $27.3 \%$ \\
\hline
\end{tabular}




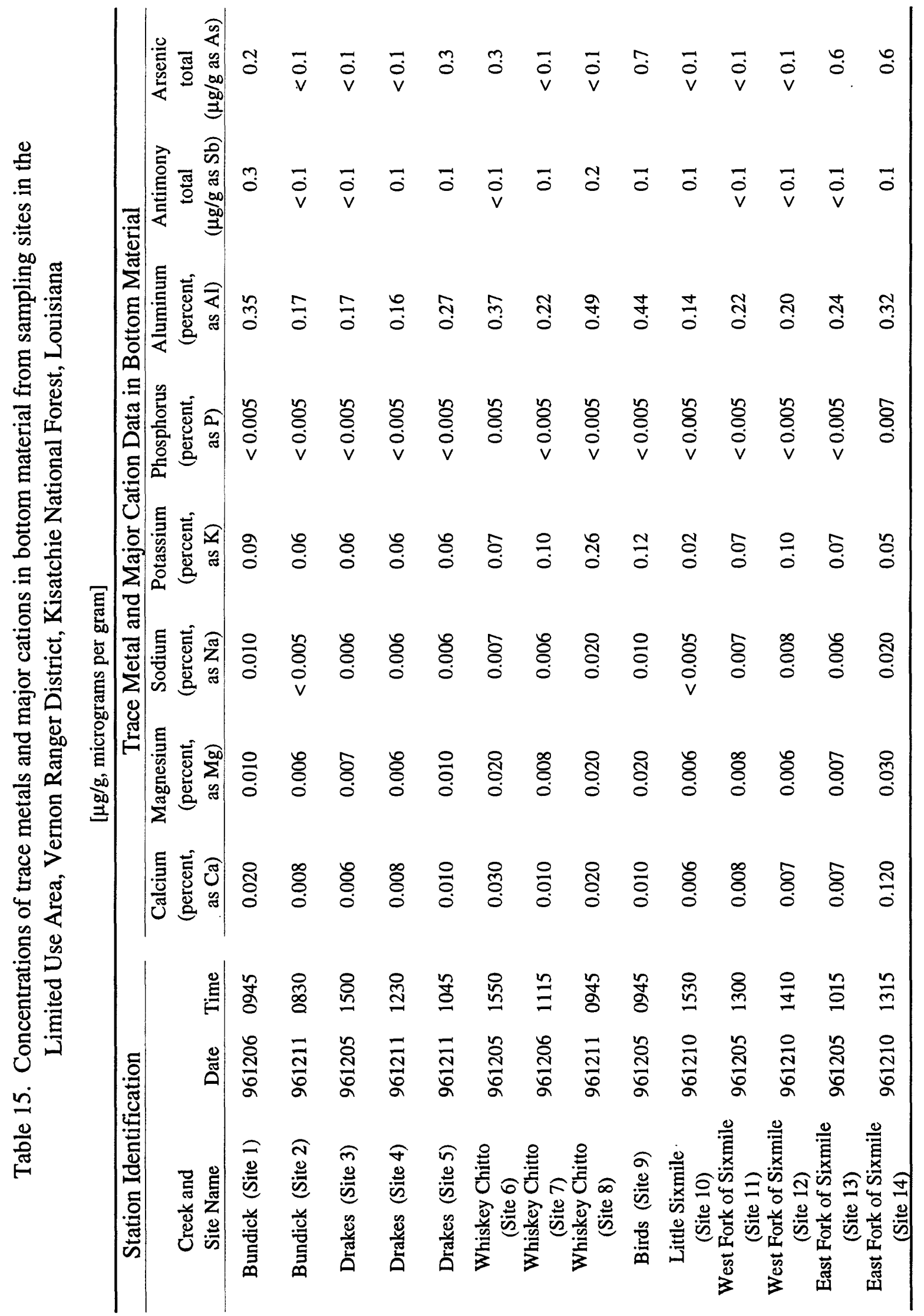




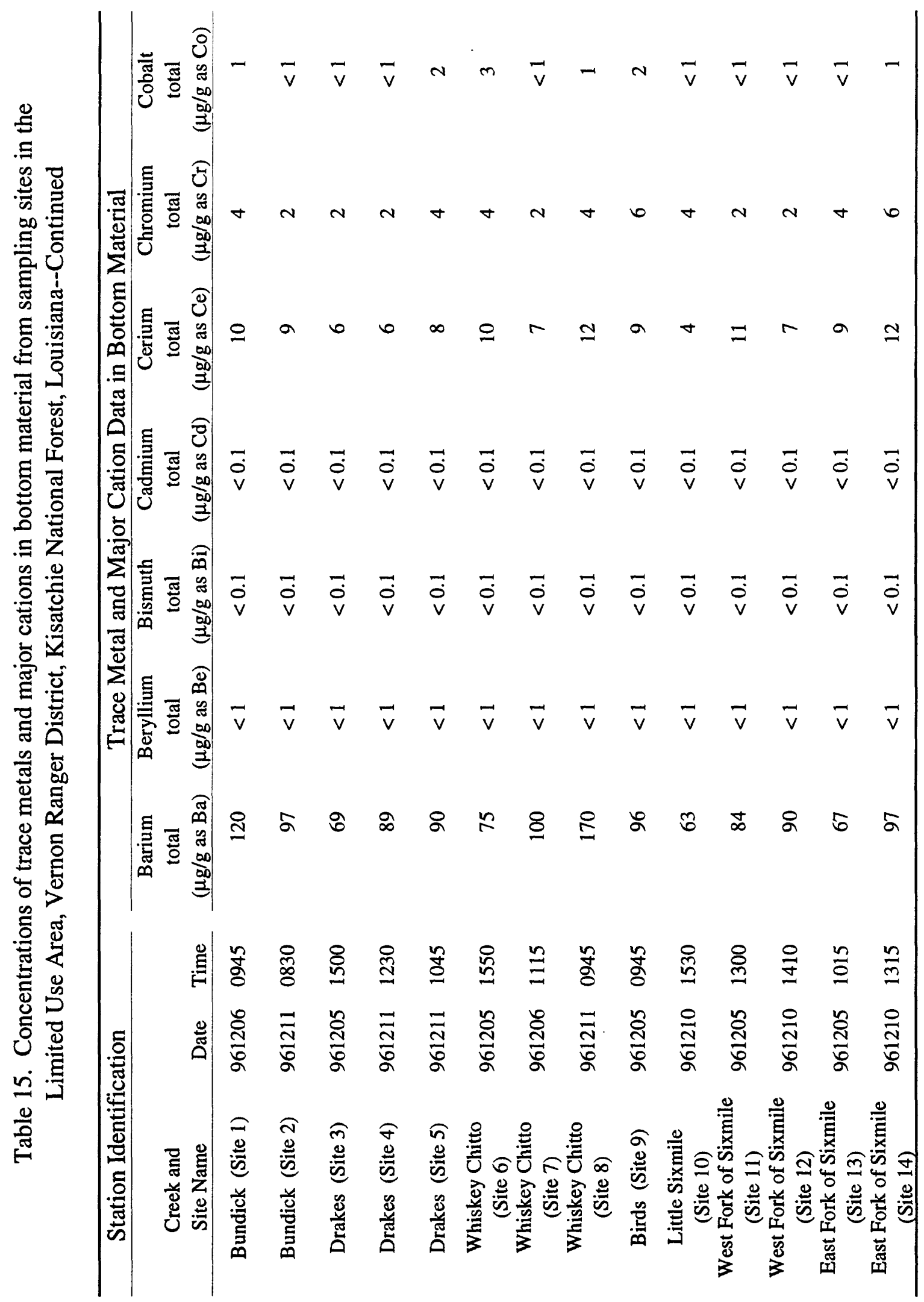




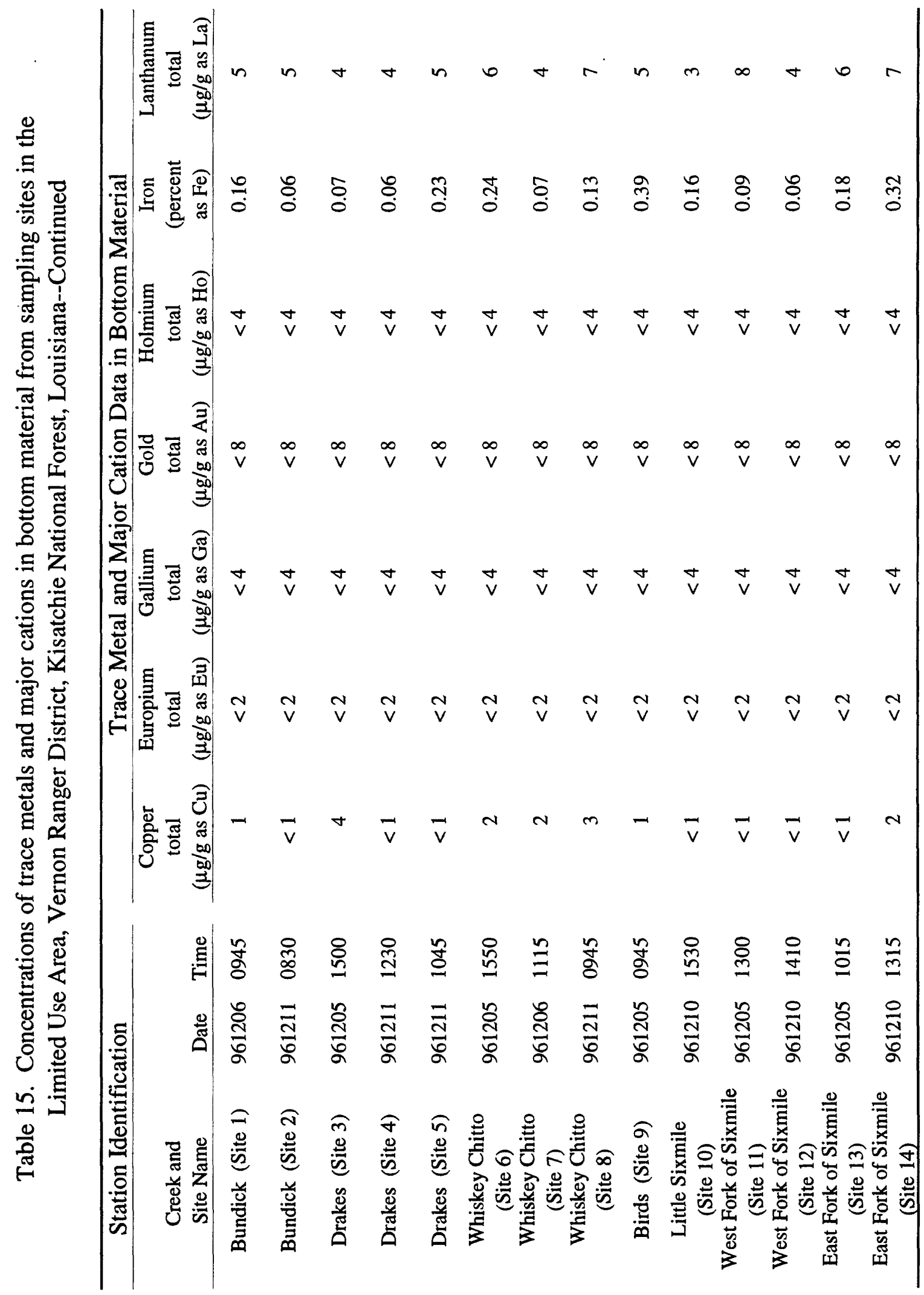




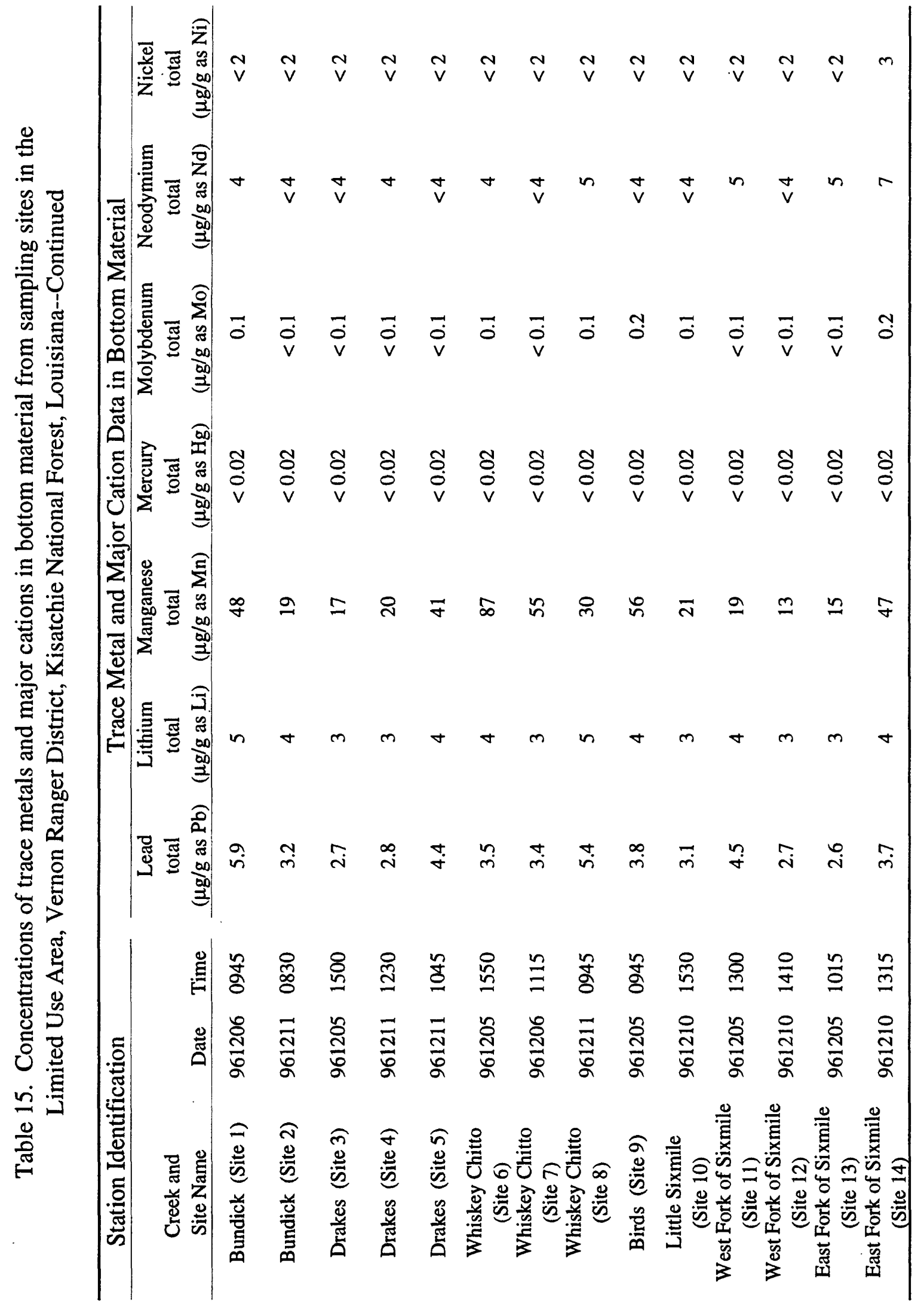




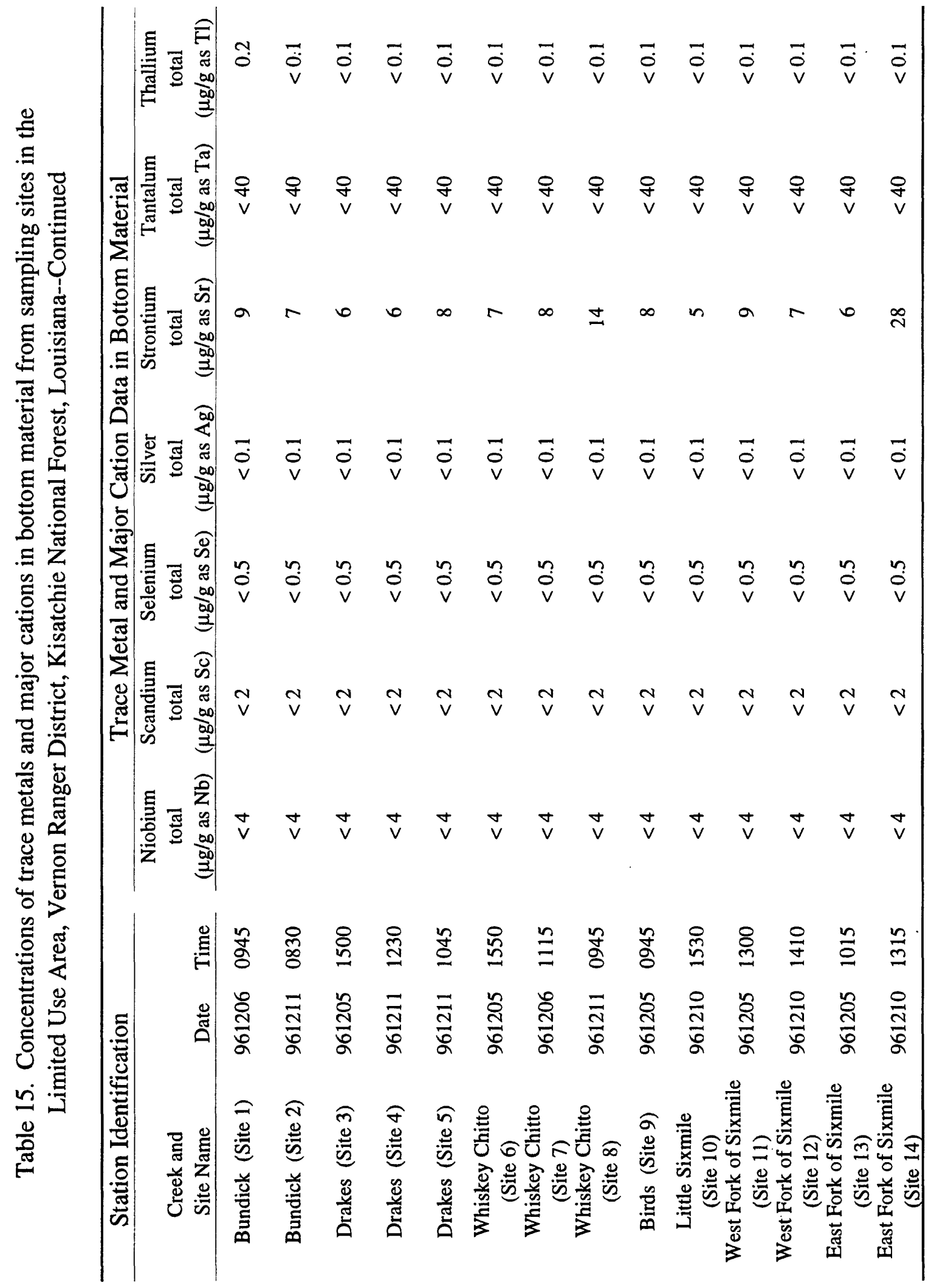




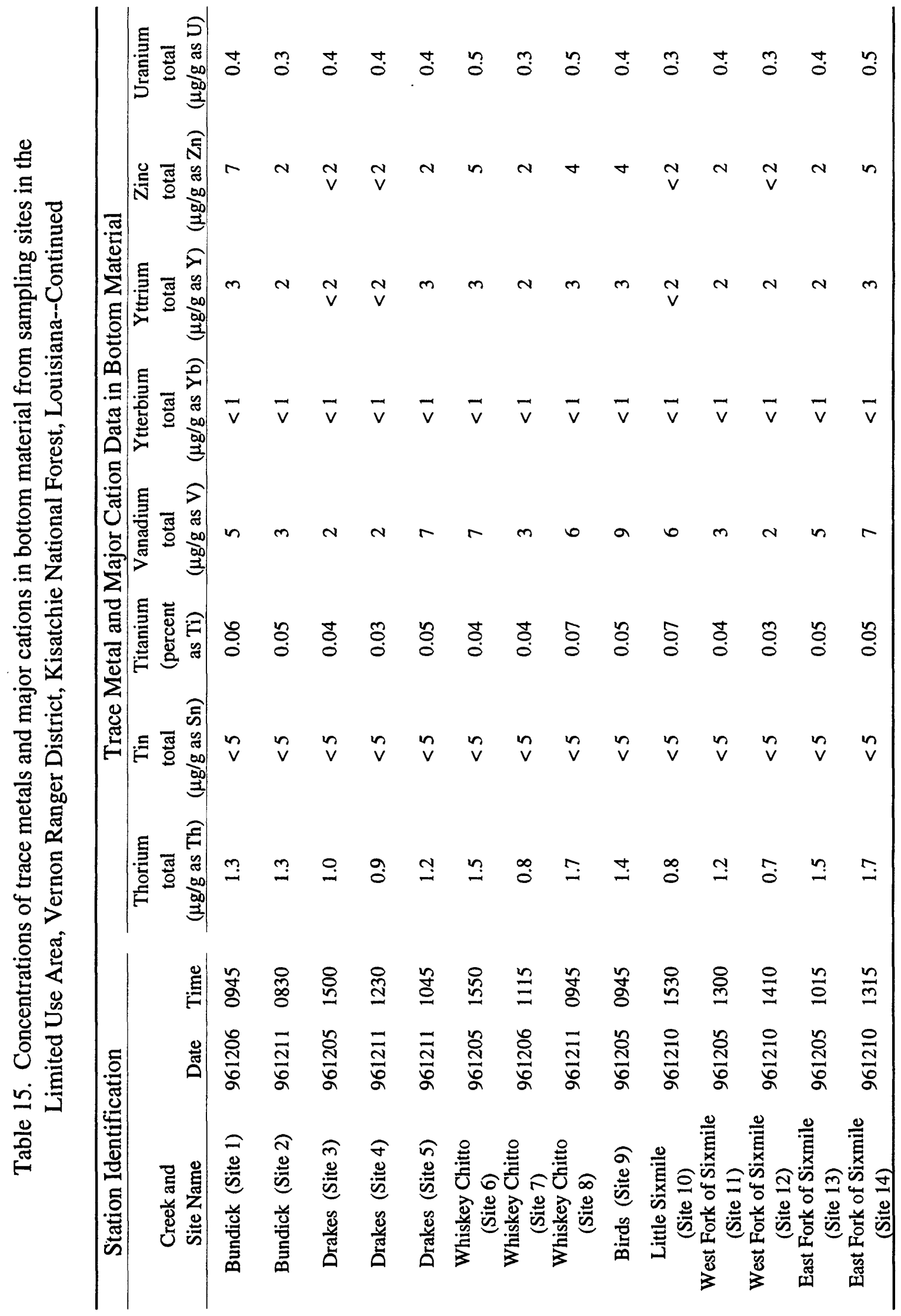




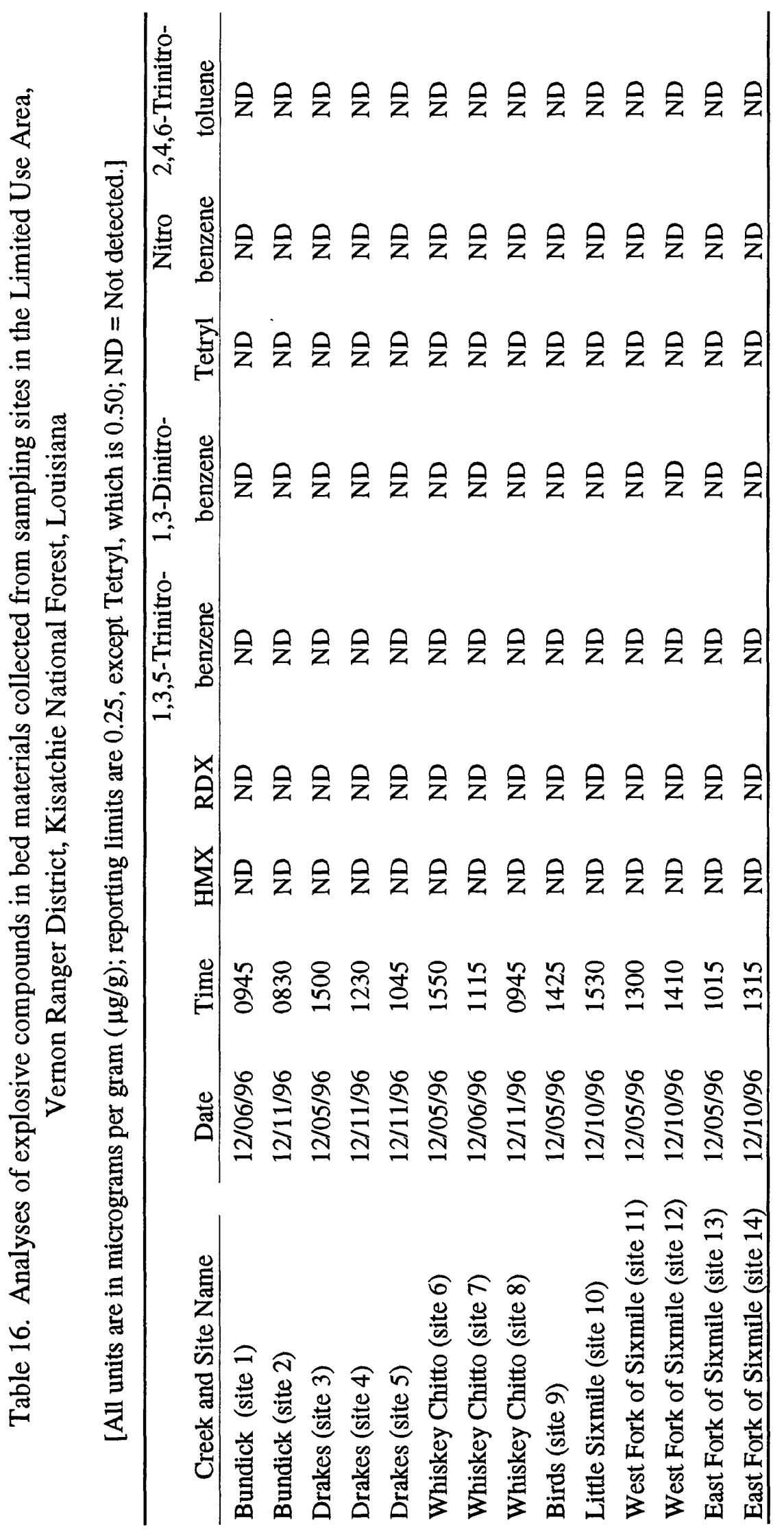




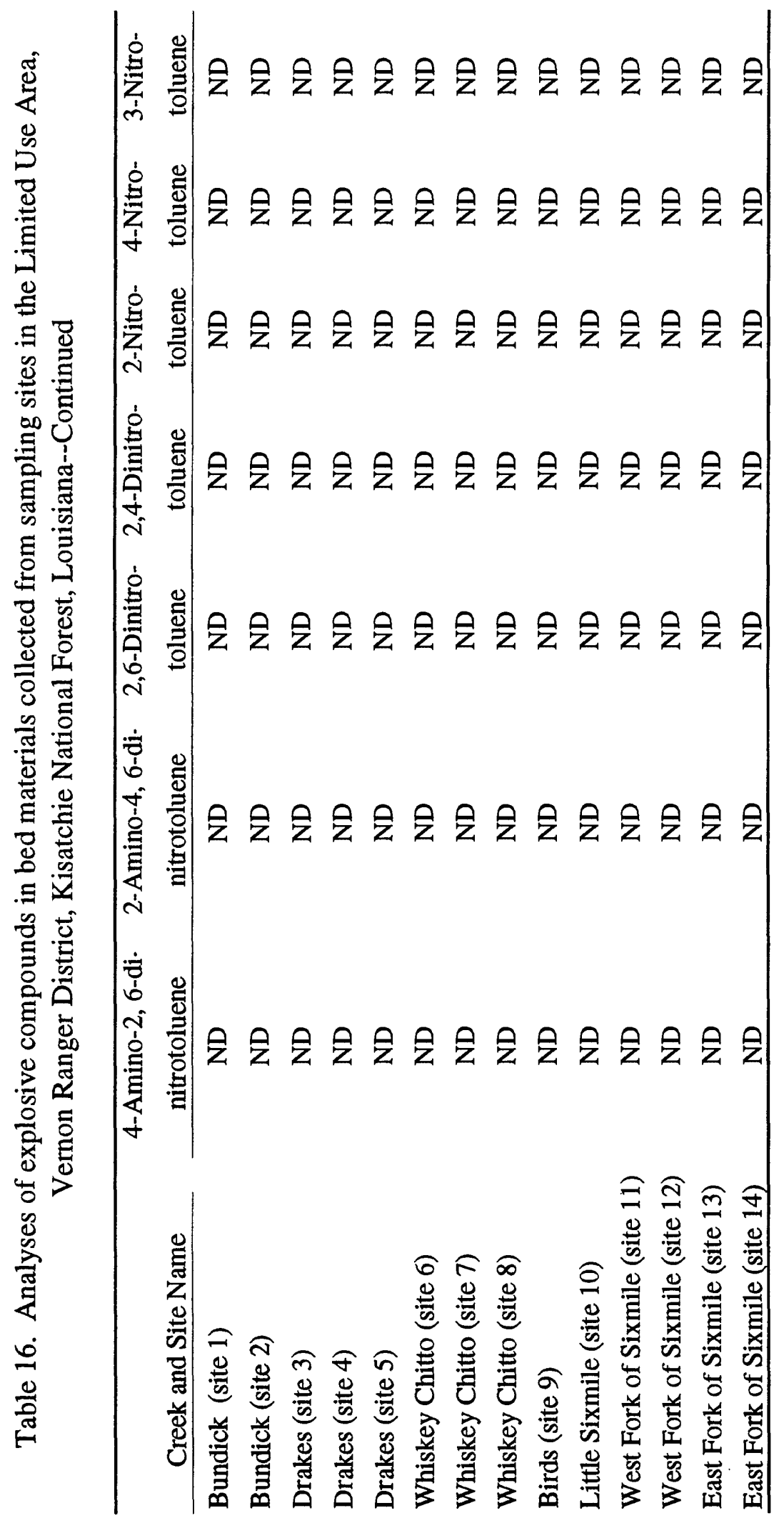




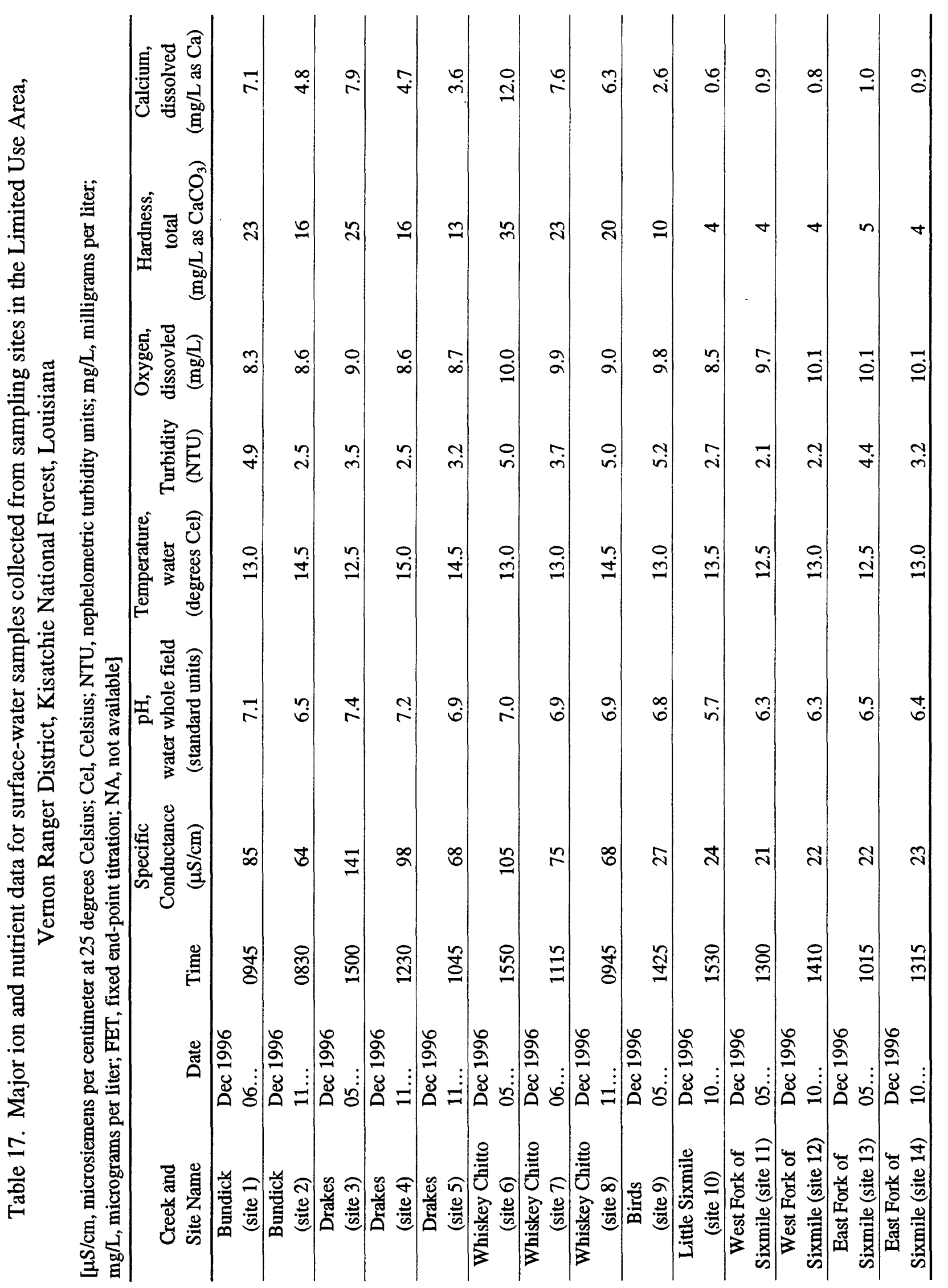




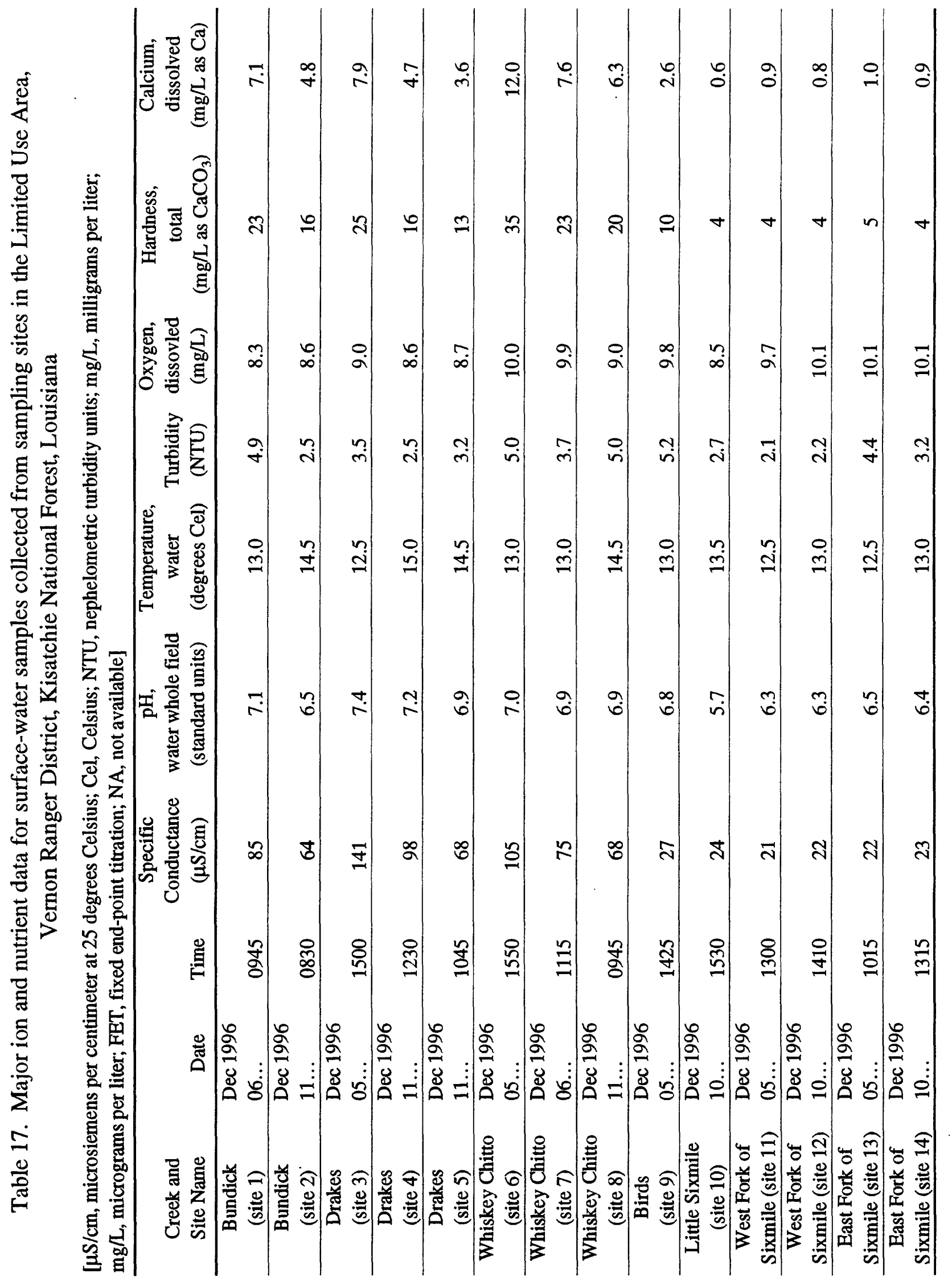




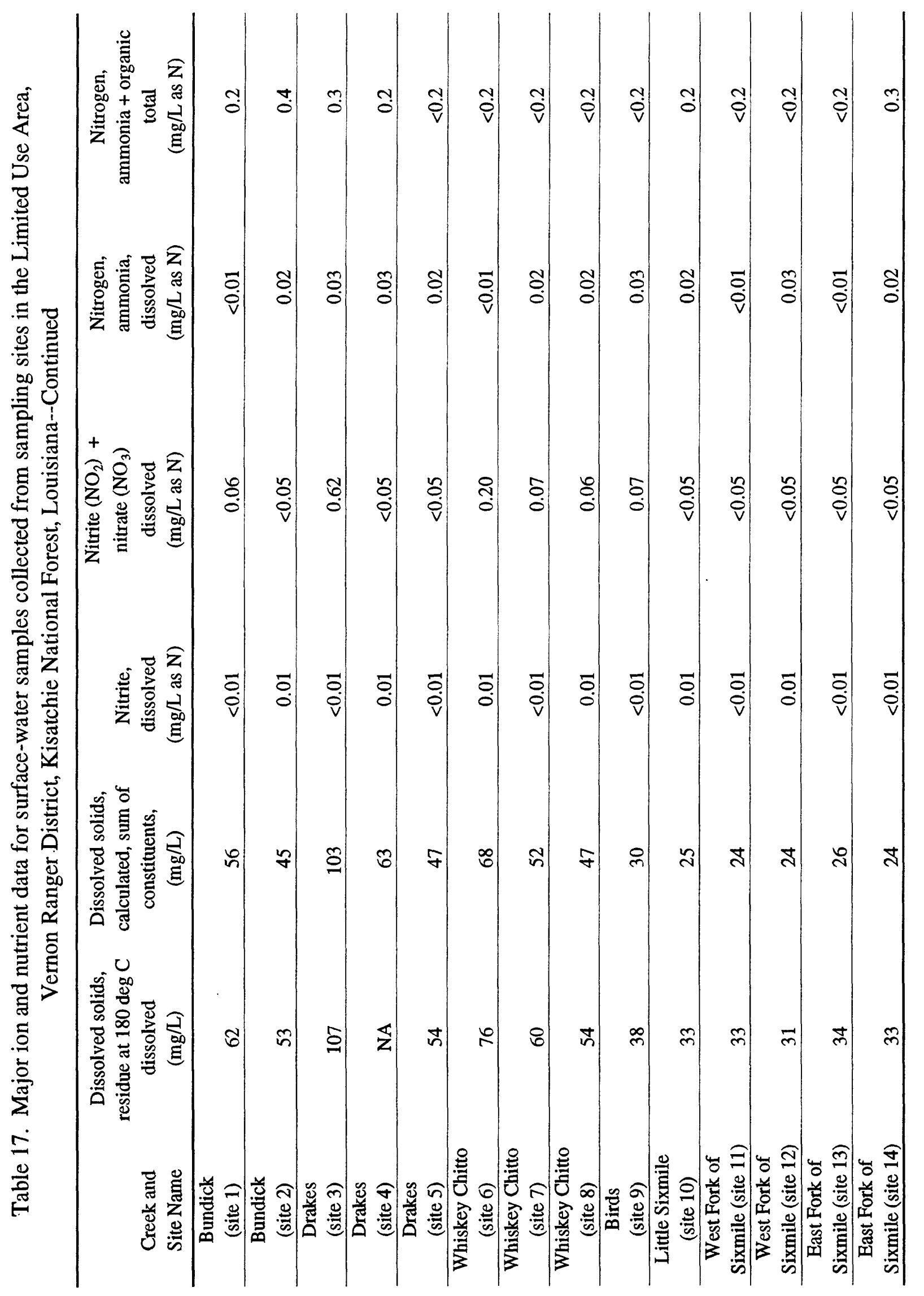




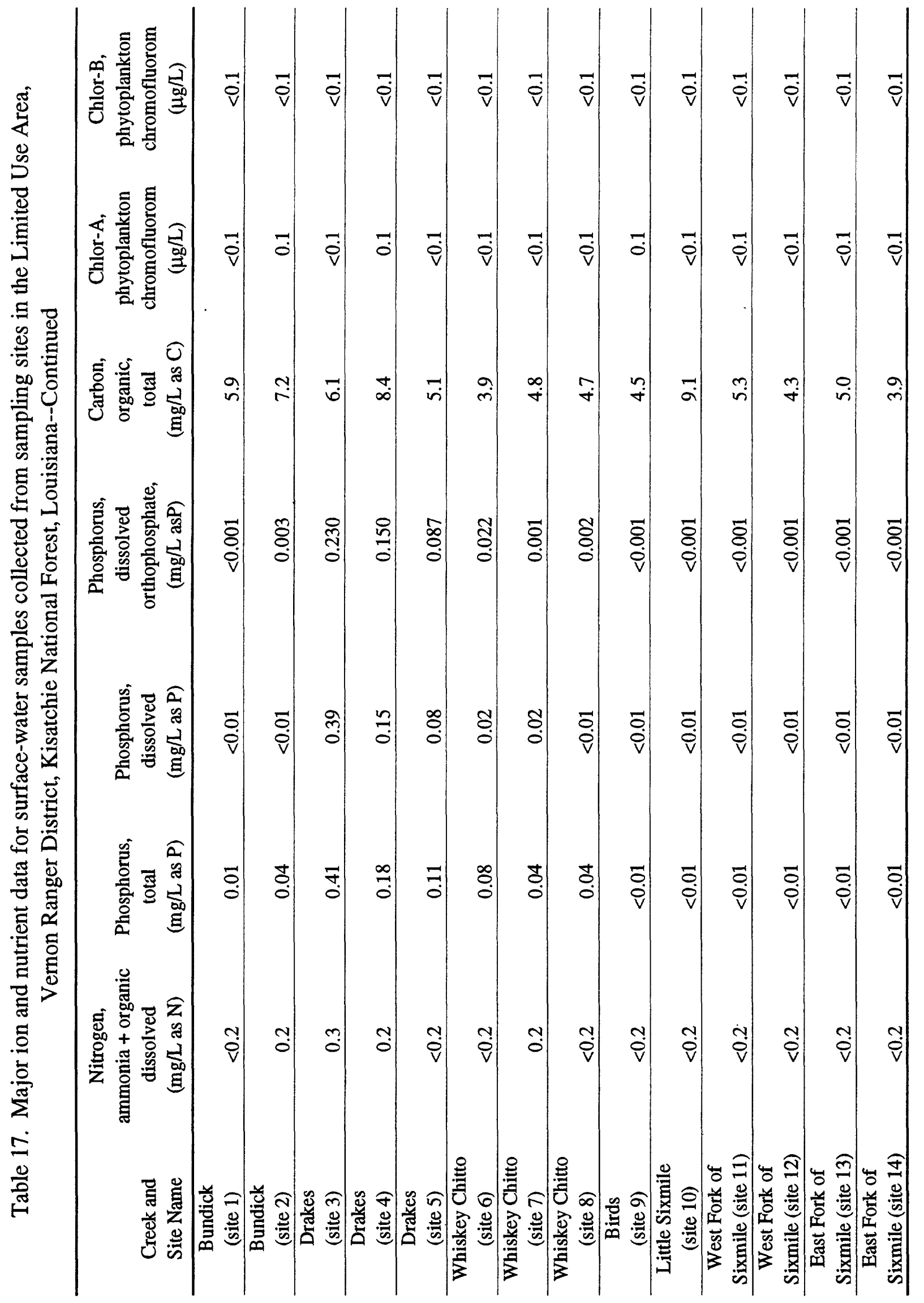


Table 18. Percent difference of cation/anion balance values for water samples collected from sampling sites in the Limited Use Area, Vernon Ranger District, Kisatchie National Forest, Louisiana

\begin{tabular}{|c|c|c|c|c|c|}
\hline Site no & Station & ID. & Locatior & & \\
\hline 1 & 3059300 & 931307 & Bundick & Creek $\sim 400 \mathrm{ft}$ south of bridge ol & n Forest Service Road 422. \\
\hline & cations & $0.793^{1}$ & anions & $0.776^{1}$ percent difference ${ }^{2}$ & 1.11 \\
\hline 2 & 3056310 & 931205 & Bundick & Creek $\sim 200 \mathrm{ft}$ north of bridge or & Forest Service Road 410. \\
\hline & cations & 0.604 & anions & percent difference & 2.49 \\
\hline 3 & 3100130 & 930901 & Drakes C & Creek $200 \mathrm{ft}$ north of bridge on & Forest Service Road 421. \\
\hline & cations & 1.522 & anions & 1.452 percent difference & 2.37 \\
\hline 4 & 3057520 & 930817 & Drakes C & Creek $\sim 300 \mathrm{ft}$ north of bridge on & LA 10. \\
\hline & cations & 0.932 & anions & 0.889 percent difference & 2.39 \\
\hline 5 & 3056430 & 930641 & Drakes C & Creek $\sim 200 \mathrm{ft}$ southeast of bridge & on Forest Service Road 402. \\
\hline & cations & 0.624 & anions & 0.607 percent difference & 1.38 \\
\hline 6 & 3100320 & 930449 & Whiskey & Chitto Creek near Leesville $\sim 40$ & $0 \mathrm{ft}$ south of bridge $\mathrm{H}-7$ on Lookout Road. \\
\hline$\cdot$ & cations & 0.956 & anions & 0.909 percent difference & 2.53 \\
\hline 7 & 3058470 & 930323 & Whiskey & Chitto Creek $\sim 200 \mathrm{ft}$ northwest & of bridge on Ray Gill Road east of Leesville. \\
\hline & cations & 0.674 & anions & 0.679 percent difference & -0.39 \\
\hline 8 & 3057260 & 930324 & Whiskey & Chitto Creek $\sim 200 \mathrm{ft}$ north of ol & Id Athison Topeka and Santa Fe railroad bridge. \\
\hline & cations & 0.613 & anions & 0.611 percent difference & 0.17 \\
\hline 9 & 3101150 & 930312 & Birds Cr & eek near Cravens $\sim 200 \mathrm{ft}$ south o & f bridge $\mathrm{H}-8$ on Lookout Road. \\
\hline & cations & 0.341 & anions & 0.340 percent difference & 0.12 \\
\hline 10 & 3059330 & 930149 & Little Six & xmile Creek near the end of Grav & rel Pit Cutoff Road. \\
\hline & cations & 0.182 & anions & 0.199 percent difference & -4.51 \\
\hline 11 & 3102180 & 930014 & West For & rk of Sixmile Creek north of Pitk & in $\sim 400 \mathrm{ft}$ south of bridge $\mathrm{H}-9$ on Lookout Road. \\
\hline & cations & 0.202 & anions & percent difference & 1.42 \\
\hline 12 & 3100300 & 925919 & West For & rk of Sixmile Creek $\sim 750 \mathrm{ft}$ west & of Fullerton Lake. \\
\hline & cations & 0.186 & anions & 0.191 percent difference & -1.28 \\
\hline 13 & 3102030 & 925802 & East Fork & $\mathrm{k}$ of Sixmile Creek north of Pitki & in $\sim 250 \mathrm{ft}$ south of bridge on Lookout Road. \\
\hline & cations & 0.209 & anions & 0.210 percent difference & -0.02 \\
\hline 14 & 3100100 & 925753 & East Fork & $\mathrm{k}$ of Sixmile Creek $\sim 200 \mathrm{ft}$ north & east of bridge on Fullerton Blacktop Road (FS 412). \\
\hline & cations & 0.197 & anions & 0.211 percent difference & -3.51 \\
\hline
\end{tabular}


Table 19. Analyses of bacteria in surface-water samples collected from sampling sites in the Limited Use Area, Vernon Ranger District, Kisatchie National Forest, Louisiana

\begin{tabular}{|c|c|c|}
\hline Creek and Site Name & $\begin{array}{c}\text { Fecal Coliform } \\
\text { (collonies per } \\
100 \text { milliliters) }\end{array}$ & $\begin{array}{c}\text { Fecal Streptococcus } \\
\text { (collonies per } \\
100 \text { milliliters) }\end{array}$ \\
\hline Bundick (site 1) & 100 & 96 \\
\hline Bundick (site 2) & 200 & 880 \\
\hline Drakes（site 3) & 66 & 106 \\
\hline Drakes（site 4) & 330 & 112 \\
\hline Drakes (site 5) & 110 & 310 \\
\hline Whiskey Chitto (site 6) & 216 & 118 \\
\hline Whiskey Chitto (site 7) & 122 & 380 \\
\hline Whiskey Chitto (site 8) & 110 & 350 \\
\hline Birds (site 9) & 230 & 570 \\
\hline Little Sixmile (site 10) & 90 & 76 \\
\hline West Fork of Sixmile (site 11) & 250 & 92 \\
\hline West Fork of Sixmile (site 12) & 600 & 370 \\
\hline East Fork of Sixmile (site 13) & 500 & 150 \\
\hline East Fork of Sixmile (site 14) & 160 & 840 \\
\hline
\end{tabular}




\section{APPENDIX A: \\ PERIPHYTON ANALYSES FOR SAMPLES COLLECTED FROM SITES IN THE LIMITED USE AREA, VERNON RANGER DISTRICT, KISATCHIE NATIONAL FOREST, LOUISIANA}

\section{CONTENTS}

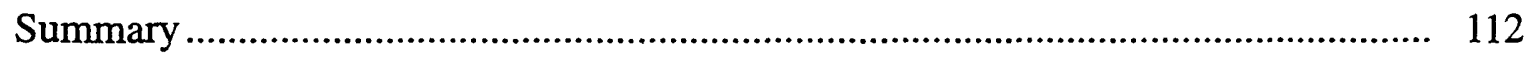

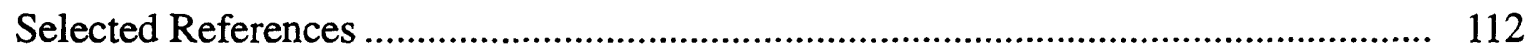

Table A1. Periphyton counts for samples collected from sampling sites in the Limited Use Area, Vernon Ranger District, Kisatchie National Forest, Louisiana.

Table A2. Periphyton counts for replicate samples collected at sampling sites in the Limited Use Area, Vernon Ranger District, Kisatchie National Forest, Louisiana

PREPARED BY FRED BRYAN

U.S. GEOLOGICAL SURVEY 


\section{SUMMARY}

Diatoms were usually the most speciose group of periphyton in the samples collected from the sampling sites in the Limited Use Area (LUA), Vernon Ranger District, Kisatchie National Forest, Louisiana. However, when the scrapings were predominantly filamentous, a few taxa, representing blue-green algae, green algae, or red algae, were the most abundant in terms of biomass. Some algae (i.e. Tuomeya sp.) were not quantifiable, using the utermohl procedure for enumerating plankton. In general, periphyton algal communities in stream sites near Fort Polk are representative of communities found in mineral-poor waters, low in alkaline earths and in buffering capacity, as described in other localities in the United States. Periphyton counts for samples collected from the sampling sites in the LUA are listed in table A1. Periphyton counts for replicate samples collected from the sampling sites in the LUA are listed in table A2. Replicate sample counts do not match original counts; however, replicate sample counts provide a good measure to confirm major taxa in biological communities.

\section{SELECTED REFERENCES}

American Public Health Association, American Water Works Association, and Water Environment Ferderation (APHA, AWWA, and WEF), 1992. Standard Methods for the Examination of Water and Wastewater, 18th ed. American Public Health Association, Washington, D.C. $1000+$ pp.

Bold, Harold C. and M. J. Wynne. 1985. Introduction to the Algae. Sec. ed. Prentice-Hall Inc., Englewood cliffs, N.J. 720pp.

Dodd, J. J. 1987. The Illustrated Flora of Illinois. Diatoms. Southern Illinois Univ. Press. Carbondale, IL. $477 \mathrm{pp}$.

Patrick, R. and C. W. Reimer. 1966. The Diatoms of the United States. Volume 1. Monographs of the Academy of Natural Sciences of Philadelphia. Number 13, 688pp.

Patrick, R. and C. W. Reimer. 1975. The Diatoms of the United States. Volume 2, Part 1. Monographs of the Academy of Natural Sciences of Philadelphia. Number 13, 213pp.

Prescott, G. W. 1968. Algae of the Western Great Lakes Area with an Illustrated Key to the Gerera of Desmids and Freshwater Diatoms. Wm. C. Brown Company Publishers, Dubuque, Iowa. 977pp.

Smith, Gilbert M. 1950. The Freshwater Algae of the United States. Second ed. McGraw-Hill Book Company, Inc. New York. N.Y. 719pp.

Whitford, L. A. and G. J. Shumacher. 1973. A Manual of Fresh-Water Algae. Sparks Press, Raleigh, N.C. 324pp. 


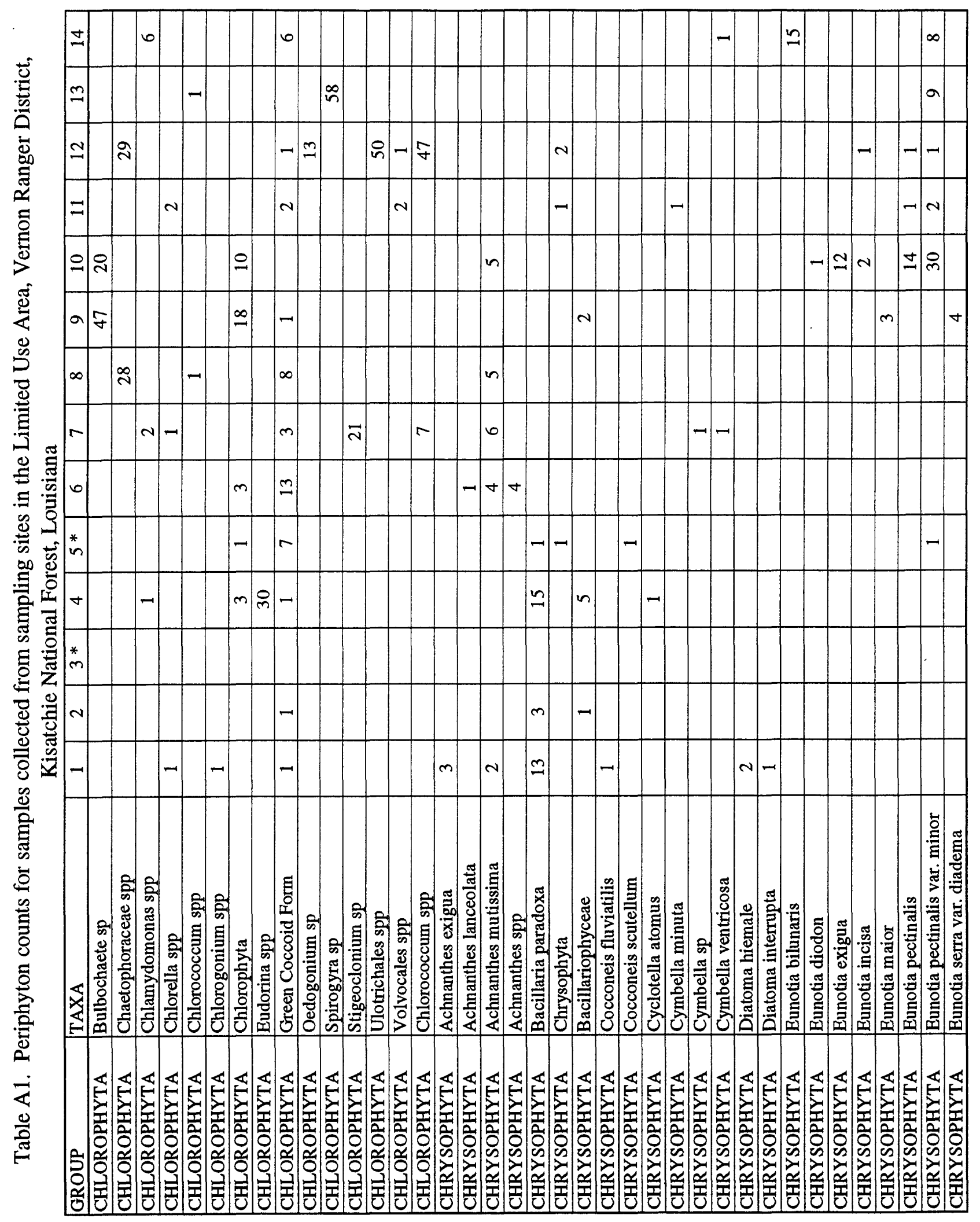




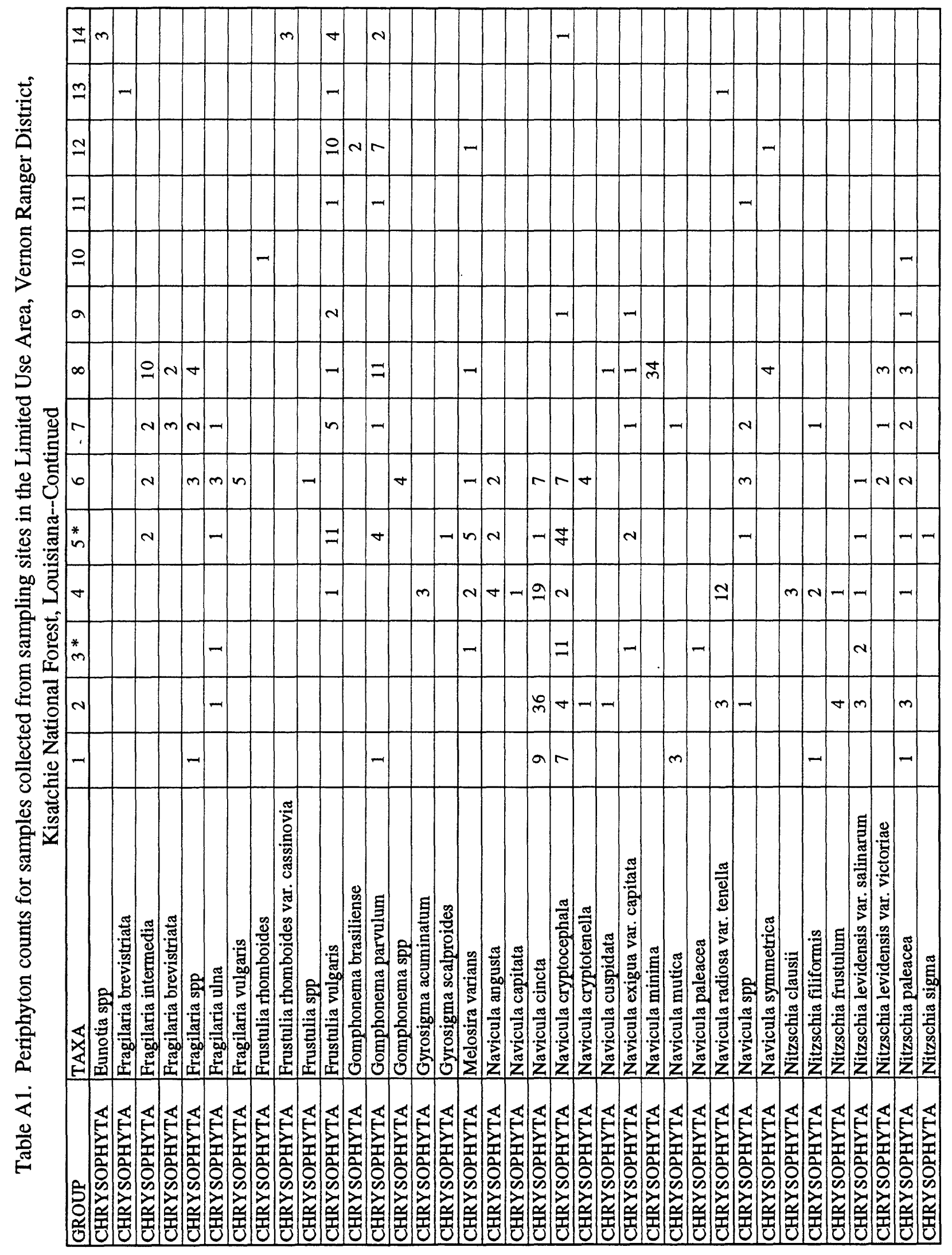




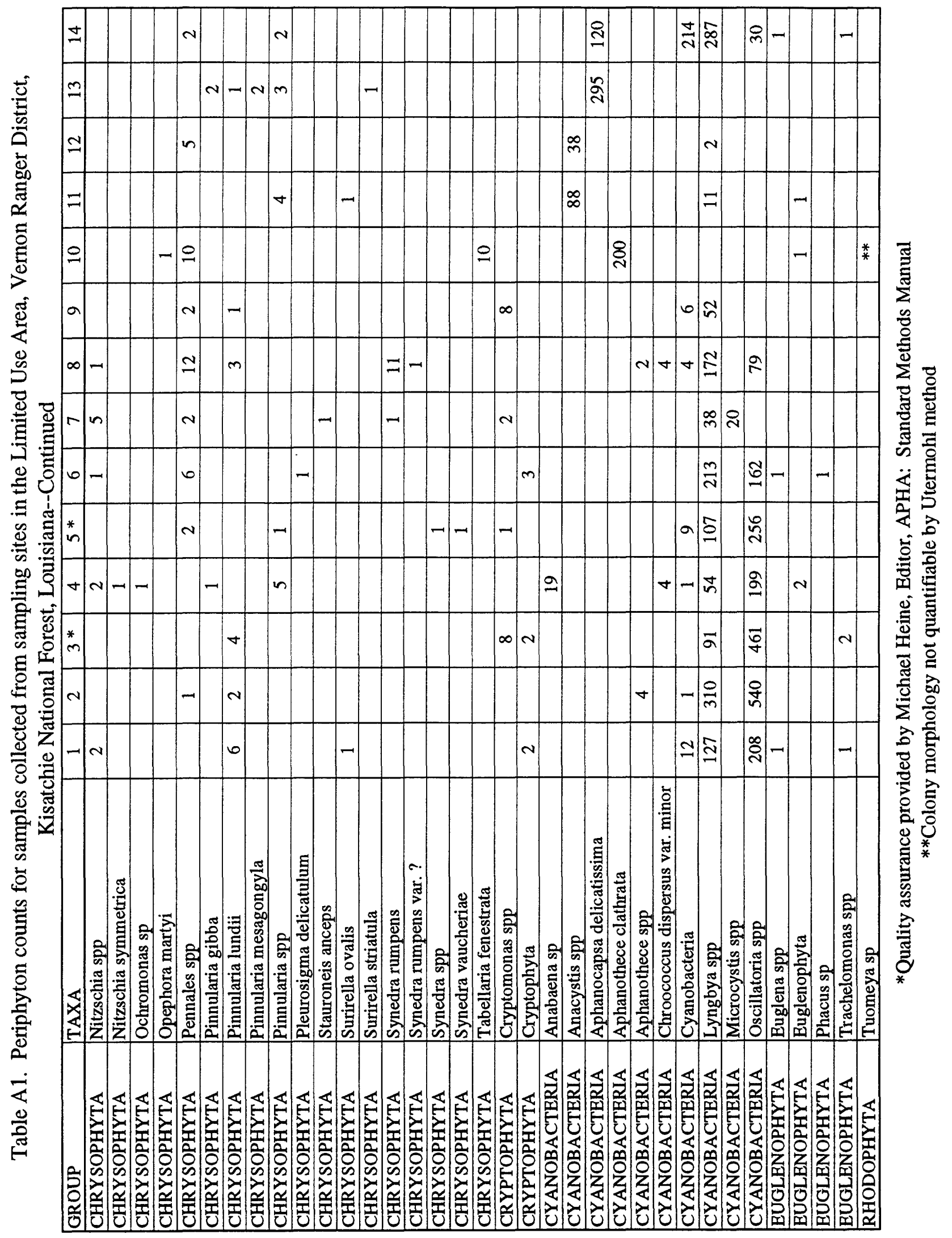




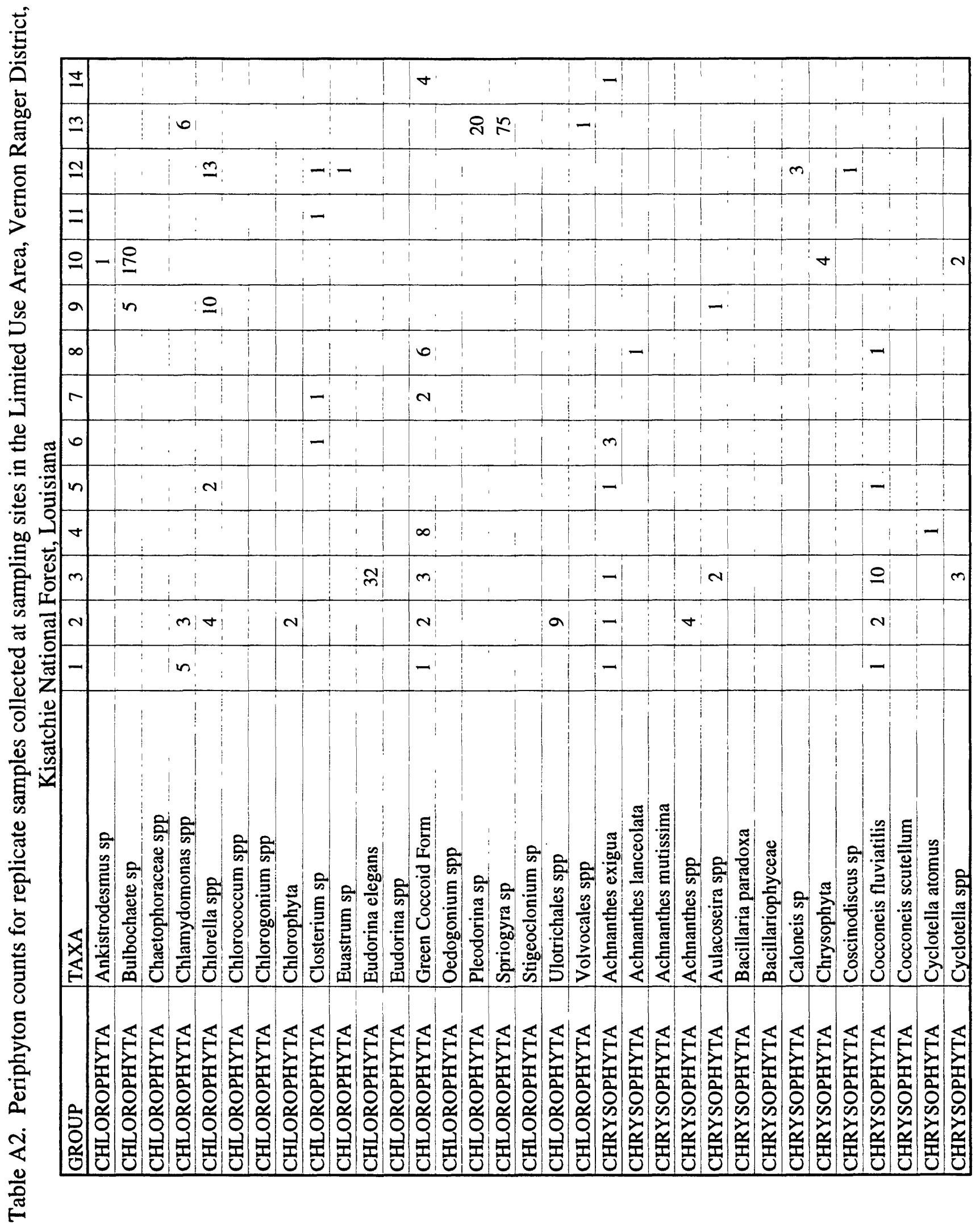




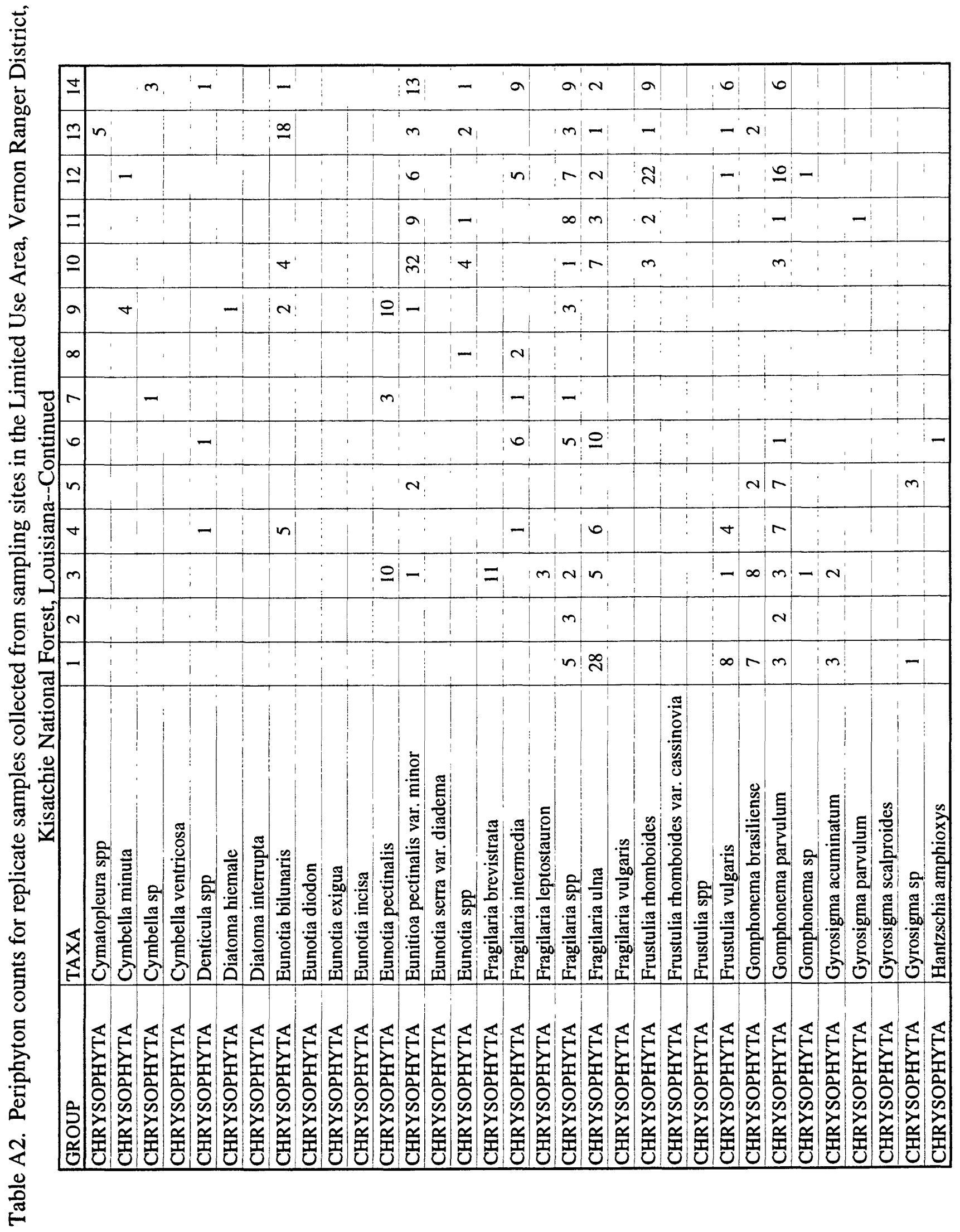




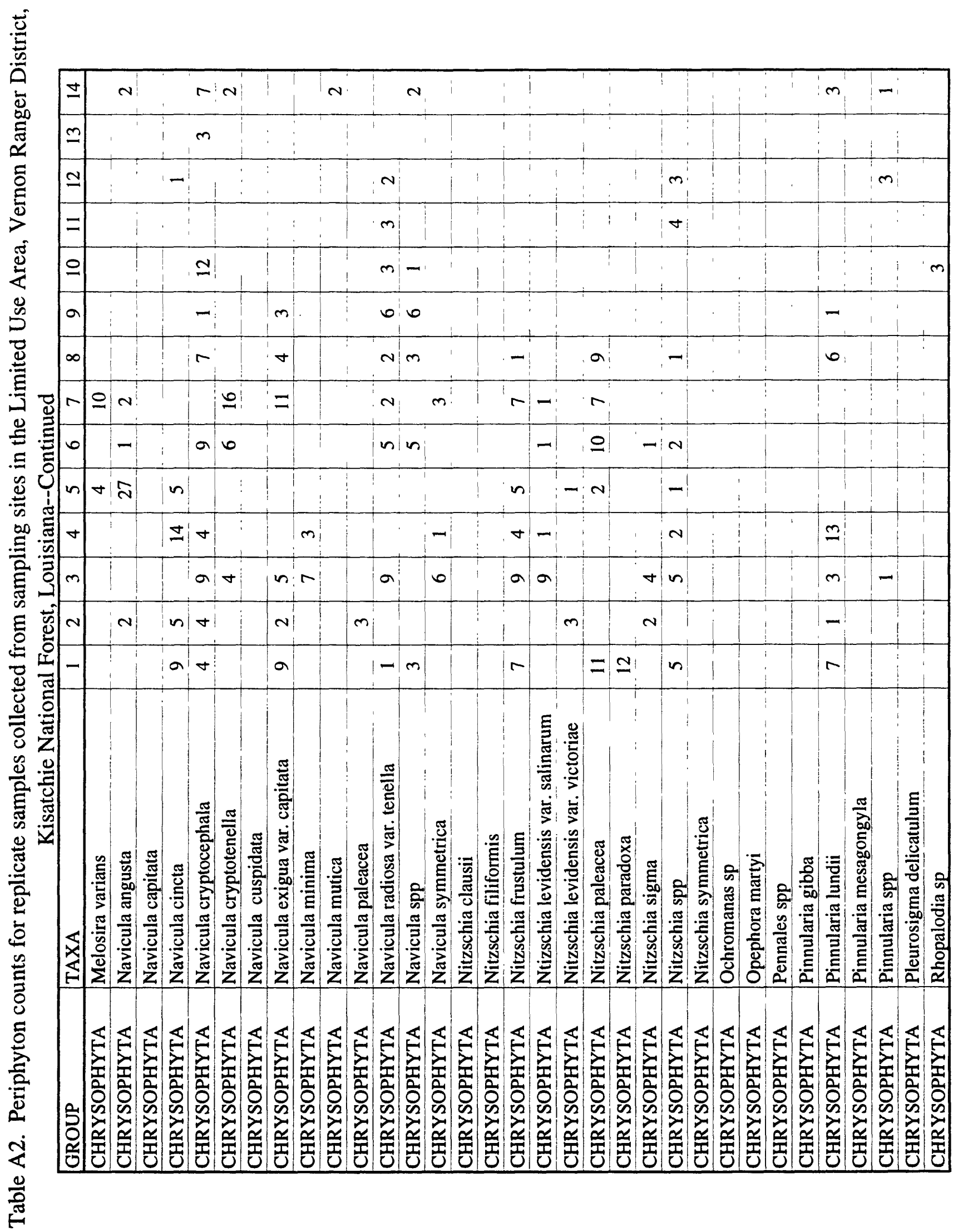




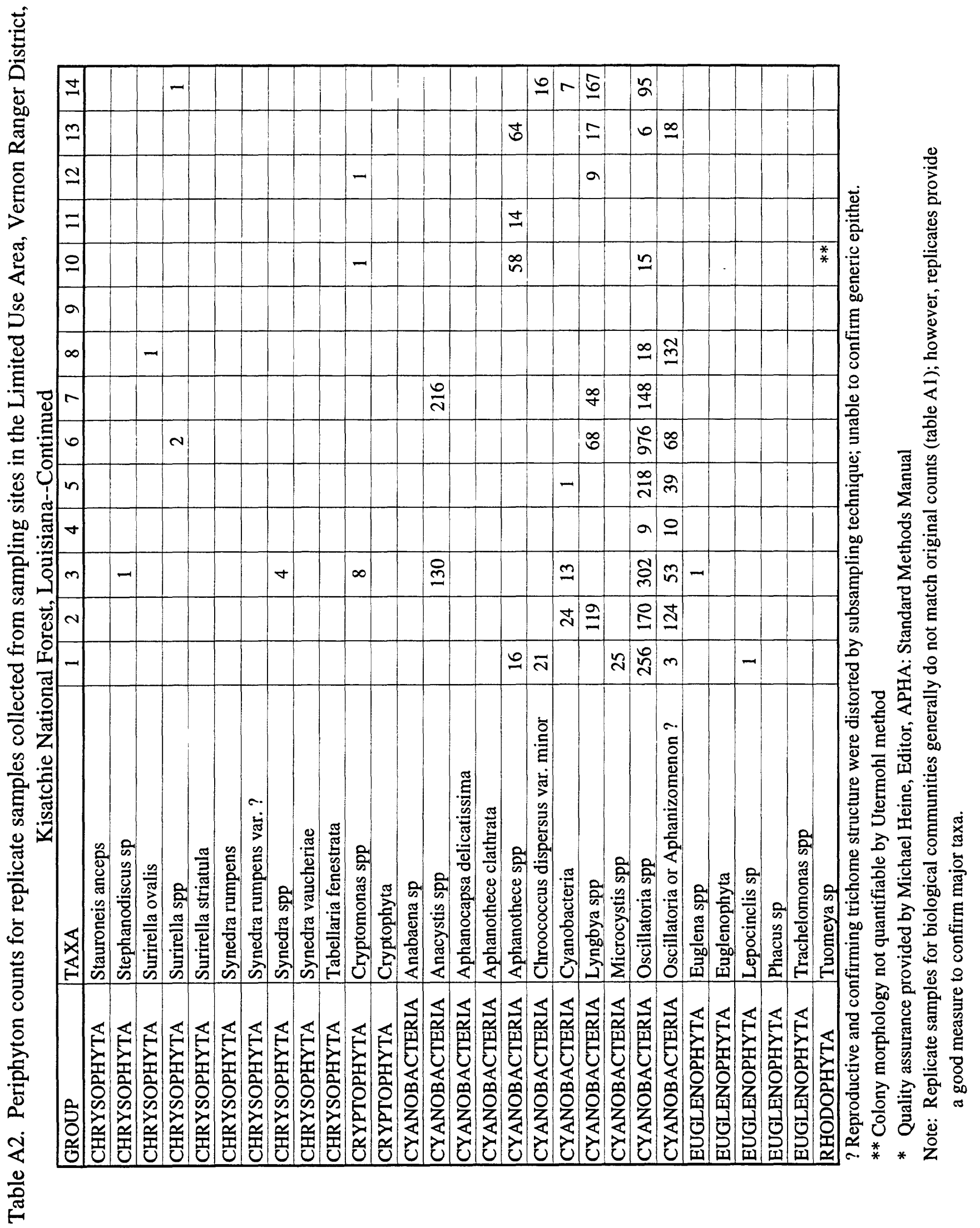




\title{
APPENDIX B:
}

\author{
ANALYSES OF FRESHWATER MUSSELS IN THE LIMITED USE \\ AREA, VERNON RANGER DISTRICT, KISATCHIE NATIONAL \\ FOREST, LOUISIANA
}

\section{CONTENTS}

Methods and Comments ..................................................................................... 122

Description of Freshwater Mussel Species Habitats................................................ 124

Selected References ............................................................................................ 128

Table B1. Mussels, exotic clams, and snails of Louisiana modified from AFS list Turgeon et al. 1988) and Hoeh's (1990) changes with possible unrecorded or historical residents and non-unionacean natives and exotic species

Table B2. Freshwater mussels and snails found at sampling sites in the Limited Usea Area, Vernon Ranger District, Kisatchie National Forest, Louisiana

Table B3. Mussels in headwater creeks of the Calcasieu River system from

Fort Polk, Peason Ridge, and the Kisatchie National Forest, Louisiana

Table B4. Other freshwater mussel species suspected of occurring in headwater creeks and larger creeks in the Vernon Ranger District, Kisatchie National Forest, Louisiana.

Table B5. Distribution of mussels in Louisiana streams in regards to provinces as they commonly occur in headwater streams.

Table B6. Mussels collected from Fort Polk, Kisatchie National Forest, and the Calcasieu drainages just downstream from the sites selected for this study. Station numbers correspond to those in the original text

\author{
PREPARED BY DR. MALCOLM F. VIDRINE \\ PROFESSOR OF BIOLOGY \\ DEPARTMENT OF BIOLOGY \\ LOUISIANA STATE UNIVERSITY AT EUNICE
}




\section{METHODS AND COMMENTS}

Fourteen stations were sampled for freshwater mussels, one station at each of fourteen sites designated by the United States Geological Service, from December, 1996, through January, 1997. The sampling consisted of nondestructive visual examination and identification each mussel in the stream bottom for a distance of 100 feet, 50 feet above and below a center line. The center was designated based upon the reasonable possibility of the occurrence of mussels. After examination, the mussels were replaced into the stream bottom in the same location and orientation in which they were found. Sampling field ribbon was placed on the center line. Table B1 lists the mussels and some snails known to occur in Louisiana. Table B2 lists the stations and mussels found in the 14 stations during this sampling period.

The following mussels were encountered in these samples were:
Lampsilis hydiana
Villosa lienosa
Fusconaia askewi
Toxolasma parvus
Obovaria jacksoniana
Strophitus subvexus
Tritogonia verrucosa
Uniomerus tetralasmus

The Asiatic clam, Corbicula fluminea, was a locally abundant foreign contaminant in many samples. Also the snail, Campeloma decisum, was found in the samples. The findings are tallied in table B2. A total of 1844 mollusks were examined and counted. Of these, 802 were freshwater mussels, 983 were Asiatic clams, and 59 were snails. However, other mussels are known to exist in these and nearby streams.

Table B3 lists the mussels reported from the various headwater creeks in the Calcasieu River system, which drain Fort Polk and the Vernon District of the Kisatchie National Forest. It is also likely that additional species, although rare in headwaters, occur in these creeks (table B4). Table B5 lists the distribution of mussels in Louisiana streams, in regards to provinces, as they commonly occur in headwater streams. Previous work by this author on stations downstream from these headwater creeks are provided in table B6. Because the headwater creeks are integral constituents of the Calcasieu River watershed, a discussion of the mussels occurring in the entire watershed is necessary.

Impacts upon headwater streams have an impact upon entire downstream drainage which is evident in freshwater mussels. Sedimentation and pollution are significant deleterious impositions upon mussel communities in the Calcasieu drainages. The headwaters of the Calcasieu have suffered less sedimentation than other streams in Louisiana because of the limited agriculture and, 
in part, because of the land use and management activities of the U. S. Army (Fort Polk) and the Forest Service (Kisatchie National Forest). Changes in management activities may change the nature of the streams and their mussel communities. The Calcasieu system contains the last major populations of several kinds of mussels that previously were abundant in the Sabine and Neches Rivers. Impoundment, sedimentation, and other factors have seriously decimated those populations (Howells et al. 1996). This increases the importance of the populations of mussels (and other animals and plants) in the Calcasieu River watershed, because they are relicts of a once much larger western Gulf ecosystem (Vidrine 1993). The close ties of the Calcasieu and Sabine watersheds is evident in their similarities in mussel communities.

The Calcasieu River system is one of the most interesting watersheds in the United States. It contains a unique assemblage of freshwater mussels that most closely resembles the assemblage previously found in the Sabine-Neches River system--a system that has sustained enormous decimation because of human use. Many of the better known mussel beds (locations) in that system are now devoid of mollusks (Howells et al. 1996). The Calcasieu River system, especially its headwaters, hosts a large, viable community of freshwater mussels (Vidrine 1993). The Calcasieu River remains for the most part in a near natural state. It has suffered in regions from paper mill wastes and sand mining, but it retains a diverse assemblage that is uniquely Western Gulf. The headwater streams have been studied in some detail, and large mussel populations exist and form rather diverse communities. The headwaters drain hilly, pineland regions, and these sandy streams occasionally suffer from sedimentation. The general absence of agriculture and urbanization on this river has provided for some of the most productive mussel habitat. The headwaters of this river may have been involved in stream capture with the Red River, Sabine River, and Bayou Teche headwaters (Vidrine 1993). Freshwater mussels include:

Pyganodon grandis

Strophitus subvexus

Amblema plicata

Quadrula quadrula

Quadrula pustulosa mortoni

Pleurobema riddelli

Uniomerus declivus

Glebula rotundata

Lampsilis hydiana

Leptodea fragilis

Obliquaria reflexa

Potamilus purpuratus

Toxolasma texasensis

Villosa lienosa
Utterbackia imbecillis

Arcidens confragosus

Plectomerus dombeyanus

Quadrula apiculata

Tritogonia verrucosa

Fusconaia askewi

Uniomerus tetralasmus

Lampsilis satur

Lampsilis teres

Ligumia subrostrata

Obovaria jacksoniana

Toxolasma parvus

Truncilla donaciformis 
The headwaters of the Calcasieu River contain 4 species new to science that are as yet undescribed:

Strophitus sp. (currently assigned to Strophitus subvexus)

Utterbackia sp. (currently assigned to Utterbackia imbecillis, but referred to Utterbackia sp. near. peggyae (Johnson) by R. Hoeh in Vidrine (1996c).

Obovaria sp. (currently assigned to Obovaria jacksoniana)

Toxolasma sp. (currently assigned to Toxolasma parvus).

With this many undescribed species, it is apparent that the river system assemblage needs re-evaluation. Several of these species are only known from this drainage and/or from one or two drainages which neighbor the Calcasieu River.

Freshwater mussels are the most endangered organisms, as a group, on the planet (Cushman 1995). The Louisiana Natural Heritage Program (Animals of Special Concern: January 1997) lists two of the mussels in the headwater creeks of Fort Polk and the Vernon District: Strophitus subvexus (ranked G1 and S?; also see Hart and 1993) and Pleurobema riddelli (ranked G2 and S2). Williams and others (1993) listed Obovaria jacksoniana and Pleurobema riddelli with special concern. The communities of freshwater mussels in the headwater creeks and the Calcasieu River watershed are unique and threatened. With the demise of all of the mussel communities in the rivers of southwestern Louisiana and southeastern Texas, the Calcasieu River system has become a refuge for this unique community of freshwater mussels.

\section{DESCRIPTION OF FRESHWATER MUSSEL SPECIES HABITATS}

Lampsilis hydiana--They are the most abundant freshwater mussel in the headwater creek of the Calcasieu River system, and thus the most abundant mussel species at Fort Polk. The mussels move about freely along the stream bottom, but are typically located along the edges of the streams, where they are buried leaving only the smallest part of the post-basal shell exposed. These mussels have obvious sexual dimorphism in their shells. Very little is known about their life cycle and glochidial hosts. The mantle in the postbasal region is pigmented and appears fish-like. The structure is more elaborate in females, and it is commonly seen in late spring and early summer in very shallow water wiggling like a fish when the marsupia are fully charged with mature glochidia (an aggressive mimicry). It is strongly suspected that fish attempting to eat this fish mimic obtain a mouthful of aggressive glochidia, which, in turn, encyst in the gill filaments of the host fish. Many similar mussel species undergo a week of encystment and metamorphosis followed by excystment by the newly-formed, larval (juvenile) mussel, which attaches to other mussel shells or debris by a thin, elongate byssus. Although these mussels can form aggregations (beds), they are more commonly scattered in the available habitat. They tend to move more than many other kinds of mussels, which assists them in orientating themselves in the stream, possibly, for best use of the mantle flaps. They usually occur in sandy bottoms, but they have been found in muddy bottoms in clear or silty streams. 
Villosa lienosa--These are the second most abundant mussels in the creeks of Fort Polk. However, in cases where sedimentation events occur, Fusconaia askewi will outnumber these mussels, because Villosa lienosa are sensitive to silt and sediment. They disappear from areas after depositional events, and it is common to find dead shells in areas of impact. Villosa lienosa resemble Lampsilis hydiana in many ways, but differ in specific ways worth mentioning. Whereas, Lampsilis hydiana has a fish-like mantle flap, Villosa lienosa has a mantle flap with melanistic finger-like projections, which, as a group, generally resemble hellgrammite. They are most commonly encountered buried in banks, like the Lampsilis hydiana, but will die quickly if taken out of the stream and held either out of water or in standing water. Lampsilis hydiana can withstand such removal with little loss of life. Villosa lienosa is uncommon in the lower reaches of the Calcasieu River, unlike Lampsilis hydiana (in fact, there are at least two other species of the genus Lampsilis downstream). The species, Villosa, is widely distributed along the Gulf Coast, north to Ohio, and contains a unique species of water mite. Villosa lienosa is restricted to sandy bottoms and clear streams.

Fusconaia askewi (formerly referred to as Fusconaia lananensis by this author and as currently assigned may include both species in the Calcasieu River system)--These mussels are different from the above two species in a great number of ways. First, they are gravid in the summer, while the previous two species are gravid in the late summer, winter, and spring. The male and female shells are identical. The eggs are scarlet in color, where Lampsilis and Villosa have eggs that are white to cream in color. No obvious mechanism for attracting fish is known. These mussels prefer the deeper part of the stream, and they will form small beds with clusters of individuals, which apparently move very little. They are very common in gravel. There may be two species involved, the second species is $F$. lananensis, and their separation is not clear (Howells $e t$ al. 1996). They are also common in the lower reaches of the Calcasieu River, where they can form fairly large beds with other species of mussels. These are restricted to the sandy, clear streams of the Calcasieu River system and westward into Texas; however, a single specimen has been found in Kisatchie Bayou, where Fusconaia flava is common.

Toxolasma sp. (currently assigned to Toxolasma parvus and formerly referred to as Carunculina parva)--These are very small mussels, which are often found in only a few centimeters of water near the edge of the creeks with sandy bottoms. The species in the creeks of Fort Polk is sexually dimorphic in shell forms. This dimorphism and its extremely small size suggests that it is a species new to science ( $R$. Hoeh, personal communication). Either it or a sister species occurs in Kisatchie Creek, a tributary of the Red River draining Peason Ridge. Both populations contain the same unique mite. Typically, Toxolasma parvus thrive in lakes; therefore, it is unique to small creeks in southwestern Louisiana. The post-basal mantle flap of the female is modified into a worm-like caruncle, which turns beet-red during the late spring and early summer. The two caruncles, one on either mantle, "wiggle" like "bloodworms" and attract fish, which, hypothetically, are lured into takng a mouthful of glochidia. This occurs in shallow water near the stream's edge. The much larger and often misunderstood Toxolasma texasensis is apparently not in the streams of the headwaters of the Calcasieu River, but may be found in ponds and lakes in the area. Very little is known of the biology of these species. 
Obovaria sp. (currently assigned to Obovaria jacksoniana and previously referred to as Obovaria castanea)--These mussels are abundant but scattered on sandbars, which are common downstream in the Calcasieu River. The mussels appear to prefer stable areas of clear streams with shifting sand. It is also found in one location in Missouri (Oesch 1984), and it is common in several streams in North Central Louisiana, including the Dugdemona River and Kisatchie Bayou. The type material for this species is described from eastern Louisiana and Mississippi. The western populations are larger in size. They are probably a new and undescribed species. The post-basal mantle flap is melanistic with a thin white line along the edge. This structure undulates and appears to vaguely resemble a swimming oligocheate. It may also serve to lure host fish for an infective meal of larvae. These mussels are not abundant in the headwater creeks of the Calcasieu River system. Nothing is known of the biology of these mussels.

Tritogonia verrucosa--Locally, these mussels are common in small, medium, and large streams. They were only sporadically found in Whiskey Chitto and Birds Creeks. Male and female shells are obviously different. Nothing is known of the biology of these mussels. These are the largest mussels encountered in the headwater creeks. They may occur at any location in the bottom of the stream and in any bottom type. The species is distributed throughout most of eastern North America.

Uniomerus tetralasmus (including records for Uniomerus declivus)--Two distinctly different species of this genus is a popular conception; however, they are very variable not only in morphology but also in habitat preference, occurring in ponds, lakes, creeks, and rivers. Also, they are reported to live out of water for more than a month while stranded on bars during low water. The presently accepted method used in separation of the species may be inadequate. They are locally abundant in the streams of Fort Polk and the Vernon Ranger District, where they usually occur anywhere in the stream bottom and in any bottom type, and are sometimes locally abundant. The species is distributed throughout most of eastern North America.

Strophitus sp. (currently assigned to Strophitus subvexus)--These mussels are a new and undescribed species unique to the Calcasieu River system and may have occurred historically in the Sabine River system. They are usually in the bottom of the stream in the deepest water, where current is obvious. They occur in Drakes, Whiskey Chitto, Birds, and Tenmile Creeks in the Fort Polk area and in the Vernon Ranger District. It has a unique water mite parasitizing it. Nothing is known of their biology. It is currently globally ranked as rare.

Pleurobema riddelli--These mussels are poorly understood. Historically, they were known under several different names from the Red River and Bayou Teche systems; however, they have all but disappeared from those systems (Vidrine 1993). They once were abundant in the Neches River system, but are no longer found (Howells et al. 1996). Few specimens have been encountered in the Calcasieu River system. A single specimen was found in 1989 in Drakes Creek on Fort Polk. None have been found since, and they are globally ranked as rare. They are often found mixed in with Fusconaia spp. forming beds in sand or small gravel bottoms. Nothing is known of their biology. It shares a unique mite with the Pleurobema spp. in the eastern Gulf drainages. 
Utterbackia sp. (currently assigned to Utterbackia imbecillis)--These mussels are a new and undescribed species, which is closely related to Utterbackia peggyae from Florida (Randy Hoeh, personal communication). It is abundant in the pool in Drakes Creek under the bridge on Lookout Road. It also was found in 1992 in Drakes Creek on the Vernon District. This is the only stream in Louisiana known to contain this species. A similar species was found in at least one pond in Texas (Howells et al. 1996). This is an exceedingly rare species. Nothing of its biology is known. It apparently is restricted to pool areas with silt in sandy streams. It has a unique mite.

Pyganodon grandis (formerly referred to as Anodonta grandis)--This mussel was also found in Drakes Creek. A single specimen was found in the pool under the Lookout Road bridge. This is, however, a very common mussel in lakes and lenthic waterways. It prefers mud and silt, and can attain a very large size. It should be a resident of ponds and lakes in the area. It has a unique mite.

Campeloma decisum--These snails are common throughout the Mississippi Interior Basin, where organically enriched streams may contain enormous populations. It has a unique mite.

Asiatic clams were the most common mollusks found in these samples. These clams can attain astronomical numbers in watersheds because they reproduce using veliger (free-swimming, nonparasitic) larvae. They are locally abundant in numerous localities not only in Louisiana, but also throughout the United States.

As evidenced with dragonflies (Vidrine 1988) and mussels (Vidrine 1993), there are a number of species and sibling species which are found in both eastern and western Louisiana (eastern Gulf and western Gulf regions). Hypothetically, the population and species separation between Mississippi and Atchafalaya floodways occurred during and since the Mississippi Embayment. Mussel examples include western species verses eastern species (see Table B5):

Pleurobema riddelli vs Pleurobema beadleanum

Lampsilis satur vs Lampsilis ornata

Fusconaia askewi vs Fusconaia cerina

Quadrula p. mortoni vs Quadrula refulgens

Obovaria sp. vs Obovaria jacksoniana

Strophitus sp. vs Strophitus subvexus

Utterbackia sp. vs Utterbackia peggyae

Toxolasma sp. vs Toxolasma parvus

It is both interesting and important to note that no mussels were found in Little Sixmile Creek. The bottom of this creek contained sand and gravel with a flora that was similar to East Fork and West Fork Sixmile Creek and notably different from Birds Creek. The plant species were more hydric and more "baygallish", with indicator woody species like Itea virginica, Halesia diptera, Hypericum prolificum, Nyssa sylvatica, and Smilax laurifolia, and herbaceous species like Panicum dichotomum and Elephantopus spp. The plants in the stream were even more obvi- 
ous and included Fontinalis spp., Sparganium americanum, and the red alga Batrachospermum spp. (Charles Allen, personal communication). It appears that water-quality of streams with this flora have a distinctively different chemistry. As distinctive as the flora is, the mussel community is distinctive in its absence. This indicates that the freshwater mussels and possible their host fish find these streams poor habitat or otherwise adversely affecting their viability.

Apparently, Sixmile Creek habitat is less adverse to mussels further downstream, as evidenced by the following collections. In 1992, Sixmile Creek at LA Highway 458 was sampled, and 164 mussels were found in 50 meters of stream. The majority (104) were Fusconaia askewi. Other mussels found were Villosa lienosa, Obovaria jacksoniana, Lampsilis hydiana, and Toxolasma parvus. Most of these mussels were clumped in a single bed (Vidrine 1992). In 1994, Sixmile Creek at LA Highway 113 was sampled. Ninety-seven mussels were found in approximately 600 meters of stream. The majority were Fusconaia askewi. Other mussels found were Villosa lienosa, Lampsilis hydiana, and Toxolasma parvus. Most of these mussels were clumped in a single bed (Radian Corporation 1995).

\section{SELECTED REFERENCES}

Burch, J. B. 1975a. Freshwater sphaeriacean clams (Mollusca: Pelecypoda) of North America. Malacological Pub., 96 pp.

Burch, J. B. 1975b. Freshwater unionacean clams (Mollusca: Pelecypoda) of North America. Malacological Pub., Hamburg, Michigan. 204 pp.

Burch, J. B. 1989. North American freshwater snails. Malacological Publications (Hamburg, MI). 365 pp.

Cushman, John H. Jr. 1995. Freshwater mussels face mass extinction. N. Y. Times News Service. 1 page.

Cummings, K. S. and C. A. Mayer. 1992. Field guide to freshwater mussels of the Midwest. Illinois Nat. Hist. Surv. Manual No. 5. 194 pp.

Fuller, S. L. H. 1974. Clams and mussels (Mollusca: Bivalvia). pp. 215-273. In: C. W. Hart and S. L. H. Fuller (eds.). Pollution ecology of freshwater invertebrates. Academic Press, New York. 389 pp.

Fuller, S. L. H. 1978. Final Report: Fresh-water mussels (Mollusca: Bivalvia: Unionidae) of the upper Mississippi River: observations at selected sites within the 9-foot channel navigation project on behalf of the United States Army Corps of Engineers. The Acad. of Nat. Sci. Phil., Philadelphia, Pennsylvania. 401 pages.

Hoeh, W. R. 1990. Phylogenetic relationships among eastern North American Anodonta (Bivalvia: Unionidae). Malacological Review 23: 63-82. 
Howells, R. G., R. W. Neck, and H. D. Murray. 1996. Freshwater mussels of Texas. University of Texas Press (Austin, TX). iv +218 pp.

Hart, B. L. and G. D. Lester. 1993. Natural community and sensitive species assessment on Fort Polk Military Reservation, Louisiana. Louisiana Department of Wildlife and Fisheries and The Nature Conservancy. Submitted to Dept. of the Army Corps of Engineers, Memphis, Tennessee.

Oesch, R. D. 1984. Missouri Naiades: A guide to the mussels of Missouri. Missouri Department of Conservation, Jefferson City, MO. pp. i-vii + 1-270.

Radian Corporation. 1995. Freshwater Mussel and Stream Sediment Study (Part II Environmental Assessment) Joint Readiness Training Center and Fort Polk. Presented to: JRTC and Fort Polk, Louisiana and U. S. Army Corps of Engineers, Kansas City District, Kansas City, Missouri.

Roback, S. S., D. J. Bereza and M. F. Vidrine. 1980. Description of an Ablabesmyia (Diptera: Chironomidae: Tanypodinae) symbiont of unionid fresh-water mussels (Mollusca: Bivalvia: Unionacea), with notes on its biology and zoogeography. Trans. Amer. Entomol. Soc. 105: 577-619.

Turgeon, D. D., A. E. Bogan, E. V. Coan, W. K. Emerson, W. G. Lyons, W. L. Pratt, C. F. E. Roper, A. Scheltema, F. G. Thompson, and J. D. Williams. 1988. Common and scientific names of aquatic invertebrates from the United States and Canada: Mollusks. American Fisheries Society Special Publication 16: 1-277 (Unionoida, pp. 28-34).

U. S. Fish and Wildlife Service. 1992. Endangered and threatened wildlife and plants. U. S. Government Printing Office, Washington D. C. 13 pp.

Vidrine, M. F. 1985. Fresh-water mussels (Unionacea) of Louisiana; a zoogeographical checklist of post-1890 records. The Louisiana Environmental Professional 2 (1): 50-59.

Vidrine, M. F. 1988a. An inventory of flying insects (dragonflies, damselflies and butterflies) at Fort Polk. Contract No. DAKF2489M0538. 6 pages + slide show and collection. Submitted to: Steve Parris, DEH ENRMD BLDG 2501, Fort Polk, Louisiana 71459.

Vidrine, M. F. 1988b. An inventory of the freshwater mussels of Fort Polk and Peason Ridge. Contract No. DAKF2489M0595. 4 pages +4 tables +2 appendices. Submitted to: Steve Parris, DEH ENRMD BLDG 2501, Fort Polk, Louisiana 71459.

Vidrine, M. F. 1989a. A summary of the mollusk-mite associations of Louisiana and adjacent waters. The Louisiana Environmental Professional 6 (1): 30-63.

Vidrine, M. F. 1989b. Status of fresh-water mussel communities in five streams along Lookout Road at Fort Polk. Contract no. DAKF2489M5645. 4 pages +22 tables. Submitted to: Steve Parris, DEH ENRMD BLDG 2501, Fort Polk, Louisiana 71459.

Vidrine, M. F. 1990. Field survey of selected sub-watershed of Comrade Creek to ascertain the presence of Mollusca. Contract no. DACA8890M0663. 3 pages. Submitted to: Eunice Vachta, U. S. Army Construction Engineering Laboratory, P. O. Box 4005, Champaign, Illinois 61824-4005. 
Vidrine, M. F. 1991. Environmental assessment of Ranges 36 and 37 and associated portions of West Fork Six Mile Creek. Contract No. DACA3991M3522. Submitted to: Gayle Albritton, U. S. Army Engineers Waterways Experiment Station, 3909 Hallsferry Road, Vicksburg, Mississippi 39180-6199.

Vidrine, M. F. 1992. Status of fresh-water mussel communities in five streams along Lookout Road at Fort Polk and evaluation of West Fork Six Mile Creek mussel communities. Contract No. 50-7217-2-63. Submitted to: Charles Phillips, U. S. D. A., Soil Conservation Service, 3737 Government Street, Alexandria, Louisiana 71302.

Vidrine, M. F. 1993. The historical distributions of freshwater mussels in Louisiana. Gail Q. Vidrine Collectables (Eunice, LA). 225 pp.

Vidrine, M. F. 1995. River survey for freshwater mollusks of Bayou Bartholomew in northeastern Louisiana. 15 January 1995. pp. v+114 + 9 color plates. Submitted to: Stephen Shively, Natural Heritage Program, Dept. of Wildlife and Fisheries, P. O. Box 98000, Baton Rouge, LA 708989000.

Vidrine, M. F. 1996a. River survey for freshwater mollusks of Tensas River system in northeastern Louisiana. pp. vi $+135+10$ color plates. Submitted to: Stephen Shively, Natural Heritage Program, Dept. of Wildlife and Fisheries, P. O. Box 98000, Baton Rouge, LA 70898-9000.

Vidrine, M. F. 1996b. North American Najadicola and Unionicola: Photomicrographs. Gail Q. Vidrine Collectibles (Eunice, LA). xiv +205 pages.

Vidrine, M. F. 1996c. North American Najadicola and Unionicola: Collections and Communities. Gail Q. Vidrine Collectibles (Eunice, LA). vi + 259 pages.

Vidrine, M. F. 1996d. North American Najadicola and Unionicola: Systematics and Coevolution. Gail Q. Vidrine Collectibles (Eunice, LA). vi + 145 pages.

Vidrine, M. F. 1996e. North American Najadicola and Unionicola: Diagnoses and Distributions. Gail Q. Vidrine Collectibles (Eunice, LA). vi + 355 pages.

Vidrine, M. F. 1996f. Najadicola and Unionicola: I. Diagnoses of Genera and Subgenera. II. Key. III. List of Reported Hosts. Gail Q. Vidrine Collectibles (Eunice, LA). vi + 180 pages.

Warren, R. E. 1991. Freshwater mussels as paleoenvironmental indicators: A quantitative approach to assemblage analysis. In: J. R. Purdue, W. E. Klippel, and B. W. Styles, Editors. Beamers, Bobwhites, and Blue-points: Tributes to the Career of Paul W. Parmalee. Illinois State Museum Scientific Papers, Vol. 23, Springfield. pp. 23-66.

Watters, G. T. 1994. An annotated bibliography of the reproduction and propagation of the Unionoidea (primarily of North America). Ohio Biol. Surv. Misc. Contr. No. 1: vi + 158 pages.

Williams, J. D., M. L. Warren Jr., K. S. Cummings, J. L. Harris, and R. J. Neves. 1993. Conservation status of freshwater mussels of the United States and Canada. Fisheries (Bethesda) 18 (9): 6-22. 
Table B1. Mussels, exotic clams, and snails of Louisiana modified from AFS list (Turgeon et al. 1988) and Hoeh's (1990) changes with possible unrecorded or historical residents and non-unionacean natives and exotic species

Scientific Name

Common Name

Margaritiferinae

Margaritifera hembeli (Conrad, 1838)

Louisiana pearlshell

Unionidae

Anodontinae

Pyganodon grandis (Say, 1829)

Utterbackia imbecillis (Say, 1829)

Anodonta suborbiculata Say, 1831

Anodonta woodiana (Lea)

Anodontoides radiatus (Conrad, 1834)

Strophitus subvexus (Conrad, 1834)

Strophitus undulatus (Say, 1817)

Arcidens confragosus (Say, 1829)

Lasmigona complanata (Barnes, 1823)

Ambleminae

Amblemini

Amblema plicata (Say, 1817)

Megalonaias nervosa (Rafinesque, 1820)

Plectomerus dombeyanus (Valenciennes, 1827)

Quadrula pustulosa pustulosa (Lea, 1831)

Quadrula pustulosa mortoni (Conrad, 1835)

Quadrula refulgens (Lea, 1868)

Quadrula nodulata (Rafinesque, 1820)

Quadrula nobilis (Conrad 1854)

Quadrula apiculata (Say, 1829)

Quadrula quadrula (Rafinesque, 1820)

Quadrula cylindrica (Say, 1817)

Quadrula metanevra (Rafinesque, 1820)

Tritogonia verrucosa (Rafinesque, 1820)

Pleurobemini

Pleurobema rubrum (Rafinesque, 1820)

Pleurobema beadleanum (Lea, 1861)

Pleurobema riddelli (Lea, 1861)

Elliptio crassidens (Lamarck, 1819)

Elliptio dilatata (Rafinesque, 1820)

Fusconaia askewi (Marsh, 1896)

Fusconaia cerina (Conrad, 1838)

Fusconaia flava (Rafinesque, 1820)

giant floater

paper pondshell

flat floater

Asian floater

rayed creekshell

southern creekmussel

squawfoot

rock-pocketbook

white heelsplitter

threeridge

washboard

bankclimber

pimpleback

western pimpleback

purple pimpleback

wartyback

Gulf Mapleleaf

southern mapleleaf

mapleleaf

rabbitsfoot

monkeyface

pistolgrip

pyramid pigtoe

Mississippi pigtoe

Louisiana pigtoe

elephant ear

spike

Texas pigtoe

Gulf pigtoe

Wabash pigtoe 
Table B1. Mussels, exotic clams, and snails of Louisiana modified from AFS list (Turgeon et al. 1988) and Hoeh's (1990) changes with possible unrecorded or historical residents and non-unionacean natives and exotic species--Continued

Scientific Name

Common Name

Pleurobemini (continued)

Fusconaia ebena (Lea, 1831)

Uniomerus tetralasmus (Say, 1831)

ebonyshell

Uniomerus declivus (Say, 1831)

pondhorn

Lampsilini

tapered pondhorn

Actinonaias ligamentina (Lamarck, 1819)

Cyprogenia aberti (Conrad, 1850)

Ellipsaria lineolata (Rafinesque, 1820)

Glebula rotundata (Lamarck, 1819)

Lampsilis abrupta (Say, 1831)

Lampsilis cardium (Rafinesque, 1820)

Lampsilis satur (Lea, 1852)

Lampsilis ornata (Conrad, 1835)

Lampsilis siliquoidea (Barnes, 1823)

Lampsilis hydiana (Lea, 1838)

Lampsilis claibornensis (Lea, 1838)

Lampsilis teres (Rafinesque, 1820)

Ligumia recta (Lamarck, 1819)

Ligumia subrostrata (Say, 1831)

Leptodea fragilis (Rafinesque, 1820)

Potamilus amphichaenus (Frierson, 1898)

Potamilus inflatus (Lea, 1831)

Potamilus ohiensis (Rafinesque, 1820)

Potamilus capax (Green, 1832)

Potamilus purpuratus (Lamarck, 1819)

Ptychobranchus occidentalis (Conrad, 1836)

Toxolasma parvus (Barnes, 1823)

Toxolasma texasensis (Lea, 1857)

Obliquaria reflexa (Rafinesque, 1820)

Obovaria jacksoniana (Frierson, 1912)

Obovaria olivaria (Rafinesque, 1820)

Obovaria unicolor (Lea, 1845)

Truncilla donaciformis (Lea, 1828)

Truncilla truncata (Rafinesque, 1820)

Villosa lienosa (Conrad, 1834)

Villosa vibex (Conrad, 1834)

mucket

western fanshell

butterfly

round pearlshell

pink mucket

plain pocketbook

sandbank pocketbook

southern pocketbook

fatmucket

Louisiana fatmucket

southern fatmucket

yellow sandshell

black sandshell

pondmussel

fragile papershell

Texas heelsplitter

inflated heelsplitter

pink papershell

fat pocketbook

bleufer

Ouachita kidneyshell

lilliput

Texas lilliput

threehorn wartyback

southern hickorynut

hickorynut

Alabama hickorynut

fawnsfoot

deertoe

little spectaclecase

southern rainbow 
Table B1. Mussels, exotic clams, and snails of Louisiana modified from AFS list (Turgeon et al. 1988 ) and Hoeh's (1990) changes with possible unrecorded or historical residents and non-unionacean natives and exotic species--Continued

Scientific Name

Common Name

Exotic clams

Corbicula fluminea (Muller)

Dreissena polymorpha (Pallas)

Snails of Interest

Viviparidae

Campeloma Rafinesque 1819

Campeloma decisum (Say, 1816)

Viviparus Montfort 1810

Viviparus subpurpureus (Say, 1829)

Viviparus intertextus (Say, 1829)

Pleuroceridae

Pleurocera Rafinesque 1818

Pleurocera canaliculatum canaliculatum (Say, 1821) 
Table B2. Freshwater mussels and snails found at sampling sites in the Limited Usea Area, Vernon Ranger District, Kisatchie National Forest, Louisiana

\begin{tabular}{|c|c|c|c|c|c|c|c|c|c|c|c|c|c|c|c|}
\hline \multirow[t]{2}{*}{ Mollusks } & \multicolumn{14}{|c|}{ Stations } & \multirow[t]{2}{*}{ Totals } \\
\hline & 1 & 2 & 3 & 4 & 5 & 6 & 7 & 8 & 9 & 10 & 11 & 12 & 13 & 14 & \\
\hline Lampsilis hydiana & 8 & 3 & 72 & 117 & 11 & 0 & 0 & 8 & 114 & 0 & 0 & 0 & 0 & 0 & 333 \\
\hline Villosa lienosa & 3 & 0 & 13 & 54 & 10 & 0 & 1 & 7 & 31 & 0 & 0 & 1 & 0 & 0 & 120 \\
\hline Fusconaia askewi & 1 & 1 & 44 & 53 & 0 & 0 & 4 & 30 & 34 & 0 & 0 & 0 & 0 & 0 & 167 \\
\hline Toxolasma parvus & 0 & 0 & 8 & 93 & 5 & 0 & 0 & 1 & 39 & 0 & 0 & 0 & 0 & 0 & 146 \\
\hline Obovaria jacksoniana & 0 & 0 & 1 & 5 & 0 & 0 & 2 & 8 & 0 & 0 & 0 & 0 & 0 & 0 & 16 \\
\hline Strophitus subvexus & 0 & 0 & 0 & 0 & 0 & 0 & 0 & 1 & 1 & 0 & 0 & 0 & 0 & 0 & 2 \\
\hline Tritogonia verrucosa & 0 & 0 & 0 & 0 & 0 & 0 & 0 & 0 & 1 & 0 & 0 & 0 & 0 & 0 & 1 \\
\hline Uniomerus tetralasmus & 6 & 0 & 7 & 3 & 1 & 0 & 0 & 0 & 0 & 0 & 0 & 0 & 0 & 0 & 17 \\
\hline Corbicula fluminea & 232 & 0 & 195 & 226 & 23 & 27 & 78 & 88 & 114 & 0 & 0 & 0 & 0 & 0 & 983 \\
\hline Campeloma decisum & 0 & 0 & 9 & 10 & 0 & 7 & 20 & 7 & 6 & 0 & 0 & 0 & 0 & 0 & 59 \\
\hline Totals & 250 & 4 & 349 & 561 & 50 & 34 & 105 & 150 & 340 & 0 & 0 & 1 & 0 & 0 & 844 \\
\hline
\end{tabular}

\section{Stations*}

1. Bundick Creek $\sim 100 \mathrm{~m}$ upstream from bridge on Forest Service Road 422 and near entrance of Yoke Creek. Sampled December 23, 1996.

2. Bundick Creek at Forest Service Road $410 \sim 50 \mathrm{~m}$ upstream from the bridge. Sampled December 23, 1996.

3. Drakes Creek at Forest Service Road $421 \sim 50 \mathrm{~m}$ upstream from the bridge. Sampled December 23, 1996.

4. Drakes Creek at LA Hwy $10 \sim 100 \mathrm{~m}$ downstream from the bridge. Sampled December 23, 1996.

5. Drakes Creek at Forest Service $402 \sim 50 \mathrm{~m}$ upstream from the bridge. Sampled December 23, 1996.

6. Whiskey Chitto Creek at Lookout Road $\sim 100 \mathrm{~m}$ downstream from the bridge. Sampled December 24, 1996.

7. Whiskey Chitto Creek at Ray Gill Road $\sim 50 \mathrm{~m}$ upstream from the bridge. Sampled December 23, 1996.

8. Whiskey Chitto Creek at old Railroad bed (road) $\sim 100 \mathrm{~m}$ upstream from the washed out bridge (site is $~ 0.67$ map miles due south of LA 10 just west of Cravens). Sampled December 24, 1996.

9. Birds Creek at Lookout Road $\sim 50$ m downstream from the bridge. Sampled December 22, 1996.

10. Little Sixmile Creek just south of Kisatchie Forest line at Forest Service Road $421 \sim 30 \mathrm{~m}$ downstream from the bridge. Sampled December 22, 1996.

11. West Fork Sixmile Creek at Lookout Road $\sim 50 \mathrm{~m}$ downstream from the bridge. Sampled December 22, 1996.

12. West Fork Sixmile Creek due west of Fullerton Lake. Sampled December 22, 1996.

13. East Fork Sixmile Creek at Lookout Road $\sim 50 \mathrm{~m}$ downstream from the bridge. Sampled December 22, 1996.

14. East Fork Sixmile Creek at Forest Service Road 412 near Oak Grove Church $\sim 50 \mathrm{~m}$ upstream from the bridge.

*At each station the water level was up from 0.5 to 1.5 feet from previous work. The increase in water levels was more apparent in the larger streams. 
Table B3. Mussels in headwater creeks of the Calcasieu River system from Fort Polk, Peason Ridge, and the Kisatchie National Forest, Louisiana

\begin{tabular}{|c|c|c|c|c|c|c|c|c|c|c|}
\hline \multirow[t]{2}{*}{ Mussels } & \multicolumn{10}{|c|}{ Creeks. } \\
\hline & $\mathrm{BC}$ & DC & WC & $\mathrm{BiC}$ & LS & WF & $\mathrm{EF}$ & BB & $\mathrm{TC}$ & $\mathrm{CC}$ \\
\hline Lampsilis hydiana & $\mathrm{x}$ & $\mathrm{x}$ & $\mathrm{x}$ & $\mathrm{x}$ & & $x$ & $\mathrm{x}$ & $\mathrm{x}$ & $\mathrm{x}$ & $\mathrm{x}$ \\
\hline Villosa lienosa & $\mathrm{x}$ & $\mathrm{x}$ & $\mathrm{x}$ & $\mathrm{x}$ & & $\mathrm{x}$ & $\mathrm{x}^{*}$ & $\mathrm{x}$ & $\mathrm{x}$ & $\mathrm{x}$ \\
\hline Fusconaia askewi & $\mathrm{x}$ & $\mathrm{x}$ & $\mathrm{x}$ & $\mathrm{x}$ & & $\mathrm{x}^{*}$ & $\mathrm{x}$ & $\mathrm{x}$ & $\mathrm{x}$ & $\mathrm{x}$ \\
\hline Toxolasma parvus & & $\mathrm{x}$ & $\mathrm{x}$ & $\mathrm{x}$ & & $\mathrm{x}$ & & $\mathrm{x}$ & $\mathrm{x}$ & $x$ \\
\hline Uniomerus tetralasmus & $\mathrm{x}$ & $\mathrm{x}$ & $\mathrm{x}$ & $\mathrm{x}$ & & & & & $\mathrm{x}$ & \\
\hline Obovaria jacksoniana & & $\mathrm{x}$ & $\mathrm{x}$ & $\mathrm{x}$ & & & & & & $\mathrm{x}$ \\
\hline Strophitus subvexus & & $\mathrm{x}$ & $\mathrm{x}$ & $\mathrm{x}$ & & & & & $\mathrm{x}$ & \\
\hline Utterbackia sp. & & $\mathrm{x}$ & & & & & & & & \\
\hline Pyganodon grandis & & $\mathrm{x}$ & & & & & & & & \\
\hline Pleurobema riddelli & & $\mathrm{x}$ & & & & & & & & \\
\hline Tritogonia verrucosa & & & $\mathbf{x}$ & $x$ & & & & & & \\
\hline
\end{tabular}

* Records were in 1996 not distant from 1992 transplant sites!

List of Creeks:

Bundick Creek--BC

Drakes Creek--DC

Whiskey Chitto--WC

Birds Creek--BiC

Little Sixmile Creek--LS

West Fork Sixmile Creek--WF

East Fork Sixmile Creek--EF

Big Brushy Creek--BB

Tenmile Creek--TC

Comrade Creek--CC 
Table B4. Other freshwater mussel species suspected of occurring in headwater creeks and larger creeks in the Vernon Ranger District, Kisatchie National Forest, Louisiana

Quadrula pustulosa mortoni

Lampsilis teres

Lampsilis satur

Potamilus purpuratus

Leptodea fragilis

Amblema plicata

Plectomerus dombeyanus

Glebula rotundata

Uniomerus declivus

Ligumia subrostrata

Obliquaria reflexa 
Table B5. Distribution of mussels in Louisiana streams in regards to provinces as they commonly occur in headwater streams

Species

Margaritifera hembeli

Anodontoides radiatus

Strophitus subvexus

Strophitus undulatus

Quadrula p. pustulosa

Quadrula p. mortoni

Quadrula refulgens

Tritogonia verrucosa

Pleurobema beadleanum

Pleurobema rubrum

Pleurobema riddelli

Elliptio crassidens

Elliptio dilatata

Fusconaia flava

Fusconaia askewi

Fusconaia cerina

Uniomerus tetralasmus

Lampsilis ornata

Lampsilis satur

Lampsilis hydiana

Lampsilis claibornensis

Lampsilis teres

Ligumia subrostrata

Obovaria jacksoniana

Obovaria unicolor

Potamilus purpuratus

Toxolasma parvus

Toxolasma texasensis

Truncilla donaciformis

Truncilla truncata

Villosa lienosa

Villosa vibex
W. Gulf

$\mathrm{x}$

$\mathrm{x}$

X

$\mathrm{x}$

X

X

$\mathrm{x}$

$\mathrm{x}$

$\mathrm{x}$

$\mathrm{x}$

$\mathrm{x}$

$\mathrm{X}$

$\mathrm{X}$

$\mathrm{x}$

$\mathrm{X}$

$\mathrm{x}$

$\mathrm{x}$

$\mathrm{x}$

$\mathrm{x}$

$x$

$\mathrm{X}$
Miss Basin

X

$\mathrm{X}$

X

X

X

X

X

$\mathrm{X}$

$\mathrm{X}$

X

$\mathrm{X}$

X

X

$\mathrm{X}$

$\mathrm{X}$

X

X

X

X

$\mathrm{x}$

$\mathrm{X} \quad \mathrm{X}$

$\mathrm{X} \mathbf{x}$

$\mathrm{X} \quad \mathrm{X}$

$\mathrm{X}$

$\mathrm{X}$ X

$\mathrm{X} X$

$\mathrm{x}$ X

$\mathrm{X}$

$\mathrm{X}$

$\mathbf{X}$

$\mathbf{X}$

$\mathbf{x}$ 
Table B6. Mussels collected from Fort Polk, Kisatchie National Forest, and the Calcasieu drainages just downstream from the sites selected for this study. Station numbers correspond to those in the original text (Vidrine, 1996c)

51. Louisiana. Vernon Parish. Calcasieu River at Rt. LA 8. 21 June 1975. M. F. Vidrine.

Hosts examined

Uniomerus tetralasmus

Glebula rotundata

Lampsilis hydiana
Number of hosts examined 12 3 3
Parasites

Najadicola ingens

none

Unionicola hoesei

Unionicola abnormipes
Number of hosts infested

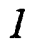

3

3

52. Louisiana. Vernon Parish. Calcasieu River at Rt. LA 489. 21 June 1975. M.F. Vidrine.

Hosts examined

Quadrula p. mortoni

Lampsilis hydiana

Fusconaia askewi

Villosa lienosa

Campeloma decisum

Number of hosts
examined
1
4

2

8

5
Parasites

Unionicola vikitra

Unionicola hoesei

Unionicola abnormipes

Unionicola parkeri

Unionicola serrata

Unionicola gailae

none
Number of hosts infested

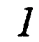

4

4

1

1

6

53. Louisiana. Rapides Parish. Calcasieu River at junction of Rts. LA 112 and 121, near Hineston. 20 July 1974. M.S. DeRouen, Blake and M.F. Vidrine.

Hosts examined

Fusconaia askewi

Quadrula p. mortoni

Tritogonia verrucosa

Lampsilis hydiana

Villosa lienosa

Toxolasma parvus

Obovaria jacksoniana

Strophitus subvexus

Campeloma decisum
Number of hosts
examined

54

13

5

5

4

2

7

2

15
Parasites

Unionicola parkeri

Unionicola serrata

Unionicola vikitra

Unionicola serrata

Unionicola vamana

Unionicola hoesei

Unionicola gailae

Unionicola kavanaghi

none

Unionicola dimocki

none
Number of hosts

infested

18

5

7

3

5

5

4

1

2 
Table B6. Mussels collected from Fort Polk, Kisatchie National Forest, and the Calcasieu drainages just downstream from the sites selected for this study. Station numbers correspond to those in the original text (Vidrine, 1996c)--Continued

54. Louisiana. Rapides Parish. Calcasieu River at junction of Rts. LA 112 and 121, Hineston. 4 October 1986. Macky and M.F. Vidrine.

Hosts examined

Strophitus subvexus

Fusconaia askewi

Tritogonia verrucosa

Lampsilis hydiana

Villosa lienosa

Toxolasma parvus

Obovaria jacksoniana

Pleurobema riddelli

Lampsilis teres

Quadrula p. mortoni

Uniomerus declivus

Campeloma decisum

$$
\text { Number of hosts }
$$$$
\text { examined }
$$

$$
9
$$

98

6

25

40

11

26

6

3

9

4

50
Parasites

Unionicola dimocki

Unionicola serrata

Unionicola parkeri

Najadicola ingens

Unionicola vamana

Unionicola serrata

Unionicola hoesei

Unionicola abnormipes

Unionicola gailae

Unionicola serrata

Unionicola kavanaghi

Unionicola serrata

Najadicola ingens

Unionicola gailae

Unionicola abnormipes

Unionicola gowani

Najadicola ingens

Unionicola hoesei

Unionicola vikitra

Unionicola serrata

Najadicola ingens

Unionicola campelomaicola
Number of hosts infested

8

28

12

1

6

2

25

6

36

20

7

2

2

1

1

1

1

3

9

3

3

2 
Table B6. Mussels collected from Fort Polk, Kisatchie National Forest, and the Calcasieu drainages just downstream from the sites selected for this study. Station numbers correspond to those in the original text (Vidrine, 1996c)--Continued

55. Louisiana. Rapides Parish. Calcasieu River at junction of Rts. LA 112 and 121, Hineston. 21 September 1991. Bruno Borsari and M.F. Vidrine.

Hosts examined

Strophitus subvexus

Fusconaia askewi

Tritogonia verrucosa

Lampsilis hydiana

Villosa lienosa

Pleurobema riddelli

Lampsilis teres

Quadrula p. mortoni

Uniomerus declivus
Number of hosts examined 7 79
Parasites

Unionicola dimocki

Unionicola serrata

Unionicola parkeri

Najadicola ingens

Unionicola vamana

Najadicola ingens

Unionicola hoesei

Unionicola abnormipes

Unionicola gailae

Unionicola serrata

Unionicola gowani

Najadicola ingens

Unionicola hoesei

Unionicola vikitra

Unionicola serrata

Najadicola ingens

Unionicola stricta
Number of hosts infested 7 11 1

3

3

1

37

7

27

10

1

1

1

6

1

3

2 
Table B6. Mussels collected from Fort Polk, Kisatchie National Forest, and the Calcasieu drainages just downstream from the sites selected for this study. Station numbers correspond to those in the original text (Vidrine, 1996c)--Continued

56. Louisiana. Rapides Parish. Calcasieu River at junction of Rts. LA 112 and 121, Hineston. 25 August 1978. D.J. Bereza, S.S. Roback, and M.F. Vidrine.

\begin{tabular}{|c|c|c|c|}
\hline Hosts examined & $\begin{array}{c}\text { Number of hosts } \\
\text { examined }\end{array}$ & Parasites & $\begin{array}{c}\text { Number of hosts } \\
\text { infested }\end{array}$ \\
\hline \multirow{2}{*}{ Lampsilis satur } & 1 & Unionicola hoesei & 1 \\
\hline & & Unionicola serrata & 1 \\
\hline \multirow[t]{2}{*}{ Strophitus subvexus } & 16 & Unionicola dimocki & 16 \\
\hline & & Unionicola abnormipes & 1 \\
\hline \multirow[t]{3}{*}{ Villosa lienosa } & 18 & Unionicola serrata & 18 \\
\hline & & Unionicola gailae & 18 \\
\hline & & Unionicola abnormipes & 1 \\
\hline \multirow[t]{2}{*}{ Toxolasma parvus } & 5 & Unionicola kavanaghi & 4 \\
\hline & & Najadicola ingens & 2 \\
\hline \multirow[t]{2}{*}{ Lampsilis teres } & 6 & Unionicola hoesei & 6 \\
\hline & & Unionicola abnormipes & 6 \\
\hline \multirow[t]{2}{*}{ Lampsilis hydiana } & 29 & Unionicola hoesei & 29 \\
\hline & & Unionicola abnormipes & 29 \\
\hline \multirow[t]{2}{*}{ Fusconaia askewi } & 60 & Unionicola parkeri & 30 \\
\hline & & Unionicola serrata & 30 \\
\hline \multirow[t]{2}{*}{ Tritogonia verrucosa } & 10 & Unionicola vamana & 10 \\
\hline & & Najadicola ingens & 1 \\
\hline Pleurobema riddelli & 9 & Unionicola gowani & 9 \\
\hline Uniomerus declivus & 1 & none & \\
\hline Quadrula p. mortoni & 8 & Unionicola vikitra & 8 \\
\hline Leptodea fragilis & 1 & Unionicola serrata & 1 \\
\hline Obovaria jacksoniana & 3 & none & \\
\hline
\end{tabular}


Table B6. Mussels collected from Fort Polk, Kisatchie National Forest, and the Calcasieu drainages just downstream from the sites selected for this study. Station numbers correspond to those in the original text (Vidrine, 1996c)--Continued

57. Louisiana. Rapides Parish. Calcasieu River ca. 5-7 miles north of junction of Rt. LA 112 and 113, northwest of Glenmora, at small bridge just east on secondary highway off Rt. LA 112. 3 August 1991. Daniel and M.F. Vidrine.

Hosts examined

Lampsilis teres

Tritogonia verrucosa

Obovaria jacksoniana

Toxolasma parvus

Fusconaia askewi

Pleurobema riddelli

Villosa lienosa

Quadrula p. mortoni

Lampsilis hydiana

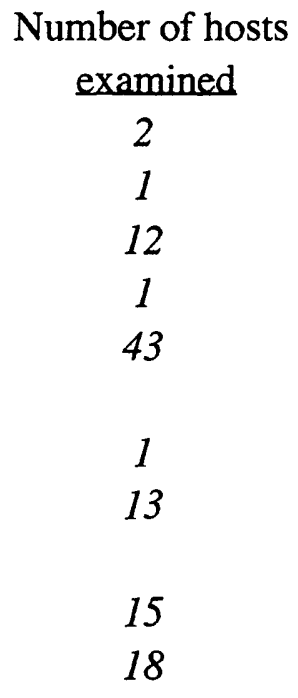

Parasites

Unionicola hoesei

none

none

none

Unionicola parkeri

Unionicola serrata

Unionicola gowani

Unionicola gailae

Unionicola serrata

Unionicola vikitra

Unionicola hoesei

Unionicola abnormipes
Number of hosts infested

2

17

16

1

8

6

14

17

3 
Table B6. Mussels collected from Fort Polk, Kisatchie National Forest, and the Calcasieu drainages just downstream from the sites selected for this study. Station numbers correspond to those in the original text (Vidrine, 1996c)--Continued

58. Louisiana. Rapides Parish. Calcasieu River at Rt. LA 113, west of Glenmora. 5 October 1974. Blaine and M.F. Vidrine.

Hosts examined

Strophitus subvexus

Fusconaia askewi

Toxolasma parvus

Quadrula p. mortoni

Obovaria jacksoniana

Tritogonia verrucosa

Villosa lienosa

Lampsilis hydiana

Uniomerus declivus

Amblema plicata

Lampsilis teres

Campeloma decisum
Number of hosts examined

1

1

1

6
Parasites

Unionicola dimocki

Unionicola parkeri

Unionicola kavanaghi

Najadicola ingens

Unionicola vikitra

Unionicola serrata

Unionicola abnormipes

none

Unionicola vamana

Unionicola gailae

Unionicola serrata

Unionicola hoesei

Unionicola abnormipes

Unionicola serrata

Najadicola ingens

Unionicola stricta

Unionicola amandita

Najadicola ingens

Unionicola hoesei

Unionicola abnormipes

none
Number of hosts

infested

1

9

10

2

4

1

1

2

17

2

55

14

3

1

1

1

1

1

1 
Table B6. Mussels collected from Fort Polk, Kisatchie National Forest, and the Calcasieu drainages just downstream from the sites selected for this study. Station numbers correspond to those in the original text (Vidrine, 1996c)--Continued

59. Louisiana. Rapides Parish. Calcasieu River at Rt. LA 113, ca. 4-5 miles west of Glenmora. 11 October 1986. M.F. Vidrine.

\begin{tabular}{|c|c|c|c|}
\hline Hosts examined & $\begin{array}{l}\text { Number of hosts } \\
\text { examined }\end{array}$ & Parasites & $\begin{array}{l}\text { umber of hosts } \\
\text { infested }\end{array}$ \\
\hline Strophitus subvexus & 1 & Unionicola dimocki & 1 \\
\hline \multirow[t]{3}{*}{ Fusconaia askewi } & 83 & Unionicola parkeri & 37 \\
\hline & & Unionicola serrata & 20 \\
\hline & & Najadicola ingens & 5 \\
\hline \multirow[t]{2}{*}{ Pleurobema riddelli } & 6 & Unionicola gowani & 1 \\
\hline & & Najadicola ingens & 1 \\
\hline \multirow[t]{2}{*}{ Lampsilis teres } & 5 & Unionicola hoesei & 5 \\
\hline & & Unionicola abnormipes & 4 \\
\hline \multirow[t]{2}{*}{ Tritogonia verrucosa } & 3 & Unionicola vamana & 3 \\
\hline & & Najadicola ingens & 1 \\
\hline Quadrula p. mortoni & 8 & Unionicola vikitra & 7 \\
\hline \multirow[t]{2}{*}{ Uniomerus declivus } & 10 & Najadicolaingens & 1 \\
\hline & & Unionicola stricta & 2 \\
\hline \multirow[t]{3}{*}{ Villosa lienosa } & 33 & Unionicola gailae & 29 \\
\hline & & Unionicola serrata & 29 \\
\hline & & Unionicola laurentiana & 33 \\
\hline \multirow[t]{2}{*}{ Lampsilis hydiana } & 35 & Unionicola hoesei & 34 \\
\hline & & Unionicola abnormipes & 16 \\
\hline Obovaria jacksoniana & 20 & none & \\
\hline \multirow[t]{3}{*}{ Toxolasma parvus } & 35 & Unionicola kavanaghi & 21 \\
\hline & & Unionicola laurentiana & 1 \\
\hline & & Najadicola ingens & 3 \\
\hline Pyganodon grandis & 3 & none & \\
\hline \multirow[t]{2}{*}{ Amblema plicata } & 4 & Unionicola amandita & 4 \\
\hline & & Najadicola ingens & 2 \\
\hline Ligumia subrostrata & 2 & Unionicola serrata & 1 \\
\hline Corbicula fluminea & 11 & none & \\
\hline Campeloma decisum & 100 & Unionicola campelomaicola & 12 \\
\hline
\end{tabular}


Table B6. Mussels collected from Fort Polk, Kisatchie National Forest, and the Calcasieu drainages just downstream from the sites selected for this study. Station numbers correspond to those in the original text (Vidrine, 1996c)--Continued

60. Louisiana. Allen Parish. Calcasieu River at Rt. LA 10, above impoundment, Oakdale.

27 November 1976. Blake and M.F. Vidrine.

$\begin{array}{lclc}\text { Hosts examined } & \begin{array}{c}\text { Number of hosts } \\ \text { examined }\end{array} & \text { Parasites } & \begin{array}{c}\text { Number of hosts } \\ \text { infested }\end{array} \\ \text { Villosa lienosa } & 5 & \begin{array}{l}\text { Unionicola gailae } \\ \text { Unionicola serrata }\end{array} & 5 \\ \text { Lampsilis hydiana } & 10 & \begin{array}{l}\text { Unionicola hoesei } \\ \text { Unionicola abnormipes }\end{array} & 10 \\ \text { Lampsilis teres } & 1 & \text { Unionicola hoesei } & 10 \\ \text { Obovaria jacksoniana } & 2 & \text { none } & 1 \\ \text { Quadrula p. mortoni } & 1 & \text { Unionicola vikitrella } & 1 \\ \text { Amblema plicata } & 3 & \text { Unionicola amandita } & 2 \\ \text { Toxolasma parvus } & 3 & \text { none } & \\ \text { Fusconaia askewi } & 7 & \text { Unionicola serrata } & 1\end{array}$

61. Louisiana. Allen Parish. Calcasieu River ca. 5 miles south of Oakdale. 4 June 1973. M. Topping, Blake and M.F. Vidrine.

$\begin{array}{lclc}\text { Hosts examined } & \begin{array}{c}\text { Number of hosts } \\ \text { examined }\end{array} & \text { Parasites } & \begin{array}{c}\text { Number of hosts } \\ \text { infested }\end{array} \\ \text { Obliquaria reflexa } & 1 & \text { none } & \\ \text { Obovaria jacksoniana } & 20 & \text { none } & \\ \text { Toxolasma parvus } & 1 & \text { none } & \\ \text { Fusconaia askewi } & 4 & \text { Unionicola parkeri } & 2 \\ \text { Quadrula p. mortoni } & 19 & \begin{array}{l}\text { Unionicola vikitra } \\ \text { Unionicola hoesei }\end{array} & 10 \\ \text { Lampsilis hydiana } & 4 & \text { Unionicola abnormipes } & 2 \\ & & \text { none } & 3 \\ \text { Leptodea fragilis } & 1 & \text { Unionicola hoesei } & 3 \\ \text { Lampsilis teres } & 9 & \begin{array}{l}\text { Unionicola abnormipes } \\ \text { none }\end{array} & 3 \\ \text { Amblema plicata } & 3 & \text { Unionicola hoesei } & \text { Unionicola abnormipes } \\ \text { Lampsilis satur } & 8 & \text { Unionicola serrata } & 3 \\ & & & 3\end{array}$


Table B6. Mussels collected from Fort Polk, Kisatchie National Forest, and the Calcasieu drainages just downstream from the sites selected for this study. Station numbers correspond to those in the original text (Vidrine, 1996c)--Continued

62. Louisiana. Allen Parish. Calcasieu River at Rt. U.S. 190, west of Kinder. 6 June 1977. M.G. Curry, B. Everitt, W. Bell, D.R. Clark, Macky and M.F. Vidrine.

$\begin{array}{lclc}\begin{array}{l}\text { Hosts examined } \\ \text { Pyganodon grandis }\end{array} & \begin{array}{c}\text { Number of hosts } \\ \text { examined }\end{array} & \begin{array}{l}\text { Parasites } \\ \text { none }\end{array} & \begin{array}{c}\text { Number of hosts } \\ \text { infested }\end{array} \\ \text { Toxolasma parvus } & 1 & \begin{array}{l}\text { Unionicola vamana } \\ \text { none }\end{array} & 1 \\ \text { Uniomerus tetralasmus } & 1 & \begin{array}{l}\text { Najadicola ingens } \\ \text { Unionicola stricta }\end{array} & 2 \\ \text { Villosa lienosa } & 2 & \text { Unionicola gailae } & 1 \\ \text { Plectomerus dombeyanus } & 4 & \text { Unionicola tupara } & 3 \\ & & \text { Unionicola aculeata } & 2 \\ \text { Potamilus purpuratus } & 2 & \text { Unionicola hoesei } & 2 \\ & & \text { Unionicola australindistincta } & 1 \\ & & \text { Unionicola fulleri } & 1 \\ \text { Amblema plicata } & 6 & \text { Unionicola tupara } & 3 \\ \text { Fusconaia askewi } & 3 & \text { Unionicola aculeata } & 1 \\ \text { Quadrula p. mortoni } & 8 & \text { Unionicola vikitra } & 7 \\ \text { Obovaria jacksoniana } & 10 & \text { none } & \\ \text { Lampsilis satur } & 6 & \text { Unionicola hoesei } & 4 \\ & & \text { Unionicola abnormipes } & 2 \\ & & \text { Unionicola serrata } & 5 \\ \text { Lampsilis teres } & 2 & \text { Unionicola hoesei } & 2 \\ \text { Lampsilis hydiana } & 6 & \text { Unionicola hoesei } & 6 \\ \text { Unionicola abnormipes } & 2 & & \end{array}$


Table B6. Mussels collected from Fort Polk, Kisatchie National Forest, and the Calcasieu drainages just downstream from the sites selected for this study. Station numbers correspond to those in the original text (Vidrine, 1996c)--Continued

63. Louisiana. Allen Parish. Calcasieu River at Rt. U.S. 190, west of Kinder. 3 July 1976. Blake and M.F. Vidrine.

\begin{tabular}{|c|c|c|c|}
\hline Hosts examine & $\begin{array}{l}\text { Number of hosts } \\
\text { examined }\end{array}$ & Parasites & $\begin{array}{l}\text { aber of hosts } \\
\text { infested }\end{array}$ \\
\hline \multirow[t]{3}{*}{ Lampsilis satur } & 9 & Unionicola hoesei & 9 \\
\hline & & Unionicola serrata & 7 \\
\hline & & Unionicola abnormipes & 7 \\
\hline \multirow[t]{3}{*}{ Potamilus purpuratus } & 2 & Unionicola hoesei & 2 \\
\hline & & Unionicola fulleri & 1 \\
\hline & & Unionicola australindistincta & 1 \\
\hline \multirow{3}{*}{ Lampsilis teres } & 4 & Unionicola hoesei & 4 \\
\hline & & Unionicola aculeata & 1 \\
\hline & & Unionicola abnormipes & 2 \\
\hline \multirow[t]{3}{*}{ Lampsilis hydiana } & 6 & Unionicola hoesei & 5 \\
\hline & & Unionicola aculeata & 1 \\
\hline & & Unionicola abnormipes & 4 \\
\hline \multirow{2}{*}{ Quadrula p. mortoni } & 12 & Unionicola vikitra & 10 \\
\hline & & Unionicola vikitrella & 10 \\
\hline Uniomerus tetralasmus & 1 & none & \\
\hline \multirow[t]{2}{*}{ Tritogonia verrucosa } & 7 & Unionicola vamana & 6 \\
\hline & & Unionicola abnormipes & 1 \\
\hline \multirow[t]{2}{*}{ Fusconaia askewi } & 13 & Unionicola parkeri & 1 \\
\hline & & Unionicola aculeata & 5 \\
\hline \multirow[t]{2}{*}{ Plectomerus dombeyanus } & 11 & Unionicola tupara & 3 \\
\hline & & Unionicola megachela & 3 \\
\hline Amblema plicata & 17 & Unionicola amandita & 14 \\
\hline Corbicula fluminea & 1 & none & \\
\hline Campeloma decisum & 10 & none & \\
\hline
\end{tabular}


Table B6. Mussels collected from Fort Polk, Kisatchie National Forest, and the Calcasieu drainages just downstream from the sites selected for this study. Station numbers correspond to those in the original text (Vidrine, 1996c)--Continued

64. Louisiana. Allen Parish. Calcasieu River at Rt. U.S. 190, west of Kinder. 25 August 1978. D.J. Bereza, S.S. Roback, and M.F. Vidrine.

$\begin{array}{lclc}\text { Hosts examined } & \begin{array}{c}\text { Number of hosts } \\ \text { examined }\end{array} & \begin{array}{l}\text { Parasites } \\ \text { Unionicola hoesei }\end{array} & \begin{array}{c}\text { Number of hosts } \\ \text { infested }\end{array} \\ \text { Lampsilis satur } & 24 & \begin{array}{l}\text { Unionicola serrata } \\ \text { Unionicola abnormipes }\end{array} & 24 \\ & & \begin{array}{l}\text { Unionicola hoesei } \\ \text { Unionicola fulleri }\end{array} & 24 \\ \text { Potamilus purpuratus } & 4 & \begin{array}{l}\text { Unionicola australindistincta } \\ \text { Unionicola megachela }\end{array} & 4 \\ & & \text { Unionicola hoesei } & 4 \\ & & \text { Unionicola abnormipes } & 9 \\ \text { Lampsilis teres } & 9 & \text { Unionicola hoesei } & 9 \\ & & \text { Unionicola abnormipes } & 3 \\ \text { Lampsilis hydiana } & 3 & \text { Unionicola gailae } & 1 \\ & & \text { Unionicola vikitra } & 1 \\ \text { Villosa lienosa } & 1 & \text { none } & \\ \text { Obliquariare flexa } & 1 & \text { Unionicola vamana } & 3 \\ \text { Plectomerus dombeyanus } & 1 & \text { Unionicola amandita } & 1 \\ \text { Tritogonia verrucosa } & 3 & & \end{array}$


Table B6. Mussels collected from Fort Polk, Kisatchie National Forest, and the Calcasieu drainages just downstream from the sites selected for this study. Station numbers correspond to those in the original text (Vidrine, 1996c)--Continued

65. Louisiana. Allen Parish. Calcasieu River at boat ramp at Indian Village, ca. 1.5 miles north of Jefferson Davis Parish line. 3 September 1983. Gail Quillman, Macky and M.F. Vidrine.

Hosts examined

Obliquaria reflexa

Quadrula p. mortoni

Pyganodon grandis

Utterbackia imbecillis

Potamilus purpuratus

Pleurobema riddelli

Ligumia subrostrata

Villosa lienosa

Obovaria jacksoniana

Tritogonia verrucosa

Toxolasma parvus

Glebula rotundata

Amblema plicata

Plectomerus dombeyanus

Lampsilis teres

Lampsilis hydiana

Corbicula fluminea

Campeloma decisum
Number of hosts

$$
\text { examined }
$$

1

1

1

1

1

3

3

4

3

2

9

5

6

6

4

7

3

6
Parasites

Unionicola vikitra

Unionicola vikitra

Unionicola megachela

none

Unionicola hoesei

none

none

Unionicola gailae

none

Unionicola vamana

none

Unionicola hoesei

Unionicola tupara

Unionicola tupara

Unionicola hoesei

Unionicola abnormipes

Unionicola hoesei

Unionicola abnormipes

none

none
Number of hosts infested

1

1

1

1

4

2

5

6

2

4

4

7

7 
Table B6. Mussels collected from Fort Polk, Kisatchie National Forest, and the Calcasieu drainages just downstream from the sites selected for this study. Station numbers correspond to those in the original text (Vidrine, 1996c)--Continued

66. Louisiana. Allen Parish. Calcasieu River at boat ramp at Indian Village, ca. 1.5 miles north of Jefferson Davis Parish line. 20 October1991. M.F. Vidrine.

$\begin{array}{lclc}\text { Hosts examined } & \begin{array}{c}\text { Number of hosts } \\ \text { examined }\end{array} & \begin{array}{l}\text { Parasites } \\ \text { Unionicola amandita }\end{array} & \begin{array}{c}\text { Number of hosts } \\ \text { infested }\end{array} \\ \begin{array}{l}\text { Amblema plicata } \\ \text { Lampsilis teres }\end{array} & 33 & \begin{array}{l}\text { Unionicola hoesei } \\ \text { Unionicola abnormipes }\end{array} & 20 \\ \text { Lampsilis hydiana } & 20 & \begin{array}{l}\text { Unionicola hoesei } \\ \text { Unionicola abnormipes }\end{array} & 17 \\ \text { Plectomerus dombeyanus } & 29 & \text { Unionicola megachela } & 12 \\ & & \text { Unionicola tupara } & 12 \\ \text { Pyganodon grandis } & 7 & \text { Unionicola formosa } & 2 \\ & & \text { Unionicola mitchelli } & 3 \\ & & \text { Unionicola abnormipes } & 1 \\ \text { Utterbackia imbecillis } & 2 & \text { Unionicola foili } & 2 \\ \text { Villosa lienosa } & 3 & \text { Unionicola gailae } & 2 \\ \text { Toxolasma texasensis } & 6 & \text { Unionicola abnormipes } & 1 \\ \text { Ligumia subrostrata } & 2 & \text { none } & \\ \text { Glebula rotundata } & 4 & \text { Unionicola hoesei } & 3 \\ \text { Tritogonia verrucosa } & 5 & \text { Unionicola vamana } & 5 \\ & & \text { Unionicola abnormipes } & 1 \\ \text { Quadrula p. mortoni } & 24 & \text { Unionicola vikitral } & 2 \\ & & \text { Unionicola vikitrella } & 12 \\ \text { Obovaria jacksoniana } & 21 & \text { none } & \\ \text { Corbicula fluminea } & 1 & \text { none } & \\ \text { Campeloma decisum } & 7 & \text { none } & \end{array}$


Table B6. Mussels collected from Fort Polk, Kisatchie National Forest, and the Calcasieu drainages just downstream from the sites selected for this study. Station numbers correspond to those in the original text (Vidrine, 1996c)--Continued

67. Louisiana. Allen Parish. Bundick's Creek at Rt. LA 113. 30 August 1975. Blake and M.F. Vidrine.

$\begin{array}{lclc}\text { Hosts examined } & \begin{array}{c}\text { Number of hosts } \\ \text { examined }\end{array} & \text { Parasites } & \begin{array}{c}\text { Number of hosts } \\ \text { infested }\end{array} \\ \text { Lampsilis hydiana } & 8 & \text { Unionicola hoesei } & 5 \\ \text { Lampsilis satur } & 11 & \text { Unionicola hoesei } & 4 \\ \text { Obovaria jacksoniana } & 15 & \text { Unionicola campelomaicola } & 1 \\ \text { Lampsilis teres } & 9 & \text { Unionicola hoesei } & 9 \\ \text { Quadrula p. mortoni } & 11 & \text { Unionicola vikitra } & 9 \\ & & \text { Unionicola vikitrella } & 9 \\ \text { Strophitus subvexus } & 1 & \text { none } & \\ \text { Tritogonia verrucosa } & 1 & \text { Unionicola vamana } & 1 \\ \text { Campeloma decisum } & 20 & \text { Unionicola campelomaicola } & 1\end{array}$

68. Louisiana. Allen Parish. Bundick's Creek at Rt. LA 113. 17 March 1978. USL Aquatic insects class.

$\begin{array}{lclc}\text { Hosts examined } & \begin{array}{c}\text { Number of hosts } \\ \text { examined }\end{array} & \text { Parasites } & \begin{array}{c}\text { Number of hosts } \\ \text { infested }\end{array} \\ \text { Leptodea fragilis } & 1 & \text { Unionicola hoesei } & 1\end{array}$

69. Louisiana. Beauregard Parish. Bundick's Creek at Rt. LA 26, east of DeRidder. 30 August 1975. Blake and M.F. Vidrine.

Hosts examined

Tritogonia verrucosa

Lampsilis hydiana

Quadrula p . mortoni

Fusconaia askewi

Campeloma decisum

$\begin{gathered}\text { Number of hosts } \\ \text { examined }\end{gathered}$
1
11
1
8
5

Parasites

none

Unionicola hoesei

Unionicola abnormipes

Unionicola vikitra

Unionicola parkeri

none
Number of hosts

infested

11

2

1

3 
Table B6. Mussels collected from Fort Polk, Kisatchie National Forest, and the Calcasieu drainages just downstream from the sites selected for this study. Station numbers correspond to those in the original text (Vidrine, 1996c)--Continued

70. Louisiana. Allen Parish. Whiskey Chitto just north of Rt. U.S. 190, near LeBlanc at Methodist Day Camp. 23 May 1977. Darryl Felder.

Hosts examined

Amblema plicata

Lampsilis satur

Lampsilis teres

Obovaria jacksoniana
Number of hosts examined

1

3

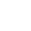

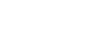

1

1
Parasites

Unionicola aculeata

Unionicola aculeata

Unionicola hoesei

Unionicola abnormipes

Unionicola serrata

Unionicola hoesei

Unionicola abnormipes

Unionicola serrata

Unionicola aculeata
Number of hosts infested

1
1
3
3
2
1
1
1
1

71. Louisiana. Allen Parish. Whiskey Chitto at Rt. LA 26. 27 November 1976. Blake and M.F. Vidrine.

\begin{tabular}{|c|c|c|c|}
\hline Hosts examined & $\begin{array}{l}\text { Number of hosts } \\
\text { examined }\end{array}$ & Parasites & $\begin{array}{c}\text { Number of hosts } \\
\text { infested }\end{array}$ \\
\hline Fusconaia askewi & 10 & Unionicola parkeri & 10 \\
\hline Obovaria jacksoniana & 4 & none & \\
\hline \multirow[t]{2}{*}{ Lampsilis hydiana } & 10 & Unionicola hoesei & 10 \\
\hline & & Unionicola abnormipes & 10 \\
\hline Quadrula p. mortoni & 1 & Unionicola vikitra & 1 \\
\hline Villosa lienosa & 1 & Unionicola gailae & 1 \\
\hline Corbicula fluminea & 4 & none & \\
\hline Campeloma decisum & 1 & none & \\
\hline
\end{tabular}


Table B6. Mussels collected from Fort Polk, Kisatchie National Forest, and the Calcasieu drainages just downstream from the sites selected for this study. Station numbers correspond to those in the original text (Vidrine, 1996c)--Continued

72. Louisiana. Beauregard Parish. Bundick's Creek at Rt. LA 113, ca. 1 mile north of Dry Creek. 19 July 1975. Blake and M.F. Vidrine.

$\begin{array}{lclc}\text { Hosts examined } & \begin{array}{c}\text { Number of hosts } \\ \text { examined }\end{array} & \text { Parasites } & \begin{array}{c}\text { Number of hosts } \\ \text { infested }\end{array} \\ \text { Lampsilis satur } & 7 & \text { Unionicola hoesei } & 5 \\ \text { Strophitus subvexus } & 1 & \text { none } & \\ \text { Villosa lienosa } & 1 & \text { none } & \\ \text { Lampsilis hydiana } & 1 & \text { Unionicola hoesei } & 1 \\ \text { Quadrula p. mortoni } & 9 & \text { Unionicola vikitra } & 6 \\ & & \text { Unionicola vikitrella } & 6 \\ \text { Lampsilis teres } & 4 & \text { Unionicola hoesei } & 4 \\ \text { Fusconaia askewi } & 2 & \text { none } & \\ \text { Truncilla donaciformis } & 1 & \text { none } & \\ \text { Obovaria jacksoniana } & 5 & \text { none } & \\ \text { Campeloma decisum } & 10 & \text { none }\end{array}$

73. Louisiana. Vernon Parish. Thompson Brook (Ten Mile Creek) at Rt. LA 113. 17 March 1978. USL Aquatic insects class.

Hosts examined

Lampsilis hydiana

Fusconaia askewi

Toxolasma parvus

Villosa lienosa

Campeloma decisum
Number of hosts examined

10

4

8

12

4
Parasites

Unionicola hoesei

Unionicola abnormipes

Unionicola parkeri

Unionicola serrata

Unionicola serrata

Unionicola kavanaghi

Najadicola ingens

Unionicola gailae

Unionicola serrata

none
Number of hosts infested

$$
10
$$

10

3

3

1

8

4

12

12 
Table B6. Mussels collected from Fort Polk, Kisatchie National Forest, and the Calcasieu drainages just downstream from the sites selected for this study. Station numbers correspond to those in the original text (Vidrine, 1996c)--Continued

74. Louisiana. Vernon Parish. Thompson Brook (Ten Mile Creek) at Rt. LA 113. 1 April 1994. M.F. Vidrine

Hosts examined

Strophitus subvexus
Number of hosts Parasites examined
Number of hosts infested

Unionicola dimocki
1

75. Louisiana. Beauregard Parish. Deer Creek at Rt. LA 26, ca. 3 miles east of Bundick's Creek. 30 August 1975. Blake and M.F. Vidrine.

Hosts examined

Lampsilis hydiana

Villosa lienosa

Campeloma decisum
Number of hosts examined 9 5 1
Parasites

Unionicola hoesei Unionicola abnormipes Unionicola gailae none
Number of hosts infested 7 2 4

76. Louisiana. Vernon Parish. Mims Creek at Rt. LA 465. 21 June 1975. M.F. Vidrine.

Hosts examined

Uniomerus tetralasmus
Number of hosts examined
9
Parasites
Unionicola stricta

Number of hosts infested 8

77. Louisiana. Vernon Parish. Drake's Creek at Lookout Road, Fort Polk. 19 August 1991. Charles Allen, Dawn Allen, and M.F. Vidrine.

$\begin{array}{lccc}\text { Hosts examined } & \begin{array}{c}\text { Number of hosts } \\ \text { examined }\end{array} & \text { Parasites } & \begin{array}{c}\text { Number of hosts } \\ \text { infested }\end{array} \\ \text { Utterbackia imbecillis } & 48 & \text { Unionicola foili } & 48\end{array}$
(=Utterbackia sp. nr. peggyae sensu Hoeh 1994, personal communication) 
Table B6. Mussels collected from Fort Polk, Kisatchie National Forest, and the Calcasieu drainages just downstream from the sites selected for this study. Station numbers correspond to those in the original text (Vidrine, 1996c)--Continued

78. Louisiana. Vernon Parish. Comrade Creek ca. 4 km downstream from Kurthwood Road, downstream from Peason Ridge (Ft.Polk). 1990. M.F. Vidrine.

\begin{tabular}{|c|c|c|c|}
\hline Hosts examined & $\begin{array}{c}\text { Number of hosts } \\
\text { examined }\end{array}$ & Parasites & $\begin{array}{l}\text { Number of hosts } \\
\quad \text { infested }\end{array}$ \\
\hline Uniomerus tetralasmus & 1 & none & \\
\hline Obovaria jacksoniana & 1 & none & \\
\hline \multirow[t]{2}{*}{ Villosa lienosa } & 5 & Unionicola gailae & 5 \\
\hline & & Unionicola serrata & 2 \\
\hline \multirow[t]{3}{*}{ Lampsilis hydiana } & 10 & Unioincola hoesei & 10 \\
\hline & & Unionicola abnormipes & 5 \\
\hline & & Unionicola serrata & 1 \\
\hline
\end{tabular}

79. Louisiana. Vernon Parish. Drake's Creek ca. $1 / 2$ mile downstream from Lookout Road, Kisatchie National Forest. 26 September 1993. James Cordes and M.F. Vidrine.

$\begin{array}{lclc}\text { Hosts examined } & \begin{array}{c}\text { Number of hosts } \\ \text { examined }\end{array} & \text { Parasites } & \begin{array}{c}\text { Number of hosts } \\ \text { infested }\end{array} \\ \text { Uniomerus tetralasmus } & 3 & \begin{array}{l}\text { Najadicola ingens } \\ \text { Unionicola serrata }\end{array} & 3 \\ \text { Lampsilis hydiana } & 3 & \begin{array}{l}\text { Najadicola ingens } \\ \text { Unionicola hoesei }\end{array} & 1 \\ & & \text { Unionicola abnormipes } & 1 \\ \text { Villosa lienosa } & & \text { Unionicola gailae } & 1 \\ \text { Utterbackia imbecillis } & 1 & \text { none }\end{array}$

80. Louisiana. Vernon Parish. Liberty Creek at northwest edge of Fort Polk Military Base. November 1988. M.F. Vidrine.

\begin{tabular}{|c|c|c|c|}
\hline Hosts examined & $\begin{array}{c}\text { Number of hosts } \\
\text { examined }\end{array}$ & Parasites & $\begin{array}{c}\text { Number of hosts } \\
\text { infested }\end{array}$ \\
\hline \multirow{3}{*}{ Villosa lienosa } & 2 & Unionicola gailae & 2 \\
\hline & & Unionicola serrata & 2 \\
\hline & & Unionicola abnormipes & 1 \\
\hline \multirow[t]{2}{*}{ Lampsilis hydiana } & 8 & Unionicola hoesei & 8 \\
\hline & & Unionicola abnormipes & 8 \\
\hline
\end{tabular}


Table B6. Mussels collected from Fort Polk, Kisatchie National Forest, and the Calcasieu drainages just downstream from the sites selected for this study. Station numbers correspond to those in the original text (Vidrine, 1996c)--Continued

81. Louisiana. Vernon Parish. Bundick's Creek at junction with Hogpen Branch, south of Fort Polk Military Base. November 1988. M.F. Vidrine.

$\begin{array}{lclc}\text { Hosts examined } & \begin{array}{c}\text { Number of hosts } \\ \text { examined }\end{array} & \text { Parasites } & \begin{array}{c}\text { Number of hosts } \\ \text { infested }\end{array} \\ \text { Villosa lienosa } & 1 & \begin{array}{l}\text { Unionicola gailae } \\ \text { Unionicola laurentiana } \\ \text { none }\end{array} & 1 \\ \text { Uniomerus tetralasmus } & 1 & 1\end{array}$

82. Louisiana. Vernon Parish. Drake's Creek at Lookout Road, Fort Polk Military Base. November 1988. M.F. Vidrine.

\begin{tabular}{|c|c|c|c|}
\hline Hosts examined & $\begin{array}{c}\text { Number of hosts } \\
\text { examined }\end{array}$ & Parasites & $\begin{array}{c}\text { Number of hosts } \\
\text { infested }\end{array}$ \\
\hline Toxolasma parvus & 5 & Unionicola kavanaghi & 5 \\
\hline Fusconaia askewi & 11 & none & \\
\hline \multirow[t]{2}{*}{ Villosa lienosa } & 17 & Unionicola gailae & 11 \\
\hline & & Unionicola serrata & 10 \\
\hline \multirow[t]{2}{*}{ Lampsilis hydiana } & 12 & Unioincola hoesei & 12 \\
\hline & & Unionicola abnormipes & 2 \\
\hline Campeloma decisum & 20 & none & \\
\hline
\end{tabular}

83. Louisiana. Vernon Parish. Whiskey Chitto Creek at Mill Creek Road (East Fork) ca. $50 \mathrm{~m}$ north of the road, Fort Polk Military Base. November 1988. M.F. Vidrine.

Hosts examined

Villosa lienosa

Uniomerus tetralasmus
Number of hosts $\quad$ Parasites examined

1

1 none

Unionicola stricta

Najadicola ingens
Number of hosts infested

$$
1
$$


Table B6. Mussels collected from Fort Polk, Kisatchie National Forest, and the Calcasieu drainages just downstream from the sites selected for this study. Station numbers correspond to those in the original text (Vidrine, 1996c)--Continued

84. Louisiana. Vernon Parish. Whiskey Chitto Creek at Mill Creek Road (East Fork) ca. $120 \mathrm{~m}$ north of road, Fort Polk Military Base. November 1988. M.F. Vidrine.

Hosts examined

Villosa lienosa

Uniomerus tetralasmus

Toxolasma parvus

Lampsilis hydiana

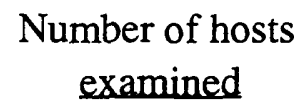

2

9

2

13
Parasites

Unionicola laurentiana

Unionicola stricta

Najadicola ingens

Unionicola laurentiana

none

Unionicola hoesei

Unionicola abnormipes

Unionicola laurentiana
Number of hosts infested

2

9

9

1

10

8

4

85. Louisiana. Vernon Parish. Whisky Chitto at Lookout Road, Fort Polk Military Base. November 1988. M.F. Vidrine.

$\begin{array}{lclc}\text { Hosts examined } & \begin{array}{c}\text { Number of hosts } \\ \text { examined }\end{array} & \text { Parasites } & \begin{array}{c}\text { Number of hosts } \\ \text { infested }\end{array} \\ \text { Villosa lienosa } & 14 & \begin{array}{l}\text { Unionicola gailae } \\ \text { Unionicola serrata }\end{array} & 14 \\ \text { Strophitus subvexus } & 1 & \begin{array}{l}\text { Unionicola dimocki } \\ \text { none }\end{array} & 14 \\ \text { Obovaria jacksoniana } & 21 & \text { Unionicola kavanaghi } & 27 \\ \text { Toxolasma parvus } & 27 & \text { Unionicola serrata } & 19 \\ & 16 & \text { Unionicola hoesei } & 16 \\ \text { Lampsilis hydiana } & 14 & \text { Unionicola serrata } & 10 \\ \text { Fusconaia askewi } & 3 & \text { none } & \\ \text { Campeloma decisum } & & & \end{array}$

86. Louisiana. Vernon Parish. Whisky Chitto at Lookout Road, Fort Polk Military Base. 11-12 August 1994. M.F. Vidrine, C.M. Allen, Andy Allen, and Harland Guillory.

Hosts examined

Strophitus subvexus

Fusconaia askewi
Number of hosts
examined

4

1
Parasites

Unionicola dimocki

Unionicola serrata
Number of hosts infested

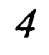

1 
Table B6. Mussels collected from Fort Polk, Kisatchie National Forest, and the Calcasieu drainages just downstream from the sites selected for this study. Station numbers correspond to those in the original text (Vidrine, 1996c)--Continued

87. Louisiana. Vernon Parish. Birds Creek at Lookout Road, Fort Polk Military Base. November 1988. M.F. Vidrine.

\begin{tabular}{|c|c|c|c|}
\hline Hosts examined & $\begin{array}{c}\text { Number of hosts } \\
\text { examined }\end{array}$ & Parasites & $\begin{array}{l}\text { Number of hosts } \\
\text { infested }\end{array}$ \\
\hline \multirow[t]{2}{*}{ Villosa lienosa } & 10 & Unionicola gailae & 10 \\
\hline & & Unionicola serrata & 8 \\
\hline Toxolasma parvus & 8 & none & \\
\hline \multirow[t]{2}{*}{ Lampsilis hydiana } & 25 & Unionicola hoesei & 25 \\
\hline & & Unionicola abnormipes & 23 \\
\hline Fusconaia askewi & 10 & Najadicola ingens & 1 \\
\hline
\end{tabular}

88. Louisiana. Vernon Parish. West Fork Six Mile Creek, Range 36, Fort Polk Military Base. November 1988. M.F. Vidrine.

$\begin{array}{lclc}\text { Hosts examined } & \begin{array}{c}\text { Number of hosts } \\ \text { examined }\end{array} & \text { Parasites } & \begin{array}{c}\text { Number of hosts } \\ \text { infested }\end{array} \\ \text { Villosa lienosa } & 2 & \text { Unionicola gailae } & 2 \\ \text { Lampsilis hydiana } & 1 & \text { Unionicola hoesei } & 1\end{array}$

89. Louisiana. Vernon Parish. West Fork Six Mile Creek at Lookout Road, Fort Polk Military Base. November 1988. M.F. Vidrine.

$\begin{array}{lccc}\text { Hosts examined } & \begin{array}{c}\text { Number of hosts } \\ \text { examined }\end{array} & \text { Parasites } & \begin{array}{c}\text { Number of hosts } \\ \text { infested }\end{array} \\ \text { Toxolasma parvus } & 2 & \text { Unionicola kavanaghi } & 2\end{array}$

90. Louisiana. Vernon Parish. East Fork Six Mile Creek at Lookout Road, Fort Polk Military Base. November 1988. M.F. Vidrine.

Hosts examined

Fusconaia askewi

Lampsilis hydiana
Number of hosts examined
Parasites

none

Unionicola hoesei
Number of hosts

infested 


\section{APPENDIX C: \\ BOTANICAL SUMMARY OF THE LIMITED USE AREA, VERNON RANGER DISTRICT, KISATCHIE NATIONAL FOREST, LOUISIANA}

\section{CONTENTS}

Introduction

Present status of Botanical Knowledge.

Plant Species

Vegetation

Rare and Endangered Species

Scenic Stream Vegetation

Selected References

Table C1: Plant species, with common name and Family, from the Limited Use Area, Vernon Ranger District, Kisatchie National Forest, Louisiana

Table C2: Plant Species and vegetational type(s) where found in the Limited Use Area, Vernon Ranger District, Kisatchie National Forest, Louisiana..

Table C3: Rare and endangered species, with state and global ranking, from Limited Use Area, Vernon Ranger District, Kisatchie National Forest, LA (K), or Fort Polk (F), or Vernon Parish (V)

Table C4: Plant Species reported only from riparian vegetation in the Limited Use Area, Vernon Ranger District, Kisatchie National Forest, Louisina, including Scenic Streams (Whiskey Chitto and Sixmile Creeks) 


\section{INTRODUCTION}

This report is based on field trips to the Kisatchie National Forest Limited Use Area in the Fall of 1996. Additional information comes from field trips and guided tours in the Limited Use Area since 1983. Some pertinent information also comes from fieldwork conducted on adjacent Fort Polk lands since 1983. The biota of Fort Polk has been the subject of a number of contracted studies and surveys and Fort Polk has one of the most (if not the most) complete inventories of plants and animals in the state of Louisiana. Supplementary data come from some of those reports. If one analyzes the Fort Polk biota inventory, it becomes apparent that management of Fort Polk has resulted in the creation of a habitat island in west central Louisiana.

\section{PRESENT STATUS OF BOTANICAL KNOWLEDGE}

\section{Plant Species}

The Limited Use Area has a diverse assemblage of vascular plants of 1297 species plus an additional 72 species that are reported from nearby Fort Polk and/or Vernon Parish. A listing of the plant species known to occur in the Limited Use Area is in Table C1. All species are listed with a common name and its family. The largest family is the Grass Family (Poaceae) with 190 species followed by the Sunflower Family (Asteraceae) with 180 species, the Sedge Family (Cyperaeae) with 119 species and the Legume Family (Fabaceae) with 97 species.

In Table $\mathrm{C} 2$, each species is listed and the vegetation type(s) that it is usually associated with is indicated by "+". Some species are restricted to one vegetation type, especially those of disturbed areas, but most species are known from two or more vegetation types. Mixed PineHardwood forest has the most species (561) and the open water areas has the least (52). In the Savannah areas, 500 species are known, in the disturbed areas 494, longleaf pine 457, sandy woodlands 425 , riparian 401 , baygalls 328 , bogs 277 , and swamps 260 . A total of 38 species (those marked with "*") are reported from Vernon Parish and could be found in the Limited Use Area and 34 species (marked with ${ }^{* *}$ ) are reported from Fort Polk and could be found in Limited Use Area. Almost all of these 34 species are from the Calcareous Prairie Ecosystem on the northwestern part of Fort Polk.

\section{Vegetation}

The kind of vegetation in an area is mainly controlled by the soil. Also, vegetation type is influenced by topography, water conditions, past human management techniques, and disturbances. The natural vegetation in the Kisatchie National Forest Limited Use Area can be divided into nine major types: sandy woodland, longleaf pine, mixed pine-hardwood, savannah, baygall, bog, riparian, swamp, and open water. The vegetation developed in disturbed areas constitutes the tenth vegetational type in the Limited Use Area. Four additional vegetational types are found on Fort Polk and could possibly exist in scattered and very limited areas across the Limited Use Area. These are calcareous prairie, Fleming calcareous forest, shortleaf-hickory, and sandstone glade. 
The higher and dryer sites in the area are occupied by the sandy woodland vegetation type. This vegetation type is primarily located in the northern part of the area. In its natural condition, the overstory in sandy woodlands is primarily a mixture of oaks (sandjack, blackjack, and runner) and pines (loblolly, shortleaf, and longleaf). The subcanopy and shrub layer are sparse with a few clumps of the genus Vaccinium (deerberry, Elliott's blueberry, or tree huckleberry). The floor is mostly bare with occasional clumps of goat's rue, puccoon, bull nettle, and other herbaceous species. In areas, clumps of poison oak form dense clumps along the floor. Lichen patches, mostly of the genus Cladonia, are also often scattered across the floor. A typical example of this vegetation type can be seen near the intersections of Forest Service Roads 400 and 471, just south of Little Cypress Recreation Area in the southeast corner of Section 11 T1S R8W. On Fort Polk, this vegetation type is developed mostly on Betis Loamy Fine Sand.

Downslope from the sandy woodlands and on the tops of less dry hills, the vegetation that develops is the longleaf pine forest. Longleaf pine forest is characterized by scattered large individual longleaf pine trees or small clumps of younger smaller trees creating a fairly open vegetation type. The dominant overstory species is longleaf pine with patches of loblolly pine scattered in many stands. A number of hardwoods can be in the overstory but hardwoods usually form a subcanopy or midstory layer. Many of the hardwoods are oaks such as southern red, post, blackjack, sandjack, runner, water, or Darlington's. Other hardwoods in the top layers include sweet gum, black gum, flowering dogwood, red maple, mockernut hickory, or black hickory. Shrubs usually occur in patches with some of the common species including yaupon, deerberry, Elliott's blueberry, tree huckleberry, waxmyrtle, and winged sumac. There are many herbaceous species but the most common two are bracken fern and little bluestem. A good example of this vegetation type can be found in the Longleaf Scenic Area southwest of the intersection of Forest Service Roads 421 and 444 in Sections 1 \& 12 T1S R8W and Sections 6 \& 7 T1S R7W.

In the more mesic, less dry hillside sites and also in cutover longleaf areas, the mixed pine-hardwood forest develops. This vegetation type is highly variable ranging from almost $100 \%$ pine to about half pine and half hardwoods. The stands with more pine usually are younger and are characterized by a very dense canopy. As the stands mature, the numbers of pines decrease and the canopy becomes more open. The most common pine is loblolly but most stands contain a few longleaf and other can contain shortleaf and in a few areas, slash pines are found. In older stands and in openings in the pines in younger stands, hardwoods can become a part of the canopy. Hardwood species are similar to those of the longleaf pine forest but sandjack, blackjack, and runner oaks are not commonly observed. Yaupon, Elliott's blueberry, tree huckleberry, french mulberry, and winged sumac are common shrubs. Saplings of flowering dogwood, sassafras, and persimmon are often found in the shrub layer. A good example of this can be found along the east side of the gravel road that runs north off of Forest Service Road 443 in Section 14 T1S R7W.

Savannah vegetation can be found in small patches or strips throughout the northern part of the area in flat and wet areas along streams. A large area of savannah vegetation occurs in the flat southwestern part of the area. This vegetation is characterized by a very open canopy of scattered pine trees. In the northern area, most of the trees are longleaf but many slash pines have been planted in the southern region. In very wet areas, clumps of hardwood trees often 
produce a subcanopy or midstory clump layer. Common species of these clumps include swamp blackgum, white bay, and red maple. The shrub layer is also open with scattered clumps of shrubs or saplings. Some of the shrub species usually found are red bay, white bay, large gallberry, chokecherry, and alder. Lowland bamboo vine is often twining on top of the shrubs. A dense layer of grasses-sedges and other herbaceous plants layer does fill in the space between the clumps of shrubs. Common grasses are toothache, switch, and several species of three-awns. Sedges include many species of nutsedge and especially beaksedge. Other herbaceous plants are often pitcher plants, sundews, and other plants usually found in bogs. A good example of the savannah vegetation in strips can be found downslope from the longleaf pine forest in the southern part of Section 4 T1S R8W off south of Forest Service Road 421. A good example of the large savannah vegetation type can be observed north of Forest Service Road 450 in Section 36 T1S R8W.

Bog vegetation is also called pitcher plant bog and develops in open areas in savannahs and baygalls. The area occupied by each bog is small but here are many scattered across the Limited Use Area. Bog plants are almost all herbaceous but clumps of woody plants are scattered in most bogs. These woody species could include any of those found in the savannah or baygall. Bogs are wet and almost all have a layer of peat moss (Sphagnum) right at the soil level. The soils are typically quite sandy and very acid ( $\mathrm{pH} 4.5-5.0)$. They are underlain by an impervious sandstone or clay layer, that where conditions are right, causes ground water to constantly seep to the soil surface. Many of the obvious plants throughout the year in the bog are carnivorous including pitcher plants, sundews, butterworts, and bladderworts. Seasonally, other plants become obvious and some of these include orchids, especially members of the genus Platanthera and members of the lily, carrot, and aster families. Less obvious but perhaps more dominant are grasses and sedges, especially beaksedges. A good example of a bog can be found south of Forest Service Road 400 in Section 13 T1S R8W.

Baygall vegetation is a forested type that develops along the edges of the smaller streams. Larger baygalls change into savannahs upslope or bogs in open areas. Very narrow baygalls may grade upslope to a longleaf pine forest or even a sandy woodland. In larger streams, baygall vegetation changes into riparian vegetation downstream. Baygall vegetation is mostly a short tree or tall shrub type but in some baygalls, a taller canopy is found. Most of the trees or shrubs are evergreen and include red bay, white bay, gall berry, alder, and swamp black gum. Lowland bamboo vine is found in almost all baygalls. The most common herbaceous plants are ferns including royal, cinnamon, southern lady, sensitive, netted chain, and Virginia Chain. Peat moss (Sphagnum) is found in scattered patches on the floor of most baygalls. A good example of a baygall can be found along the small stream that drains into Drake's Creek on the east bank just south of Forest Service Road 421 Section 1 T1S R8W.

Riparian vegetation is a large tree vegetation type that develops in the well drained areas along the sides of the larger streams such as Bird's, Whiskey Chitto, Drakes, Bundick's, or Six Mile Creeks. This vegetation type has a distinct canopy of hardwood trees plus a subcanopy or midstory layer. The shrub and herb layers are often poorly developed. Common canopy species include American beech, white oak, sweet gum, winged elm, and southern magnolia. Species usually found in the subcanopy layer are blue beech, hop hornbeam, and flowering dogwood. Common shrubs include arrowwood, silver bell, big snowbell, horsesugar, azalea, and Virginia 
willow. Herbaceous plants are usually scattered and some common species include inland seaoats, Christmas fern, partridge berry, elephant's foot, and many species of Carex. Two locations for typical riparian vegetation are just downstream from Lookout Road along the banks of the Whiskey Chitto Creek (Section 3 T1S R7W) and Bird's Creek (Section 35 T1N R7W).

Swamp vegetation develops in slow or nonmoving back water areas along the streams. It is a forest vegetation type that always has swamp black gum and usually also contains bald cypress and one or more oaks; cow, water, willow, overcup, or laurel. The crowns of these trees are usually very long vertically so the canopy is very distinct. Very few shrubs are found but the most common species is Virginia willow. In the less wet portions of the swamp, a distinct layer of herbaceous plants often develops. Common species include aster, broadleaf uniola, narrowleaf wood oats, and many species of the genus Carex. There are no large areas of swamp vegetation in the Limited Use Area but small patches can be found along the larger streams. One small area can be observed along Bundick's Creek off Forest Service Road 403 Section 16 T1S R8W.

There are a few open water areas in the Limited Use Area including the larger streams, larger back stream areas, beaver ponds, and some manmade ponds. Bur-reed and pond weeds are often in the water itself while along the edges, roundfruit hedgehyssop and many species of Juncus are often found. A limited number of other aquatics such as water lily are sporadically distributed throughout. A good example of the moving water vegetation can be found in West Fork Sixmile Creek just downstream from Lookout Road (Section 29 T1N R6W). Fullerton Lake in Section 4 T1S R6W is a manmade body of water and is the best example of the nonmoving open water habitat in the Limited Use Area.

Disturbed areas can be found along the edges of roads and around old home sites or dump sites throughout the area. Species are almost all annual and non native. Commonly encountered species are crabgrass, Johnsongrass, Pensacola Bahiagrass, ragweeds, spurges, horseweed, dog fennel, bitterweed, morning glory, clovers, horse nettle, curly dock, and common goldenrod. Disturbed areas in the Limited Use Area are small and if not redisturbed, rapidly undergo succession toward one of the native vegetation types. A fairly typical disturbed area can be found along a small trail leading east off of Forest Service Road 403 in Section 21 T1S R8W.

\section{Rare and Endangered Species}

According to the latest listing by the Louisiana Department of Natural Heritage, 39 species of Rare and Endangered species are known from the Limited Use Area and/or Fort Polk and/or Vernon Parish (Table C3). Thirteen Rare and Endangered species are known from one or more locations in the Limited Use Area. All thirteen species (Burmannia biflora, Calopogon barbatus, Calopogon pallidus, Lachnocaulon digynum, Panicum tenerum, Platanthera integra, Rhynchospora macra, Rudbeckia scabrifolia, Sabatia macrophylla, Xyris drummondii, Xyris scabrifolia, Xyris stricta, and Zigadenus densus) are plants of bogs. This points out two facts: (1) The bog habitat is very important and all bogs in the Limited Use Area should be protected and (2) most botanical excursions and studies in the Limited Use Area have concentrated on bogs. 
Eleven of the Rare and Endangered Species are reported from Vernon Parish and 15 from Fort Polk. Many of these species are probably in the Limited Use Area and additional botanical excursions in the Limited Use Area will turn up records of most of these species. In the 1980's, yellowroot was discovered on Fort Polk. This is the latest woody native species to be discovered in the state and was a shocker. Most botanists believed that all woody plant species had already been documented for Louisiana. Yellowroot will probably be found in the Limited Use Area since the two known locations (in baygalls) are just north of the Fort Polk-Kisatchie National Forest Limited Use Area line. In 1996, the only native extant population of Marshallia trinervia in Louisiana was found on Fort Polk in the riparian forest along Bird's Creek within 100 yards of the Fort Polk-Limited Use Area boundary. Yellow Lady Slipper is known from only two locations in west central Louisiana. Both locations are in riparian forest habitats on Fort Polk. Thorough searches of these two habitats in the Limited Use Area should turn up records of these three species and other significant records. These records from Fort Polk point to the importance of Fort Polk as the habitat island in west central Louisiana.

\section{Scenic Stream Vegetation}

The vegetation along the scenic streams (Whiskey Chitto and the Sixmile Creeks) is primarily the riparian vegetation type. Immediately adjacent to the stream, the Whiskey Chitto vegetation tends to be more of an upland type while the vegetation immediately adjacent to the two Sixmile Creeks tends to be more toward the baygall type. Upslope from the two Sixmile Creeks, the vegetation is a typical upland riparian type. More upland species like sugar maple and eastern hophornbeam are found along Whiskey Chitto while wetter species like black gum and even bald cypress are found along the Sixmile Creeks. Further downstream beyond the Limited Use Area, the Sixmile Creeks vegetation does change into a more typical upland riparian vegetation type. Another difference between the two streams is in $\mathrm{pH}$; Whiskey Chitto probably has a higher (less acid) $\mathrm{pH}$ than the Sixmile Creeks. This prediction is based on the presence and abundance of acid preferring species like peat moss (Sphagnum) along the Sixmile Creeks and the paucity of it along Whiskey Chitto Creek.

The scenic stream vegetation contains the highest diversity (richness) of woody species in the Limited Use Area. When a complete analysis is done of the woody vegetation along these streams, the number of woody species will be high and will be comparable to that of other riparian areas in the state. The herbaceous vegetation along these streams will probably contain several Rare and Endangered species including perhaps yellowroot, yellow ladies slipper, Barbara's Buttons, and possibly other species that are not reported from the area or from the state.

Except for the species of disturbed areas, most species are found in more than one vegetation type. Thirty species are known only from the Riparian Forest (Table C4) and most of these are very limited in distribution. Riparian vegetation is present in narrow strips along the streams; thus many species of this vegetation type occur in small scattered patches. Because of the large number of species, limited distribution, and the potential for discovery of rare species; the riparian vegetation-especially that along the scenic streams-is a very important resource in the Limited Use area. 


\section{SELECTED REFERENCES}

ALLEN, C.M., C.H. STAGG, AND S.D. PARIS. 1987. Analysis of the vegetation in pitcher plant bogs in two baygalls at Fort Polk in west central Louisiana. Proc. La. Acad. Sci. 50:1-6.

ALLEN, C.M., C.H. STAGG, AND S.D. PARIS. 1990. Analysis of the herbaceous vegetation in two upland areas at Fort Polk in west central Louisiana. La. Environmental Professional 6:16-24.

ALLEN, C.M., H.D. GUILLORY, C.H. STAGG, S.D. PARIS, AND R.D. THOMAS. 1987. Yellowroot (Xanthorhiza simplicissima Marshall) New to Louisiana. Phytologia 62:5-6.

ALLEN, C.M., H.D. GUILLORY, C.H. STAGG, AND S.D. PARIS. 1990. The effects of sedimentation on the flora and vegetation of baygalls in west central Louisiana. Proc. La. Acad. Sci. 53:33-41.

ALLEN, C.M., H.D. GUILLORY, M.F. VIDRINE, C.H. STAGG, AND S.D. PARIS. 1990. Baygalls; Wildlife Havens. Louisiana Conservationist 42(6): 24-26.

ALLEN, C.M. AND H.D. GUILLORY. 1990. Effects of Military Activities on Longleaf Pine Forests Developed on Sandy Soils at Fort Polk. Prepared through a Purchase Order from Fort. Polk. Report on File at Environmental Section at Fort Polk.

ALLEN, C.M. 1996. Analysis of the Vegetation in and along East Fork Six Mile, West Fork Six Mile, and Bird's creeks on Fort Polk. Prepared for U.S. Geological Survey Water Resources Division, Louisiana District.

ALLEN, C.M. 1994. Calcareous Prairie Ecosystem on Fort Polk. Prepared through a consultant Agreement with Radian Corp. Report on File at Environmental Section at Fort Polk.

ALLEN, C.M. 1995. Calcareous Prairie Ecosystem on Fort Polk; Summary and Management Recommendations. Prepared through a consultant Agreement with Radian Corp. Report on File at Environmental Section at Fort Polk.

BOND, C.L., J.L. TINGLE, J.K. STOLL, AND C.M. ALLEN. 1987. Environmental monitoring of the advanced wastewater treatment facility, Fort. Polk, La. Preoperational site conditions, 1983-1984 and Postoperational site conditions 1985-86. U.S. Army Eng. Waterways Exp. Stat. Vicksburg, Miss.

HART, B.L. AND G.D. LESTER. 1993. Natural Community and Sensitive Species Assessment on Fort Polk Military Reservation, Louisiana. Louisiana Dept. of Wildlife and Fisheries, Baton Rouge.

JOHNSON, F.L., C.M. ALLEN, M.D. PROCTOR, R.A. THOMPSON, AND G.D. SCHNELL. 1993. Floral Inventory of Fort Polk, Louisiana. U.S. Army Construction Eng. Res. Lab. Final Report. 
Table C1. Plant Species, with Common Name and Family, from the Limited Use Area, Vernon Ranger District, Kisatchie National Forest, Louisiana

Plant Species

Acacia angustissima

Acalypha gracilens

Acalypha rhomboidea

Acanthospermum australe

Acer barbatum

Acer negundo

Acer rubrum var. drummondii

Acer rubrum var. rubrum

Acer saccharinum

Acer saccharum

Achillea millefolium

Acmella oppositifolia var. repens

Aeschynomene indica

Aesculus pavia

Agalinis fasciculata

Agalinis oligophylla

Agalinis pinetorum

Agalinis purpurea

Agalinis tenuifolia

Agalinis viridis

Ageratina altissima

Agrimonia microcarpa

Agrostis elliottiana

Agrostis hyemalis

Agrostis perennans var. perennans

Aira elegans

Albizia julibrissin

Aletris aurea

Aletris farinosa

Allium canadense var. canadense

Allium canadense var. mobilense

Alnus serrulata

Alopecurus carolinianus

Alophia drummondii

Alternanthera caracasana

Amaranthus viridis

Ambrosia artemisiifolia

Ambrosia bidentata

Ambrosia psilostachya

Ambrosia trifida
Common Name

PRAIRIE ACACIA

THREE-SEEDED MERCURY

THREE-SEEDED MERCURY

PARAGUAY BUR

SOUTHERN SUGAR MAPLE

BOXELDER

DRUMMOND RED MAPLE

RED MAPLE

SILVER MAPLE

SUGAR MAPLE

YARROW

CREEPING SPOTFLOWER

INDIAN JOINTVETCH

RED BUCKEYE

BEACH FALSE FOXGLOVE

RIDGESTEM FALSE FOXGLOVE

COASTALPLAIN FALSE FOXGLOVE

PURPLE FALSE FOXGLOVE

SLENDERLEAF FALSE FOXGLOVE

GREEN FALSE FOXGLOVE

WHITE SNAKE-ROOT

SMALLFRUIT AGRIMONY

ELLIOTT BENTGRASS

WINTER BENTGRASS

AUTUMN BENTGRASS

ANNUAL HAIRGRASS

MIMOSA

YELLOW COLIC-ROOT

WHITE COLIC-ROOT

CANADA ONION

PINK ONION

ALDER

CAROLINA FOXTAIL

PINE WOODS LILY

CHAFF-WEED

GREEN AMARANTH

COMMON RAGWEED

SOUTHERN RAGWEED

WESTERN RAGWEED

GIANT RAGWEED
Eamily

FABACEAE

EUPHORBIACEAE

EUPHORBIACEAE

ASTERACEAE

ACERACEAE

ACERACEAE

ACERACEAE

ACERACEAE

ACERACEAE

ACERACEAE

ASTERACEAE

ASTERACEAE

FABACEAE

HIPPOCASTANACEAE

SCROPHULARIACEAE

SCROPHULARIACEAE

SCROPHULARIACEAE

SCROPHULARIACEAE

SCROPHULARIACEAE

SCROPHULARIACEAE

ASTERACEAE

ROSACEAE

POACEAE

POACEAE

POACEAE

POACEAE

FABACEAE

LILIACEAE

LILIACEAE

LIIIACEAE

LILIACEAE

BETULACEAE

POACEAE

IRIDACEAE

AMARANTHACEAE

AMARANTHACEAE

ASTERACEAE

ASTERACEAE

ASTERACEAE

ASTERACEAE 
Table C1. Plant Species, with Common Name and Family, from the Limited Use Area, Vernon Ranger District, Kisatchie National Forest, Louisiana--Continued

\begin{tabular}{|c|c|c|}
\hline Plant Species & Common Name & Eamily \\
\hline Amelanchier arborea & COMMON SERVICEBERRY & ROSACEAE \\
\hline Ammannia coccinea & VALLEY REDSTEM & LYTHRACEAE \\
\hline Amorpha paniculata & LEADPLANT & FABACEAE \\
\hline Ampelopsis arborea & PEPPERVINE & VITACEAE \\
\hline Amsonia ludoviciana & LOUISIANA BLUESTAR & APOCYNACEAE \\
\hline Amsonia rigida & NARROW-LEAF BLUESTAR & APOCYNACEAE \\
\hline Amsonia tabernaemontana & BLUESTAR & APOCYNACEAE \\
\hline Anagallis arvensis & SCARLET PIMPERNEL & PRIMULACEAE \\
\hline Anagallis minima & CHAFFWEED & PRIMULACEAE \\
\hline Andropogon gerardii & BIG BLUESTEM & POACEAE \\
\hline \multicolumn{3}{|l|}{ Andropogon glomeratus } \\
\hline var. glomeratus & BUSHY BEARDGRASS & POACEAE \\
\hline \multicolumn{3}{|l|}{ Andropogon gyrans } \\
\hline var. gyrans & ELLIOTT'S BLUESTEM & POACEAE \\
\hline \multicolumn{3}{|l|}{ Andropogon liebmannii } \\
\hline var. pungensis & MOHR'S BLUESTEM & POACEAE \\
\hline Andropogon ternarius & SPLIT-BEARD BLUESTEM & POACEAE \\
\hline \multicolumn{3}{|l|}{ Andropogon virginicus } \\
\hline var. virginicus & BROOMSEDGE & POACEAE \\
\hline Antennaria parlinii ssp. fallax & PUSSYTOES & ASTERACEAE \\
\hline Anthaenantia rufa & PURPLE SILKYSCALE & POACEAE \\
\hline Anthaenantia villosa & GREEN SILKYSCALE & POACEAE \\
\hline Apios americana & GROUND NUT & FABACEAE \\
\hline Apocynum cannabinum & INDIAN HEMP & APOCYNACEAE \\
\hline Apteria aphylla & NODDING NIXIE & BURMANNIACEAE \\
\hline Aralia spinosa & HERCULES' CLUB & ARALIACEAE \\
\hline Arisaema dracontium & GREEN DRAGON & ARACEAE \\
\hline Arisaema triphyllum & JACK-IN-THE-PULPIT & ARACEAE \\
\hline \multicolumn{3}{|l|}{ Arisaema triphyllum } \\
\hline ssp. pusillum & JACK-IN-THE-PULPIT & ARACEAE \\
\hline \multicolumn{3}{|l|}{ Arisaema triphyllum } \\
\hline ssp. quinatum & JACK-IN-THE-PULPIT & ARACEAE \\
\hline Aristida dichotoma & CHURCHMOUSE THREE-AWN & POACEAE \\
\hline Aristida lanosa & WOOLY THREE-AWN & POACEAE \\
\hline \multicolumn{3}{|l|}{ Aristida longespica } \\
\hline var. geniculata & SLIMSPIKE THREE-AWN & POACEAE \\
\hline \multicolumn{3}{|l|}{ Aristida longespica } \\
\hline var. longespica & SLIMSPIKE THREE-AWN & POACEAE \\
\hline Aristida oligantha & OLDFIELD THREE-AWN & POACEAE \\
\hline Aristida palustris & LONGLEAF THREE-AWN & POACEAE \\
\hline \multicolumn{3}{|l|}{ Aristida purpurascens } \\
\hline var. purpurascens & ARROWFEATHER THREE-AWN & POACEAE \\
\hline Aristida purpurascens var. virgata & PINEWOODS THREE-AWN & POACEAE \\
\hline Aristida ramosissima & S-CURVE THREE-AWN & POACEAE \\
\hline Aristolochia reticulata & HAIRY DUTCHMAN'S PIPE & ARISTILOCHIACEAE \\
\hline
\end{tabular}


Table C1. Plant Species, with Common Name and Family, from the Limited Use Area, Vernon Ranger District, Kisatchie National Forest, Louisiana--Continued

\begin{tabular}{|c|c|c|}
\hline Plant Species & Common Name & Eamily \\
\hline Aristolochia serpentaria & VIRGINIA DUTCHMAN'S PIPE & ARISTILOCHIACEAE \\
\hline Aristolochia tomentosa & DUTCHMAN'S PIPE VINE & ARISTILOCHIACEAE \\
\hline Aronia arbutifolia & CHOKECHERRY & ROSACEAE \\
\hline Arundinaria gigantea ssp. gigantea & GLANT CANE & POACEAE \\
\hline Asclepias amplexicaulis & BLUNT-LEAVED MILKWEED & ASCLEPIADACEAE \\
\hline Asclepias longifolia & LONGLEAF MILKWEED & ASCLEPIADACEAE \\
\hline Asclepias obovata & SAVANNAH MILKWEED & ASCLEPIADACEAE \\
\hline Asclepias perennis & SHORE MILKWEED & ASCLEPIADACEAE \\
\hline Asclepias rubra & RED MILKWEED & ASCLEPIADACEAE \\
\hline Asclepias tuberosa & BUTTERFLY-WEED & ASCLEPIADACEAE \\
\hline Asclepias variegata & WHITE-FLOWERED MILKWEED & ASCLEPIADACEAE \\
\hline Asclepias verticillata & WHORLED MILKWEED & ASCLEPIADACEAE \\
\hline Asclepias viridiflora & GREEN-FLOWERED MILKWEED & ASCLEPIADACEAE \\
\hline Asclepias viridis & ANTELOPE-HORN & ASCLEPIADACEAE \\
\hline Asimina parviflora & DWARF PAWPAW & ANNONACEAE \\
\hline Asimina triloba & PAWPAW & ANNONACEAE \\
\hline Asplenium platyneuron & EBONY SPLEENWORT & ASPLENIACEAE \\
\hline \multicolumn{3}{|l|}{ Aster drummondii } \\
\hline var. drummondii & DRUMMOND'S ASTER & ASTERACEAE \\
\hline Aster dumosus & BUSHY ASTER & ASTERACEAE \\
\hline Aster fragilis & ASTER & ASTERACEAE \\
\hline Aster lanceolatus & ASTER & ASTERACEAE \\
\hline Aster lateriflorus & CALICO ASTER & ASTERACEAE \\
\hline \multicolumn{3}{|l|}{ Aster paludosus } \\
\hline ssp. hemisphericus & SHOWY ASTER & ASTERACEAE \\
\hline Aster patens var. patens & LATE ASTER & ASTERACEAE \\
\hline Aster pilosus & FROSTWEED & ASTERACEAE \\
\hline Aster sericeus var. microphyllus & SILKY ASTER & ASTERACEAE \\
\hline Aster subulatus var. ligulatus & ANNUAL ASTER & ASTERACEAE \\
\hline Aster subulatus var. subulatus & ANNUAL ASTER & ASTERACEAE \\
\hline Aster umbellatus var. latifolius & BAYGALL WHITE ASTER & ASTERACEAE \\
\hline Athyrium filix-femina & SOUTHERN LADY FERN & WOODSIACEAE \\
\hline \multirow[t]{2}{*}{ Aureolaria flava } & SMOOTH YELLOW & \\
\hline & FALSE FOXGLOVE & SCROPHULARIACEAE \\
\hline \multirow[t]{2}{*}{ Aureolaria grandiflora } & LARGEFLOWER YELLOW & \\
\hline & FALSE FOXGLOVE & SCROPHULARIACEAE \\
\hline \multirow[t]{2}{*}{ Aureolaria pectinata } & COMBLEAF YELLOW & \\
\hline & FALSE FOXGLOVE & SCROPHULARIACEAE \\
\hline \multirow[t]{2}{*}{ Aureolaria virginica } & DOWNY YELLOW & \\
\hline & FALSE FOXGLOVE & SCROPHULARIACEAE \\
\hline Avena sativa & COMMON OATS & POACEAE \\
\hline Axonopus affinis & COMMON CARPETGRASS & POACEAE \\
\hline Axonopus furcatus & BIG CARPETGRASS & POACEAE \\
\hline Baccharis halimifolia & SALTBUSH & ASTERACEAE \\
\hline
\end{tabular}


Table C1. Plant Species, with Common Name and Family, from the Limited Use Area, Vernon Ranger District, Kisatchie National Forest, Louisiana--Continued

\begin{tabular}{|c|c|c|}
\hline Plant Species & Common Name & Eamily \\
\hline Bacopa caroliniana & BLUE WATERHYSSOP & SCROPHULARIACEAE \\
\hline Baptisia alba var. macrophylla & WHITE WILD INDIGO & FABACEAE \\
\hline \multicolumn{3}{|l|}{ Baptisia bracteata } \\
\hline var. laevicaulis & LONGBRACT WILD INDIGO & FABACEAE \\
\hline \multicolumn{3}{|l|}{ Baptisia bracteata } \\
\hline var. leucophaea & LONGBRACT WILD INDIGO & FABACEAE \\
\hline Baptisia nuttalliana & NUTTALL'S WILD INDIGO & FABACEAE \\
\hline Bartonia paniculata & TWINING SCREWSTEM & GENTIANACEAE \\
\hline Berchemia scandens & RATTAN VINE & RHAMNACEAE \\
\hline Berlandiera pumila & SPOT GREENEYES & ASTERACEAE \\
\hline \multicolumn{3}{|l|}{ Berlandiera } \\
\hline $\mathrm{x}$ betonicifolia & HAIRY GREENEYES & ASTERACEAE \\
\hline Betula nigra & RIVER BIRCH & BETULACEAE \\
\hline Bidens aristosa & BEARDED BEGGAR'S TICKS & ASTERACEAE \\
\hline Bidens bipinnata & SPANISH NEEDLES & ASTERACEAE \\
\hline Bidens discoidea & FLOATING-LOG BEGGAR'S TICKS & ASTERACEAE \\
\hline Bidens frondosa & DEVIL'S BEGGAR'S TICKS & ASTERACEAE \\
\hline Bigelowia nuttallii & RAYLESS GOLDENROD & ASTERACEAE \\
\hline Bignonia capreolata & CROSS-VINE & BIGNONIACEAE \\
\hline Boehmeria cylindrica & SMALLSPIKE FALSENETTLE & URTICACEAE \\
\hline Boerhaavia erecta & ERECT SPIDERLING & NYCTAGINACEAE \\
\hline Boltonia diffusa & SMALLHEAD DOLL'S DAISY & ASTERACEAE \\
\hline Bothriochloa ischaemum & KINGRANCH BLUESTEM & POACEAE \\
\hline \multicolumn{3}{|l|}{ Bothriochloa laguroides } \\
\hline ssp. torreyana & SILVER BLUESTEM & POACEAE \\
\hline Botrychium biternatum & SPARSE-LOBED GRAPE FERN & OPHIOGLOSSACEAE \\
\hline Botrychium virginianum & RATTLESNAKE FERN & OPHIOGLOSSACEAE \\
\hline Brachiaria platyphylla & BROADLEAF SIGNALGRASS & POACEAE \\
\hline Brachyelytrum erectum & BEARDED SHORTHUSK & POACEAE \\
\hline Brasenia schreberi & WATER SHIELD & CABOMBACEAE \\
\hline Brassica juncea & INDIAN MUSTARD & BRASSICACEAE \\
\hline Brickellia eupatorioides & FALSE BONESET & ASTERACEAE \\
\hline Briza minor & LITTLE QUAKINGGRASS & POACEAE \\
\hline Bromus japonicus & JAPANESE BROMEGRASS & POACEAE \\
\hline Bromus pubescens & CANADA BROMEGRASS & POACEAE \\
\hline Bromus racemosus & HAIRY BROMEGRASS & POACEAE \\
\hline Bromus tectorum & DOWNY BROMEGRASS & POACEAE \\
\hline Bromus unioloides & RESCUEGRASS & POACEAE \\
\hline Brunnichia ovata & LADIES EARDROP VINE & POLYGONACEAE \\
\hline Buchnera americana & BLUEHEARTS & SCROPHULARIACEAE \\
\hline Bulbostylis barbata & HAIR-SEDGE & CYPERACEAE \\
\hline
\end{tabular}


Table C1. Plant Species, with Common Name and Family, from the Limited Use Area, Vernon Ranger District, Kisatchie National Forest, Louisiana--Continued

\begin{tabular}{|c|c|c|}
\hline Plant Species & Common Name & Eamily \\
\hline Bulbostylis capillaris & HAIR-SEDGE & CYPERACEAE \\
\hline Bulbostylis ciliatifolia & HAIR-SEDGE & CYPERACEAE \\
\hline Bumelia lanuginosa & GUM BULLY & SAPOTACEAE \\
\hline Bumelia lycioides & BUCKTHORN BULLY & SAPOTACEAE \\
\hline Burmannia biflora & BLUE BURMANNIA & BURMANNIACEAE \\
\hline Burmannia capitata & BURMANNIA & BURMANNIACEAE \\
\hline Cabomba caroliniana & FANWORT & CABOMBACEAE \\
\hline Cacalia ovata & INDIAN PLANTAIN & ASTERACEAE \\
\hline Cacalia plantaginea & TUBEROUS INDIAN PLANTAIN & ASTERACEAE \\
\hline Callicarpa americana & AMERICAN BEAUTYBERRY & VERBENACEAE \\
\hline Callirhoe papaver & WINECUP & MALVACEAE \\
\hline Callitriche heterophylla & WATER STARWORT & CALLITRICHACEAE \\
\hline Callitriche nuttallii & TERRESTRIAL STARWORT & CALLITRICHACEAE \\
\hline Callitriche peploides & TERRESTIAL STARWORT & CALLITRICHACEAE \\
\hline Calopogon barbatus & BEARDED GRASS-PINK & ORCHIDACEAE \\
\hline Calopogon pallidus & PALE GRASS-PINK & ORCHIDACEAE \\
\hline Calopogon tuberosus & COMMON GRASS-PINK & ORCHIDACEAE \\
\hline Calyptocarpus vialis & STRAGGLER DAISY & ASTERACEAE \\
\hline Camelina microcarpa & SMALLSEED FALSEFLAX & BRASSICACEAE \\
\hline Campsis radicans & TRUMPET CREEPER & BIGNONIACEAE \\
\hline Cardamine bulbosa & BULBOUS BITTER CRESS & BRASSICACEAE \\
\hline Cardamine hirsuta & HAIRY BITTER CRESS & BRASSICACEAE \\
\hline Cardamine parviflora & SAND BITTERCRESS & BRASSICACEAE \\
\hline Carex alata & WINGSEED CARIC SEDGE & CYPERACEAE \\
\hline Carex albolutescens & GREENISH-WHITE CARIC SEDGE & CYPERACEAE \\
\hline Carex amphibola & NARROWLEAF CARIC SEDGE & CYPERACEAE \\
\hline Carex atlantica & EASTERN CARIC SEDGE & CYPERACEAE \\
\hline Carex caroliniana & CAROLINA CARIC SEDGE & CYPERACEAE \\
\hline Carex cephalophora & WOODBANK CARIC SEDGE & CYPERACEAE \\
\hline Carex cherokeensis & CHEROKEE CARIC SEDGE & CYPERACEAE \\
\hline Carex comosa & BRISTLY CARIC SEDGE & CYPERACEAE \\
\hline Carex complanata & CARIC SEDGE & CYPERACEAE \\
\hline Carex corrugata & CARIC SEDGE & CYPERACEAE \\
\hline Carex crebriflora & CARIC SEDGE & CYPERACEAE \\
\hline Carex debilis & SPINDLEFRUIT CARIC SEDGE & CYPERACEAE \\
\hline Carex digitalis & WOOD CARIC SEDGE & CYPERACEAE \\
\hline Carex flaccosperma & THIN-FRUIT CARIC SEDGE & CYPERACEAE \\
\hline Carex folliculata & BLADDER CARIC SEDGE & CYPERACEAE \\
\hline Carex frankii & FRANK'S CARIC SEDGE & CYPERACEAE \\
\hline Carex glaucescens & CLUSTERED SEDGE & CYPERACEAE \\
\hline
\end{tabular}


Table C1. Plant Species, with Common Name and Family, from the Limited Use Area, Vernon Ranger District, Kisatchie National Forest, Louisiana--Continued

\begin{tabular}{|c|c|c|}
\hline Plant Species & Common Name & Eamily \\
\hline Carex glaucodea & SOUTHERN CARIC SEDGE & CYPERACEAE \\
\hline Carex howei & CARIC SEDGE & CYPERACEAE \\
\hline Carex intumescens & COMMON BLADDER CARIC SEDGE & CYPERACEAE \\
\hline Carex joorii & HUMMOCK CARIC SEDGE & CYPERACEAE \\
\hline Carex leptalea & THREADSTEM CARIC SEDGE & CYPERACEAE \\
\hline Carex longii & LONG'S CARIC SEDGE & CYPERACEAE \\
\hline Carex lurida & SUMMER CARIC SEDGE & CYPERACEAE \\
\hline Carex microdonta & LITTLETOOTH CARIC SEDGE & CYPERACEAE \\
\hline Carex muhlenbergii & MUHLENBERG'S CARIC SEDGE & CYPERACEAE \\
\hline Carex nigromarginata & CARIC SEDGE & CYPERACEAE \\
\hline Carex oxylepis & SHARPSCALE CARIC SEDGE & CYPERACEAE \\
\hline Carex rosea & STELLATE CARIC SEDGE & CYPERACEAE \\
\hline Carex tenax & CARIC SEDGE & CYPERACEAE \\
\hline Carex tribuloides & BRISTLE-BRACT CARIC SEDGE & CYPERACEAE \\
\hline Carex verrucosa & CARIC SEDGE & CYPERACEAE \\
\hline Carpinus caroliniana & BLUE BEECH & BETULACEAE \\
\hline Carya alba & MOCKERNUT HICKORY & JUGLANDACEAE \\
\hline Carya aquatica & WATER HICKORY & JUGLANDACEAE \\
\hline Carya cordiformis & BITTERNUT HICKORY & JUGLANDACEAE \\
\hline Carya glabra & PIGNUT HICKORY & JUGLANDACEAE \\
\hline Carya glabra var. hirsuta & PIGNUT HICKORY & JUGLANDACEAE \\
\hline Carya illinoensis & PECAN & JUGLANDACEAE \\
\hline Carya myristicaeformis & NUTMEG HICKORY & JUGLANDACEAE \\
\hline Carya ovata & SHAGBARK HICKORY & JUGLANDACEAE \\
\hline Carya texana & BLACK HICKORY & JUGLANDACEAE \\
\hline Cassia fasciculata & PARTRIDGE PEA & FABACEAE \\
\hline Cassia marilandica & MARYLAND COFFEE WEED & FABACEAE \\
\hline Cassia nictitans & PARTRIDGE PEA & FABACEAE \\
\hline Cassia occidentalis & SEPTICWEED & FABACEAE \\
\hline Castanea pumila & CHINQUAPIN & FAGACEAE \\
\hline Catalpa bignonioides & SOUTHERN CATALPA & BIGNONIACEAE \\
\hline Ceanothus americanus & NEW JERSEY TEA & RHAMNACEAE \\
\hline Celtis laevigata & HACKBERRY & ULMACEAE \\
\hline \multicolumn{3}{|l|}{ Celtis laevigata } \\
\hline var. reticulata & NETLEAF HACKBERRY & ULMACEAE \\
\hline Celtis tenuifolia & DWARF HACKBERRY & ULMACEAE \\
\hline Cenchrus incertus & COAST SANDBUR & POACEAE \\
\hline Centella erecta & SPADELEAF & APIACEAE \\
\hline Centrosema virginiana & SPURRED BUTTERFLY PEA & FABACEAE \\
\hline Cephalanthus occidentalis & BUTTONBUSH & RUBIACEAE \\
\hline Cerastium glomeratum & MOUSE-EAR CHICKWEED & CARYOPHYLLACEAE \\
\hline
\end{tabular}


Table C1. Plant Species, with Common Name and Family, from the Limited Use Area, Vernon Ranger District, Kisatchie National Forest, Louisiana--Continued

\begin{tabular}{|c|c|c|}
\hline Plant Species & Common Name & Eamily \\
\hline Ceratophyllum demersum & COONTAIL & CERATOPHYLLACEAE \\
\hline Cercis canadensis & REDBUD & FABACEAE \\
\hline Chaerophyllum tainturieri & WILD CHERVIL & APIACEAE \\
\hline Chamaesyce cordifolia & HEART-LEAF SPURGE & EUPHORBIACEAE \\
\hline Chamaesyce maculata & SPOTTED SPURGE & EUPHORBIACEAE \\
\hline Chamaesyce nutans & EYE-BANE & EUPHORBIACEAE \\
\hline Chamaesyce serpens & MAT SPURGE & EUPHORBIACEAE \\
\hline Chaptalia tomentosa & SUN-BONNETS & ASTERACEAE \\
\hline Chasmanthium latifolium & INLAND SEAOATS & POACEAE \\
\hline Chasmanthium laxum & BROADLEAF UNIOLA & POACEAE \\
\hline Chasmanthium sessiliflorum & NARROWLEAF WOOD OATS & POACEAE \\
\hline Chenopodium ambrosioides & MEXICAN TEA & CHENOPODIACEAE \\
\hline Chionanthus virginica & FRINGE TREE & OLEACEAE \\
\hline Chloris virgata & FEATHER FINGERGRASS & POACEAE \\
\hline Chrysopsis graminifolia & GRASSLEAF GOLDENASTER & ASTERACEAE \\
\hline Chrysopsis mariana & MARYLAND GOLDENASTER & ASTERACEAE \\
\hline Chrysopsis pilosa & HOARY GOLDENASTER & ASTERACEAE \\
\hline Ciclospermum leptophyllum & SLIMLOBE CELERY & APIACEAE \\
\hline Cirsium carolinianum & CAROLINA THISTLE & ASTERACEAE \\
\hline Cirsium horridulum & HORRID THISTLE & ASTERACEAE \\
\hline Claytonia virginica & SPRING BEAUTY & PORTULACEAE \\
\hline Cleistes divaricata & SPREADING POGONIA & ORCHIDACEAE \\
\hline Clematis crispa & SWAMP LEATHER FLOWER & RANUNCULACEAE \\
\hline Clematis reticulata & NETLEAF LEATHER FLOWER & RANUNCULACEAE \\
\hline Clematis terniflora & SWEET AUTUMN VIRGINSBOWER & RANUNCULACEAE \\
\hline Clematis virginiana & DEVIL'S DARNING NEEDLES & RANUNCULACEAE \\
\hline Cleome hassleriana & SPIDER LEGS & CAPPARACEAE \\
\hline Clitoria mariana & BUTTERFLY PEA & FABACEAE \\
\hline Cnidoscolus texanus & LARGE BULL NETTLE & EUPHORBIACEAE \\
\hline Cocculus carolina & CAROLINA SNAILSEED & MENISPERMACEAE \\
\hline Coelorachis cylindrica & CAROLINA JOINTGRASS & POACEAE \\
\hline Coelorachis rugosa & WRINKLED JOINTGRASS & POACEAE \\
\hline Colocasia antiquorum & ELEPHANTS EAR & ARACEAE \\
\hline Commelina communis & COMMON DAYFLOWER & COMMELINACEAE \\
\hline Commelina diffusa & WIDOW'S TEARS & COMMELINACEAE \\
\hline Commelina erecta & NARROWLEAF DAYFLOWER & COMMELINACEAE \\
\hline Commelina virginica & BROAD-LEAF DAYFLOWER & COMMELINACEAE \\
\hline Conyza bonariensis & LARGE-HEAD HORSEWEED & ASTERACEAE \\
\hline Conyza canadensis var. canadensis & HORSEWEED & ASTERACEAE \\
\hline Conyza canadensis var. pusilla & SMALL-HEAD HORSEWEED & ASTERACEAE \\
\hline
\end{tabular}


Table C1. Plant Species, with Common Name and Family, from the Limited Use Area, Vernon Ranger District, Kisatchie National Forest, Louisiana--Continued

\begin{tabular}{|c|c|c|}
\hline Plant Species & Common Name & Eamily \\
\hline Coreopsis gladiata & TICKSEED & ASTERACEAE \\
\hline Coreopsis lanceolata & COMMON TICKSEED & ASTERACEAE \\
\hline Coreopsis linifolia & BOG TICKSEED & ASTERACEAE \\
\hline Coreopsis pubescens & STAR TICKSEED & ASTERACEAE \\
\hline Coreopsis tinctoria & PAINTED TICKSEED & ASTERACEAE \\
\hline Coreopsis tripteris & TALL TICKSEED & ASTERACEAE \\
\hline Cornus drummondii & ROUGH-LEAF DOGWOOD & CORNACEAE \\
\hline Cornus florida & FLOWERING DOGWOOD & CORNACEAE \\
\hline Cornus foemina & SWAMP DOGWOOD & CORNACEAE \\
\hline Coronopus didymus & SWINE CRESS & BRASSICACEAE \\
\hline Cortaderia dioica & PAMPASGRASS & POACEAE \\
\hline Crataegus berberifolia & BARBERRY HAWTHORN & ROSACEAE \\
\hline Crataegus brachyacantha & BLUEBERRY HAWTHORN & ROSACEAE \\
\hline Crataegus crus-gallii & COCKS-SPUR HAWTHORN & ROSACEAE \\
\hline Crataegus marshallii & PARSLEY HAWTHORN & ROSACEAE \\
\hline Crataegus opaca & MAYHAW & ROSACEAE \\
\hline Crataegus spathulata & LITTLEHIP HAWTHORN & ROSACEAE \\
\hline Crataegus uniflora & DWARF HAWTHORN & ROSACEAE \\
\hline Crataegus viridis & GREEN HAWTHORN & ROSACEAE \\
\hline Croptilon divaricatum & SCRATCH DAISY & ASTERACEAE \\
\hline Crotalaria lanceolata & ETHIOPIAN RATTLEBOX & FABACEAE \\
\hline Crotalaria sagittalis & ARROWHEAD RATTLEBOX & FABACEAE \\
\hline Croton argyranthemus & SILVER-LEAF CROTON & EUPHORBIACEAE \\
\hline Croton capitatus & GOATWEED, WOOLY CROTON & EUPHORBIACEAE \\
\hline Croton glandulosus & TROPIC CROTON & EUPHORBIACEAE \\
\hline Croton michauxii & NARROWLEAF RUSHFOIL & EUPHORBIACEAE \\
\hline Croton monanthogynus & ONE-SEED CROTON, PRAIRIE TEA & EUPHORBIACEAE \\
\hline Croton willdenowii & RUSHFOIL & EUPHORBIACEAE \\
\hline Ctenium aromaticum & TOOTHACHEGRASS & POACEAE \\
\hline Cuphea carthagenensis & COLOMBIAN WAXWEED & LYTHRACEAE \\
\hline Cuscuta compacta & DODDER & CUSCUTACEAE \\
\hline Cynodon dactylon & BERMUDAGRASS & POACEAE \\
\hline Cynoglossum virginianum & HOUND'S TONGUE & BORAGINACEAE \\
\hline Cyperus acuminatus & TAPERLEAF FLATSEDGE & CYPERACEAE \\
\hline Cyperus albomarginatus & WHITE-EDGE FLATSEDGE & CYPERACEAE \\
\hline Cyperus brevifolius & SHORTLEAF FLATSEDGE & CYPERACEAE \\
\hline Cyperus compressus & POORLAND FLATSEDGE & CYPERACEAE \\
\hline Cyperus erythrorhizos & REDROOT FLATSEDGE & CYPERACEAE \\
\hline \multicolumn{3}{|l|}{ Cyperus flavescens } \\
\hline var. flavescens & YELLOW FLATSEDGE & CYPERACEAE \\
\hline Cyperus globulosus & GLOBE FLATSEDGE & CYPERACEAE \\
\hline
\end{tabular}


Table C1. Plant Species, with Common Name and Family, from the Limited Use Area, Vernon Ranger District, Kisatchie National Forest, Louisiana--Continued

\begin{tabular}{|c|c|c|}
\hline Plant Species & Common Name & Eamily \\
\hline Cyperus grayioides & DEEP SAND FLATSEDGE & CYPERACEAE \\
\hline Cyperus haspan & SOFort FLAT-SEDGE & CYPERACEAE \\
\hline Cyperus iria & RICEFIELD FLATSEDGE & CYPERACEAE \\
\hline Cyperus odoratus & FRAGRANT FLATSEDGE & CYPERACEAE \\
\hline \multicolumn{3}{|l|}{ Cyperus ovularis } \\
\hline var. ovularis & GLOBE FLATSEDGE & CYPERACEAE \\
\hline \multicolumn{3}{|l|}{ Cyperus polystachyos } \\
\hline var. polystachyos & FLATSEDGE & CYPERACEAE \\
\hline \multicolumn{3}{|l|}{ Cyperus polystachyos } \\
\hline var. texensis & TEXAS FLATSEDGE & CYPERACEAE \\
\hline Cyperus pseudovegetus & KNOB FLATSEDGE & CYPERACEAE \\
\hline Cyperus reflexus & BENTAWN FLATSEDGE & CYPERACEAE \\
\hline Cyperus retrofractus & ROUGH FLATSEDGE & CYPERACEAE \\
\hline Cyperus retrorsus & CYLINDRIC FLATSEDGE & CYPERACEAE \\
\hline Cyperus rotundus & PURPLE NUTSEDGE & CYPERACEAE \\
\hline Cyperus sesquiflorus & LOW FLATSEDGE & CYPERACEAE \\
\hline Cyperus strigosus & FALSE NUTSEDGE & CYPERACEAE \\
\hline Cyperus surinamensis & TROPICAL FLATSEDGE & CYPERACEAE \\
\hline Cyperus tenuifolius & LAWN FLATSEDGE & CYPERACEAE \\
\hline Cyperus uniflorus & ONEFLOWER FLATSEDGE & CYPERACEAE \\
\hline Cyperus virens & GREEN FLATSEDGE & CYPERACEAE \\
\hline Cypripedium kentuckiense & YELLOW LADY SLIPPER & ORCHIDACEAE \\
\hline Cyrilla racemiflora & TITI & CYRILLACEAE \\
\hline Dactylis glomerata & ORCHARDGRASS & POACEAE \\
\hline Dalea candida & WHITE PRAIRIECLOVER & FABACEAE \\
\hline Dalea purpurea & PURPLE PRAIRIECLOVER & FABACEAE \\
\hline Danthonia spicata & POVERTY OATGRASS & POACEAE \\
\hline Datura stramonium & JIMSON WEED & SOLANACEAE \\
\hline Daucus pusillus & AMERICAN WILD CARROT & APIACEAE \\
\hline Delphenium vimineum & CAROLINA LARKSPUR & RANUNCULACEAE \\
\hline Delphinium carolinianum & CAROLINA LARKSPUR & RANUNCULACEAE \\
\hline Desmanthus illinoiensis & ILLINOIS BUNDLEFLOWER & FABACEAE \\
\hline Desmodium ciliare & HAIRY SMALLLEAF TICKTREFOIL & FABACEAE \\
\hline Desmodium glabellum & DILLENIUS'TICKTREFOII & FABACEAE \\
\hline Desmodium glutinosum & POINTEDLEAF TICKTREFOIL & FABACEAE \\
\hline Desmodium laevigatum & SMOOTH TICKTREFOIL & FABACEAE \\
\hline Desmodium lineatum & SAND TICKTREFOIL & FABACEAE \\
\hline Desmodium nudiflorum & NAKED FLOWER TICKTREFOIL & FABACEAE \\
\hline Desmodium obtusum & STIFF TICKTREFOIL & FABACEAE \\
\hline Desmodium paniculatum & PANICLEDLEAF TICKTREFOIL & FABACEAE \\
\hline Desmodium pauciflorum & FEWFLOWER TICKTREFOIL & FABACEAE \\
\hline
\end{tabular}


Table C1. Plant Species, with Common Name and Family, from the Limited Use Area, Vernon Ranger District, Kisatchie National Forest, Louisiana--Continued

\begin{tabular}{|c|c|c|}
\hline Plant Species & Common Name & Eamily \\
\hline Desmodium rotundifolium & PROSTRATE TICKTREFOIL & FABACEAE \\
\hline Desmodium strictum & PINEBARREN TICKTREFOIL & FABACEAE \\
\hline Desmodium viridiflorum & VELVETLEAF TICKTREFOIL & FABACEAE \\
\hline Dichondra caroliniensis & PONY FOOT & CONVOLVULACEAE \\
\hline Dichromena colorata & WHITETOP SEDGE & CYPERACEAE \\
\hline Dichromena latifolia & LARGE WHITETOP SEDGE & CYPERACEAE \\
\hline Dicliptera brachiata & BRANCHING FOLDWING & ACANTHACEAE \\
\hline Digitaria ciliaris & SOUTHERN CRABGRASS & POACEAE \\
\hline Digitaria filiformis & SLENDER CRABGRASS & POACEAE \\
\hline Digitaria ischaemum & SMOOTH CRABGRASS & POACEAE \\
\hline Digitaria sanguinalis & HAIRY CRABGRASS & POACEAE \\
\hline Digitaria villosa & SHAGGY CRABGRASS & POACEAE \\
\hline Digitaria violascens & VIOLET CRABGRASS & POACEAE \\
\hline Diodia teres & POOR JOE & RUBIACEAE \\
\hline Diodia virginiana & VIRGINIA BUTTONWEED & RUBIACEAE \\
\hline Dioscorea villosa & WILD YAM & DIOSCOREACEAE \\
\hline Diospyros virginiana & PERSIMMON & EBENACEAE \\
\hline Draba brachycarpa & WHITLOW-GRASS & BRASSICACEAE \\
\hline Dracopsis amplexicaulis & CLASPING CONEFLOWER & ASTERACEAE \\
\hline Drosera brevifolia & SUNDEW & DROSERACEAE \\
\hline Drosera capillaris & SUNDEW & DROSERACEAE \\
\hline Drymaria cordata & DRYMARIA & CARYOPHYLLACEAE \\
\hline Duchesnea indica & WILD STRAWBERRY & ROSACEAE \\
\hline \multirow[t]{2}{*}{ Echinacea angustifolia } & NARROW-LEAF PURPLE & \\
\hline & CONEFLOWER & ASTERACEAE \\
\hline Echinacea pallida & PALE PURPLE CONEFLOWER & ASTERACEAE \\
\hline Echinacea purpurea & PURPLE CONEFLOWER & ASTERACEAE \\
\hline Echinacea sanguinea & PALE PURPLE CONEFLOWER & ASTERACEAE \\
\hline Echinochloa colona & JUNGLERICE & POACEAE \\
\hline Echinochloa crus-galli & BARNYARDGRASS & POACEAE \\
\hline Echinochloa walteri & WATER MILLET & POACEAE \\
\hline Echinodorus cordifolius & CREEPING BURHEAD & ALISMATACEAE \\
\hline Eclipta prostrata & PIE PLANT & ASTERACEAE \\
\hline Egeria densa & SOUTHERN ELODEA & HYDROCHARITACEAE \\
\hline Eichhornia crassipes & WATER HYACINTH & PONTEDERIACEAE \\
\hline Eleocharis baldwinii & BALDWIN SPIKESEDGE & CYPERACEAE \\
\hline Eleocharis elliptica & FLATTENED SPIKESEDGE & CYPERACEAE \\
\hline Eleocharis equisetoides & HORSETAIL SPIKESEDGE & CYPERACEAE \\
\hline Eleocharis flavescens & PALE SPIKESEDGE & CYPERACEAE \\
\hline Eleocharis microcarpa & SMALLSEED SPIKESEDGE & CYPERACEAE \\
\hline Eleocharis obtusa & COMMON SPIKESEDGE & CYPERACEAE \\
\hline
\end{tabular}


Table C1. Plant Species, with Common Name and Family, from the Limited Use Area, Vernon Ranger District, Kisatchie National Forest, Louisiana--Continued

\begin{tabular}{|c|c|c|}
\hline Plant Species & Common Name & Eamily \\
\hline Eleocharis quadrangulata & SQUARESTEM SPIKESEDGE & CYPERACEAE \\
\hline Eleocharis tortilis & TWISTED SPIKESEDGE & CYPERACEAE \\
\hline Eleocharis tuberculosa & CONECUP SPIKESEDGE & CYPERACEAE \\
\hline Elephantopus carolinianus & ELEPHANT'S FOOT & ASTERACEAE \\
\hline Elephantopus nudatus & PURPLE ELEPHANT'S FOOT & ASTERACEAE \\
\hline Elephantopus tomentosus & ELEPHANT'S FOOT & ASTERACEAE \\
\hline Eleusine indica & GOOSEGRASS & POACEAE \\
\hline Elymus virginicus & VIRGINIA WILDRYE & POACEAE \\
\hline Epifagus virginiana & BEECH DROPS & OROBANCHACEAE \\
\hline Eragrostis cilianensis & STINKGRASS & POACEAE \\
\hline Eragrostis ciliaris & GOPHERTAIL LOVEGRASS & POACEAE \\
\hline Eragrostis curvula & WEEPING LOVEGRASS & POACEAE \\
\hline Eragrostis elliottii & ELLIOTT LOVEGRASS & POACEAE \\
\hline Eragrostis glomerata & POND LOVEGRASS & POACEAE \\
\hline Eragrostis hypnoides & TEAL LOVEGRASS & POACEAE \\
\hline Eragrostis lugens & MOURNING LOVEGRASS & POACEAE \\
\hline Eragrostis pectinacea & SPREADING LOVEGRASS & POACEAE \\
\hline Eragrostis pilosa & INDIA LOVEGRASS & POACEAE \\
\hline Eragrostis refracta & COASTAL LOVEGRASS & POACEAE \\
\hline Eragrostis secundiflora & RED LOVEGRASS & POACEAE \\
\hline Eragrostis spectabilis & PURPLE LOVEGRASS & POACEAE \\
\hline Erechtites hieracifolia & FIREWEED & ASTERACEAE \\
\hline Eremochloa ophiuroides & CENTIPEDEGRASS & POACEAE \\
\hline Erianthus contortus & BENT-AWN PLUMEGRASS & POACEAE \\
\hline Erianthus giganteus & SUGARCANE PLUMEGRASS & POACEAE \\
\hline Erianthus strictus & NARROW PLUMEGRASS & POACEAE \\
\hline Erigeron annuus & DAISY FLEABANE & ASTERACEAE \\
\hline Erigeron philadelphicus & SHOWY DAISY FLEABANE & ASTERACEAE \\
\hline Erigeron pulchellus & POOR ROBIN'S PLANTAIN & ASTERACEAE \\
\hline Erigeron strigosus & WHITETOP FLEABANE & ASTERACEAE \\
\hline Erigeron tenuis & NODDING FLEABANE & ASTERACEAE \\
\hline Eriocaulon cinereum & PIPEWORT & ERIOCAULACEAE \\
\hline Eriocaulon compressum & FLATTENED PIPEWORT & ERIOCAULACEAE \\
\hline Eriocaulon decangulare & COMMON PIPEWORT & ERIOCAULACEAE \\
\hline Eriocaulon texense & TEXAS PIPEWORT & ERIOCAULACEAE \\
\hline Eriogonum longifolium & LONGLEAF BUCKWHEAT & POLYGONACEAE \\
\hline Eryngium integrifolium & BOG ERYNGO & APIACEAE \\
\hline Eryngium prostratum & BUTTON ERYNGO & APIACEAE \\
\hline Eryngium yuccifolium & BUTTON SNAKEROOT & APIACEAE \\
\hline Erythrina herbacea & MAMOU PLANT & FABACEAE \\
\hline
\end{tabular}


Table C1. Plant Species, with Common Name and Family, from the Limited Use Area, Vernon Ranger District, Kisatchie National Forest, Louisiana--Continued

\begin{tabular}{|c|c|}
\hline Plant Species & Common Name \\
\hline Euonymus americanus & WILD STRAWBERRY \\
\hline Eupatorium album & WHITE BONESET \\
\hline Eupatorium capillifolium & DOG FENNEL \\
\hline Eupatorium coelestinum & MIST FLOWER \\
\hline Eupatorium compositifolium & YANKEE WEED \\
\hline Eupatorium fistulosum & JOE-PYE WEED \\
\hline Eupatorium glaucescens & BONESET \\
\hline Eupatorium hyssopifolium & NARROWLEAF BONESET \\
\hline Eupatorium lancifolium & BONESET \\
\hline Eupatorium leucolepis & PALE BONESET \\
\hline Eupatorium perfoliatum & BONESET \\
\hline Eupatorium pinnatifidum & BONESET \\
\hline \multicolumn{2}{|l|}{ Eupatorium rotundifolium } \\
\hline var. ovatum & ROUND-LEAF BONESET \\
\hline \multicolumn{2}{|l|}{ Eupatorium rotundifolium } \\
\hline var. rotundifolium & ROUND-LEAF BONESET \\
\hline Eupatorium semiserratum & BONESET \\
\hline Eupatorium serotinum & FALL BONESET \\
\hline Euphorbia bicolor & SNOW-ON-THE-PRAIRIE \\
\hline Euphorbia corollata & FLOWERING SPURGE \\
\hline Euphorbia heterophylla & FIDDLER'S SPURGE \\
\hline Euphorbia marginata & SNOW-ON-THE-MOUNTAIN \\
\hline Euphorbia spathulata & SPURGE \\
\hline Euthamia gymnospermoides & FLAT-TOPPED GOLDENROD \\
\hline Euthamia leptocephala & FLAT-TOPPED GOLDENROD \\
\hline Facelis retusa & FACELIS \\
\hline Fagus grandifolia & AMERICAN BEECH \\
\hline Festuca arundinacea & REED FESCUE \\
\hline Ficus carica & FIG \\
\hline Fimbristylis autumnalis & SLENDER FIMBRY \\
\hline Fimbristylis castanea & LARGE MARSH FIMBRY \\
\hline Fimbristylis miliacea & GLOBE FIMBRY \\
\hline Fimbristylis tomentosa & HAIRY FIMBRY \\
\hline Fimbristylis vahlii & SANDBAR FIMBRY \\
\hline Fragaria virginiana & STRAWBERRY \\
\hline Fraxinus americana & WHITE ASH \\
\hline Fraxinus caroliniana & CAROLINA ASH \\
\hline Fraxinus pennsylvanica & GREEN ASH \\
\hline Froelichia floridana & COTTON WEED \\
\hline Froelichia gracilis & COTTON WEED \\
\hline
\end{tabular}

Eamily

CELASTRACEAE

ASTERACEAE

ASTERACEAE

ASTERACEAE

ASTERACEAE

ASTERACEAE

ASTERACEAE

ASTERACEAE

ASTERACEAE

ASTERACEAE

ASTERACEAE

ASTERACEAE

ASTERACEAE

ASTERACEAE

ASTERACEAE

ASTERACEAE

EUPHORBIACEAE

EUPHORBIACEAE

EUPHORBIACEAE

EUPHORBIACEAE

EUPHORBIACEAE

ASTERACEAE

ASTERACEAE

ASTERACEAE

FAGACEAE

POACEAE

MORACEAE

CYPERACEAE

CYPERACEAE

CYPERACEAE

CYPERACEAE

CYPERACEAE

ROSACEAE

OLEACEAE

OLEACEAE

OLEACEAE

AMARANTHACEAE

AMARANTHACEAE 
Table C1. Plant Species, with Common Name and Family, from the Limited Use Area, Vernon Ranger District, Kisatchie National Forest, Louisiana--Continued

\begin{tabular}{|c|c|c|}
\hline Plant Species & Common Name & Eamily \\
\hline Fuirena bushii & KRAL'S UMBRELLA SEDGE & CYPERACEAE \\
\hline Fuirena pumila & DWARF UMBRELLA SEDGE & CYPERACEAE \\
\hline Fuirena simplex & WESTERN UMBRELLA SEDGE & CYPERACEAE \\
\hline Fuirena squarrosa & HAIRY UMBRELLA SEDGE & CYPERACEAE \\
\hline \multicolumn{3}{|l|}{ Gaillardia aestivalis } \\
\hline var. aestivalis & INDIAN BLANKET & ASTERACEAE \\
\hline \multicolumn{3}{|l|}{ Gaillardia aestivalis } \\
\hline var. flavovirens & YELLOW INDIAN BLANKET & ASTERACEAE \\
\hline Gaillardia pulchella & INDIAN BLANKET & ASTERACEAE \\
\hline Galactia erecta & ERECT MILKPEA & FABACEAE \\
\hline Galactia regularis & EASTERN MILKPEA & FABACEAE \\
\hline Galactia volubilis & DOWNY MILKPEA & FABACEAE \\
\hline Galium aparine & CATCHWEED BEDSTRAW & RUBIACEAE \\
\hline Galium circaezans & LICORICE BEDSTRAW & RUBIACEAE \\
\hline Galium obtusum & BLUNTLEAF BEDSTRAW & RUBIACEAE \\
\hline Galium pilosum & HAIRY BEDSTRAW & RUBIACEAE \\
\hline Galium tinctorium & STIFF MARSH BEDSTRAW & RUBIACEAE \\
\hline Galium uniflorum & ONEFLOWER BEDSTRAW & RUBIACEAE \\
\hline Galium virgatum & SOUTHWESTERN BEDSTRAW & RUBIACEAE \\
\hline Gamochaeta pensylvanica & CUDWEED & ASTERACEAE \\
\hline Gamochaeta purpurea & PURPLE CUDWEED & ASTERACEAE \\
\hline Gaura lindheimeri & LINDHEIMER'S BEEBLOSSOM & ONAGRACEAE \\
\hline Gaura longiflora & LONGFLOWER BEEBLOSSOM & ONAGRACEAE \\
\hline Gelsemium sempervirens & YELLOW JASSMINE & LOGANIACEAE \\
\hline Gentiana saponaria & HARVESTBELLS & GENTIANACEAE \\
\hline Geranium carolinianum & WILD GERANIUM & GERANIACEAE \\
\hline Geranium dissectum & CUTLEAF GERANIUM & GERANIACEAE \\
\hline Geum canadense & WHITE AVENS & ROSACEAE \\
\hline Gillenia stipulacea & INDIAN PHYSIC & ROSACEAE \\
\hline Glandularia canadensis & DAKOTA MOCK VERVAIN & VERBENACEAE \\
\hline Glandularia pulchella & ROSE MOCK VERVAIN & VERBENACEAE \\
\hline Glandularia tenuisecta & SOUTH AMERICAN MOCK VERVAIN & VERBENACEAE \\
\hline Gleditsia aquatica & WATER LOCUST & FABACEAE \\
\hline Gleditsia triacanthos & HONEY LOCUST & FABACEAE \\
\hline Glottidium vesicarium & BAGPOD & FABACEAE \\
\hline Glyceria declinata & MANNAGRASS & POACEAE \\
\hline Gnaphalium helleri & RABBIT-TOBACCO & ASTERACEAE \\
\hline Gnaphalium obtusifolium & RABBIT-TOBACCO & ASTERACEAE \\
\hline Gratiola brevifolia & STICKY HEDGEHYSSOP & SCROPHULARIACEAE \\
\hline Gratiola neglecta & NEGLECTED HEDGEHYSSOP & SCROPHULARIACEAE \\
\hline
\end{tabular}


Table C1. Plant Species, with Common Name and Family, from the Limited Use Area, Vernon Ranger District, Kisatchie National Forest, Louisiana--Continued

\begin{tabular}{|c|c|c|}
\hline Plant Species & Common Name & Eamily \\
\hline Gratiola pilosa & SHAGGY HEDGEHYSSOP & SCROPHULARIACEAE \\
\hline Gratiola virginiana & ROUNDFRUIT HEDGEHYSSOP & SCROPHULARIACEAE \\
\hline Gymnopogon ambiguus & BEARDED SKELETONGRASS & POACEAE \\
\hline Gymnopogon brevifolius & SLIM SKELETONGRASS & POACEAE \\
\hline Habenaria repens & WATER SPIDER ORCHID & ORCHIDACEAE \\
\hline Halesia diptera & SILVERBELL & STYRACACEAE \\
\hline Hamamelis virginiana & WITCHHAZEL & HAMAMELIDACEAE \\
\hline Hedeoma hispida & ROUGH FALSEPENNYROYAL & LAMIACEAE \\
\hline Hedera helix & ENGLISH IVY & ARALIACEAE \\
\hline Hedyotis nigricans & DIAMONDFLOWERS & RUBIACEAE \\
\hline Helenium amarum & BITTERWEED & ASTERACEAE \\
\hline Helenium autumnale & TALL SNEEZEWEED & ASTERACEAE \\
\hline Helenium drummondii & SNEEZEWEED & ASTERACEAE \\
\hline Helenium flexuosum & SNEEZEWEED & ASTERACEAE \\
\hline Helenium vernale & VERNAL SNEEZEWEED & ASTERACEAE \\
\hline Helianthemum carolinianum & ROCKROSE & CISTACEAE \\
\hline Helianthemum georgianum & GEORGLA ROCKROSE & CISTACEAE \\
\hline Helianthus angustifolius & NARROW-LEAF SUNFLOWER & ASTERACEAE \\
\hline \multicolumn{3}{|l|}{ Helianthus debilis } \\
\hline ssp. cucumerifolius & WESTERN SUNFLOWER & ASTERACEAE \\
\hline Helianthus hirsutus & COMMON WILD SUNFLOWER & ASTERACEAE \\
\hline Heliopsis gracilis & SMOOTH OXEYE & ASTERACEAE \\
\hline Heliopsis helianthoides & SUNFLOWER EVERLASTING & ASTERACEAE \\
\hline Heliotropium indicum & TURNSOLE & BORAGINACEAE \\
\hline Heliotropium tenellum & NARROW-LEAF HELIOTROPE & BORAGINACEAE \\
\hline Herbertia lahue & PRAIRIENYMPH & IRIDACEAE \\
\hline Heterotheca subaxillaris & GOLDENASTER & ASTERACEAE \\
\hline \multicolumn{3}{|l|}{ Hibiscus moschuetos } \\
\hline ssp. lasiocarpus & CRIMSONEYED ROSEMALLOW & MALVACEAE \\
\hline \multicolumn{3}{|l|}{ Hibiscus moschuetos } \\
\hline ssp. moschuetos & CRIMSONEYED ROSEMALLOW & MALVACEAE \\
\hline Hieracium gronovii & HAWKWEED & ASTERACEAE \\
\hline Holcus lanatus & VELVETGRASS & POACEAE \\
\hline Hordeum pusillum & LTTLE BARLEY & POACEAE \\
\hline Houstonia micrantha & SOUTHERN BLUET & RUBLACEAE \\
\hline \multicolumn{3}{|l|}{ Houstonia purpurea } \\
\hline var. purpurea & VENUS'PRIDE & RUBIACEAE \\
\hline Houstonia pusilla & TINY BLUET & RUBIACEAE \\
\hline Houstonia rosea & ROSE BLUET & RUBIACEAE \\
\hline Hydrocotyle ranunculoides & FLOATING WATER PENNYWORT & APIACEAE \\
\hline Hydrocotyle umbellata & UMBRELLA WATER PENNYWORT & APIACEAE \\
\hline Hydrocotyle verticillata & COMMON WATER PENNYWORT & APIACEAE \\
\hline
\end{tabular}


Table C1. Plant Species, with Common Name and Family, from the Limited Use Area, Vernon Ranger District, Kisatchie National Forest, Louisiana--Continued

\begin{tabular}{|c|c|c|}
\hline Plant Species & Common Name & Eamily \\
\hline Hydrolea ovata & OVATE FALSE FIDDLELEAF & HYDROPHYLLACEAE \\
\hline Hydrolea uniflora & ONEFLOWER FALSE FIDDLELEAF & HYDROPHYLLACEAE \\
\hline Hymenocallis eulae & SPIDER LILY & LILIACEAE \\
\hline Hymenopappus artemisiifolius & WOOLLY WHITE & ASTERACEAE \\
\hline Hymenopappus scabiosaeus & WOOLLY WHITE & ASTERACEAE \\
\hline Hypericum crux-andreae & ST. ANDREW'S CROSS & CLUSIACEAE \\
\hline Hypericum densiflorum & SHRUBBY ST. JOHN'S WORT & CLUSIACEAE \\
\hline Hypericum drummondii & NITS AND LICE & CLUSIACEAE \\
\hline Hypericum fasciculatum & SANDBUSH ST. JOHN'S WORT & CLUSIACEAE \\
\hline Hypericum frondosum & SHOWY ST. JOHN'S WORT & CLUSIACEAE \\
\hline Hypericum galioides & BEDSTRAW ST. JOHN'S WORT & CLUSIACEAE \\
\hline Hypericum gentianoides & ORANGE-GRASS & CLUSIACEAE \\
\hline Hypericum gymnanthum & CLASPING ST. JOHN'S WORT & CLUSIACEAE \\
\hline \multicolumn{3}{|l|}{ Hypericum hypericoides } \\
\hline ssp. hypericoides & ST. ANDREW'S CROSS & CLUSIACEAE \\
\hline \multicolumn{3}{|l|}{ Hypericum hypericoides } \\
\hline ssp. multicaulis & DWARF ST. ANDREW'S CROSS & CLUSIACEAE \\
\hline Hypericum mutilum & LEAST ST. JOHN'S WORT & CLUSIACEAE \\
\hline Hypericum nudiflorum & DOGBANE ST. JOHN'S WORT & CLUSIACEAE \\
\hline Hypericum prolificum & BROOM BUSH & CLUSIACEAE \\
\hline Hypericum setosum & HAIRY ST. JOHN'S WORT & CLUSIACEAE \\
\hline Hypochoeris glabra & CAT'S EAR & ASTERACEAE \\
\hline Hypochoeris microcephala & CAT'S EAR & ASTERACEAE \\
\hline Hypochoeris radicata & CAT'S EAR & ASTERACEAE \\
\hline Hypoxis hirsuta & COMMON STAR-GRASS & LILIACEAE \\
\hline Hypoxis juncea & STAR-GRASS & LILIACEAE \\
\hline Hypoxis micrantha & BRISTLESEED STAR-GRASS & LILIACEAE \\
\hline Hypoxis rigida & STAR-GRASS & LILIACEAE \\
\hline Hypoxis sessilis & GLOSSSEED STAR-GRASS & LILIACEAE \\
\hline Hyptis alata & BUSHMINT & LAMIACEAE \\
\hline Ilex ambigua & CAROLINA HOLLY & AQUIFOLIACEAE \\
\hline Ilex coriacea & LARGE GALLBERRY & AQUIFOLIACEAE \\
\hline Ilex decidua & DECIDUOUS HOLLY & AQUIFOLIACEAE \\
\hline Mex longipes & GEORGIA HOLLY & AQUIFOLIACEAE \\
\hline Ilex opaca & AMERICAN HOLLY & AQUIFOLIACEAE \\
\hline Ilex vomitoria & YAUPON & AQUIFOLIACEAE \\
\hline \multicolumn{3}{|l|}{ Indigofera miniata } \\
\hline var. leptosephala & SCARLET PEA & FABACEAE \\
\hline Ionactis linariifolius & NARROWLEAF ASTER & ASTERACEAE \\
\hline Ipomoea cordatotriloba & COTTON MORNING GLORY & CONVOLVULACEAE \\
\hline
\end{tabular}


Table C1. Plant Species, with Common Name and Family, from the Limited Use Area, Vernon Ranger District, Kisatchie National Forest, Louisiana--Continued

\begin{tabular}{|c|c|c|}
\hline Plant Species & Common Name & Eamily \\
\hline Ipomoea lacunosa & SMALL WHITE MORNING GLORY & CONVOLVULACEAE \\
\hline Ipomoea nil & IVY-LEAF MORNING GLORY & CONVOLVULACEAE \\
\hline Ipomoea pandurata & WILD POTATO VINE & CONVOLVULACEAE \\
\hline Iris virginica & SOUTHERN BLUE-FLAG & IRIDACEAE \\
\hline Isoetes melanopoda & BLACK-FOOTED QUILLWORT & ISOETACEAE \\
\hline Isotria verticillata & WHORLED POGONIA & ORCHIDACEAE \\
\hline Itea virginica & VIRGINIA WILLOW & GROSSULARIACEAE \\
\hline Iva annua & SUMPWEED & ASTERACEAE \\
\hline Jacquemontia tamnifolia & TIE VINE & CONVOLVULACEAE \\
\hline Juglans nigra & BLACK WALNUT & JUGLANDACEAE \\
\hline Juncus acuminatus & KNOTLEAF RUSH & JUNCACEAE \\
\hline Juncus biflorus & TWOFLOWER RUSH & JUNCACEAE \\
\hline Juncus brachycarpus & WHITEROOT RUSH & JUNCACEAE \\
\hline Juncus bufonius & TOAD RUSH & JUNCACEAE \\
\hline Juncus capitatus & ANNUAL RUSH & JUNCACEAE \\
\hline Juncus coriaceus & LEATHERY RUSH & JUNCACEAE \\
\hline Juncus dichotomus & FORKED RUSH & JUNCACEAE \\
\hline Juncus diffusissimus & SLIMPOD RUSH & JUNCACEAE \\
\hline Juncus effusus & COMMON RUSH & JUNCACEAE \\
\hline Juncus elliottii & BOG RUSH & JUNCACEAE \\
\hline Juncus marginatus & GRASSLEAF RUSH & JUNCACEAE \\
\hline Juncus nodatus & JOINTED RUSH & JUNCACEAE \\
\hline Juncus polycephalus & FLATLEAF RUSH & JUNCACEAE \\
\hline Juncus repens & CREEPING RUSH & JUNCACEAE \\
\hline Juncus scirpoides & NEEDLEPOD RUSH & JUNCACEAE \\
\hline Juncus tenuis & POVERTY RUSH & JUNCACEAE \\
\hline Juncus trigonocarpus & RUSH & JUNCACEAE \\
\hline Juncus validus & ROUNDHEAD RUSH & JUNCACEAE \\
\hline Juniperus virginiana & EASTERN RED CEDAR & CUPRESSACEAE \\
\hline Justicia ovata & LANCE-LEAVED WATERWILLOW & ACANTHACEAE \\
\hline Koeleria gerardii & ANNUAL KOELERIA & POACEAE \\
\hline Krigia cespitosa & DWARF DANDELION & ASTERACEAE \\
\hline Krigia dandelion & POTATO DWARF DANDELION & ASTERACEAE \\
\hline Krigia virginica & DWARF DANDELION & ASTERACEAE \\
\hline Lachnocaulon anceps & WHITEHEAD BOGBUTTON & ERIOCAULACEAE \\
\hline Lachnocaulon digynum & BOGBUTTON & ERIOCAULACEAE \\
\hline Lactuca canadensis & WILD LETTUCE & ASTERACEAE \\
\hline Lactuca floridana & BLUE-FLOWERED LETTUCE & ASTERACEAE \\
\hline Lactuca ludoviciana & WILD LETTUCE & ASTERACEAE \\
\hline Lactuca serriola & PRICKLY LETTUCE & ASTERACEAE \\
\hline
\end{tabular}


Table C1. Plant Species, with Common Name and Family, from the Limited Use Area, Vernon Ranger District, Kisatchie National Forest, Louisiana--Continued

\begin{tabular}{|c|c|c|}
\hline Plant Species & Common Name & Eamily \\
\hline Lagenaria siceraria & SPONGE GOURD & CUCURBITACEAE \\
\hline Lagerstroemia indica & CREPE MYRTLE & LYTHRACEAE \\
\hline Lamium amplexicaule & HENBIT & LAMIACEAE \\
\hline Lantana camara & LANTANA & VERBENACEAE \\
\hline Lathyrus hirsutus & SINGLETARY PEAVINE & FABACEAE \\
\hline Lathyrus pusillus & TINY PEAVINE & FABACEAE \\
\hline Lechea mucronata & LARGE PINWEED & CISTACEAE \\
\hline Lechea tenuifolia & PINWEED & CISTACEAE \\
\hline Leersia oryzoides & RICE CUTGRASS & POACEAE \\
\hline Leersia virginica & WHITEGRASS & POACEAE \\
\hline Lemna aequinoctialis & DUCKWEED & LEMNACEAE \\
\hline Lemna minor & COMMON DUCKWEED & LEMNACEAE \\
\hline Lemna obscura & DUCKWEED & LEMNACEAE \\
\hline Lepidium virginicum & VIRGINIA PEPPERWEED & BRASSICACEAE \\
\hline Leptochloa fascicularis & BEARDED SPRANGLETOP & POACEAE \\
\hline Leptochloa scabra & ROUGH SPRANGLETOP & POACEAE \\
\hline Leptoloma cognatum & FALL WITCHGRASS & POACEAE \\
\hline Lepurapetalon spathulatum & PETTTEPLANT & SAXIFRAGACEAE \\
\hline Lespedeza capitata & ROUNDHEAD LESPEDEZA & FABACEAE \\
\hline Lespedeza cuneata & CHINESE LESPEDEZA & FABACEAE \\
\hline Lespedeza hirta & HAIRY LESPEDEZA & FABACEAE \\
\hline Lespedeza procumbens & TRAILING LESPEDEZA & FABACEAE \\
\hline Lespedeza repens & CREEPING LESPEDEZA & FABACEAE \\
\hline Lespedeza striata & JAPANESE CLOVER & FABACEAE \\
\hline Lespedeza stuevei & TALL LESPEDEZA & FABACEAE \\
\hline Lespedeza virginica & SLENDER LESPEDEZA & FABACEAE \\
\hline Leucospora multifida & NARROWLEAF PALESEED & SCROPHULARIACEAE \\
\hline Liatris acidota & SHARP BLAZING STAR & ASTERACEAE \\
\hline Liatris aspera & TALL BLAZING STAR & ASTERACEAE \\
\hline Liatris elegans & PINKSCALE BLAZING STAR & ASTERACEAE \\
\hline Liatris pycnostachya & KANSAS BLAZING STAR & ASTERACEAE \\
\hline Liatris spicata & BLAZING STAR & ASTERACEAE \\
\hline \multicolumn{3}{|l|}{ Liatris squarrosa } \\
\hline var. squarrosa & BUTTON BLAZING STAR & ASTERACEAE \\
\hline Liatris squarrulosa & BLAZING STAR & ASTERACEAE \\
\hline Ligustrum lucidum & GLOSSY PRTVET & OLEACEAE \\
\hline Ligustrum sinense & CHINESE PRIVET & OLEACEAE \\
\hline Lilium michauxii & CAROLINA LILY & LILIACEAE \\
\hline Limnodea arkansana & OZARKGRASS & POACEAE \\
\hline Limnosciadium pumilum & RICE-FIELD DOGSHADE & APIACEAE \\
\hline Lindera benzoin & SPICEBUSH & LAURACEAE \\
\hline
\end{tabular}


Table C1. Plant Species, with Common Name and Family, from the Limited Use Area, Vernon Ranger District, Kisatchie National Forest, Louisiana--Continued

\begin{tabular}{|c|c|c|}
\hline Plant Species & Common Name & Eamily \\
\hline Lindernia anagallidea & MOISTBANK PIMPERNEL & SCROPHULARIACEAE \\
\hline Lindernia dubia & FALSE PIMPERNEL & SCROPHULARIACEAE \\
\hline Linum floridanum var. floridanum & FLORIDA YELLOW FLAX & LINACEAE \\
\hline Linum medium & STIFF YELLOW FLAX & LINACEAE \\
\hline Linum striatum & RIDGED YELLOW FLAX & LINACEAE \\
\hline Liquidambar styraciflua & SWEET GUM & HAMAMELIDACEAE \\
\hline Liriodendron tulipifera & YELLOW POPLAR & MAGNOLIACEAE \\
\hline Listera australis & SOUTHERN TWAYBLADE & ORCHIDACEAE \\
\hline Lithospermum caroliniense & YELLOW STONESEED & BORAGINACEAE \\
\hline Lithospermum tuberosum & TUBEROUS STONESEED & BORAGINACEAE \\
\hline Lobelia appendiculata & PALE LOBELIA & CAMPANULACEAE \\
\hline Lobelia cardinalis & CARDINAL FLOWER & CAMPANULACEAE \\
\hline Lobelia flaccidifolia & LOBELIA & CAMPANULACEAE \\
\hline Lobelia puberula & PURPLE DEW DROP & CAMPANULACEAE \\
\hline Lobelia reverchonii & BAY-GALL LOBELIA & CAMPANULACEAE \\
\hline Lolium perenne & PERENNIAL RYEGRASS & POACEAE \\
\hline Lonicera japonica & JAPANESE HONEYSUCKLE & CAPRIFOLIACEAE \\
\hline Lonicera sempervirens & CORAL HONEYSUCKLE & CAPRIFOLIACEAE \\
\hline Ludwigia alternifolia & SEEDBOX & ONAGRACEAE \\
\hline Ludwigia decurrens & WINGLEAF PRIMROSEWILLOW & ONAGRACEAE \\
\hline \multirow[t]{2}{*}{ Ludwigia glandulosa } & CYLINDRICFRUIT & \\
\hline & PRIMROSEWILLOW & ONAGRACEAE \\
\hline Ludwigia hirtella & SPINDLEROOT & ONAGRACEAE \\
\hline Ludwigia leptocarpa & ANGLESTEM PRIMROSEWILLOW & ONAGRACEAE \\
\hline Ludwigia linearis & NARROWLEAF PRIMROSEWILLOW & ONAGRACEAE \\
\hline Ludwigia palustris & MARSH PURSLANE & ONAGRACEAE \\
\hline \multicolumn{3}{|l|}{ Ludwigia peploides } \\
\hline ssp. peploides & FLOATING PRIMROSEWILLOW & ONAGRACEAE \\
\hline Ludwigia pilosa & HAIRY PRIMROSEWILLOW & ONAGRACEAE \\
\hline Ludwigia uruguayensis & URUGUAYAN PRIMROSEWILLOW & ONAGRACEAE \\
\hline Lupinus texensis & TEXAS LUPINE & FABACEAE \\
\hline Luzula bulbosa & LAWN WOODRUSH & JUNCACEAE \\
\hline Luzula campestris & WOODRUSH & JUNCACEAE \\
\hline Luzula echinata & RAVINE WOODRUSH & JUNCACEAE \\
\hline Lycopodium appressum & SOUTHERN CLUB-MOSS & LYCOPODIACEAE \\
\hline Lycopodium alopecuroides & FOXTAIL CLUB-MOSS & LYCOPODIACEAE \\
\hline Lycopodium carolinianum & SLENDER CLUB-MOSS & LYCOPODIACEAE \\
\hline Lycopodium prostratum & FEATHER-STEM CLUB-MOSS & LYCOPODIACEAE \\
\hline Lycopus rubellus & TAPERLEAF WATERHOREHOUND & LAMIACEAE \\
\hline Lycopus virginicus & VIRGINIA WATERHOREHOUND & LAMIACEAE \\
\hline Lygodium japonicum & JAPANESE CLIMBING FERN & SCHIZAEACEAE \\
\hline
\end{tabular}


Table C1. Plant Species, with Common Name and Family, from the Limited Use Area, Vernon Ranger District, Kisatchie National Forest, Louisiana--Continued

\begin{tabular}{|c|c|c|}
\hline Plant Species & Common Name & Eamily \\
\hline Lyonia ligustrina & HE-HUCKLEBERRY & ERICACEAE \\
\hline Lyonia lucida & FETTERBUSH & ERICACEAE \\
\hline Lysimachia radicans & TRAILING YELLOW LOOSESTRIFE & PRIMULACEAE \\
\hline Lythrum alatum var. lanceolatum & WINGED LYTHRUM & LYTHRACEAE \\
\hline Lythurm lineare & WAND LYTHRUM & LYTHRACEAE \\
\hline Magnolia grandiflora & SOUTHERN MAGNOLIA & MAGNOLIACEAE \\
\hline Magnolia virginiana & WHITE BAY & MAGNOLIACEAE \\
\hline Malaxis unifolia & GREEN ADDER'S MOUTH & ORCHIDACEAE \\
\hline Malus angustifolia & CRABAPPLE & ROSACEAE \\
\hline Manfreda virginica & RATTLESNAKE MASTER & AGAVACEAE \\
\hline \multicolumn{3}{|l|}{ Marshallia caespitosa } \\
\hline var. caespitosa & BARBARA'S BUTTONS & ASTERACEAE \\
\hline \multicolumn{3}{|l|}{ Marshallia graminifolia } \\
\hline var. cynanthera & BARBARA'S BUTTONS & ASTERACEAE \\
\hline Marshallia trinervia & BARBARA'S BUTTONS & ASTERACEAE \\
\hline Matelea carolinensis & ANGLE POD & ASCLEPIADACEAE \\
\hline Matelea decipiens & ANGLE POD & ASCLEPIADACEAE \\
\hline Matelea gonocarpos & ANGLE POD & ASCLEPIADACEAE \\
\hline Mazus pumilus & JAPANESE MAZUS & SCROPHULARIACEAE \\
\hline Mecardonia acuminata & AXILFLOWER & SCROPHULARIACEAE \\
\hline Medicago lupulina & BLACK MEDIC CLOVER & FABACEAE \\
\hline Medicago polymorpha & BURCLOVER & FABACEAE \\
\hline Medicago sativa & ALFALFA & FABACEAE \\
\hline Melanthium virginicum & BUNCH FLOWER & LILIACEAE \\
\hline Melia azedarach & CHINABERRY & MELIACEAE \\
\hline Melica mutica & TWOFLOWER MELICGRASS & POACEAE \\
\hline Melilotus alba & WHITE SWEET CLOVER & FABACEAE \\
\hline Melilotus indica & YELLOW SWEET CLOVER & FABACEAE \\
\hline Melilotus officinalis & YELLOW SWEET CLOVER & FABACEAE \\
\hline Melochia corchorifolia & CHOCOLATEWEED & STERCULIACEAE \\
\hline Melothria pendula & MELONETTE & CUCURBITACEAE \\
\hline Micranthemum umbrosum & MUDWEED & SCROPHULARIACEAE \\
\hline Mikania cordifolia & HEMP VINE & ASTERACEAE \\
\hline Mikania scandens & HEMP VINE & ASTERACEAE \\
\hline \multicolumn{3}{|l|}{ Mimosa quadrivalvis } \\
\hline var. angustata & SENSITTVE BRIAR & FABACEAE \\
\hline \multicolumn{3}{|l|}{ Mimosa quadrivalvis } \\
\hline var. hystricina & CATCLAW SENSITIVE BRIAR & FABACEAE \\
\hline \multicolumn{3}{|l|}{ Mimosa quadrivalvis } \\
\hline var. nuttallii & SENSITIVE BRIAR & FABACEAE \\
\hline
\end{tabular}


Table C1. Plant Species, with Common Name and Family, from the Limited Use Area, Vernon Ranger District, Kisatchie National Forest, Louisiana--Continued

\begin{tabular}{|c|c|c|}
\hline Plant Species & Common Name & Eamily \\
\hline Mimosa strigillosa & POWDERPUFF & FABACEAE \\
\hline Mimulus alatus & MONKEY FLOWER & SCROPHULARIACEAE \\
\hline Miscanthus sinensis & EULALIA & POACEAE \\
\hline Mitchella repens & PARTRIDGE BERRY & RUBIACEAE \\
\hline Mitreola petiolata & LAX HORNPOD & LOGANIACEAE \\
\hline Mitreola sessilifolia & SWAMP HORNPOD & LOGANIACEAE \\
\hline Modiola caroliniana & CAROLINA BRISTLEMALLOW & MALVACEAE \\
\hline Mollugo verticillata & GREEN CARPETWEED & MOLLUGINACEAE \\
\hline Monarda fistulosa & WILDBERGAMOT BEEBALM & LAMIACEAE \\
\hline Monarda punctata & SPOTTED BEEBALM & LAMIACEAE \\
\hline Monotropa uniflora & INDIAN PIPES & MONOTROPACEAE \\
\hline Morus alba & WHITE MULBERRY & MORACEAE \\
\hline Morus rubra & RED MULBERRY & MORACEAE \\
\hline Muhlenbergia capillaris & HAIRAWN MUHLY & POACEAE \\
\hline Muhlenbergia schreberi & NIMBLEWILL & POACEAE \\
\hline Myosotis verna & GROMWELL & BORAGINACEAE \\
\hline Myosurus minimus & TINY MOUSETAIL & RANUNCULACEAE \\
\hline Myrica cerifera & WAXMYRTLE & MYRICACEAE \\
\hline Myrica heterophylla & BAYGALL WAXMYRTLE & MYRICACEAE \\
\hline Myriophyllum aquaticum & BRAZILIAN WATERMILFOIL & HALORAGACEAE \\
\hline Myriophyllum heterophyllum & TWOLEAF WATERMILFOIL & HALORAGACEAE \\
\hline Najas guadalupensis & COMMON WATERNYMPH & NAJADACEAEAE \\
\hline Narcissus jonquilla & JONQUIL & LILIACEAE \\
\hline Neptunia lutea & YELLOW PUFF & FABACEAE \\
\hline Nothoscordum bivalve & CROW POISON & LILIACEAE \\
\hline Nuphar lutea ssp. advena & YELLOW PONDLILY & NYMPHAEACEAE \\
\hline Nuttallanthus canadensis & CANADA TOADFLAX & SCROPHULARIACEAE \\
\hline Nuttallanthus texanus & TEXAS TOADFLAX & SCROPHULARIACEAE \\
\hline Nymphaea odorata & WHITE WATERLILY & NYMPHAEACEAE \\
\hline Nyssa aquatica & TUPELO GUM & NYSSACEAE \\
\hline Nyssa sylvatica var biflora & BLACK GUM & NYSSACEAE \\
\hline Nyssa sylvatica var sylvatica & SWAMP BLACK GUM & NYSSACEAE \\
\hline Oenothera biennis & COMMON EVENINGPRIMROSE & ONAGRACEAE \\
\hline Oenothera heterophylla & \multicolumn{2}{|c|}{ VARIABLELEAF EVENINGPRIMROSE ONAGRACEAE } \\
\hline Oenothera laciniata & CUTLEAF EVENINGPRIMROSE & ONAGRACEAE \\
\hline Oenothera linifolia & THREADLEAF EVENINGPRIMROSE & ONAGRACEAE \\
\hline Oenothera speciosa & PINKLADIES & ONAGRACEAE \\
\hline Oldenlandia boscii & BOSCS MILLE GRAINES & RUBIACEAE \\
\hline Oldenlandia uniflora & CLUSTERED MILLE GRAINES & RUBIACEAE \\
\hline Onoclea sensibilis & SENSITTVE FERN & WOODSIACEAE \\
\hline
\end{tabular}


Table C1. Plant Species, with Common Name and Family, from the Limited Use Area, Vernon Ranger District, Kisatchie National Forest, Louisiana--Continued

\begin{tabular}{|c|c|c|}
\hline Plant Species & Common Name & Eamily \\
\hline Onosmodium virginianum & FALSE GROMWELL & BORAGINACEAE \\
\hline Ophioglossum crotalophoroides & BULBOUS ADDER'S-TONGUE & OPHIOGLOSSACEAE \\
\hline Ophioglossum engelmannii & ENGLEMANN'S ADDER'S-TONGUE & OPHIOGLOSSACEAE \\
\hline Ophioglossum nudicaule & SLENDER ADDER'S-TONGUE & OPHIOGLOSSACEAE \\
\hline Oplismenus setarius & BASKETGRASS & POACEAE \\
\hline Opuntia humifusa var. humifusa & PRICKLY PEAR CACTUS & CACTACEAE \\
\hline Opuntia macrorhiza & PRICKLY PEAR CACTUS & CACTACEAE \\
\hline Orbexilium simplex & SAMPSON'S SNAKEROOT & FABACEAE \\
\hline Orbexilum pedunculatum & SINGLESTEM LEATHERROOT & FABACEAE \\
\hline Orobanche uniflora & BROOMRAPE & OROBANCHACEAE \\
\hline Oryza sativa & RICE & POACEAE \\
\hline Osmunda cinnamomea & CINNAMON FERN & OSMUNDACEAE \\
\hline Osmunda regalis var. spectabilis & ROYAL FERN & OSMUNDACEAE \\
\hline Ostrya virginiana & HOP HORNBEAM & BETULACEAE \\
\hline Oxalis corniculata & CREEPING WOODSORREL & OXALIDACEAE \\
\hline Oxalis corymbosa & PINK WOODSORREL & OXALIDACEAE \\
\hline Oxalis dillenii & DILLEN'S WOODSORREL & OXALIDACEAE \\
\hline Oxalis priceae & TUFortED YELLOW WOODSORREL & OXALIDACEAE \\
\hline Oxalis stricta & COMMON YELLOW OXALIS & OXALIDACEAE \\
\hline Oxalis violacea & VIOLET WOODSORREL & OXALIDACEAE \\
\hline Oxypolis filiformis & LEAFLESS COWBANE & APIACEAE \\
\hline Oxypolis rigidior & STIFF COWBANE & APIACEAE \\
\hline Panicum aciculare & PANIC GRASS & POACEAE \\
\hline \multicolumn{3}{|l|}{ Panicum acuminatum } \\
\hline var. acuminatum & PANIC GRASS & POACEAE \\
\hline \multicolumn{3}{|l|}{ Panicum acuminatum } \\
\hline var. leucothrix & PANIC GRASS & POACEAE \\
\hline \multicolumn{3}{|l|}{ Panicum acuminatum } \\
\hline var. lindheimeri & LINDHEIMER PANIC GRASS & POACEAE \\
\hline \multicolumn{3}{|l|}{ Panicum acuminatum } \\
\hline var. longiligulatum & PANIC GRASS & POACEAE \\
\hline Panicum anceps & BEAKED PANICUM & POACEAE \\
\hline Panicum angustifolium & PANIC GRASS & POACEAE \\
\hline Panicum boscii & PANIC GRASS & POACEAE \\
\hline Panicum brachyanthum & PIMPLE PANIC GRASS & POACEAE \\
\hline Panicum commutatum & VARIABLE PANIC GRASS & POACEAE \\
\hline Panicum consanguineum & PANIC GRASS & POACEAE \\
\hline Panicum depauperatum & STARVED PANIC GRASS & POACEAE \\
\hline Panicum dichotomiflorum & FALL PANICUM & POACEAE \\
\hline
\end{tabular}


Table C1. Plant Species, with Common Name and Family, from the Limited Use Area, Vernon Ranger District, Kisatchie National Forest, Louisiana--Continued

Plant Species

Panicum dichotomum var. dichotomum

Panicum dichotomum var. lucidum

Panicum dichotomum var. nitidum

Panicum dichotomum var. ramulosum

Panicum ensifolium var. curtifolium

Panicum flexile

Panicum gymnocarpon

Panicum hemitomon

Panicum hians

Panicum laxiflorum

Panicum oligosanthes var. oligosanthes

Panicum oligosanthes var. scribnerianum

Panicum ovale

Panicum polyanthes

Panicum ramosum

Panicum ravenelii

Panicum rigidulum var. pubescens

Panicum rigidulum var. rigidulum

Panicum scabriusculum

Panicum scoparium

Panicum sphaerocarpon

Panicum strigosum var. glabrescens

Panicum strigosum var. strigosum

Panicum tenerum

Panicum tenue

Panicum texanum

Panicum verrucosum

Panicum virgatum

Parthenocissus quinquefolia
Common Name

PANIC GRASS

POACEAE

PANIC GRASS

POACEAE

PANIC GRASS

POACEAE

PANIC GRASS

POACEAE

PANIC GRASS

POACEAE

WIRY WITCHGRASS

POACEAE

SAVANNAH PANICUM

POACEAE

MAIDENCANE

GAPING PANICUM

OPEN-FLOWER PANIC GRASS

POACEAE

POACEAE

POACEAE

SCRIBNER'S PANIC GRASS

POACEAE

PANIC GRASS

POACEAE

PANIC GRASS

LEAFY PANIC GRASS

POACEAE

POACEAE

BROWNTOP MILLET

PANIC GRASS

POACEAE

POACEAE

REDTOP PANICUM

POACEAE

REDTOP PANICUM

POACEAE

PANIC GRASS

VELVET PANIC GRASS

POACEAE

POACEAE

ROUND-SEED PANIC GRASS

PANIC GRASS

POACEAE

PANIC GRASS

POACEAE

BLUEJOINT PANICUM

POACEAE

PANIC GRASS

POACEAE

TEXAS MILLET

POACEAE

WARTY PANICUM

POACEAE

SWITCHGRASS

POACEAE

VIRGINIA CREEPER
VITACEAE 
Table C1. Plant Species, with Common Name and Family, from the Limited Use Area, Vernon Ranger District, Kisatchie National Forest, Louisiana--Continued

\begin{tabular}{|c|c|c|}
\hline Plant Species & Common Name & Eamily \\
\hline Paspalum bifidum & PITCHFORK PASPALUM & POACEAE \\
\hline Paspalum dilatatum & DALLISGRASS & POACEAE \\
\hline Paspalum floridanum & FLORIDA PASPALUM & POACEAE \\
\hline Paspalum laeve & FIELD PASPALUM & POACEAE \\
\hline Paspalum notatum var. saurae & PENSACOLA BAHIAGRASS & POACEAE \\
\hline Paspalum plicatulum & BROWNSEED PASPALUM & POACEAE \\
\hline Paspalum praecox & EARLY PASPALUM & POACEAE \\
\hline Paspalum pubiflorum & HAIRYSEED PASPALUM & POACEAE \\
\hline \multicolumn{3}{|l|}{ Paspalum setaceum } \\
\hline var. ciliatifolium & FRINGELEAF PASPALUM & POACEAE \\
\hline \multicolumn{3}{|l|}{ Paspalum setaceum } \\
\hline var. muhlenbergii & HURRAHGRASS & POACEAE \\
\hline \multicolumn{3}{|l|}{ Paspalum setaceum } \\
\hline var. setaceum & THIN PASPALUM & POACEAE \\
\hline \multicolumn{3}{|l|}{ Paspalum setaceum } \\
\hline var. stramineum & PASPALUM & POACEAE \\
\hline \multicolumn{3}{|l|}{ Paspalum setaceum } \\
\hline var. supinum & PASPALUM & POACEAE \\
\hline Paspalum urvillei & VASEYGRASS & POACEAE \\
\hline Passiflora incarnata & MAYPOP & PASSIFLORACEAE \\
\hline Passiflora lutea & YELLOW MAYPOP & PASSIFLORACEAE \\
\hline Pedicularis canadensis & LOUSEWORT & SCROPHULARIACEAE \\
\hline Peltandra virginica & ARROW ARUM & ARACEAE \\
\hline Penstemon digitalis & TALUS SLOPE PENSTEMON & SCROPHULARIACEAE \\
\hline Penstemon laxiflorus & EUSTIS LAKE BEARDTONGUE & SCROPHULARIACEAE \\
\hline Penstemon tubaeflorus & WHITE WAND BEARDTONGUE & SCROPHULARIACEAE \\
\hline Penthorum sedoides & DITCH STONECROP & CRASSULACEAE \\
\hline Perilla frutescens & BEEFSTEAKPLANT & LAMIACEAE \\
\hline Persea palustris & RED BAY & LAURACEAE \\
\hline Phalaris angusta & TIMOTHY CANARYGRASS & POACEAE \\
\hline Phalaris caroliniana & CAROLINA CANARYGRASS & POACEAE \\
\hline Phlox divaricata & WILD BLUE PHLOX & POLEMONIACEAE \\
\hline Phlox drummondii & ANNUAL PHLOX & POLEMONIACEAE \\
\hline Phlox pilosa & DOWNY PHLOX & POLEMONIACEAE \\
\hline Phoradendron tomentosum & MISTLETOE & VISCACEAE \\
\hline Phryma leptostachya & LOPSEED & VERBENACEAE \\
\hline Phyla cuneifolia & WEDGELEAF FOGFRUIT & VERBENACEAE \\
\hline Phyla lanceolata & NORTHERN FOGFRUIT & VERBENACEAE \\
\hline Phyla nodiflora & TURKEY TANGLE FOGFRUTT & VERBENACEAE \\
\hline Phyla $\mathrm{x}$ intermedia & FOGFRUTT & VERBENACEAE \\
\hline
\end{tabular}


Table C1. Plant Species, with Common Name and Family, from the Limited Use Area, Vernon Ranger District, Kisatchie National Forest, Louisiana--Continued

Plant Species

Phyllanthus caroliniensis

Physalis angulata

Physalis hederifolia

Physalis heterophylla

Physalis pumila

Physalis virginiana

Physostegia digitalis

Physostegia virginiana

Phytolacca americana

Pilea pumila

Pinguicula pumila

Pinus echinata

Pinus elliottii

Pinus glabra

Pinus palustris

Pinus taeda

Planera aquatica

Plantago aristata

Plantago heterophylla

Plantago lanceolata

Plantago virginica

Plantago wrightiana

Platanthera blephariglottis

Platanthera ciliaris

Platanthera clavellata

Platanthera cristata

Platanthera flava

Platanthera integra

Platanthera nivea

Platanus occidentalis

Pluchea camphorata

Pluchea foetida

Pluchea rosea

Poa annua

Poa autumnalis

Poa chapmaniana

Podophyllum peltatum

Pogonia ophioglossoides

Polygala cruciata

Polygala cymosa
Common Name

LEAF-SEED

CUTLEAF GROUNDCHERRY

IVYLEAF GROUNDCHERRY

CLAMMYLEAF GROUNDCHERRY

DWARF GROUNDCHERRY

VIRGINIA GROUNDCHERRY

FINGER FALSE DRAGONHEAD

FINGER FALSE DRAGONHEAD

POKE WEED

CLEAR WEED

SMALL BUTTERWORT

SHORTLEAF PINE

SLASH PINE

SPRUCE PINE

LONGLEAF PINE

LOBLOLLY PINE

WATER ELM

LARGEBRACTED PLANTAIN

SLENDER PLANTAIN

BUCKTHORN PLANTAIN

VIRGINIA PLANTAIN

WRIGHT'S PLANTAIN

WHITE FRINGED ORCHID

YELLOW FRINGED ORCHID

GREEN REIN ORCHID

CRESTED FRINGED ORCHID

SOUTHERN REIN ORCHID

YELLOW FRINGELESS ORCHID

SNOWY ORCHID

SYCAMORE

CAMPHORWEED

MARSH FLEABANE

MARSH FLEABANE

ANNUAL BLUEGRASS

AUTUMN BLUEGRASS

CHAPMAN BLUEGRASS

MAYAPPLE

ROSE POGONIA

DRUMHEADS

TALL PINEBARREN MILKWORT
Eamily

EUPHORBIACEAE

SOLANACEAE

SOLANACEAE

SOLANACEAE

SOLANACEAE

SOLANACEAE

LAMIACEAE

LAMIACEAE

PHYTOLACCACEAE

URTICACEAE

LENTIBULARIACEAE

PINACEAE

PINACEAE

PINACEAE

PINACEAE

PINACEAE

ULMACEAE

PLANTAGINACEAE

PLANTAGINACEAE

PLANTAGINACEAE

PLANTAGINACEAE

PLANTAGINACEAE

ORCHIDACEAE

ORCHIDACEAE

ORCHIDACEAE

ORCHIDACEAE

ORCHIDACEAE

ORCHIDACEAE

ORCHIDACEAE

PLATANACEAE

ASTERACEAE

ASTERACEAE

ASTERACEAE

POACEAE

POACEAE

POACEAE

BERBERIDACEAE

ORCHIDACEAE

POLYGALACEAE

POLYGALACEAE 
Table C1. Plant Species, with Common Name and Family, from the Limited Use Area, Vernon Ranger District, Kisatchie National Forest, Louisiana--Continued

\begin{tabular}{|c|c|c|}
\hline Plant Species & Common Name & Eamily \\
\hline Polygala incarnata & PROCESSION FLOWER & POLYGALACEAE \\
\hline Polygala leptocaulis & SWAMP MILKWORT & POLYGALACEAE \\
\hline Polygala mariana & MARYLAND MILKWORT & POLYGALACEAE \\
\hline Polygala nana & CANDYROOT & POLYGALACEAE \\
\hline Polygala polygama & RACEMED MILKWORT & POLYGALACEAE \\
\hline Polygala ramosa & LOW PINEBARREN MILKWORT & POLYGALACEAE \\
\hline Polygala verticillata & WHORLED MILKWORT & POLYGALACEAE \\
\hline Polygonatum biflorum & SOLOMON'S SEAL & LILIACEAE \\
\hline Polygonum densiflorum & DENSEFLOWER KNOTWEED & POLYGONACEAE \\
\hline Polygonum hydropiperoides & SWAMP KNOTWEED & POLYGONACEAE \\
\hline Polygonum lapathifolium & SMARTWEED & POLYGONACEAE \\
\hline Polygonum pensylvanicum & PENNSYLVANIA SMARTWEED & POLYGONACEAE \\
\hline Polygonum persicaria & SPOTTED LADYSTHUMB & POLYGONACEAE \\
\hline Polygonum punctatum & DOTTED KNOTWEED & POLYGONACEAE \\
\hline Polygonum setaceum & BOG SMARTWEED & POLYGONACEAE \\
\hline Polygonum virginianum & JUMPSEED & POLYGONACEAE \\
\hline Polypodium polypodioides & RESURRECTION FERN & POLYPODIACEAE \\
\hline Polypogon monspeliensis & RABBITFOOT GRASS & POACEAE \\
\hline Polypremum procumbens & JUNIPER-WEED & BUDDLEJACEAE \\
\hline Polystichum acrostichoides & CHRISTMAS FERN & DRYOPTERIDACEAE \\
\hline Poncirus trifoliata & TRIFOLIATE ORANGE & RUTACEAE \\
\hline Populus deltoides & COTTONWOOD & SALICACEAE \\
\hline Portulaca oleracea & PURSLANE & PORTULACEAE \\
\hline Portulaca pilosa & KISS ME QUICK & PORTULACEAE \\
\hline Potamogeton diversifolius & COMMON PONDWEED & POTAMOGETONACEAE \\
\hline Potamogeton nodosus & AMERICAN PONDWEED & POTAMOGETONACEAE \\
\hline Potamogeton pulcher & HEARTLEAF PONDWEED & POTAMOGETONACEAE \\
\hline Prenanthes barbata & RATTLESNAKE ROOT & ASTERACEAE \\
\hline Proserpinaca palustris & MARSH MERMAIDWEED & HALORAGACEAE \\
\hline Proserpinaca pectinata & COMBLEAF MERMAIDWEED & HALORAGACEAE \\
\hline Prunella vulgaris & HEAL ALL & LAMIACEAE \\
\hline Prunus americana & AMERICAN PLUM & ROSASCEAE \\
\hline Prunus angustifolia & CHICKASAW PLUM & ROSASCEAE \\
\hline Prunus caroliniana & CAROLINA LAUREL CHERRY & ROSASCEAE \\
\hline Prunus mexicana & MEXICAN PLUM & ROSASCEAE \\
\hline Prunus persica & PEACH & ROSASCEAE \\
\hline Prunus serotina & BLACK CHERRY & ROSASCEAE \\
\hline Prunus umbellata & HOG PLUM & ROSASCEAE \\
\hline Psilocarya nitens & SHORTBEAK BALDSEDGE & CYPERACEAE \\
\hline Ptelea trifoliata & HOP WAFER TREE & RUTACEAE \\
\hline
\end{tabular}


Table C1. Plant Species, with Common Name and Family, from the Limited Use Area, Vernon Ranger District, Kisatchie National Forest, Louisiana--Continued

\begin{tabular}{|c|c|c|}
\hline Plant Species & Common Name & Eamily \\
\hline Pteridium aquilinum & BRACKEN FERN & DENNSTAEDTIACEAE \\
\hline Pteroglossaspis ecristata & WILD COCO & ORCHIDACEAE \\
\hline Ptilimnium capillaceum & \multicolumn{2}{|c|}{ THREADLEAF MOCK BISHOP'S WEED APIACEAE } \\
\hline Ptilimnium costatum & MOCK BISHOP'S WEED & APIACEAE \\
\hline Ptilimnium nuttallii & NUTTALL'S MOCK BISHOP'S WEED & APIACEAE \\
\hline Ptilimnium $x$ texense & TEXAS MOCK BISHOP'S WEED & APIACEAE \\
\hline Pueraria montana var. lobata & KUDZU & FABACEAE \\
\hline Pycnanthemum albescens & MOUNTAIN MINT & LAMIACEAE \\
\hline Pycnanthemum tenuifolium & NARROWLEAF MOUNTAIN MINT & LAMIACEAE \\
\hline Pyracantha coccinea & SCARLET FIRETHORN & ROSACEAE \\
\hline Pyrrhopappus carolinianus & FALSE DANDELION & ASTERACEAE \\
\hline Pyrus communis & PEAR & ROSACEAE \\
\hline Quercus alba & WHITE OAK & FAGACEAE \\
\hline Quercus falcata var falcata & SOUTHERN RED OAK & FAGACEAE \\
\hline Quercus hemisphaerica & DARLINGTON'S OAK & FAGACEAE \\
\hline Quercus incana & SANDJACK OAK & FAGACEAE \\
\hline Quercus laurifolia & LAUREL OAK & FAGACEAE \\
\hline Quercus lyrata & OVERCUP OAK & FAGACEAE \\
\hline Quercus margarettiae & RUNNER OAK & FAGACEAE \\
\hline Quercus marilandica & BLACKJACK OAK & FAGACEAE \\
\hline Quercus michauxii & COW OAK & FAGACEAE \\
\hline Quercus muhlenbergii & CHINQUAPIN OAK & FAGACEAE \\
\hline Quercus nigra & WATER OAK & FAGACEAE \\
\hline Quercus pagoda & CHERRYBARK OAK & FAGACEAE \\
\hline Quercus phellos & WILLOW OAK & FAGACEAE \\
\hline Quercus shumardii & SHUMARD RED OAK & FAGACEAE \\
\hline Quercus similis & DELTA POST OAK & FAGACEAE \\
\hline Quercus stellata & POST OAK & FAGACEAE \\
\hline Quercus velutina & BLACK OAK & FAGACEAE \\
\hline Quercus virginiana & LIVE OAK & FAGACEAE \\
\hline Ranunculus abortivus & LITTLELEAF BUTTERCUP & RANUNCULACEAE \\
\hline Ranunculus fascicularis & EARLY BUTTERCUP & RANUNCULACEAE \\
\hline Ranunculus marginatus & MARGINED BUTTERCUP & RANUNCULACEAE \\
\hline Ranunculus muricatus & SPINYFRUIT BUTTERCUP & RANUNCULACEAE \\
\hline Ranunculus parviflorus & SMALLFLOWER BUTTERCUP & RANUNCULACEAE \\
\hline Ranunculus platensis & PRAIRIE BUTTERCUP & RANUNCULACEAE \\
\hline Ranunculus pusillus & LOW SPEARWORT & RANUNCULACEAE \\
\hline Ranunculus sardous & HAIRY BUTTERCUP & RANUNCULACEAE \\
\hline Ranunculus scleratus & CELERYLEAF BUTTERCUP & RANUNCULACEAE \\
\hline Ratibida pinnata & YELLOW CONEFLOWER & ASTERACEAE \\
\hline
\end{tabular}


Table C1. Plant Species, with Common Name and Family, from the Limited Use Area, Vernon Ranger District, Kisatchie National Forest, Louisiana--Continued

\begin{tabular}{|c|c|c|}
\hline Plant Species & Common Name & Eamily \\
\hline Rhamnus caroliniana & CAROLINA BUCKTHORN & RHAMNACEAE \\
\hline Rhexia alifanus & SAVANNAH MEADOWBEAUTY & MELASTOMATACEAE \\
\hline Rhexia lutea & YELLOW MEADOWBEAUTY & MELASTOMATACEAE \\
\hline Rhexia mariana & MARYLAND MEADOWBEAUTY & MELASTOMATACEAE \\
\hline Rhexia petiolata & FRINGED MEADOWBEAUTY & MELASTOMATACEAE \\
\hline Rhexia virginica & HANDSOME HARRY & MELASTOMATACEAE \\
\hline Rhododendron canescens & SWEET AZALEA & ERICACEAE \\
\hline Rhododendron coryi & WHITE AZALEA & ERICACEAE \\
\hline Rhododendron oblongifolium & WHITE AZALEA & ERICACEAE \\
\hline Rhododendron viscosum & LATE AZALEA & ERICACEAE \\
\hline Rhus aromatica & AROMATIC SUMAC & ANACARDIACEAE \\
\hline Rhus copallinum & WINGED SUMAC & ANACARDIACEAE \\
\hline Rhynchosia difformis & DOUBLEFORM SNOUTBEAN & FABACEAE \\
\hline Rhynchosia latifolia & PRAIRIE SNOUTBEAN & FABACEAE \\
\hline Rhynchosia reniformis & DOLLARLEAF & FABACEAE \\
\hline Rhynchosia tomentosa & TWINING SNOUTBEAN & FABACEAE \\
\hline Rhynchospora caduca & ANGLESTEM BEAKSEDGE & CYPERACEAE \\
\hline Rhynchospora capitellata & POINTBEAK BEAKSEDGE & CYPERACEAE \\
\hline Rhynchospora cephalantha & BEAKSEDGE & CYPERACEAE \\
\hline Rhynchospora chalarocephala & BEAKSEDGE & CYPERACEAE \\
\hline Rhynchospora corniculata & HORNED BEAKSEDGE & CYPERACEAE \\
\hline Rhynchospora debilis & BEAKSEDGE & CYPERACEAE \\
\hline Rhynchospora elliottii & ELLIOTT'S BEAKSEDGE & CYPERACEAE \\
\hline Rhynchospora fascicularis & STOUT BEAKSEDGE & CYPERACEAE \\
\hline Rhynchospora filifolia & BRISTLELEAF BEAKSEDGE & CYPERACEAE \\
\hline Rhynchospora globularis & GLOBE BEAKSEDGE & CYPERACEAE \\
\hline Rhynchospora glomerata & CLUSTER BEAKSEDGE & CYPERACEAE \\
\hline Rhynchospora gracilenta & SLENDER BEAKSEDGE & CYPERACEAE \\
\hline Rhynchospora grayi & GRAY'S BEAKSEDGE & CYPERACEAE \\
\hline Rhynchospora harveyi & HARVEY BEAKSEDGE & CYPERACEAE \\
\hline Rhynchospora inexpansa & NODDING BEAKSEDGE & CYPERACEAE \\
\hline Rhynchospora intermixta & BEAKSEDGE & CYPERACEAE \\
\hline Rhynchospora macra & LARGE BEAKSEDGE & CYPERACEAE \\
\hline Rhynchospora macrostachya & TALL BEAKSEDGE & CYPERACEAE \\
\hline Rhynchospora microcarpa & SMALLFRUIT BEAKSEDGE & CYPERACEAE \\
\hline Rhynchospora miliacea & BEAKSEDGE & CYPERACEAE \\
\hline Rhynchospora mixta & BEAKSEDGE & CYPERACEAE \\
\hline Rhynchospora oligantha & FEWFLOWER BEAKSEDGE & CYPERACEAE \\
\hline Rhynchospora perplexa & BEAKSEDGE & CYPERACEAE \\
\hline Rhynchospora plumosa & BEAKSEDGE & CYPERACEAE \\
\hline
\end{tabular}


Table C1. Plant Species, with Common Name and Family, from the Limited Use Area, Vernon Ranger District, Kisatchie National Forest, Louisiana--Continued

\begin{tabular}{|c|c|c|}
\hline Plant Species & Common Name & Eamily \\
\hline Rhynchospora pusilla & LITTLE BEAKSEDGE & CYPERACEAE \\
\hline Rhynchospora rariflora & THREAD BEAKSEDGE & CYPERACEAE \\
\hline Richardia scabra & ROUGH MEXICAN CLOVER & RUBIACEAE \\
\hline Robinia hispida & BRISTLY LOCUST & FABACEAE \\
\hline Robinia pseudoacacia & BLACK LOCUST & FABACEAE \\
\hline Rorippa sessiliflora & YELLOW CRESS & BRASSICACEAE \\
\hline Rosa bracteata & MACARTNEY ROSE & ROSACEAE \\
\hline Rosa laevigata & CHEROKEE ROSE & ROSACEAE \\
\hline Rotala ramosior & ROTALA & LYTHRACEAE \\
\hline Rubus aboriginum & GARDEN DEWBERRY & ROSACEAE \\
\hline Rubus argutus & SAWTOOTH BLACKBERRY & ROSACEAE \\
\hline Rubus flagellaris & NORTHERN DEWBERRY & ROSACEAE \\
\hline Rubus trivialis & SOUTHERN DEWBERRY & ROSACEAE \\
\hline Rudbeckia grandiflora & ROUGH CONEFLOWER & ASTERACEAE \\
\hline Rudbeckia hirta & BLACK-EYED SUSAN & ASTERACEAE \\
\hline Rudbeckia missouriensis & BROWN-EYED SUSAN & ASTERACEAE \\
\hline Rudbeckia nitida & TEXAS BROWN-EYED SUSAN & ASTERACEAE \\
\hline Rudbeckia scabrifolia & BOG BROWN-EYED SUSAN & ASTERACEAE \\
\hline Rudbeckia subtomentosa & SWEET CONEFLOWER & ASTERACEAE \\
\hline Ruellia caroliniensis & WILD PETUNIA & ACANTHACEAE \\
\hline Ruellia humilis & PRAIRIE PETUNIA & ACANTHACEAE \\
\hline Rumex crispus & CURLY DOCK & POLYGONACEAE \\
\hline Rumex hastatulus & HEARTWING SORREL & POLYGONACEAE \\
\hline Rumex pulcher & FIDDLE DOCK & POLYGONACEAE \\
\hline Sabal minor & PALMETTO & ARECACEAE \\
\hline Sabatia brachiata & NARROWLEAF ROSEGENTIAN & GENTIANACEAE \\
\hline Sabatia campestris & TEXAS STAR & GENTIANACEAE \\
\hline Sabatia gentianoides & PINEWOODS ROSEGENTIAN & GENTIANACEAE \\
\hline Sabatia macrophylla & LARGELEAF ROSEGENTIAN & GENTIANACEAE \\
\hline Sacciolepis indica & INDIAN CUPSCALE & POACEAE \\
\hline Sagina decumbens & BIRDSEYE PEARLWORT & CARYOPHYLLACEAE \\
\hline Sagittaria calycina & URUGUAY ARROWLEAF & ALISMATACEAE \\
\hline Sagittaria graminea & NARROW-LEAVED BULL-TONGUE & ALISMATACEAE \\
\hline Sagittaria latifolia & ARROWHEAD & ALISMATACEAE \\
\hline Sagittaria papillosa & ARROWHEAD & ALISMATACEAE \\
\hline Sagittaria platyphylla & DELTA DUCK POTATO & ALISMATACEAE \\
\hline Salix exigua & SANDBAR WILLOW & SALICACEAE \\
\hline Salix nigra & BLACK WILLOW & SALICACEAE \\
\hline Salvia azurea & BLUE SAGE & LAMIACEAE \\
\hline Salvia lyrata & LYRELEAF SAGE & LAMIACEAE \\
\hline
\end{tabular}


Table C1. Plant Species, with Common Name and Family, from the Limited Use Area, Vernon Ranger District, Kisatchie National Forest, Louisiana--Continued

\begin{tabular}{|c|c|c|}
\hline Plant Species & Common Name & Eamily \\
\hline Sambucus canadensis & ELDERBERRY & CAPRIFOLIACEAE \\
\hline \multicolumn{3}{|l|}{ Samolus valerandi } \\
\hline ssp. parviflorus & SEASIDE BROOKWEED & PRIMULACEAE \\
\hline Sanicula canadensis & SANICLE & APIACEAE \\
\hline Sapium sebiferum & CHINESE TALLOW TREE & EUPHORBIACEAE \\
\hline Sarracenia alata & PITCHER PLANT & SARRACENIACEAE \\
\hline Sassafras albidum & SASSAFRAS & LAURACEAE \\
\hline Saururus cernuus & LIZARD'S TAIL & SAURURACEAE \\
\hline Schizachyrium scoparium & LITTLE BLUESTEM & POACEAE \\
\hline Schizachyrium tenerum & SLENDER BLUESTEM & POACEAE \\
\hline Schoenolirion croceum & YELLOW SUNNYBELL & LILIACEAE \\
\hline Scirpus atrovirens & PALE BULRUSH & CYPERACEAE \\
\hline Scirpus cyperinus & WOOLY SEDGE & CYPERACEAE \\
\hline Scirpus koilolepis & SANDBAR BULRUSH & CYPERACEAE \\
\hline Scirpus lineatus & SWAMPWOODS BULRUSH & CYPERACEAE \\
\hline Scirpus molestus & BULRUSH & CYPERACEAE \\
\hline Scleria baldwinii & BALDWIN NUTSEDGE & CYPERACEAE \\
\hline Scleria ciliata & FRINGED NUTSEDGE & CYPERACEAE \\
\hline Scleria georgiana & GEORGIA NUTSEDGE & CYPERACEAE \\
\hline Scleria oligantha & LTTTLEHEAD NUTSEDGE & CYPERACEAE \\
\hline Scleria pauciflora & FEWFLOWER NUTSEDGE & CYPERACEAE \\
\hline Scleria reticularis & BOG NUTSEDGE & CYPERACEAE \\
\hline Scleria triglomerata & WHIP NUTSEDGE & CYPERACEAE \\
\hline Scoparia dulcis & LICORICE WEED & SCROPHULARIACEAE \\
\hline Scutellaria cardiophylla & GULF SKULLCAP & LAMIACEAE \\
\hline Scutellaria drummondii & DRUMMOND'S SKULLCAP & LAMIACEAE \\
\hline Scutellaria elliptica & HAIRY SKULLCAP & LAMIACEAE \\
\hline Scutellaria integrifolia & HELMET FLOWER & LAMIACEAE \\
\hline Scutellaria ovata & HEARTLEAF SKULLCAP & LAMIACEAE \\
\hline Scutellaria parvula & SMALL SKULLCAP & LAMIACEAE \\
\hline Sebastiana fruticosa & CANDLEBERRY & EUPHORBIACEAE \\
\hline Selaginella apoda & MEADOW SPIKE-MOSS & SELAGINELLACEAE \\
\hline Selaginella arenicola & SAND SPIKE-MOSS & SELAGINELLACEAE \\
\hline Senecio glabellus & YELLOWTOP & ASTERACEAE \\
\hline Senecio plattensis & PRAIRIE RAGWORT & ASTERACEAE \\
\hline Senecio tomentosus & WOOLY GOLDEN RAGWORT & ASTERACEAE \\
\hline Sesbania exaltata & HEMP SESBANIA & FABACEAE \\
\hline Sesbania punicea & RATTLEBOX & FABACEAE \\
\hline Setaria geniculata & KNOTROOT BRISTLEGRASS & POACEAE \\
\hline Setaria glauca & YELLOW BRISTLEGRASS & POACEAE \\
\hline
\end{tabular}


Table C1. Plant Species, with Common Name and Family, from the Limited Use Area, Vernon Ranger District, Kisatchie National Forest, Louisiana--Continued

\begin{tabular}{|c|c|c|}
\hline Plant Species & Common Name & Eamily \\
\hline Seymeria cassinoides & YAUPON BLACKSENNA & SCROPHULARIACEAE \\
\hline Sherardia arvensis & BLUE FIELDMADDER & RUBIACEAE \\
\hline Sida rhombifolia & CUBAN JUTE & MALVACEAE \\
\hline Sida spinosa & PRICKLY FANPETALS & MALVACEAE \\
\hline Silene antirrhina & SLEEPY CATCHFLY & CARYOPHYLLACEAE \\
\hline Silene gallica & ENGLISH CATCHFLY & CARYOPHYLLACEAE \\
\hline Silene stellata & STARRY CAMPION & CARYOPHYLLACEAE \\
\hline Silene subciliata & SCARLET CATCHFLY & CARYOPHYLLACEAE \\
\hline Silphium asteriscus & ROSINWEED & ASTERACEAE \\
\hline Silphium gracile & SLENDER ROSINWEED & ASTERACEAE \\
\hline Silphium integrifolium & WHOLELEAF ROSINWEED & ASTERACEAE \\
\hline Silphium laciniatum & COMPASS PLANT & ASTERACEAE \\
\hline Silphium radula & ROUGHSTEM ROSINWEED & ASTERACEAE \\
\hline Sisyrinchium albidum & WHITE BLUEEYED GRASS & IRIDACEAE \\
\hline Sisyrinchium angustifolium & NARROWLEAF BLUEEYED GRASS & IRIDACEAE \\
\hline Sisyrinchium atlanticum & EASTERN BLUEEYED GRASS & IRIDACEAE \\
\hline Sisyrinchium campestre & PRAIRIE BLUEEYED GRASS & IRIDACEAE \\
\hline Sisyrinchium exile & SMALL YELLOW BLUEEYED GRASS & IRIDACEAE \\
\hline Sisyrinchium langloisii & PALE BLUEEYED GRASS & IRIDACEAE \\
\hline Sisyrinchium mucronatum & BLUEEYED GRASS & IRIDACEAE \\
\hline Sisyrinchium rosulatum & SPREADING BLUEEYED GRASS & IRIDACEAE \\
\hline Sisyrinchium sagittiferum & \multicolumn{2}{|c|}{ SPEAR-BRACTED BLUEEYED GRASS IRIDACEAE } \\
\hline Smallanthus uvedalia & BEAR'S FOOT & ASTERACEAE \\
\hline Smilax bona-nox & FIDDLELEAF GREENBRIAR & SMILACACEAE \\
\hline Smilax glauca & SAWBRIAR & SMILACACEAE \\
\hline Smilax herbacea & CARRION FLOWER & SMILACACEAE \\
\hline Smilax hispida & HELLFETTER & SMILACACEAE \\
\hline Smilax laurifolia & LOWLAND BAMBOO VINE & SMILACACEAE \\
\hline Smilax pumila & SARSAPARILLA VINE & SMILACACEAE \\
\hline Smilax rotundifolia & COMMON GREENBRIAR & SMILACACEAE \\
\hline Smilax smallii & UPLAND BAMBOO VINE & SMILACACEAE \\
\hline Smilax walteri & RED BERRY GREENBRIAR & SMILACACEAE \\
\hline Solanum carolinense & HORSENETTLE & SOLANACEAE \\
\hline Solanum elaeagnifolium & SILVERLEAF NIGHTSHADE & SOLANACEAE \\
\hline Solanum ptycanthum & NIGHTSHADE & SOLANACEAE \\
\hline Solanum rostratum & BUFFALOBUR NIGHTSHADE & SOLANACEAE \\
\hline Solidago arguta var. boottii & BOOT'S CUT-LEAF GOLDENROD & ASTERACEAE \\
\hline Solidago auriculata & CLASPING GOLDENROD & ASTERACEAE \\
\hline Solidago caesia & BLUE GOLDENROD & ASTERACEAE \\
\hline Solidago canadensis & COMMON GOLDENROD & ASTERACEAE \\
\hline
\end{tabular}


Table C1. Plant Species, with Common Name and Family, from the Limited Use Area, Vernon Ranger District, Kisatchie National Forest, Louisiana--Continued

\begin{tabular}{|c|c|c|}
\hline Plant Species & Common Name & Eamily \\
\hline Solidago ludoviciana & GOLDENROD & ASTERACEAE \\
\hline Solidago nitida & FLAT-TOPPED GOLDENROD & ASTERACEAE \\
\hline Solidago odora & SWEET GOLDENROD & ASTERACEAE \\
\hline Solidago patula & ROUNDLEAF GOLDENROD & ASTERACEAE \\
\hline Solidago patula var. strictula & BAY-GALL GOLDENROD & ASTERACEAE \\
\hline Solidago petiolaris & NARROWLEAF GOLDENROD & ASTERACEAE \\
\hline Solidago radula & ROUGH GOLDENROD & ASTERACEAE \\
\hline Solidago rugosa ssp. aspera & ROUGH GOLDENROD & ASTERACEAE \\
\hline Solidago rugosa ssp. rugosa & ROUGH GOLDENROD & ASTERACEAE \\
\hline Solidago speciosa & NOBLE GOLDENROD & ASTERACEAE \\
\hline Solidago tortifolia & TWISTED-LEAF GOLDENROD & ASTERACEAE \\
\hline Solidago ulmifolia & ELM-LEAF GOLDENROD & ASTERACEAE \\
\hline Soliva sessilis & STICKERS & ASTERACEAE \\
\hline Sonchus asper & PRICKLY SOW-THISTLE & ASTERACEAE \\
\hline Sonchus oleraceus & SMOOTH SOW-THISTLE & ASTERACEAE \\
\hline Sorghastrum elliottii & SLENDER INDIANGRASS & POACEAE \\
\hline Sorghastrum nutans & INDIANGRASS & POACEAE \\
\hline Sorghum bicolor & BROOMCORN & POACEAE \\
\hline Sorghum halepense & JOHNSONGRASS & POACEAE \\
\hline Sparganium americanum & BUR-REED & SPARGANIACEAE \\
\hline Spermolepis divaricata & FORKED SCALESEED & APIACEAE \\
\hline Spermolepis echinata & BRISTLY SCALESEED & APIACEAE \\
\hline Spermolepis inermis & SPREADING SCALESEED & APIACEAE \\
\hline Sphenoclea zeylandica & SPHENOCLEA & SPHENOCLEACEAE \\
\hline Sphenopholis filiformis & LONGLEAF WEDGESCALE & POACEAE \\
\hline Sphenopholis longiflora & WEDGESCALE & POACEAE \\
\hline Sphenopholis nitida & SHINY WEDGESCALE & POACEAE \\
\hline Sphenopholis obtusata & PRAIRIE WEDGESCALE & POACEAE \\
\hline Spigelia marilandica & INDIAN PINK & LOGANIACEAE \\
\hline Spiranthes cernua & NODDING LADIES' TRESSES & ORCHIDACEAE \\
\hline Spiranthes lacera & SLENDER LADIES' TRESSES & ORCHIDACEAE \\
\hline Spiranthes laciniata & FRINGE-LIP LADIES' TRESSES & ORCHIDACEAE \\
\hline Spiranthes longilabris & GIANT SPIRALORCHID & ORCHIDACEAE \\
\hline Spiranthes odorata & FRAGRANT LADIES' TRESSES & ORCHIDACEAE \\
\hline Spiranthes praecox & GRASS-LEAVED LADIES' TRESSES & ORCHIDACEAE \\
\hline Spiranthes tuberosa & LEAST LADIES' TRESSES & ORCHIDACEAE \\
\hline Spiranthes vernalis & UPLAND LADIES' TRESSES & ORCHIDACEAE \\
\hline Sporobolus asper var. asper & TALL DROPSEED & POACEAE \\
\hline Sporobolus clandestinus & HAIRY DROPSEED & POACEAE \\
\hline Sporobolus indicus & SMUTGRASS & POACEAE \\
\hline
\end{tabular}


Table C1. Plant Species, with Common Name and Family, from the Limited Use Area, Vernon Ranger District, Kisatchie National Forest, Louisiana--Continued

\begin{tabular}{|c|c|c|}
\hline Plant Species & Common Name & Eamily \\
\hline Sporobolus junceus & PINEYWOODS DROPSEED & POACEAE \\
\hline Sporobolus neglectus & PUFFSHEATH DROPSEED & POACEAE \\
\hline Sporobolus vaginiflorus & POVERTY DROPSEED & POACEAE \\
\hline Stachys agraria & MOUSEEAR & LAMIACEAE \\
\hline Stellaria media & COMMON CHICKWEED & CARYOPHYLLACEAE \\
\hline Stenanthium gramineum & FEATHERBELLS & LILIACEAE \\
\hline Stenotaphrum secundatum & ST. AUGUSTINE GRASS & POACEAE \\
\hline Stillingia sylvatica & QUEEN'S DELIGHT & EUPHORBIACEAE \\
\hline Stipa avenacea & BLACKSEED NEEDLEGRASS & POACEAE \\
\hline Strophostyles leiosperma & SLICKSEED FUZZYBEAN & FABACEAE \\
\hline Strophostyles umbellata & PINK FUZZYBEAN & FABACEAE \\
\hline Stylisma aquatica & STYLISMA & CONVOLVULACEAE \\
\hline Stylisma humistrata & STYLISMA & CONVOLVULACEAE \\
\hline Stylisma patens & STYLISMA & CONVOLVULACEAE \\
\hline \multicolumn{3}{|l|}{ Stylisma pickeringii } \\
\hline var. pattersonii & STYLISMA & CONVOLVULACEAE \\
\hline Stylisma villosa & STYLISMA & CONVOLVULACEAE \\
\hline Stylodon carneus & CAROLINA FALSE VERVAIN & VERBENACEAE \\
\hline Stylosanthes biflora & PENCIL FLOWER & FABACEAE \\
\hline Styrax americana & LITTLE SNOWBELL & STYRACACEAE \\
\hline Styrax grandifolia & BIG SNOWBELL & STYRACACEAE \\
\hline Symplocos tinctoria & HORSESUGAR & SYMPLOCACEAE \\
\hline Talinum calycinum & LARGEFLOWER FAMEFLOWER & PORTULACEAE \\
\hline Taxodium distichum & BALD CYPRESS & TAXODIACEAE \\
\hline Tephrosia florida & FLORIDA HOARYPEA & FABACEAE \\
\hline Tephrosia onobrychioides & MULTIBLOOM HOARYPEA & FABACEAE \\
\hline Tephrosia virginiana & GOAT'S RUE & FABACEAE \\
\hline Tetragonotheca ludoviciana & NERVERAY & ASTERACEAE \\
\hline Teucrium canadense & GERMANDER & LAMIACEAE \\
\hline Thalictrum dasycarpum & MEADOW RUE & RANUNCULACEAE \\
\hline Thelypteris hexagonoptera & BROAD BEECH FERN & THELYPTERIDACEAE \\
\hline Thelypteris kunthii & WIDESPREAD MAIDEN FERN & THELYPTERIDACEAE \\
\hline \multicolumn{3}{|l|}{ Tilia americana } \\
\hline var. americana & AMERICAN BASSWOOD & TILIACEAE \\
\hline Tillandsia usneoides & SPANISH MOSS & BROMELLIACEAE \\
\hline Tipularia discolor & CRANEFLY ORCHID & ORCHIDACEAE \\
\hline Torilis arvensis & HEDGE PARSLEY & APIACEAE \\
\hline Toxicodendron pubescens & POISON OAK & ANACARDIACEAE \\
\hline Toxicodendron radicans & POISON IVY & ANACARDIACEAE \\
\hline Toxicodendron vernix & POISON SUMAC & ANACARDIACEAE \\
\hline Trachelospermum difforme & CLIMBING DOG BANE & APOCYNACEAE \\
\hline
\end{tabular}


Table C1. Plant Species, with Common Name and Family, from the Limited Use Area, Vernon Ranger District, Kisatchie National Forest, Louisiana--Continued

\begin{tabular}{|c|c|c|}
\hline Plant Species & Common Name & Eamily \\
\hline Tradescantia hirsutiflora & HAIRY SPIDERWORT & COMMELINACEAE \\
\hline Tradescantia occidentalis & SMALL-FLOWERED SPIDERWORT & COMMELINACEAE \\
\hline Tradescantia ohioensis & COMMON SPIDERWORT & COMMELINACEAE \\
\hline Tradescantia paludosa & SPIDERWORT & COMMELINACEAE \\
\hline Tradescantia reverchonii & DOWNY SPIDERWORT & COMMELINACEAE \\
\hline Tragia betonicifolia & NOSEBURN & EUPHORBIACEAE \\
\hline Tragia cordata & VINE NOSEBURN & EUPHORBIACEAE \\
\hline Tragia smallii & SHORT NOSEBURN & EUPHORBIACEAE \\
\hline Tragia urens & NARROW-LEAF NOSEBURN & EUPHORBIACEAE \\
\hline Tragia urticifolia & COMMON NOSEBURN & EUPHORBIACEAE \\
\hline Triadenum tubulosum & TURF ST. JOHN'S WORT & CLUSIACEAE \\
\hline Triadenum virginicum & MARSH ST. JOHN'S WORT & CLUSIACEAE \\
\hline Triadenum walteri & MARSH ST. JOHN'S WORT & CLUSIACEAE \\
\hline Trichostema dichotomum & FORKED BLUECURLS & LAMIACEAE \\
\hline Trichostema setaceum & NARROWLEAF BLUECURLS & LAMIACEAE \\
\hline Tridens ambiguus & PINEBARREN TRIDENS & POACEAE \\
\hline Tridens chapmanii & CHAPMAN PURPLETOP & POACEAE \\
\hline Tridens flavus & PURPLETOP & POACEAE \\
\hline Tridens strictus & LONGSPIKE TRIDENS & POACEAE \\
\hline Trifolium campestre & FIELD CLOVER & FABACEAE \\
\hline Trifolium carolinianum & CAROLINA CLOVER & FABACEAE \\
\hline Trifolium dubium & SUCKLING CLOVER & FABACEAE \\
\hline Trifolium incarnatum & CRIMSON CLOVER & FABACEAE \\
\hline Trifolium lappaceum & BURDOCK CLOVER & FABACEAE \\
\hline Trifolium pratense & RED CLOVER & FABACEAE \\
\hline Trifolium repens & WHITE CLOVER & FABACEAE \\
\hline Trifolium resupinatum & PERSIAN CLOVER & FABACEAE \\
\hline Trifolium vesiculosum & ARROWLEAF CLOVER & FABACEAE \\
\hline Trillium gracile & SOUTHWEST TRILLIUM & LILIACEAE \\
\hline Trillium ludovicianum & COMMON TRILLIUM & LILIACEAE \\
\hline Triodanis biflora & VENUS'LOOKING GLASS & CAMPANULACEAE \\
\hline Triodanis perfoliata & VENUS' LOOKING GLASS & CAMPANULACEAE \\
\hline Triplasis purpurea & PURPLE SANDGRASS & POACEAE \\
\hline Tripsacum dactyloides & EASTERN GAMAGRASS & POACEAE \\
\hline Trisetum interruptum & PRAIRIE TRISETUM & POACEAE \\
\hline Triticum aestivum & WHEAT & POACEAE \\
\hline Typha angustifolia & NARROWLEAF CATTAIL & TYPHACEAE \\
\hline Typha domingensis & GIANT CATTAIL & TYPHACEAE \\
\hline Typha latifolia & COMMON CATTAIL & TYPHACEAE \\
\hline Ulmus alata & WINGED ELM & ULMACEAE \\
\hline
\end{tabular}


Table C1. Plant Species, with Common Name and Family, from the Limited Use Area, Vernon Ranger District, Kisatchie National Forest, Louisiana--Continued

$\begin{array}{ll}\text { Plant Species } & \text { Common Name } \\ \text { Ulmus americana } & \text { AMERICAN ELM } \\ \text { Ulmus rubra } & \text { SLIPPERY ELM } \\ \text { Utricularia cornuta } & \text { HORNED BLADDERWORT } \\ \text { Utricularia foliosa } & \text { LEAFY BLADDERWORT } \\ \text { Utricularia gibba } & \text { HUMPED BLADDERWORT } \\ \text { Utricularia inflata } & \text { SWOLLEN BLADDERWORT } \\ \text { Utricularia juncea } & \text { SOUTHERN BLADDERWORT } \\ \text { Utricularia radiata } & \text { LITTLE FLOATING BLADDERWORT } \\ \text { Utricularia subulata } & \text { ZIZAG BLADDERWORT } \\ \text { Uvularia sessilifolia } & \text { SESSILE-LEAVED BELLWORT } \\ \text { Vaccinium arboreum } & \text { TREE HUCKLEBERRY } \\ \text { Vaccinium corymbosum } & \text { BLUEBERRY } \\ \text { Vaccinium elliottii } & \text { ELLIOTTS BLUEBERRY } \\ \text { Vaccinium fuscatum } & \text { BAYGALL BLUEBERRY } \\ \text { Vaccinium stamineum } & \text { DEERBERRY } \\ \text { Vaccinium virgatum } & \text { LARGE CLUSTER BLUEBERRY } \\ \text { Valerianella radiata } & \text { CORN SALAD } \\ \text { Verbascum thapsum } & \text { MULLEIN } \\ \text { Verbena bonariensis } & \text { PURPLETOP VERVAIN } \\ \text { Verbena brasiliensis } & \text { BRAZILIAN VERVAIN } \\ \text { Verbena halei } & \text { TEXAS VERVAIN } \\ \text { Verbena montevidensis } & \text { URUGUAYAN VERVAIN } \\ \text { Verbena urticifolia } & \text { WHITE VERVAIN } \\ \text { Verbena xutha } & \text { GULF VERVAIN } \\ \text { Verbesina alternifolia } & \text { WING-STEM CROWN-BEARD } \\ \text { Verbesina helianthoides } & \text { SUNFLOWER-LIKE CROWN-BEARD } \\ \text { Verbesina virginica } & \text { WHITE CROWN-BEARD } \\ \text { Verbesina walteri } & \text { WALTER'S CROWN-BEARD } \\ \text { Vernicia fordii } & \text { TUNGOIL TREE } \\ \text { Vernonia baldwinii } & \text { BALDWIN IRONWEED } \\ \text { Vernonia gigantea } & \text { TALL IRONWEED } \\ \text { Vernonia missurica } & \text { MISSOURI IRONWEED } \\ \text { Vernonia texana } & \text { TEXAS IRONWEED } \\ \text { Vernonia x peralta } & \text { IRONWEED } \\ \text { Veronica arvensis } & \text { CORN SPEEDWELL } \\ \text { Veronica peregrina } & \text { NECKWEED } \\ \text { Veronica persica } & \\ \text { Vetiveria zizanioides } & \text { VETTVRER SPEEDWELL } \\ \text { Viburnum acerifolium } & \end{array}$

Eamily

ULMACEAE

ULMACEAE

LENTIBULARIACEAE

LENTIBULARIACEAE

LENTIBULARIACEAE

LENTIBULARIACEAE

LENTIBULARIACEAE

LENTIBULARIACEAE

LENTIBULARIACEAE

LILIACEAE

ERICACEAE

ERICACEAE

ERICACEAE

ERICACEAE

ERICACEAE

ERICACEAE

VALERIANACEAE

VERBENACEAE

VERBENACEAE

VERBENACEAE

VERBENACEAE

VERBENACEAE

VERBENACEAE

VERBENACEAE

ASTERACEAE

ASTERACEAE

ASTERACEAE

ASTERACEAE

EUPHORBIACEAE

ASTERACEAE

ASTERACEAE

ASTERACEAE

ASTERACEAE

ASTERACEAE

SCROPHULARIACEAE

SCROPHULARIACEAE

SCROPHULARIACEAE

POACEAE

CAPRIFOLIACEAE 
Table C1. Plant Species, with Common Name and Family, from the Limited Use Area, Vernon Ranger District, Kisatchie National Forest, Louisiana--Continued

Plant Species

Viburnum dentatum var. dentatum

Viburnum dentatum var. scabrellum

Viburnum nudum var. cassinoides

Viburnum nudum var. nudum

Viburnum prunifolium

Viburnum rufidulum

Vicia caroliniana

Vicia ludoviciana

Vicia minutiflora

Vicia sativa

Vicia villosa

Vinca major

Viola bicolor

Viola esculenta

Viola lanceolata

Viola langloisii

Viola palmata var. triloba

Viola palmata var. palmata

Viola pedata

Viola pratincola

Viola primulifolia

Viola sororia

Viola walteri

Vitis aestivalis

Vitis cinera

Vitis lincecunii

Vitis rotundifolia

Vulpia myuros

Vulpia octoflora

Wahlenbergia marginata

Wisteria frutescens

Wisteria sinensis

Woodwardia areolata

Woodwardia virginica

Xanthium strumarium

Xanthorhiza simplicissima
Common Name

Eamily

ARROW-WOOD

CAPRIFOLIACEAE

ARROW-WOOD

CAPRIFOLIACEAE

WITHE-ROD

CAPRIFOLIACEAE

POSSUM HAW

CAPRIFOLIACEAE

BLACK HAW

RUSTY BLACK HAW

CAPRIFOLIACEAE

CAPRIFOLIACEAE

CAROLINA VETCH

FABACEAE

LOUISIANA VETCH

PYGMYFLOWER VETCH

COMMON VETCH

WINTER VETCH

PERIWINKLE

FIELD PANSY

SALAD VIOLET

BOG WHITE VIOLET

BAYOU VIOLET

THREE-LOBED VIOLET

EARLY BLUE VIOLET

BIRD-FOOT VIOLET

BLUE PRAIRIE VIOLET

WHITE VIOLET

MEADOW VIOLET

STEMMED BLUE VIOLET

SUMMER GRAPE

GRAY GRAPE

POST OAK GRAPE

MUSCADINE

RATTAIL SIXWEEKSGRASS

COMMON SIXWEEKSGRASS

WAHLENBERGIA

AMERICAN WISTERIA

CHINESE WISTERIA

NETTED CHAIN FERN

VIRGINIA CHAIN FERN

COCKLEBUR

YELLOW ROOT
FABACEAE

FABACEAE

FABACEAE

FABACEAE

APOCYNACEAE

VIOLACEAE

VIOLACEAE

VIOLACEAE

VIOLACEAE

VIOLACEAE

VIOLACEAE

VIOLACEAE

VIOLACEAE

VIOLACEAE

VIOLACEAE

VIOLACEAE

VITACEAE

VITACEAE

VITACEAE

VITACEAE

POACEAE

POACEAE

CAMPANULACEAE

FABACEAE

FABACEAE

BLECHNACEAE

BLECHNACEAE

ASTERACEAE

RANUNCULACEAE 
Table C1. Plant Species, with Common Name and Family, from the Limited Use Area, Vernon Ranger District, Kisatchie National Forest, Louisiana--Continued

\begin{tabular}{lll} 
Plant Species & Common Name & Eamily \\
Xyris ambigua & YELLOW-EYED GRASS & XYRIDACEAE \\
Xyris baldwiniana & YELLOW-EYED GRASS & XYRIDACEAE \\
Xyris caroliniana & CAROLINA YELLOW-EYED GRASS & XYRIDACEAE \\
Xyris difformis var. curtisii & YELLOW-EYED GRASS & XYRIDACEAE \\
Xyris difformis var. difformis & YELLOW-EYED GRASS & XYRIDACEAE \\
Xyris drummondii & SMALL YELLOW-EYED GRASS & XYRIDACEAE \\
Xyris jupicai & YELLOW-EYED GRASS & XYRIDACEAE \\
Xyris laxifolia & & \\
\multicolumn{1}{c}{ var. iridifolia } & IRISLEAF YELLOW-EYED GRASS & XYRIDACEAE \\
Xyris louisianica & KRAL'S YELLOW-EYED GRASS & XYRIDACEAE \\
Xyris platylepis & YELLOW-EYED GRASS & XYRIDACEAE \\
Xyris scabrifolia & YELLOW-EYED GRASS & XYRIDACEAE \\
Xyris stricta & PINELAND YELLOW-EYED GRASS & XYRIDACEAE \\
Xyris torta & TWISTED YELLOW-EYED GRASS & XYRIDACEAE \\
Youngia japonica & JAPANESE HAWKWEED & ASTERACEAE \\
Yucca aloifolia & SPANISH DAGGER & AGAVACEAE \\
Yucca louisianensis & LOUISIANA YUCCA & AGAVACEAE \\
Zanthoxylum clava-herculis & TOOTHACHE TREE & RUTACEAE \\
Zea mays & CORN & POACEAE \\
Zephyranthes candida & FALL CROCUS & LILIACEAE \\
Zigadenus densus & BLACK DEATHCAMAS & LILIACEAE \\
Zizaniopsis miliacea & SOUTHERN WILDRICE & POACEAE \\
Zizia aurea & GOLDEN ALEXANDERS & APIACEAE \\
Zornia bracteata & VIPERINA & FABACEAE \\
& &
\end{tabular}


Table C2. Plant Species and vegetational type(s) where found in the Limited Use Area, Vernon Ranger District, Kisatchie National Forest, Louisiana

$$
\left[^{*}=\text { reported from Vernon Parish and in the LUA; }{ }^{* *}=\right.\text { reported from Fort Polk and in the LUA.] }
$$

Species bog haygall savan sandy riparian $\operatorname{mix}$ longleaf dist swamp water Notes

Acacia angustissima

Acalypha gracilens

Acalypha rhomboidea

Acanthospermum australe

Acer barbatum

Acer negundo

Acer rubrum

var drummondii

Acer rubrum var rubrum

Acer saccharinum

Acer saccharum

Achillea millefolium

Acmella oppositifolia

var. repens

Aeschynomene indica

Aesculus pavia

Agalinis fasciculata

Agalinis oligophylla

Agalinis pinetorum

Agalinis purpurea

Agalinis tenuifolia

Agalinis viridis

Ageratina altissima

Agrimonia microcarpa

Agrostis elliottiana

Agrostis hyemalis

Agrostis perennans

Aira elegans

Albizia julibrissin

Aletris aurea

Aletris farinosa

Allium canadense

var mobilense

Allium canadense

var. canadense

Alnus serrulata

Alopecurus carolinianus

Alophia drummondii

Alternanthera caracasana

Amaranthus viridis

Ambrosia artemisiifolia

Ambrosia bidentata

Ambrosia psilostachya 
Table C2. Plant Species and vegetational type(s) where found in the Limited Use Area, Vernon Ranger District, Kisatchie National Forest, Louisiana--Continued

Species bog baygall_savan sandy riparian mix longleaf dist swamp water Notes

Ambrosia trifida

Amelanchier arborea

Ammannia coccinea

Amorpha paniculata

Ampelopsis arborea

Amsonia ludoviciana

Amsonia rigida

Amsonia

tabernaemontana

Anagalis arvensis

Anagallis minima

Andropogon gerardii

Andropogon glomeratu

Andropogon gyrans

Andropogon liebmannii

Andropogon ternarius

Andropogon virginicus

Antennaria parlinii ssp. fallax

Anthaenantia villosa

Anthaenantia rufa

Apios americana

Apocynum cannabinum

Apteria aphylla

Aralia spinosa

Arisaema dracontium

Arisaema triphyllum

Arisaema triphyllum ssp. pusilla

Arisaema triphyllum

ssp. quinatum -

Aristida dichotoma

Aristida lanosa

Aristida longespica

var. geniculata

Aristida longespica var. longespica

Aristida oligantha

Aristida palustris

Aristida purpurascens

var. purpurascens

Aristida purpurascens

var. virgata

Aristida ramosissima 
Table C2. Plant Species and vegetation type(s) where found in the Limited Use Area, Vernon Ranger District, Kisatchie National Forest, Louisiana--Continued

Species bog baygall savan sandy riparian mix longleaf dist swamp water Notes

Aristolochia reticulata

Aristolochia serpentaria

Aristolochia tomentosa

Aronia arbutifolia

Arundinaria gigantea

ssp gigantea -

Asclepias amplexicaule

Asclepias longifolia

Asclepias obovata

Asclepias perennis

Asclepias rubra

Asclepias tuberosa

Asclepias variegata

Asclepias verticillata

Asclepias viridiflora

Asclepias viridis

Asimina parviflora

Asimina triloba

Asplenium platyneuron

Aster drummondii

Aster dumosus

Aster fragilis

Aster lanceolatus

Aster lateriflorus

Aster paludosus

ssp. hemisphericus -

Aster patens

Aster pilosus

Aster sericeus

var. microphyllus

Aster subulatus

Aster subulatus

var. ligulatus

Aster umbellatus

var. latifolius

Athyrium felix-femina

Aureolaria flava

Aureolaria grandiflora

Aureolaria pectinata

Aureolaria virginica

Avena sativa

Axonopus affinis

Axonopus furcatus

Baccharis halimifolia 
Table C2. Plant Species and vegetation type(s) where found in the Limited Use Area, Vernon Ranger District, Kisatchie National Forest, Louisiana--Continued

Species bog baygall savan sandy riparian mix longleaf dist swamp water Notes

Bacopa caroliniana

Baptisia alba

var. macrophylla

Baptisia bracteata

var. laevicaulis

Baptisia bracteata

var. leucophaea

Baptisia nuttalliana

Bartonia paniculata

Berchemia scandens

Berlandiera pumila

Berlandiera $\mathrm{x}$

betonicifolia

Betula nigra

Bidens aristosa

Bidens bipinnata

Bidens discoidea

Bidens frondosa

Bigelowia nuttallii

Bignonia capreolata

Boehmeria cylindrica

Boerhaavia erecta

Boltonia diffusa

Bothriochloa ischaemum

Bothriochloa laguroides

ssp. torreyana

Botrychium biternatum

Botrychium virginiana

Brachiaria platyphylla

Brachyelytrum erectum

Brasenia schreberi

Brassica juncea

Brickellia eupatorioides

Briza minor

Bromus japonicus

Bromus pubescens

Bromus racemosus

Bromus tectorum

Bromus unioloides

Brunnichia ovata

Buchnera americana

Bulbostylis barbata 
Table C2. Plant Species and vegetation type(s) where found in the Limited Use Area, Vernon Ranger District, Kisatchie National Forest, Louisiana--Continued

\begin{tabular}{|c|c|c|c|c|c|c|c|c|c|c|c|}
\hline Species & bos & baygall & savan & sandy & riparian & $\operatorname{mix}$ & longleaf & dist & swamp & water & Notes \\
\hline Bulbostylis capillaris & - & - & - & + & - & - & + & - & - & - & - \\
\hline Bulbostylis ciliatifolia & - & - & - & + & - & - & + & - & - & - & - \\
\hline Bumelia lanuginosa & - & - & - & + & + & + & + & - & - & - & - \\
\hline Bumelia lycioides & - & - & - & - & - & - & - & - & - & - & $*$ \\
\hline Burmannia biflora & + & + & + & - & - & - & - & - & - & - & - \\
\hline Burmannia capitata & + & + & + & - & - & - & - & - & - & - & - \\
\hline Cabomba caroliniana & - & - & - & - & - & - & - & - & - & + & - \\
\hline Cacalia ovata & + & + & + & - & - & + & + & - & + & - & - \\
\hline Cacalia plantaginea & + & + & + & - & - & + & + & - & + & - & - \\
\hline Callicarpa americana & - & - & + & + & + & + & + & - & - & - & - \\
\hline Callirhoe papaver & - & - & - & + & - & + & + & - & - & - & - \\
\hline Callitriche heterophylla & - & - & - & - & - & - & - & + & + & + & - \\
\hline Callitriche nuttallii & - & - & - & - & - & - & - & + & + & - & - \\
\hline Callitriche peploides & - & - & - & - & - & - & - & + & + & - & - \\
\hline Calopogon barbatus & - & - & + & - & - & - & - & - & - & - & - \\
\hline Calopogon pallidus & - & - & + & - & - & - & - & - & - & - & - \\
\hline Calopogon tuberosus & + & + & + & - & - & - & - & - & - & - & - \\
\hline Calyptocarpus vialis & - & - & - & - & - & - & - & + & - & - & - \\
\hline Camelina microcarpa & - & - & - & - & - & - & - & + & - & - & - \\
\hline Campsis radicans & - & - & - & - & + & + & - & + & + & - & - \\
\hline Cardamine bulbosa & - & - & - & - & - & - & - & - & + & - & - \\
\hline Cardamine hirsuta & - & - & - & - & - & - & - & + & - & - & - \\
\hline Cardamine parviflora & - & - & - & - & - & - & - & + & - & - & - \\
\hline Carex alata & - & - & - & - & + & + & - & + & + & - & - \\
\hline Carex albolutescens & - & - & - & - & + & + & - & + & + & - & - \\
\hline Carex amphibola & - & - & - & - & + & + & - & - & - & - & - \\
\hline Carex atlantica & - & - & - & - & + & + & - & - & - & - & - \\
\hline Carex caroliniana & - & - & + & - & + & + & - & - & - & - & - \\
\hline Carex cephalophora & - & + & + & - & + & + & - & - & - & - & - \\
\hline Carex cherokeensis & - & - & - & + & - & + & + & + & - & - & - \\
\hline Carex comosa & + & + & + & - & - & - & - & - & - & - & - \\
\hline Carex complanata & - & - & - & - & + & + & - & - & - & - & - \\
\hline Carex corrugata & - & - & - & - & + & + & - & - & - & - & - \\
\hline Carex crebriflora & - & - & - & - & + & + & - & - & - & - & - \\
\hline Carex debilis & - & + & - & - & + & + & - & - & - & - & - \\
\hline Carex digitalis & - & + & + & - & + & + & - & - & - & - & - \\
\hline Carex flaccosperma & - & - & - & - & + & + & - & + & - & - & - \\
\hline Carex folliculata & + & + & + & - & - & - & - & - & - & - & - \\
\hline Carex frankii & + & + & + & - & - & - & - & - & + & - & - \\
\hline Carex glaucescens & + & + & + & - & - & - & - & - & - & - & - \\
\hline
\end{tabular}


Table C2. Plant Species and vegetation type(s) where found in the Limited Use Area, Vernon Ranger District, Kisatchie National Forest, Louisiana--Continued

Species bog baygall savan sandy riparian mix longleaf dist swamp water Notes

Carex glaucodea

Carex howei

Carex intumescens

Carex joorii

Carex leptalea

Carex longii

Carex lurida

Carex microdonta

Carex muhlenbergii

Carex nigromarginata

Carex oxylepis

Carex rosea

Carex tenax

Carex tribuloides

Carex verrucosa

Carpinus caroliniana

Carya alba

Carya aquatica

Carya cordiformis

Carya glabra

Carya glabra

var. hirsuta

Carya illinoensis

Carya myristicaeformis

Carya ovata

Carya texana

Cassia fasciculata

Cassia marilandica

Cassia nictitans

Cassia occidentalis

Castanea pumila

Catalpa bignonioides

Ceanothus americanus

Celtis laevigata

Celtis laevigata var. reticulata

Celtis tenuifolia

Cenchrus incertus

Centella erecta

Centrosema virginiana

Cephalanthus

occidentalis

Cerastium glomeratum 
Table C2. Plant Species and vegetation type(s) where found in the Limited Use Area, Vernon Ranger District, Kisatchie National Forest, Louisiana--Continued

\section{Species}

bog baygall savan sandy riparian mix longleaf dist swamp water Notes

Ceratophyllum demersum

Cercis canadensis

Chaerophyllum tainturieri

Chamaesyce cordifolia

Chamaesyce maculata

Chamaesyce nutans

Chamaesyce serpens

Chaptalia tomentosa

Chasmanthium latifolium

Chasmanthium laxum

Chasmanthium

sessiliflorum

Chenopodium

ambrosioides

Chionanthus virginica

Chloris virgata

Chrysopsis graminifolia

Chrysopsis mariana

Chrysopsis pilosa

Ciclospermum

leptophyllum

Cirsium caroliniana

Cirsium horridulum

Claytonia virginica

Cleistes divaricata

Clematis crispa

Clematis reticulata

Clematis terniflora

Clematis virginiana

Cleome hassleriana

Clitoria mariana

Cnidoscolus texanus

Cocculus carolina

Coelorachis cylindrica

Coelorachis rugosa

Colocasia antiquorum

Commelina communis

Commelina diffusa

Commelina erecta

Commelina virginica

Conyza bonariensis

Conyza canadensis

var. canadense

Conyza canadensis

var. pusilla 
Table C2. Plant Species and vegetation type(s) where found in the Limited Use Area, Vernon Ranger District, Kisatchie National Forest, Louisiana--Continued

\begin{tabular}{|c|c|c|c|c|c|c|c|c|c|c|c|}
\hline Species & bog & bay & savan & sandy & riparian & $\operatorname{mix}$ & longleaf & dist & swamp & water & Notes \\
\hline Coreopsis gladiata & + & + & + & - & - & - & - & - & - & - & - \\
\hline Coreopsis lanceolata & - & - & - & + & - & + & + & - & - & - & - \\
\hline Coreopsis linifolia & + & + & + & - & - & - & - & - & - & - & - \\
\hline Coreopsis pubescens & - & - & - & + & - & + & + & - & - & - & - \\
\hline Coreopsis tinctoria & - & - & - & - & - & - & - & + & - & - & - \\
\hline Coreopsis tripteris & + & + & + & - & - & - & - & - & - & - & - \\
\hline Cornus drummondii & - & + & + & - & - & - & - & - & + & - & - \\
\hline Cornus florida & - & - & - & + & + & + & + & - & - & - & - \\
\hline Cornus foemina & - & + & + & - & - & - & - & - & + & - & - \\
\hline Coronopus didymus & - & - & - & - & - & - & - & + & - & - & - \\
\hline Cortaderia dioica & - & - & - & - & - & - & - & + & - & - & - \\
\hline Crataegus berberifolia & - & - & - & - & - & - & - & - & - & - & $* *$ \\
\hline Crataegus brachyacantha & - & - & - & - & - & - & - & - & - & - & $* *$ \\
\hline Crataegus crus-gallii & - & - & - & + & + & + & + & - & - & - & - \\
\hline Crataegus marshallii & - & - & - & + & + & + & + & - & - & - & - \\
\hline Crataegus opaca & - & - & - & - & - & - & - & - & + & - & - \\
\hline Crataegus spathulata & - & - & - & + & + & + & + & - & - & - & - \\
\hline Crataegus uniflora & - & - & - & + & + & + & + & - & - & - & - \\
\hline Crataegus viridis & - & - & + & - & - & - & - & - & + & - & - \\
\hline Croptilon divaricatum & - & - & - & + & - & - & - & - & - & - & - \\
\hline Crotalaria lanceolata & - & - & - & - & - & - & - & + & - & - & - \\
\hline Crotalaria sagittalis & - & - & - & + & - & + & + & - & - & - & - \\
\hline Croton argyranthemus & - & - & - & - & - & - & - & - & - & - & $*$ \\
\hline Croton capitatus & - & - & - & - & - & - & - & + & - & - & - \\
\hline Croton glandulosus & - & - & - & - & - & - & - & + & - & - & - \\
\hline Croton michauxii & - & - & - & + & - & + & + & - & - & - & - \\
\hline Croton monanthogynus & - & - & - & + & - & - & + & + & - & - & - \\
\hline Croton willdenowii & - & - & - & + & - & - & - & - & - & - & - \\
\hline Ctenium aromaticum & + & + & + & - & - & - & - & - & - & - & - \\
\hline Cuphea carthagenensis & - & - & - & - & - & - & - & + & - & - & - \\
\hline Cuscuta compacta & + & + & + & - & + & + & + & + & - & - & - \\
\hline Cynodon dactylon & - & - & - & - & - & - & - & + & - & - & - \\
\hline \multicolumn{12}{|l|}{ Cynoglossum } \\
\hline virginianum & - & - & - & - & + & - & - & - & - & - & - \\
\hline Cyperus acuminatus & - & - & - & - & - & - & - & + & - & - & - \\
\hline Cyperus albomarginatus & - & - & - & - & - & - & - & + & - & - & - \\
\hline Cyperus brevifolius & - & - & - & - & - & - & - & + & - & - & - \\
\hline Cyperus compressus & - & - & - & - & - & - & - & + & - & - & - \\
\hline Cyperus erythrorhizos & - & - & - & - & - & - & - & + & - & - & - \\
\hline Cyperus flavescens & - & - & - & - & - & - & - & + & - & - & - \\
\hline Cyperus globulosus & - & - & + & + & + & + & + & - & - & - & - \\
\hline
\end{tabular}


Table C2. Plant Species and vegetation type(s) where found in the Limited Use Area, Vernon Ranger District, Kisatchie National Forest, Louisiana--Continued

Species bog baygall savan sandy riparian mix longleaf dist swamp water Notes

Cyperus grayioides

Cyperus haspan

Cyperus iria

Cyperus odoratus

Cyperus ovularis

Cyperus polystachyos var. polystachyos

Cyperus polystachyos var. texana

Cyperus pseudovegetus

Cyperus reflexus

Cyperus retrofractus

Cyperus retrorsus

Cyperus rotundus

Cyperus sesquiflorus

Cyperus strigosus

Cyperus surinamensis

Cyperus tenuifolius

Cyperus uniflorus

Cyperus virens

Cypripedium

kentuckiense

Cyrilla racemiflora

Dactylis glomerata

Dalea candida

Dalea purpurea

Danthonia spicata

Datura stramonium

Daucus pusillus

Delphenium vimineum

Delphinium carolinianum

Desmanthus illinoiensis

Desmodium ciliare

Desmodium glabellum

Desmodium glutinosum

Desmodium laevigatum

Desmodium lineatum

Desmodium nudiflorum

Desmodium obtusum

Desmodium paniculatum

Desmodium pauciflorum 
Table C2. Plant Species and vegetation type(s) where found in the Limited Use Area, Vernon Ranger District, Kisatchie National Forest, Louisiana--Continued

Species hog baygall savan sandy riparian mix longleaf dist swamp water Notes

Desmodium rotundifolium

Desmodium strictum

Desmodium viridiflorum

Dichondra carolinensis

Dichromena colorata

Dichromena latifolia

Dicliptera brachiata

Digitaria ciliaris

Digitaria filiformis

Digitaria ischaemum

Digitaria sanguinalis

Digitaria villosa

Digitaria violascens

Diodia teres

Diodia virginiana

Dioscorea villosa

Diospyros virginiana

Draba brachycarpa

Dracopsis amplexicaulis

Drosera brevifolia

Drosera capillaris

Drymaria cordata

Duchesnea indica

Echinacea angustifolia

Echinacea pallida

Echinacea purpurea

Echinacea sanguinea

Echinochloa colona

Echinochloa crus-galli

Echinochloa walteri

Echinodorus cordifolius

Eclipta prostrata

Egeria densa

Eichhornia crassipes

Eleocharis baldwinii

Eleocharis elliptica

Eleocharis equisetoides

Eleocharis flavescens

Eleocharis microcarpa

Eleocharis obtusa 
Table C2. Plant Species and vegetation type(s) where found in the Limited Use Area, Vernon Ranger District, Kisatchie National Forest, Louisiana--Continued

Species bog baygall_savan sandy riparian mix longleaf dist swamp water Notes

Eleocharis quadrangulata

Eleocharis tortilis

Eleocharis tuberculosa

Elephantopus

carolinianus

Elephantopus nudatus

Elephantopus

tomentosus

Eleusine indica

Elymus virginicus

Epifagus virginiana

Eragrostis cilianensis

Eragrostis ciliaris

Eragrostis curvula

Eragrostis elliottii

Eragrostis glomerata

Eragrostis hypnoides

Eragrostis lugens

Eragrostis pectinacea

Eragrostis pilosa

Eragrostis refracta

Eragrostis secundiflora

Eragrostis spectabilis

Erechtites hieracifolia

Eremochloa ophiuroides

Erianthus contortus

Erianthus giganteus

Erianthus strictus

Erigeron annuus

Erigeron philadelphicus

Erigeron pulchellus

Erigeron strigosus

Erigeron tenuis

Eriocaulon cinereum

Eriocaulon compressum

Eriocaulon decangulare

Eriocaulon texense

Eriogonum longifolium

Eryngium integrifolium

Eryngium prostratum

Eryngium yuccifolium

Erythrina herbacea

$\begin{array}{rrrrrrr}- & - & - & - & - & - & - \\ + & + & + & - & - & - & - \\ + & + & + & - & - & - & - \\ - & - & - & + & + & + & + \\ + & + & + & - & + & - & -\end{array}$


Table C2. Plant Species and vegetation type(s) where found in the Limited Use Area, Vernon Ranger District, Kisatchie National Forest, Louisiana--Continued

Species bog baygall savan sandy riparian mix longleaf dist swamp water Notes

Euonymus americanus

Eupatorium album

Eupatorium capillifolium

Eupatorium coelestinum

Eupatorium compositifolium

Eupatorium fistulosum

Eupatorium glaucescens

Eupatorium hyssopifolium

Eupatorium lancifolium

Eupatorium leucolepis

Eupatorium perfoliatum

Eupatorium pinnatifidum

Eupatorium rotundifolium

var. rotundifolium

Eupatorium rotundifolium var. scabridum

Eupatorium semiserratum

Eupatorium serotinum

Euphorbia bicolor

Euphorbia corollata

Euphorbia heterophylla

Euphorbia marginata

Euphorbia spathulata

Euthamia

gymnospermoides

Euthamia leptocephala

Facelis retusa

Fagus grandifolia

Festuca arundinacea

Ficus carica

Fimbristylis autumnalis

Fimbristylis castanea

Fimbristylis miliacea

Fimbristylis tomentosa

Fimbristylis vahlii

Fragaria virginiana

Fraxinus americana

Fraxinus caroliniana

Fraxinus pennsylvanica

Froelichia floridana

Froelichia gracilis 
Table C2. Plant Species and vegetation type(s) where found in the Limited Use Area, Vernon Ranger District, Kisatchie National Forest, Louisiana--Continued

Species

Fuirena bushii

Fuirena pumila

Fuirena simplex

Fuirena squarrosa

Gaillardia aestivalis

var. aestivalis

Gaillardia aestivalis var. flavovirens

Gaillardia pulchella

Galactia erecta

Galactia regularis

Galactia volubilis

Galium aparine

Galium circaezans

Galium obtusum

Galium pilosum

Galium tinctorium

Galium uniflorum

Galium virgatum

Gamochaeta

pensylvanica

Gamochaeta purpurea

Gaura lindheimeri

Gaura longiflora

Gelsemium sempervirens

Gentiana saponaria

Geranium carolinianum

Geranium dissectum

Geum canadense

Gillenia stipulacea

Glandularia canadensis

Glandularia pulchella

Glandularia tenuisecta

Gleditsia aquatica

Gleditsia triacanthos

Glottidium vesicarium

Glyceria declinata

Gnaphalium helleri

Gnaphalium obtusifolium

Gratiola brevifolia

Gratiola neglecta bog baygall savan sandy riparian mix longleaf dist swamp water Notes

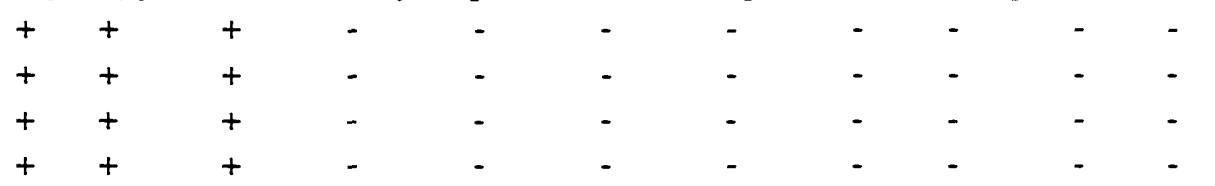


Table C2. Plant Species and vegetation type(s) where found in the Limited Use Area, Vernon Ranger District, Kisatchie National Forest, Louisiana--Continued

Species bog baygall savan sandy riparian mix longleaf dist swamp water Notes

Gratiola pilosa

Gratiola virginiana

Gymnopogon ambiguus

Gymnopogon brevifolius

Habenaria repens

Halesia diptera

Hamamelis virginiana

Hedeoma hispida

Hedera helix

Hedyotis nigricans

Helenium amarum

Helenium autumnale

Helenium drummondii

Helenium flexuosum

Helenium vernale

Helianthemum

carolinianum

Helianthemum georgianum

Helianthus angustifolius

Helianthus debilis

Helianthus hirsutus

Heliopsis gracilis

Heliopsis helianthoides

Heliotropium indicum

Heliotropium tenellum

Herbertia lahue

Heterotheca subaxillaris

Hibiscus moschuetos

ssp. lasiocarpus

Hibiscus moschuetos

ssp. moschuetos

Hieracium gronovii

Holcus lanatus

Hordeum pusillum

Houstonia micrantha

Houstonia purpurea

var. purpurea

Houstonia pusilla

Houstonia rosea

Hydrocotyle

ranunculoides

Hydrocotyle umbellata

Hydrocotyle verticillata

$\begin{array}{lll}+ & + & + \\ - & - & - \\ - & - & + \\ - & - & + \\ - & - & - \\ - & - & - \\ - & - & - \\ - & - & - \\ - & - & - \\ - & - & + \\ - & - & - \\ - & - & - \\ + & + & + \\ - & - & + \\ + & + & +\end{array}$


Table C2. Plant Species and vegetation type(s) where found in the Limited Use Area, Vernon Ranger District, Kisatchie National Forest, Louisiana--Continued

Species bog baygall savan sandy riparian mix longleaf dist swamp water Notes

Hydrolea ovata

Hydrolea uniflora

Hymenocallis eulae

Hymenopappus

artemisiifolius

Hymenopappus

scabiosaeus

Hypericum crux-andreae

Hypericum densiflorum

Hypericum drummondii

Hypericum fasciculatum

Hypericum frondosum

Hypericum galioides

Hypericum gentianoides

Hypericum gymnanthum

Hypericum hypericoides

ssp. hypericoides

Hypericum hypericoides

ssp. multicaulis

Hypericum mutilum

Hypericum nudiflorum

Hypericum prolificum

Hypericum setosum

Hypochoeris glabra

Hypochoeris

microcephala

Hypochoeris radicata

Hypoxis hirsuta

Hypoxis juncea

Hypoxis micrantha

Hypoxis rigida

Hypoxis sessilis

Hyptis alata

Ilex ambigua

Ilex coriacea

Ilex decidua

Ilex longipes

Ilex opaca

Ilex vomitoria

Indigofera miniata

var. leptosephala

Ionactis linariifolius

Ipomoea cordatotriloba 
Table C2. Plant Species and vegetation type(s) where found in the Limited Use Area, Vernon Ranger District, Kisatchie National Forest, Louisiana--Continued

\begin{tabular}{|c|c|c|c|c|c|c|c|c|c|c|c|}
\hline Species & bog & baygall & savan & sandy & riparian & $\operatorname{mix}$ & longleaf & dist & swamp & water & Notes \\
\hline Ipomoea lacunosa & - & - & - & - & - & - & - & + & - & - & - \\
\hline Ipomoea nil & - & - & - & - & - & - & - & + & - & - & - \\
\hline Ipomoea pandurata & - & - & - & + & - & + & + & - & - & - & - \\
\hline Iris virginica & - & - & - & - & - & - & - & - & + & + & - \\
\hline Isoetes melanopoda & - & - & - & - & - & - & - & - & + & + & - \\
\hline Isotria verticillata & - & + & - & - & - & - & - & - & - & - & - \\
\hline Itea virginica & + & + & + & - & - & - & - & - & + & - & - \\
\hline Iva annua & - & - & - & - & - & - & - & + & - & - & - \\
\hline Jacquemontia tamnifolia & - & - & - & - & - & - & - & + & - & - & - \\
\hline Juglans nigra & - & - & - & - & - & - & - & + & - & - & - \\
\hline Juncus acuminatus & - & - & - & - & - & - & - & + & + & - & - \\
\hline Juncus biflorus & - & - & - & - & - & - & - & + & + & - & - \\
\hline Juncus brachycarpus & - & - & - & - & - & - & - & + & + & - & - \\
\hline Juncus bufonius & - & - & - & - & - & - & - & + & - & - & - \\
\hline Juncus capitatus & - & - & - & - & - & - & - & + & - & - & - \\
\hline Juncus coriaceus & - & - & - & - & - & - & - & + & + & + & - \\
\hline Juncus dichotomus & - & - & - & - & - & - & - & + & - & - & - \\
\hline Juncus diffusissimus & - & - & - & - & - & - & - & + & + & - & - \\
\hline Juncus effusus & - & - & - & - & - & - & - & + & + & - & - \\
\hline Juncus elliottii & + & + & + & - & - & - & - & - & - & - & - \\
\hline Juncus marginatus & + & + & + & - & - & - & - & + & - & - & - \\
\hline Juncus nodatus & - & - & - & - & - & - & - & + & + & - & - \\
\hline Juncus polycephalus & + & + & + & - & - & - & - & + & + & + & - \\
\hline Juncus repens & - & - & - & - & - & - & - & - & + & + & - \\
\hline Juncus scirpoides & - & - & - & - & - & - & - & - & + & + & - \\
\hline Juncus tenuis & - & - & - & - & - & - & - & + & - & - & - \\
\hline Juncus trigonocarpus & - & - & - & - & - & - & - & + & + & + & - \\
\hline Juncus validus & - & - & - & - & - & - & - & + & + & - & - \\
\hline Juniperus virginiana & - & - & - & + & + & + & + & + & - & - & - \\
\hline Justicia ovata & - & - & - & - & + & - & - & - & + & + & - \\
\hline Koeleria gerardii & - & - & - & - & - & - & - & + & - & - & - \\
\hline Krigia cespitosa & - & - & - & - & - & - & - & + & - & - & - \\
\hline Krigia dandelion & - & - & - & - & - & + & + & + & - & - & - \\
\hline Krigia virginica & - & - & - & + & - & - & + & - & - & - & - \\
\hline Lachnocaulon anceps & + & + & + & - & - & - & - & - & - & - & - \\
\hline Lachnocaulon digynum & + & + & + & - & - & - & - & - & - & - & - \\
\hline Lactuca canadensis & - & - & - & + & - & + & + & + & - & - & - \\
\hline Lactuca floridana & - & - & - & + & - & + & + & + & - & - & - \\
\hline Lactuca ludoviciana & - & - & - & + & - & + & + & + & - & - & - \\
\hline Lactuca serriola & - & - & - & - & - & - & - & + & - & - & - \\
\hline
\end{tabular}


Table C2. Plant Species and vegetation type(s) where found in the Limited Use Area, Vernon Ranger District, Kisatchie National Forest, Louisiana--Continued

Species. bog baygall savan sandy riparian mix longleaf dist swamp water Notes

Lagenaria siceraria

Lagerstroemia indica

Lamium amplexicaule

Lantana camara

Lathyrus hirsutus

Lathyrus pusillus

Lechea mucronata

Lechea tenuifolia

Leersia oryzoides

Leersia virginica

Lemna aequinoctialis

Lemna minor

Lemna obscura

Lepidium virginicum

Leptochloa fascicularis

Leptochloa scabra

Leptoloma cognatum

Lepurapetalon

spathulatum

Lespedeza capitata

Lespedeza cuneata

Lespedeza hirta

Lespedeza procumbens

Lespedeza repens

Lespedeza striata

Lespedeza stuevei

Lespedeza virginica

Leucospora multifida

Liatris acidota

Liatris aspera

Liatris elegans

Liatris pycnostachya

Liatris spicata

Liatris squarrulosa

\section{-}

-


Table C2. Plant Species and vegetation type(s) where found in the Limited Use Area, Vernon Ranger District, Kisatchie National Forest, Louisiana--Continued

Species bog baygall savan sandy riparian mix longleaf dist swamp water Notes

Lindernia anagallidea

Lindernia dubia

Linum floridanum var. floridana

Linum medium

Linum striatum

Liquidambar styraciflua

Liriodendron styraciflua

Listera australis

Lithospermum

caroliniense

Lithospermum tuberosum

Lobelia appendiculata

Lobelia cardinalis

Lobelia flaccidifolia

Lobelia puberula

Lobelia reverchonii

Lolium perenne

Lonicera japonica

Lonicera sempervirens

Ludwigia alternifolia

Ludwigia decurrens

Ludwigia glandulosa

Ludwigia hirtella

Ludwigia leptocarpa

Ludwigia linearis

Ludwigia palustris

Ludwigia peploides

ssp. peploides +

Ludwigia pilosa

Ludwigia uruguayensis

Lupinus texensis

Luzula bulbosa

Luzula campestris

Luzula echinata

Lycopodium

alopecuroides

Lycopodium appressum

Lycopodium

carolinianum

Lycopodium prostratum

Lycopus rubellus

Lycopus virginicus

Lygodium japonicum

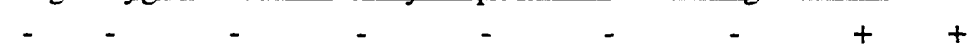

$\begin{array}{rrrrrrr}+ & + & + & + & - & + & + \\ + & + & + & + & - & + & + \\ + & + & + & + & - & + & + \\ - & - & - & + & + & + & + \\ - & - & - & - & - & - & - \\ - & - & - & - & + & - & -\end{array}$


Table C2. Plant Species and vegetation type(s) where found in the Limited Use Area, Vernon Ranger District, Kisatchie National Forest, Louisiana--Continued

Species bog baygall savan sandy riparian mix longleaf dist swamp water Notes

Lyonia ligustrina

Lyonia lucida

Lysimachia radicans

Lythrum alatum

var. lanceolatum

Lythrum lineare

Magnolia grandiflora

Magnolia virginiana

Malaxis unifolia

Malus angustifolia

Manfreda virginica

Marshallia caespitosa

var. caespitosa

Marshallia graminifolia

var. cynanthera

Marshallia trinervia

Matelea carolinensis

Matelea decipiens

Matelea gonocarpos

Mazus pumilus

Mecardonia acuminata

Medicago lupulina

Medicago polymorpha

Medicago sativa

Melanthium virginicum

Melia azedarach

Melica mutica

Melilotus alba

Melilotus indica

Melilotus officinalis

Melochia corchorifolia

Melothria pendula

Micranthemum

umbrosum

Mikania cordifolia

Mikania scandens

Mimosa quadrivalvis

var. angustata

Mimosa quadrivalvis var. hystricina

Mimosa quadrivalvis var. nuttallii

$\begin{array}{ccccc}+ & + & + & - & - \\ + & + & + & - & + \\ - & - & + & - & +\end{array}$


Table C2. Plant Species and vegetation type(s) where found in the Limited Use Area, Vernon Ranger District, Kisatchie National Forest, Louisiana--Continued

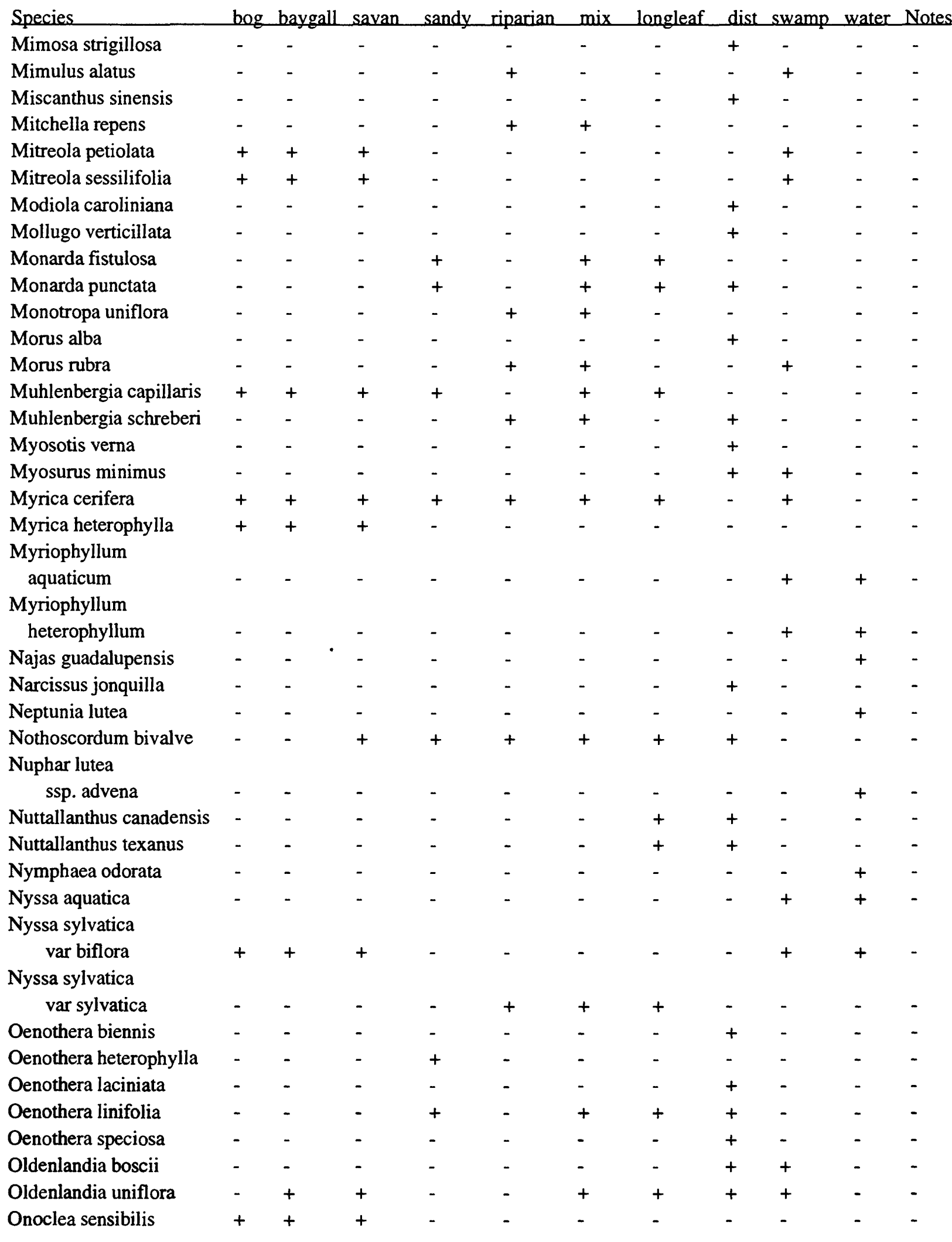


Table C2. Plant Species and vegetation type(s) where found in the Limited Use Area, Vernon Ranger District, Kisatchie National Forest, Louisiana--Continued

Species bog baygall savan sandy riparian mix longleaf dist swamp water Notes

Onosmodium

virginianum

Ophioglossum

crotalophoroides

Ophioglossum

engelmannii

Ophioglossum nudicaule

Oplismenus setarius

Opuntia humifusa

var. humifusa

Opuntia macrorhiza

Orbexilium simplex

Orbexilum pedunculatum

Orobanche uniflora

Oryza sativa

Osmunda cinnamomea

Osmunda regalis

var. spectabilis

Ostrya virginiana

Oxalis corniculata

Oxalis corymbosa

Oxalis dillenii

Oxalis priceae

Oxalis stricta

Oxalis violacea

Oxypolis filiformis

Oxypolis rigidior

Panicum aciculare

Panicum acuminatum

var. acuminatum

Panicum acuminatum var. leucothrix

Panicum acuminatum var. lindheimeri

Panicum acuminatum var. longiligulatum

Panicum anceps

Panicum angustifolium

Panicum boscii

Panicum brachyanthum

Panicum commutatum

Panicum consanguineum

Panicum depauperatum

Panicum dichotomiflorum 
Table C2. Plant Species and vegetation type(s) where found in the Limited Use Area, Vernon Ranger District, Kisatchie National Forest, Louisiana--Continued

Species bog baygall savan sandy riparian mix longleaf dist swamp water Notes

Panicum dichotomum var. dichotomum

Panicum dichotomum var. lucidum

Panicum dichotomum var. nitidum

Panicum dichotomum var. ramulosum

Panicum ensifolium var. curtifolium

Panicum flexile

Panicum gymnocarpon

Panicum hemitomon

Panicum hians

Panicum laxiflorum

Panicum oligosanthes var. oligosanthes

Panicum oligosanthes var. scribnerianum

Panicum ovale

Panicum polyanthes

Panicum ramosum

Panicum ravenelii

Panicum rigidulum var. pubescens

Panicum rigidulum var. rigidulum

Panicum scabriusculum

Panicum scoparium

Panicum sphaerocarpon

Panicum strigosum var. glabrescens

Panicum strigosum var. strigosum

Panicum tenerum

Panicum tenue

Panicum texanum

Panicum verrucosum

Panicum virgatum

Parthenocissus quinquefolia 
Table C2. Plant Species and vegetation type(s) where found in the Limited Use Area, Vernon Ranger District, Kisatchie National Forest, Louisiana--Continued

Species bog baygall savan sandy riparian mix longleaf dist swamp water Notes

Paspalum bifidum

Paspalum dilatatum

Paspalum floridanum

Paspalum laeve

Paspalum notatum

var. saurae

Paspalum plicatulum

Paspalum praecox

Paspalum pubiflorum

Paspalum setaceum

var ciliatifolium

Paspalum setaceum

var muhlenbergii

Paspalum setaceum

var setaceum

Paspalum setaceum

var stramineum

Paspalum setaceum

var supinum

Paspalum urvillei

Passiflora incarnata

Passiflora lutea

Pedicularis canadensis

Peltandra virginica

Penstemon digitalis

Penstemon laxiflorus

Penstemon tubaeflorus

Penthorum sedoides

Perilla frutescens

Persea palustris

Phalaris angusta

Phalaris caroliniana

Phlox divaricata

Phlox drummondii

Phlox pilosa

Phoradendron

tomentosum

Phryma leptostachya

Phyla cuneifolia

Phyla lanceolata

Phyla nodiflora

Phyla $x$ intermedia 
Table C2. Plant Species and vegetation type(s) where found in the Limited Use Area, Vernon Ranger District, Kisatchie National Forest, Louisiana--Continued

Species bog baygall sayan sandy riparian mix longleaf dist swamp water Notes

Phyllanthus caroliniensis

Physalis angulata

Physalis hederifolia

Physalis heterophylla

Physalis pumila

Physalis virginiana

Physostegia digitalis

Physostegia virginiana

Phytolacca americana

Pilea pumila

Pinguicula pumila

Pinus echinata

Pinus elliottii

Pinus glabra

Pinus palustris

Pinus taeda

Planera aquatica

Plantago aristata

Plantago heterophylla

Plantago lanceolata

Plantago virginica

Plantago wrightiana

Platanthera

blephariglottis

Platanthera ciliaris

Platanthera clavellata

Platanthera cristata

Platanthera flava

Platanthera integra

Platanthera nivea

Platanus occidentalis

Pluchea camphorata

Pluchea foetida

Pluchea rosea

Poa annua

Poa autumnalis

Poa chapmaniana

Podophyllum peltatum

Pogonia ophioglossoides

Polygala cruciata

Polygala cymosa

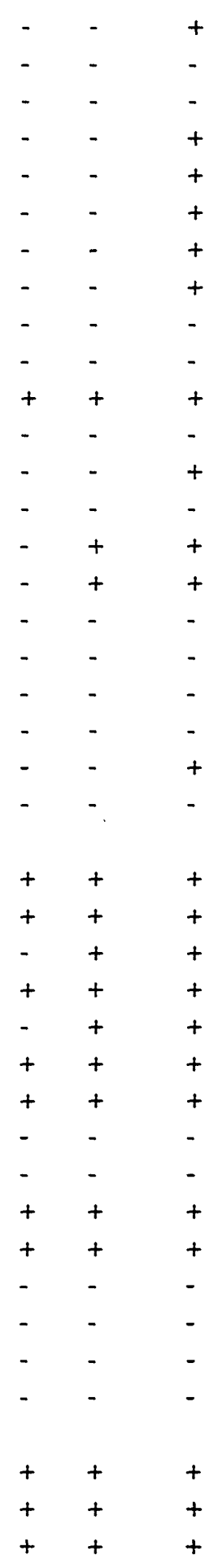


Table C2. Plant Species and vegetation type(s) where found in the Limited Use Area, Vernon Ranger District, Kisatchie National Forest, Louisiana--Continued

\begin{tabular}{|c|c|c|c|c|c|c|c|c|c|c|c|}
\hline Species & bo & baygall & savan & sandy & riparian & $\operatorname{mix}$ & longleaf & dis & swamp & water & Notes \\
\hline Polygala incarnata & - & - & + & + & - & + & + & - & - & - & - \\
\hline Polygala leptocaulis & + & + & + & - & - & - & - & - & - & - & - \\
\hline Polygala mariana & + & + & + & + & - & + & + & - & - & - & - \\
\hline Polygala nana & + & + & + & + & - & + & + & - & - & - & - \\
\hline Polygala polygama & - & - & - & + & - & - & + & - & - & - & - \\
\hline Polygala ramosa & + & + & + & - & - & - & - & - & - & - & - \\
\hline Polygala verticillata & - & - & + & + & + & + & + & - & - & - & - \\
\hline Polygonatum biflorum & - & - & - & - & + & + & - & - & - & - & - \\
\hline Polygonum densiflorum & - & - & - & - & - & - & - & + & + & - & - \\
\hline \multicolumn{12}{|l|}{ Polygonum } \\
\hline hydropiperoides & - & - & - & - & - & - & - & + & + & - & - \\
\hline Polygonum lapathifolium & - & - & - & - & - & - & - & + & + & - & - \\
\hline \multicolumn{12}{|l|}{ Polygonum } \\
\hline pensylvanicum & - & - & - & - & - & - & - & + & + & - & - \\
\hline Polygonum persicaria & - & - & - & - & - & - & - & + & + & - & - \\
\hline Polygonum punctatum & - & - & - & - & - & - & - & + & + & - & - \\
\hline Polygonum setaceum & - & - & - & - & - & - & - & + & + & - & - \\
\hline Polygonum virginianum & - & - & - & - & + & + & - & - & - & - & - \\
\hline \multicolumn{12}{|l|}{ Polypodium } \\
\hline polypodioides & - & + & + & + & + & + & + & - & + & + & - \\
\hline Polypogon monspeliensis & - & - & - & - & - & - & - & + & - & - & - \\
\hline Polypremum procumbens & - & - & + & + & + & + & + & + & - & - & - \\
\hline \multicolumn{12}{|l|}{ Polystichum } \\
\hline acrostichoides & - & - & - & - & + & + & - & - & - & - & - \\
\hline Poncirus trifoliata & - & - & - & - & - & - & - & + & - & - & - \\
\hline Populus deltoides & - & - & - & - & - & - & - & + & - & - & - \\
\hline Portulaca oleracea & - & - & - & - & - & - & - & + & - & - & - \\
\hline Portulaca pilosa & - & - & - & - & - & - & - & + & - & - & - \\
\hline \multicolumn{12}{|l|}{ Potamogeton } \\
\hline diversifolius & - & - & - & - & - & - & - & - & - & + & - \\
\hline Potamogeton nodosus & - & - & - & - & - & - & - & - & - & + & - \\
\hline Potamogeton pulcher & - & - & - & - & - & - & - & - & - & + & - \\
\hline Prenanthes barbata & - & - & - & - & + & + & - & - & - & - & - \\
\hline Proserpinaca palustris & + & + & + & - & - & - & - & - & + & - & - \\
\hline Proserpinaca pectinata & + & + & + & - & - & - & - & - & - & - & - \\
\hline Prunella vulgaris & - & - & - & - & - & - & - & + & - & - & - \\
\hline Prunus americana & - & - & - & + & + & + & + & - & - & - & - \\
\hline Prunus angustifolia & - & - & - & - & - & - & - & + & - & - & - \\
\hline Prunus caroliniana & - & - & - & - & + & - & - & - & - & - & - \\
\hline Prunus mexicana & - & - & - & + & + & + & + & - & - & - & - \\
\hline Prunus persica & - & - & - & - & - & - & - & + & - & - & - \\
\hline Prunus serotina & - & - & - & + & + & + & + & - & - & - & - \\
\hline Prunus umbellata & - & - & + & + & - & - & - & - & - & - & - \\
\hline Psilocarya nitens & - & - & + & - & - & - & - & - & + & - & - \\
\hline Ptelea trifoliata & - & - & - & - & + & - & - & - & - & - & - \\
\hline
\end{tabular}


Table C2. Plant Species and vegetation type(s) where found in the Limited Use Area, Vernon Ranger District, Kisatchie National Forest, Louisiana--Continued

Species bog baygall savan sandy riparian mix longleaf dist swamp water Notes

Pteridium aquilinum

Pteroglossaspis ecristata

Ptilimnium capillaceum

Ptilimnium costatum

Ptilimnium nuttallii

Ptilimnium $x$ texense

Pueraria montana

var. lobata

Pycnanthemum

albescens

Pycnanthemum

tenuifolium

Pyracantha coccinea

Pyrrhopappus

carolinianus

Pyrus communis

Quercus alba

Quercus falcata

var falcata

Quercus hemisphaerica

Quercus incana

Quercus laurifolia

Quercus lyrata

Quercus margarettiae

Quercus marilandica

Quercus michauxii

Quercus muhlenbergii

Quercus nigra

Quercus pagoda

Quercus phellos

Quercus shumardii

Quercus similis

Quercus stellata

Quercus velutina

Quercus virginiana

Ranunculus abortivus

Ranunculus fascicularis

Ranunculus marginatus

Ranunculus muricatus

Ranunculus parviflorus

Ranunculus platensis

Ranunculus pusillus

Ranunculus sardous

Ranunculus scleratus

Ratibida pinnata 
Table C2. Plant Species and vegetation type(s) where found in the Limited Use Area, Vernon Ranger District, Kisatchie National Forest, Louisiana--Continued

\begin{tabular}{|c|c|c|c|c|c|c|c|c|c|c|c|}
\hline Species & bo & bay & savan & sandy & riparian & $\operatorname{mix}$ & lengleaf & dis & swamp & water & Notes \\
\hline Rhamnus caroliniana & - & - & - & - & + & + & - & - & - & - & - \\
\hline Rhexia alifanus & + & + & + & - & - & - & - & - & - & - & - \\
\hline Rhexia lutea & + & + & + & - & - & - & - & - & - & - & - \\
\hline Rhexia mariana & + & + & + & - & - & + & + & - & + & - & - \\
\hline Rhexia petiolata & + & + & + & - & - & - & - & - & - & - & - \\
\hline Rhexia virginica & + & + & + & - & - & - & - & - & + & - & - \\
\hline Rhododendron canescens & + & + & + & - & + & + & - & - & - & - & - \\
\hline Rhododendron coryi & + & + & + & - & - & - & - & - & - & - & - \\
\hline \multicolumn{12}{|l|}{ Rhododendron } \\
\hline oblongifolium & + & + & + & - & - & - & - & - & - & - & - \\
\hline Rhododendron viscosum & + & + & + & - & - & - & - & - & - & - & - \\
\hline Rhus aromatica & - & - & - & - & - & - & - & - & - & - & * \\
\hline Rhus copallinum & - & - & + & + & + & + & + & - & - & - & - \\
\hline Rhynchosia difformis & - & - & + & + & - & + & + & - & - & - & - \\
\hline Rhynchosia latifolia & - & - & + & + & - & + & + & - & - & - & - \\
\hline Rhynchosia reniformis & - & - & + & + & - & + & + & - & - & - & - \\
\hline Rhynchosia tomentosa & - & - & + & + & - & + & + & - & - & - & - \\
\hline Rhynchospora caduca & + & + & + & - & - & + & + & + & + & - & - \\
\hline Rhynchospora capitellata & + & + & + & - & - & + & + & + & + & - & - \\
\hline \multicolumn{12}{|l|}{ Rhynchospora } \\
\hline cephalantha & + & + & + & - & - & + & + & + & + & - & - \\
\hline \multicolumn{12}{|l|}{ Rhynchospora } \\
\hline chalarocephala & + & + & + & - & - & + & + & + & + & - & - \\
\hline Rhynchospora corniculata & + & + & + & - & - & + & + & + & + & - & - \\
\hline Rhynchospora debilis & + & + & + & - & - & + & + & + & + & - & - \\
\hline Rhynchospora elliottii & + & + & + & - & - & + & + & + & + & - & - \\
\hline Rhynchospora fascicularis & + & + & + & - & - & + & + & + & + & - & - \\
\hline Rhynchospora filifolia & + & + & + & - & - & + & + & + & + & - & - \\
\hline Rhynchospora globularis & + & + & + & - & - & + & + & + & + & - & - \\
\hline Rhynchospora glomerata & + & + & + & - & - & + & + & + & + & - & - \\
\hline Rhynchospora gracilenta & + & + & + & - & - & + & + & + & + & - & - \\
\hline Rhynchospora grayi & + & + & + & - & - & + & + & + & + & - & - \\
\hline Rhynchospora harveyi & + & + & + & - & - & + & + & + & + & - & - \\
\hline Rhynchospora inexpansa & + & + & + & - & - & + & + & + & + & - & - \\
\hline Rhynchospora intermixta & + & + & + & - & - & + & + & + & + & - & - \\
\hline Rhynchospora macra & + & + & + & - & - & + & + & + & + & - & - \\
\hline \multicolumn{12}{|l|}{ Rhynchospora } \\
\hline macrostachya & + & + & + & - & - & + & + & + & + & - & - \\
\hline Rhynchospora microcarpa & + & + & + & - & - & + & + & + & + & - & - \\
\hline Rhynchospora miliacea & + & + & + & - & - & + & + & + & + & - & - \\
\hline Rhynchospora mixta & + & + & + & - & - & + & + & + & + & - & - \\
\hline Rhynchospora oligantha & + & + & + & - & - & + & + & + & + & - & - \\
\hline Rhynchospora perplexa & + & + & + & - & - & + & + & + & + & - & - \\
\hline Rhynchospora plumosa & + & + & + & - & - & + & + & + & + & - & - \\
\hline
\end{tabular}


Table C2. Plant Species and vegetation type(s) where found in the Limited Use Area, Vernon Ranger District, Kisatchie National Forest, Louisiana--Continued

Species bog baygall savan sandy riparian mix longleaf dist swamp water Notes

Rhynchospora pusilla

Rhynchospora rariflora

Richardia scabra

Robinia hispida

Robinia pseudoacacia

Rorippa sessiliflora

Rosa bracteata

Rosa laevigata

Rotala ramosior

Rubus aboriginum

Rubus argutus

Rubus flagellaris

Rubus trivialis

Rudbeckia grandiflora

Rudbeckia hirta

Rudbeckia missouriensis

Rudbeckia nitida

Rudbeckia scabrifolia

Rudbeckia subtomentosa

Ruellia caroliniensis

Ruellia humilis

Rumex crispus

Rumex hastatulus

Rumex pulcher

Sabal minor

Sabatia brachiata

Sabatia campestris

Sabatia gentianoides

Sabatia macrophylla

Sacciolepis indica

Sagina decumbens

Sagittaria calycina

Sagittaria graminea

Sagittaria latifolia

Sagittaria papillosa

Sagittaria platyphylla

Salix exigua

Salix nigra

Salvia azurea

Salvia lyrata 
Table C2. Plant Species and vegetation type(s) where found in the Limited Use Area, Vernon Ranger District, Kisatchie National Forest, Louisiana--Continued

Species bog baygall savan sandy riparian mix longleaf dist swamp water Notes

Sambucus canadensis

Samolus valerandi

ssp. parviflorus

Sanicula canadensis

Sapium sebiferum

Sarracenia alata

Sassafras albidum

Saururus cernuus

Schizachyrium scoparium

Schizachyrium tenerum

Schoenolirion croceum

Scirpus atrovirens

Scirpus cyperinus

Scirpus koilolepis

Scirpus lineatus

Scirpus molestus

Scleria baldwinii

Scleria ciliata

Scleria georgiana

Scleria oligantha

Scleria pauciflora

Scleria reticularis

Scleria triglomerata

Scoparia dulcis

Scutellaria cardiophylla

Scutellaria drummondii

Scutellaria elliptica

Scutellaria integrifolia

Scutellaria ovata

Scutellaria parvula

Sebastiana fruticosa

Selaginella apoda

Selaginella arenicola

Senecio glabellus

Senecio plattensis

Senecio tomentosus

Sesbania exaltata

Sesbania punicea

Setaria geniculata

Setaria glauca 
Table C2. Plant Species and vegetation type(s) where found in the Limited Use Area, Vernon Ranger District, Kisatchie National Forest, Louisiana--Continued

Species bog baygall savan sandy riparian

Seymeria cassinoides

Sherardia arvensis

Sida rhombifolia

Sida spinosa

Silene antirrhina

Silene gallica

Silene stellata

Silene subciliata

Silphium asteriscus

Silphium gracile

Silphium integrifolium

Silphium laciniatum

Silphium radula

Sisyrinchium albidum

Sisyrinchium

$$
\text { angustifolium }
$$

Sisyrinchium atlanticum

Sisyrinchium campestre

Sisyrinchium exile

Sisyrinchium langloisii

Sisyrinchium

$$
\text { mucronatum }
$$

Sisyrinchium rosulatum

Sisyrinchium sagittiferum

Smallanthus uvedalia

Smilax bona-nox

Smilax glauca

Smilax herbacea

Smilax hispida

Smilax laurifolia

Smilax pumila

Smilax rotundifolia

Smilax smallii

Smilax walteri

Solanum carolinense

Solanum elaeagnifolium

Solanum ptycanthum

Solanum rostratum

Solidago arguta

var. boottii

Solidago auriculata

Solidago caesia

Solidago canadensis 
Table C2. Plant Species and vegetation type(s) where found in the Limited Use Area, Vernon Ranger District, Kisatchie National Forest, Louisiana--Continued

Species bog baygall savan sandy riparian mix longleaf dist swamp water Notes

Solidago ludoviciana

Solidago nitida

Solidago odora

Solidago patula

Solidago patula

var. strictula

Solidago petiolaris

Solidago radula

Solidago rugosa

ssp. aspera

Solidago rugosa

ssp. rugosa

Solidago speciosa

Solidago tortifolia

Solidago ulmifolia

Soliva sessilis

Sonchus asper

Sonchus oleraceus

Sorghastrum elliottii

Sorghastrum nutans

Sorghum bicolor

Sorghum halepense

Sparganium americanum

Spermolepis divaricata

Spermolepis echinata

Spermolepis inermis

Sphenoclea zeylandica

Sphenopholis filiformis

Sphenopholis longiflora

Sphenopholis nitida

Sphenopholis obtusata

Spigelia marilandica

Spiranthes cernua

Spiranthes lacera

Spiranthes laciniata

Spiranthes longilabris

Spiranthes odorata

Spiranthes praecox

Spiranthes tuberosa

Spiranthes vernalis

Sporobolus asper

Sporobolus clandestinus

Sporobolus indicus 
Table C2. Plant Species and vegetation type(s) where found in the Limited Use Area, Vernon Ranger District, Kisatchie National Forest, Louisiana--Continued

Species bog baygall savan sandy riparian mix longleaf dist swamp water Notes

Sporobolus junceus

Sporobolus neglectus

Sporobolus vaginiflorus

Stachys agraria

Stellaria media

Stenanthium gramineum

Stenotaphrum

secundatum

Stillingia sylvatica

Stipa avenacea

Strophostyles leiosperma

Strophostyles umbellata

Stylisma aquatica

Stylisma humistrata

Stylisma patens

Stylisma pickeringii var. pattersonii

Stylisma villosa

Stylodon carneus

Stylosanthes biflora

Styrax americana

Styrax grandifolia

Symplocos tinctoria

Talinum calycinum

Taxodium distichum

Tephrosia florida

Tephrosia

onobrychioides

Tephrosia virginiana

Tetragonotheca

ludoviciana

Teucrium canadense

Thalictrum dasycarpum

Thelypteris

hexagonoptera

Thelypteris kunthii

Tilia americana

var. americana

Tillandsia usneoides

Tipularia discolor

Torilis arvensis

Toxicodendron pubescens

Toxicodendron radicans

Toxicodendron vernix

Trachelospermum difforme - 
Table C2. Plant Species and vegetation type(s) where found in the Limited Use Area, Vernon Ranger District, Kisatchie National Forest, Louisiana--Continued

Species bog baygall savan sandy riparian mix longleaf dist swamp water Notes

Tradescantia hirsutiflora

Tradescantia occidentalis

Tradescantia ohioensis

Tradescantia paludosa

Tradescantia reverchonii

Tragia betonicifolia

Tragia cordata

Tragia smallii

Tragia urens

Tragia urticifolia

Triadenum tubulosum

Triadenum virginicum

Triadenum walteri

Trichostema dichotomum

Trichostema setaceum

Tridens ambiguus

Tridens chapmanii

Tridens flavus

Tridens strictus

Trifolium campestre

Trifolium carolinianum

Trifolium dubium

Trifolium incarnatum

Trifolium lappaceum

Trifolium pratense

Trifolium repens

Trifolium resupinatum

Trifolium vesiculosum

Trillium gracile

Trillium ludovicianum

Triodanis biflora

Triodanis perfoliata

Triplasis purpurea

Tripsacum dactyloides

Trisetum interruptum

Triticum aestivum

Typha angustifolia

Typha domingensis

Typha latifolia

Ulmus alata

\begin{tabular}{|c|c|c|c|c|c|c|}
\hline+ & + & + & + & - & - & - \\
\hline+ & + & + & + & - & - & - \\
\hline+ & + & + & + & - & - & - \\
\hline+ & + & + & + & - & - & - \\
\hline+ & + & + & + & - & - & - \\
\hline+ & - & + & + & - & - & - \\
\hline - & + & - & - & - & - & - \\
\hline+ & - & + & + & - & - & - \\
\hline+ & - & + & + & - & - & - \\
\hline+ & - & + & + & - & - & - \\
\hline - & - & - & - & - & - & - \\
\hline - & + & - & - & - & + & - \\
\hline - & + & - & - & - & + & - \\
\hline+ & - & + & + & - & - & - \\
\hline+ & - & + & + & - & - & - \\
\hline- & - & - & - & - & - & - \\
\hline+ & - & - & + & - & - & - \\
\hline+ & + & + & + & - & - & - \\
\hline- & + & + & - & - & - & - \\
\hline - & - & - & - & + & - & - \\
\hline - & - & - & - & + & - & - \\
\hline- & - & - & - & + & - & - \\
\hline - & - & - & - & + & - & - \\
\hline- & - & - & - & + & - & - \\
\hline - & - & - & - & + & - & - \\
\hline- & - & - & - & + & - & - \\
\hline- & - & - & - & + & - & - \\
\hline - & - & - & - & + & - & - \\
\hline- & + & - & - & - & - & - \\
\hline - & + & - & - & - & - & - \\
\hline - & + & + & - & + & - & - \\
\hline- & + & + & - & + & - & - \\
\hline+ & - & - & - & - & - & - \\
\hline- & - & - & - & - & - & - \\
\hline- & - & - & - & + & - & - \\
\hline - & - & - & - & + & - & - \\
\hline- & - & - & - & - & + & + \\
\hline - & - & - & - & - & + & + \\
\hline- & - & - & - & - & + & + \\
\hline t & + & + & + & - & - & - \\
\hline
\end{tabular}


Table C2. Plant Species and vegetation type(s) where found in the Limited Use Area, Vernon Ranger District, Kisatchie National Forest, Louisiana--Continued

\begin{tabular}{|c|c|c|c|c|c|c|c|c|c|c|c|}
\hline Species & bog & baygall & savan. & sandy & riparian & $\operatorname{mix}$ & longleaf & dis & swamp & water & Notes \\
\hline Ulmus americana & - & - & - & - & + & + & - & - & - & - & - \\
\hline Ulmus rubra & - & - & - & - & + & + & - & - & - & - & - \\
\hline Utricularia cornuta & + & + & + & - & - & - & - & - & - & - & - \\
\hline Utricularia foliosa & - & - & - & - & - & - & - & - & - & + & - \\
\hline Utricularia gibba & - & - & - & - & - & - & - & - & - & + & - \\
\hline Utricularia inflata & - & - & - & - & - & - & - & - & - & + & - \\
\hline Utricularia juncea & + & + & + & - & - & - & - & - & - & - & - \\
\hline Utricularia radiata & - & - & - & - & - & - & - & - & - & + & - \\
\hline Utricularia subulata & + & + & + & - & - & - & - & - & - & - & - \\
\hline Uvularia sessilifolia & - & - & - & - & - & - & - & - & - & - & $* *$ \\
\hline Vaccinium arboreum & - & + & + & + & + & + & + & - & - & - & - \\
\hline Vaccinium corymbosum & - & + & + & + & + & + & + & - & - & - & - \\
\hline Vaccinium elliottii & - & + & + & + & + & + & + & - & - & - & - \\
\hline Vaccinium fuscatum & + & + & + & - & - & - & - & - & - & - & - \\
\hline Vaccinium stamineum & - & - & - & + & - & + & + & - & - & - & - \\
\hline Vaccinium virgatum & - & + & + & + & + & + & + & - & - & - & - \\
\hline Valerianella radiata & - & - & - & - & - & - & - & + & - & - & - \\
\hline Verbascum thapsum & - & - & - & - & - & - & - & + & - & - & - \\
\hline Verbena bonariensis & - & - & - & - & - & - & - & + & - & - & - \\
\hline Verbena brasiliensis & - & - & - & - & - & - & - & + & - & - & - \\
\hline Verbena halei & - & - & - & - & - & - & - & + & - & - & - \\
\hline Verbena montevidensis & - & - & - & - & - & - & - & + & - & - & - \\
\hline Verbena urticifolia & - & - & - & - & - & - & - & + & - & - & - \\
\hline Verbena xutha & - & - & - & - & - & - & - & + & - & - & - \\
\hline Verbesina alternifolia & - & - & + & + & + & + & + & - & - & - & - \\
\hline Verbesina helianthoides & - & - & + & + & + & + & + & - & - & - & - \\
\hline Verbesina virginica & - & - & + & + & + & + & + & - & - & - & - \\
\hline Verbesina walteri & - & - & + & + & + & + & + & - & - & - & - \\
\hline Vernicia fordii & - & - & - & - & - & - & - & + & - & - & - \\
\hline Vernonia baldwinii & - & - & - & + & + & + & + & - & - & - & - \\
\hline Vernonia gigantea & - & - & - & - & + & - & - & - & + & - & - \\
\hline Vernonia missurica & - & - & + & + & - & + & + & - & - & - & - \\
\hline Vernonia texana & - & - & + & + & - & + & + & - & - & - & - \\
\hline Vernonia $\mathrm{x}$ peralta & - & - & + & + & - & + & + & - & - & - & - \\
\hline Veronica arvensis & - & - & - & - & - & - & - & + & - & - & - \\
\hline Veronica peregrina & - & - & - & - & - & - & - & + & - & - & - \\
\hline Veronica persica & - & - & - & - & - & - & - & + & - & - & - \\
\hline Vetiveria zizanioides & - & - & - & - & - & - & - & + & - & - & - \\
\hline Viburnum acerifolium & - & - & - & - & + & + & - & - & - & - & . \\
\hline
\end{tabular}


Table C2. Plant Species and vegetation type(s) where found in the Limited Use Area, Vernon Ranger District, Kisatchie National Forest, Louisiana--Continued

Species. bog baygall savan sandy riparian mix longleaf dist swamp water Notes

Viburnum dentatum var. dentatum

Viburnum dentatum var. scabrellum

Viburnum nudum var. cassinoides

Viburnum nudum var. nudum

Viburnum prunifolium

Viburnum rufidulum

Vicia caroliniana

Vicia ludoviciana

Vicia minutiflora

Vicia sativa

Vicia villosa

Vinca major

Viola bicolor

Viola esculenta

Viola lanceolata

Viola langloisii

Viola palmata var. palmata

Viola palmata var. triloba

Viola pedata

Viola pratincola

Viola primulifolia

Viola sororia

Viola walteri

Vitis aestivalis

Vitis cinera

Vitis lincecunii

Vitis rotundifolia

Vulpia myuros

Vulpia octoflora

Wahlenbergia marginata

Wisteria frutescens

Wisteria sinensis

Woodwardia areolata

Woodwardia virginica

Xanthium strumarium

Xanthorhiza

simplicissima 
Table C2. Plant Species and vegetation type(s) where found in the Limited Use Area, Vernon Ranger District, Kisatchie National Forest, Louisiana--Continued

Species bog baygall savan sandy riparian mix longleaf dist_swamp water Notes

Xyris ambigua

Xyris baldwiniana

Xyris caroliniana

Xyris difformis

var curtisii+

Xyris difformis

var difformist

Xyris drummondii

Xyris jupicai

Xyris laxifolia

var. iridifolia +

Xyris louisianica

Xyris platylepis

Xyris scabrifolia

Xyris stricta

Xyris torta

Youngia japonica

Yucca aloifolia

Yucca louisianensis

Zanthoxylum

clava-herculis

Zea mays

Zephyranthes candida

Zigadenus densus

Zizaniopsis miliacea

Zizia aurea

Zomia bracteata

$\begin{array}{lllllllllll}+ & + & + & - & - & - & - & - & + & - & - \\ + & + & + & - & - & - & - & - & + & - & - \\ + & + & + & - & - & - & - & - & + & - & - \\ + & + & - & - & - & - & - & + & - & - \\ + & + & - & - & - & - & - & + & - & - & - \\ + & + & + & - & - & - & - & - & + & - & - \\ + & + & + & - & - & - & - & - & + & - & - \\ & & & & & & & & & & - \\ + & + & - & - & - & - & - & + & - & - & - \\ + & + & + & - & - & - & - & - & + & - & - \\ + & + & + & - & - & - & - & - & + & - & - \\ + & + & + & - & - & - & - & - & + & - & - \\ + & + & + & - & - & - & - & - & - & - & - \\ + & + & + & - & - & - & - & - & + & - & - \\ - & - & - & - & - & - & - & + & - & - & - \\ - & - & - & - & - & - & - & + & - & - & - \\ - & - & - & + & - & + & + & - & - & - & - \\ & & & - & - & - & - & - & - & - & * \\ - & - & - & - & - & - & - & - & - & - & - \\ - & - & - & - & - & - & - & + & - & - & - \\ - & - & - & - & - & - & - & + & - & - & - \\ + & + & + & - & - & - & - & - & - & - & - \\ - & - & - & - & - & - & - & - & + & + & - \\ - & - & - & - & + & + & - & - & - & - & - \\ - & - & - & - & - & - & - & \pm & - & - & -\end{array}$


Table C3. Rare and Endangered Species, with State and Global Ranking, from Limited Use Area, Vernon Ranger District, Kisatchie National Forest, LA (K), or Fort Polk (F), or Vernon Parish (V)

Scientific name

AMSONIA LUDOVICIANA

BURMANNIA BIFLORA

CALOPOGON BARBATUS

CALOPOGON PALLIDUS

CAREX MICRODONTA

CAREX TENAX

CROTON ARGYRANTHEMUS

CYPERUS GRAYIOIDES

CYPRIPEDIUM KENTUCKIENSE

ECHINACEA PURPUREA

ERIOGONUM LONGIFOLIUM

GALIUM VIRGATUM

HELIOTROPIUM TENELLUM

INDIGOFERA MINIATA

VAR. LEPTOSEPHALA

LACHNOCAULON DIGYNUM

MARSHALLIA TRINERVIA

OROBANCHE UNIFLORA

PANICUM FLEXILE

PANICUM TENERUM

PLATANTHERA BLEPHARIGLOTTIS

PLATANTHERA INTEGRA

PRENANTHES BARBATA

PSILOCARYA NITENS

RHYNCHOSPORA MACRA

RHYNCHOSPORA MILIACEA

RUDBECKIA MISSOURIENSIS

RUDBECKIA SCABRIFOLIA

SABATIA MACROPHYLLA

SCUTELLARIA CARDIOPHYLLA

SELAGINELLA ARENICOLA

SILENE SUBCILIATA

TETRAGONOTHECA LUDOVICIANA

UVULARIA SESSILIFOLIA

XANTHORHIZA SIMPLICISSIMA

XYRIS DRUMMONDII

XYRIS SCABRIFOLIA

XYRIS STRICTA

ZIGADENUS DENSUS

ZORNIA BRACTEATA
STATE

S3

S2

S1

S1S2

$\mathrm{S} 2$

S2

S2

S2

S1

S1S2

S2

$\mathrm{S} 1$

$\mathrm{S} 2$

S1

S3

S1

S1

S1?

S1

S1

S2S3

S2

$\mathrm{S} 2 \mathrm{~S} 3$

S2

S2

S1S2

$\mathrm{S} 2$

$\mathrm{S} 2 \mathrm{~S} 3$

S2

S2

S1

S2

S2

S1

S3

S2

S1

S2

S2
GLOBAI

G3

G4G5

G5?

G4G5

G4

G5

G5

G3G4

G3

G4

G4

G5

G5

G5

G3

G3

G5

G4G5

G4

G4G5

G4

G2G3

G4

G3G4

G5

G4G5

G2

G4G5

G3G4

G4T4

G3

G4

G5

G5

G3

G3

G3G4

G5

G5
IOCATION

$\mathrm{V}$

K

K

K

F

V

V

F

F

F

$\mathrm{V}$

F

F

V

K

F

$\mathrm{F}$

F

K

F

K

V

V

K

F

F

K

K

V

V

V

F

F

F

K

K

K

K

V 
Table C3. Rare and Endangered Species, with State and Global Ranking, from Limited Use Area, Vernon Ranger District, Kisatchie National Forest, LA (K), or Fort Polk (F), or Vernon Parish (V)--Continued

\title{
EXPLANTION OF CODES
}

\author{
State (Louisiana) Rankings
}

S1 = Critically imperiled in Louisiana because of extreme rarity ( 5 or fewer known extant populations) or because of some factor(s) making it especially vulnerable to extirpation.

S2 = Imperiled in Louisiana because of rarity ( 6 to 20 known extant populations) or because of some factor(s) making it very vulnerable to extirpation.

S3 = Rare and local throughout the state or found locally (even abundantly at some of its locations) in a restricted region of the state, or because of other factors making it vulnerable to extirpation ( 21 to 100 known extant populations.

\section{Global Rankings}

G2 = Imperiled globally because of rarity (6 to 20 known extant populations) or because of some factor(s) making it very vulnerable to extinction throughout its range.

G3 = Either very rare and local throughout its range or found locally (even abundantly at some of its locations) in a restricted range (e.g., a single physiographic region) or because of other factors making it vulnerable to extinction throughout its range ( 21 to 100 known extant populations).

G4 = Apparently secure globally, though it may be quite rare in parts of its range, especially at the periphery (1001000 known extant populations).

G5 = Demonstrably secure globally, although it may be quite rare in parts of its range, especially at the periphery (1000+ known extant populations).

\section{Location}

$\mathrm{K}=$ Kisatchie National Forest Limited Use Area.

$\mathrm{F}=$ Fort Polk

$\mathrm{V}=$ Vernon Parish. 
Table C4. Plant Species reported only from Riparian Vegetation in the Limited Use Area, Vernon Ranger District, Kisatchie National Forest, Louisina, including Scenic Streams (Whiskey Chitto and Sixmile Creeks)

Species

Acer barbatum

Acer saccharum

Agrostis perennans

Antennaria parlinii ssp. fallax

Apios americana

Brachyelytrum erectum

Bromus pubescens

Chasmanthium latifolium

Cynoglossum virginianum

Danthonia spicata

Desmodium nudiflorum

Desmodium pauciflorum

Dicliptera brachiata

Ilex ambigua:

Listera australis

Lithospermum tuberosum

Luzula bulbosa

Luzula campestris

Luzula echinata

Malaxis unifolia

Marshallia trinervia

Prunus caroliniana

Ptelea trifoliata

Sebastiana fruticosa

Spigelia marilandica

Thalictrum dasycarpum

Tragia cordata

Trillium gracile

Trillium ludovicianum 